\title{
Економікатадержава
}

\section{Редакційна колегія}

Федоренко Валентин Григорович, головний редактор, член Спілки ректорів Європи, член національної спілки журналістів України, перший віце-президент Спілки будівельників України, професор кафедри теоретичної та прикладної економіки ІПК $\Delta$ СЗУ, $А$-р екон. наук, почесний доктор Одеськоїдержавної академії будівництва та архітектури, професор, Заслужений діяч науки і техніки України, академік УАН

Федоренко Станіслав Валентинович, заступник головного редактора, доцент кафедри охорони праці і навколишнього середовища КНУБА, академік академії будівництва України, к.т.н., доцент

Саввов Іван Антонович, заступник головного редактора, Член ради директорів, Оксфордський Академічний Союз

Кучеренко Ганна Борисівна, відповідальний секретар

Амоша Олександр Іванович, директор інституту Економіки промисловості НАН України, А-р екон. наук, професор, академік НАН України

Андрощук Генадій Олександрович, головний консультант Верховної Ради України, к-т екон. наук, доцент

Андрющенко Катерина Анатолї̈вна, професор кафедри економіки підприємств $\triangle \mathrm{BH}$ "Київський національний економічний університет імені Вадима Гетьмана», доктор економічних наук, Відмінник освіти України

Бакуменко Валерій Данилович, проректор з наукової роботи Академії муніципального управління, А-р наук з державного управління, професор

Бандур Семен Іванович, професор кафедри управління персоналом та економіки праці IПК АСЗУ, А-р екон. наук, професор

Бендасюк Олег Олександрович, головний спеціаліст департаменту атестації кадрів вищої кваліфікації МОН України, А-р екон. наук

Войтович Радмила Василівна, в. о ректора ІПК АС.ЗУ, А-р наук з державного управління, професор

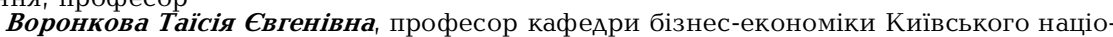
нального університету технологій та дизайну, к-т екон. наук

Воротін Валерій $\boldsymbol{G}_{\boldsymbol{B}}$ енович, заступник директора Національного інституту стратегічних досліджень, А-р наук з державного управління, професор

Гайдуцький Андрій Павлович, заступник керівника управління платіжних систем УКР СІБ банка, А-р екон. наук

Гайдуцький Павло Іванович, Радник Президента України, А-р екон. наук, професор, Заслужений діяч науки і техніки України

Грищенко Іван Михайлович, ректор Київського національного університету технологій та дизайну, А-р екон. наук, професор, академік НАПН України, Заслужений працівник освіти України

Гудзинський Олексій Дмитрович, професор кафедри менеджменту і маркетингу ІПК АСЗУ, А-р екон. наук, професор

Аацій Олександр Іванович, А-р екон. наук, професор, Заслужений працівник освіти України

Денисенко Микола Павлович, професор кафедри Київського національного універДенисенко Микола Павлович, професор кафедри Киівського націон
ситету технологій та дизайну, академік УТА, А-р екон. наук, професор

Коздовський Сергій Володимирович, професор кафедри міжнародних економічних відносин Аонецького національного університету ім. В. Стуса (м. Вінниця), А-р екон. наук, професор

Криклій Артур Станиславович, завідувач кафедри фінансів Хмельницького економічного університету, доктор економічних наук, професор, дійсний член АЕН України

Кузьмін Олег $\boldsymbol{C}_{\boldsymbol{B}}$ генович, директор навчально-наукового інституту економіки і менеджменту Національного університету "Аьвівська політехніка", А-р екон. наук, професор, Заслужений працівник народної освіти України

Куліков Петро Мусійович, ректор КНУБА, А-р екон. наук, професор, лауреат 2х державних премій в галузі науки та техніки, Заслужений працівник освіти України

Курко Микола Несторович, ректор МАУП, АОктор юридичних наук, професор, акаАемік Акалемії наук Вищої школи України, Заслужений юрист України

Кучменко Еліонора Миколаївна, професор кафедри соціології та соціальногуманітарних Аисциплін ІПК АСЗУ, Аоктор історичних наук, професор

Маршавін Юрій Миколайович, професор кафедри управління персоналом та економіки праці КНЕУ, А-р екон. наук, професор, Заслужений працівник освіти України Мігус Ірина Петрівна, головний науковий співробітник Українського науково-дослідного інституту цивільного захисту, А-р екон. наук, професор

Міщенко Катерина Семенівна, Аоцент кафедри публічного управління та адмініст-

рування ІПК $\triangle$ СЗУ,кандидат наук з державного управління, доцент

Могильний Олексій Миколайович, А-р екон. наук, професор, IПК АСЗУ

Могильний Олексій Миколайович, А-р екон. наук, професор, IПК
Момир Ажурович, президент Академії наук та мистецтв Чорногорії

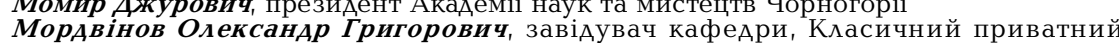
Мордвінов Олександр Гриторович, Завідувач кафеАри, КАасичний
університет ( м. Запоріжжя), А-р наук з державного управління, професор

Ольшанська Олександра Володимирівна, декан факультету економіки та бізнесу Киї-

вського національного університету технологій та дизайну, А-р екон. наук, професор

Онищенко Володимир Олександрович, ректор Полтавського національного

технічного університету, А-р екон. наук, професор

Осадча Наталія Вікторівна, А-р екон. наук, професор

Патика Наталія Іванівна, проректор 3 науково-педагогічної роботи ІПК АСЗУ,

к-т екон. наук, Аоцент

Пясківська Марія Станіславівна, начальник відділу статистики та прогнозування Київського обласного центру зайнятості

Радиш Ярослав Федорович, А-р наук з державного управління, професор Розпутенко Іван Васильович, А-р наук з державного управління, професор Саблук Петро Трохимович, Почеснии директор ННЦ "Інститут аграрної економіки", А-р екон. наук, професор, академік УААН, Заслужений діяч науки і техніки України Седих Юрій Іванович, Президент Товариства Аружби «Україна - Болгарія», Член Української Ради Миру, академік, доктор філософії, Почесний доктор права, професор Тимошенко Іван Іванович, ректор Європейського університету, професор

Чапка Мирослав, ректор Вищої школи економіки та адміністращії в м. Битом (Польща),

А-р екон. наук, професор, академік Академії економічних наук України

Черкасов Андрій Володимирович, завідувач кафедри управління персоналом та економіки праці IПК АСЗУ, А-р екон. наук, АОцент

Чорна Людмила Олександрівна, завідувач кафедри фінансів оподаткування і підприємництва Вінницького інституту конструювання одягу та підприємництва, А-р екон. наук, професор

Шаров Юрій Павлович, перший заступник директора АРІАУ НААУ при Президентові України, А-р наук з державного управління, профессор

Шиян Амитро Вікторович, завідувач кафедри економіки підприємства та менеджменту Харківського національного економічного університету імені Семена Кузнеця А-р екон. наук, професор
Науково-практичний журнал

листопад 2018

Журнал засновано у січні 2003 року.

Виходить щомісяця.

Журнал включено до переліку наукових фахових видань Украӥни,

в яких можуть публікуватися

результати дисертаційних робіт на здобуттл наукових ступенів

доктора і кандидата наук 3 ЕКОНОМІКИ

(постанова президї ВАК Украӥни від 27 травня 2009 р. № 1-05/2, наказ Міністерства освіти інауки України № 1081 від 29.09.2014 р.)

\section{ІНАЕКСАЦІЯ ВИААННЯ В НАУКО- МЕТРИЧНИХ БАЗАХ:}

- SIS;

- Google Scholar.

Свідоцтво КВ № 9144, від 09.09.2004 року

ISSN 2306-6806

Передплатний індекс: 01751 Аареса редакціі:

м. Київ, вул. Аорогожицька, 18, к. 29

Поштова аАреса:

04112, м. Київ, вул. Аорогожицька, 18 , к. 29

Телефон: (044) 223-26-28, 537-14-33 Телефон/факс: (044) 458-10-73

E-mail: economy 2008@ukr.net www.economy.in.ua

Засновники:

Інститут підготовки кадрів державноїслужби зайнятості Украӥни, ТОВ"Редакиіл журналу "Економіка та держаВа" Видавець: TOB "АКС Центр"

Передрукування дозволяється лише за згодою редакції.

Відповідальність за добір і викладення фактів несуть автори. Редакція не завжди поділяє позицію авторів публікацій.

Рекомендовано до друку Вченою Радою IПКАСЗУ $29.11 .18 \mathrm{p}$.

Підписано до друку 29.11.18 р.

Формат 60х84 1/8, Ум. друк. арк. 21,8. Наклад - 1000 прим. Папір крейдований, друк офсетний. Замовлення № 2911/3.

Відаруковано у ТОВ «АКС центр» м. Київ, пров. Куренівський, 17 Тел. (044) 537-14-34 


\section{У HOMEPI:}

EкOHOMika Ta gepжав

Eкономінна

наука

Лаврук В. В., Покотильська Н. В.

Економічне обгрунтування і ефективність організації території

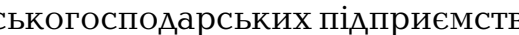

Голян В. А., Петруха С. В., Рошкевич В. Ф.

Аержавне регулювання інституціональних змін у лісовому секторі економіки

України: теоретико-методологічний контекст

Тагиев Мураg Рамиз ог., Ахундов Фараgж Таир ог., Тимощук Е. Н.

Влияние внешних факторов на динамику стоимости ценных

бумаг.....

Халатур C. М., Білич Н. C.

Фінансові важелі управління ліквідністю комерційних банків

у національній економіці України ....

Корягін М. В.

Побудова методології бухгалтерського обліку

Петренко Н. О.

Формування промислового потенціалу України: регіональний

аналіз

Мельник О. Г., Аgамів М. С., Тоgощук А. В.

Концептуальні засади реформування митної системи України в умовах

європейської інтеграції

Фуряичко А. С., Піхоцька О. М.

Причини зростання державного боргу, його управління і обслуговування, оптимізація боргової політики України

Куценко Т. Ф., Сабаgош А. О.

Базові складові ефективного управління локальною економікою

на "крихких" територіях в умовах конфлікту в Україні .

Мацук З. А.

Оцінка регіонального розподілу фінансових послуг інститутів

спільного інвестування в Україні

Руgенко М. В.

Цифровізація економіки: нові можливості та перспективи

Аазебник Ю. О.

Моніторинг якості зайнятості в Україні: запровадження європейської

системи обстеження умов праці.

Панченко Н. Г.

Механізм формування стратегічного партнерства за участю залізничного

транспорту та міжнародних стейкхолдерів

Колеснік Я. В., Криворучко А. О.

Перспективи розвитку фінансового менеджменту у сфері споживчого

та іпотечного кредитування

Руgа О. А., Маркуш К. Г.

Аепозитна політика банку та механізм її реалізації

Бровко А. І., Сорока Ю. В., Бровко С. I.

Аналіз кредитного портфеля комерційних банків України

в сучасних умовах .

Аigенко С. О., Фесюн А. С.

Теоретико-методичні засади антикризового управління

підприємствами

Гребеник К. В.

Розвиток системи бюджетного регулювання

економіки

Загребельна К. В.

Аинаміка кон'юнктури ринку нерухомості в Україні

Петрух О. А.

Інноваційний розвиток сфери охорони здоров'я

України

Корженко I. С.

Збутова діяльність підприємства-імпортера 


\section{CONTENTS:}

Lavruk V., Pokotilska N.

ECONOMIC GROUNDS AND EFFICIENCY OF ORGANIZATION OF THE AGRICULTURAL ENTERPRISES 'TERRITORY

Golyan V., Petrukha S., Roshkevych V.

STATE REGULATION OF INSTITUTIONAL CHANGES

IN THE FOREST SECTOR OF UKRAINE: THEORETICAL

AND METHODOLOGICAL CONTEXT

Tagiyev Murad Ramiz, Akhundov Faraj Tair, Tymoshchuk E.

INFLUENCE OF EXTERNAL FACTORS ON THE VALUE OF COST

OF SECURITIES

Khalatur S., Bilych N.

FINANCIAL TOOL OF LIQUIDITY MANAGEMENT OF COMMERCIAL BANKS

IN THE NATIONAL ECONOMY OF UKRAINE.

Koryagin $\mathrm{M}$.

CONSTRUCTION OF ACCOUNTING METHODOLOGY

Petrenko N.

FORMATION OF INDUSTRIAL POTENTIAL OF UKRAINE: REGIONAL

ANALYSIS

Melnyk O., Adamiv M., Todoshchuk A.

CONCEPTUAL PRINCIPLES OF REFORMING THE CUSTOMS SYSTEM OF UKRAINE

IN TERMS OF EUROPEAN INTEGRATION

Furdychko L., Pikhotska O.

CAUSES OF DEVELOPMENT OF THE PUBLIC DEBT, ITS MANAGEMENT AND SERVICE,

OPTIMIZATION OF UKRAINE'S FOREIGN POLICY

Kutsenko T., Sabadosh A.

BASIC ELEMENTS OF EFFECTIVE MANAGEMENT OF LOCAL ECONOMY ON "FRAGILE"

TERRITORIES UNDER CONFLICT CONDITIONS IN UKRAINE

Matsuk Z.

EVALUATION OF THE REGIONAL DISTRIBUTION OF THE COLLECTIVE

INVESTMENT FUNDS' FINANCIAL SERVICES IN UKRAINE.

Rudenko M.

DIGITALIZATION OF ECONOMY: NEW OPPORTUNITIES

AND PERSPECTIVES

Lazebnik Iu.

MONITORING OF THE QUALITY OF EMPLOYMENT IN UKRAINE: ESTABLISHMENT

OF EUROPEAN SYSTEM OF WORKING CONDITIONS SURVEY

Panchenko N.

MECHANISM FOR FORMING A STRATEGIC PARTNERSHIP INVOLVING RAIL

TRANSPORT AND INTERNATIONAL STAKEHOLDERS

Kolesnik Ya., Krivoruchko A.

PERSPECTIVES FOR DEVELOPMENT OF FINANCIAL MANAGEMENT IN CONSUMER

AND MORTGAGE LENDING

Ruda O., Markush K.

DEPOSIT POLICY OF THE BANK AND THE MECHANISM

OF ITS REALIZATION

Brovko L., Soroka Yu., Brovko Ye.

ANALYSIS OF THE LOAN PORTFOLIO OF UKRAINIAN COMMERCIAL BANKS

IN MODERN CONDITIONS

Didenko E., Fesiun A.

THEORETICAL AND METHODOLOGICAL PRINCIPLES

OF ANTI-CRISIS MANAGEMENT OF ENTERPRISES

Hrebenyk K.

DEVELOPMENT OF THE BUDGETARY REGULATION

OF THE ECONOMY .

Zahrebelna K.

THE DYNAMICS OF THE REAL ESTATE MARKET CONDITIONS

IN UKRAINE

Petruch O.

INNOVATIVE DEVELOPMENT OF UKRAINE'S HEALTHCARE

SECTOR

Korzhenko I.

SALES ACTIVITY OF THE IMPORTING COMPANY 
УАК 332.2:711.5:631:11

B. B. $\Lambda$ aßpyк,

д.е.н., дочент, завідувач кафедри геодезії та землеустрою,

Н.В.Покотильсъка,

к.е.н., дочент, дочент кафедри менеджменту, публічного управліннл та адмініструваннл

Подільский державний аграрно-технічний університет, м. Кам'янець-Подільсъкий

DOI: $10.32702 / 2306-6806.2018 .11 .4$

\title{
ЕКОНОМІЧНЕ ОБГРУНТУВАННЯ \\ I ЕФЕКТИВНІСТЬ ОРГАНІЗАЦІЇ ТЕРИТОРІЇ СІЛЬСЬКОГОСПОААРСЬКИХ ПІАПРИЕМСТВ
}

\author{
V. Lavruk, \\ Doctor of Economic Sciences, Associate Professor, Head of the Department of Geodesy and Land Management, \\ N. Pokotilska, \\ Ph.D. in Economics, Associate Professor, Associate Professor of the Department of Management, \\ Public management and Administration \\ State Agrarian and Engineering University in Podillia, Kamyanetz-Podilskiy
}

ECONOMIC GROUNDS AND EFFICIENCY OF ORGANIZATION OF THE AGRICULTURAL ENTERPRISES 'TERRITORY

Аосліджено проблемні питання економічного обгрунтування $і$ ефективності організації території Сільськогосподарських підприємств. ВСтановлено ефект організації території в залежності від ролі землі і використанні ї̈ вАастивостей при виробництві суспільно необхідного продуктУ, де земля виступає як просторовий базис і головний засіб виробництва та при виконанні окремих виробничих процесів, де земля є предметом праці або просторовим операційним базисом. Визначено методику розрахунку ефективності капіталовкладень на створення елементів виробничої і соціальної інфраструктури відповідного господарського рівня. Обгрунтовується вибір найкращої системи сівозмін у господарстві через використання максимального сумарного приросту чистого доходУ. ДосАідЖуютьСя питання проектУвання Сівозмін, які СтосуютьСЯ СКАадУ культур та їх розміщення по території і відносно господарськихцентрів, число і розмір сівозмін, полів та нив, організацію території та праці в землеробстві. Запропоновано показники оцінки рівня використання продуктивних властивостей земель при економічному обгрунтуванні організації Сівозмін господарств. Розроблено методику розрахунку балансу гумусу за варіантами проектованих сівозмін, яка може бути використана при економічному аналізі і порівнянні варіантів Структури посівних площ та обгрунтуванні трансформації сільськогосподарських угідь. Аоведено, що розрахунок вартості валової продукції рільництва з метою зіставлення варіантів проектування Сівозмін необхідно проводити на один і той же рівень інтенсифікації сільськогосподарського виробництва. Визначено, що за цих умов врожайність СільСькогосподарських культур як СКАадова розрахункУ вартості валової продукції буде залежати від різного розміщення культур по грунтам господарства і від попередників у сівозміні.

The problematic issues of economic substantiation and efficiency of organization of the territory of agricultural enterprises are investigated. The effect of organization of the territory depending on the role of land and the use of its properties in the production of a socially necessary product is established, where the land acts as a spatial basis and the main means of production and in the performance of individual production processes, where the land is the subject of labor or the spatial operational basis. The method of calculating the efficiency of capital investments for creation of elements of industrial and social infrastructure of the corresponding economic level is determined. The choice of the best system of crop rotation in the economy is substantiated by using the maximum total net income growth. The problems of crop rotation design are studied, which are related to the composition of crops and their placement in the territory and relative to economic centers, the number and size of crop rotation, the fields in them, the organization of territory and labor in agriculture. The proposed indicators for assessing the level of productive land properties in the economic justification organizations rotation farms. The method of calculating the humus balance for variants of projected crop rotation is developed, which can be used for economic analysis and comparison of variants of the structure of crop areas and substantiation of the transformation of agricultural lands. It is proved that the calculation of the value of gross production of arable 
land to compare the design of crop rotation should be carried out at the same level of intensification of agricultural production. Determined that under these conditions, crop yields as a component of calculating the value of gross output will depend on the placement of various crops in soils economy and their predecessors in the rotation.

Ключові слова: сільськогосподарські угіддя, земля, земельні ресурси, ефективність, організачія території, господарство, сівозміна, баланс гумусу, родючість.

Key words: agricultural land, land, land resources, efficiency, organization of territory, economy, crop rotation, bumus balance, fertility.

\section{ПОСТАНОВКА ПРОБЛЕМИ}

Організація раціонального використання сільськогосподарських земель на підприємствах передбачає вирішення великої кількості технологічних, організаційно-господарських, соціально-економічних, організаційно-територіальних та інших питань, які знаходяться між собою в тісному взаємозв'язку. Будь-яке підприємство являє собою багаторівневу динамічну систему, що знаходиться під впливом численних природних і економічних умов. Тому організація сільськогосподарського виробництва і території повинна здійснюватися на основі комплексних проектів у відповідності до науково-обгрунтованого землеустрою.

\section{АНАЛІЗ ОСТАННІХ ДОСЛІДЖЕНЬ І ПУБЛІКАЦІЙ}

Проблеми підвищення ефективності організації території сільськогосподарських підприємств та раціонального використання земель є предметом досліджень багатьох науковців. Різноманітні аспекти земельних відносин висвітлені у працях українських та зарубіжних вчених, зокрема В.Г. Андрійчука, Т.В. Анопрієнко, А.І. Бабміндри, I.К. Бистрякова [2], С.М. Волкова, B.В. Горлачука, М.М. Гуменюка [1], А.С. Ааниленка, А.С. Аобряка [5], И.М.Аороша, Т.Г.Аудара [4], П.Г. Казьміра, В.М. Кривова, О.П. Канаша [5], М.И. Малік, В.Я. Месель-Веселяка [6], А.Я. Новаковського, В.І. Нудельмана, I.А. Розумний, В.І. Семчика, П.Т. Саблука, А.Я. Сохнич, А.М. Третяка [7], М.М. Федорова [6], М.А. Хвесика й ряду інших. Проте ще велика кількість питань у цій наукові галузі залишаються невирішеними.

Але при економічному обгрунтуванні землеустрою різними авторами пропонується використовувати велику кількість показників, які в ряді випадків призводять до суперечливих рішень, що потребує подальших досліджень.

\section{ФОРМУЛЮВАННЯ ЦІЛЕЙ СТАТТІ}

Метою статті є дослідження організації території сільськогосподарських підприємств в залежність від ролі землі і використання її властивостей, економічне обгрунтування і ефективність організації території сільськогосподарських підприємств та складових економічного механізму підвищення ефективності її використання.

\section{ВИКЛАД ОСНОВНОГО МАТЕРІАЛУ ДОСЛІДЖЕННЯ}

Процес виробництва в сільськогосподарському підприємстві здійснюється перш за все в різних його сферах і може диференціюватися на окремі галузі виробництва, або їх сукупність, і самостійні виробничі процеси, операції (сівба, догляд за посівами, збирання врожаю). Кожній складової частини виробництва відповідає своя форма земельного устрою: виробництву в цілому - його землекористування; галузі або сукупності галузей - земельний масив виробничого підрозділу або сівозміна; окремому процесу - поле, робоча ділянку. Рівень виробництва визначає відповідну йому інфраструктуру (виробничу і соціальну), в якій головне місце належить засобам виробництва, нерозривно пов'язаних із землею (дороги, канали, водні споруди).

Виходячи з диференціації процесу виробництва, слід розрізняти і ефект організації території, поставивши його в залежність від ролі землі і використання її властивостей:
1) при виробництві суспільно необхідного продукту та в галузях тваринництва, де земля виступає як просторовий базис, при виробництві продукції галузей рослинництва, де земля виступає як головний засіб виробництва;

2) при виконанні окремих виробничих процесів, де земля є предметом праці або просторовим операційним базисом.

При цьому основний ефект внутрішньогосподарської організації полягає:

- при розміщенні виробничих підрозділів, господарських центрів і магістральних доріг - у зниженні щорічних витрат виробництва і різного роду втрат (під забудову, будівництво доріг та ін);

- при організації угідь і організації сівозмін - у прирості чистого доходу;

- при влаштуванні території сівозмін, багаторічних насадженні та кормових угідь — в економії витрат на виконання виробничих процесів і запобіганні втрат виробництва (за рахунок зменшення площ під поворотними смугами, залишковими трикутниками).

Відповідно до такої диференціації економічного ефекту землеустрою пропонується розраховувати ефективність капіталовкладень на створення елементів виробничої і соціальної інфраструктури відповідного господарського рівня. При трансформації угідь витрачені капіталовкладення окупаються приростами чистого доходу з освоєних або більш інтенсивно використовуваних земель, а при влаштуванні території сівозмін капіталовкладення на будівництво польових станів, доріг окупаються за рахунок економії виробничих витрат та раціонального землекористування.

Раціональне землекористування означає максимальне залучення до господарського обігу всіх земель та їх ефективне використання за основним цільовим призначенням, створення найсприятливіших умов для високої продуктивності сільськогосподарських угідь і одержання на одиницю площі максимальної кількості продукції за найменших витрат праці та коштів [2, с. 84].

Розглядаючи землекористування як складову частину екосистеми, треба виходити 3 того, що екосистема це єдиний природний комплекс, який утворений живими організмами й середовищем їх існування, в якому живі й неживі елементи, пов'язані між собою обміном речовин і енергії [3, с. 61$]$.

A тому організація території кожного окремого сільськогосподарського підприємства визначається проектами внутрігосподарського землеустрою на науковій основі, в яких формувалися заходи з забезпечення охорони земель і їх раціонального використання, підвищення економічної продуктивності грунтів та формувалися види і типи сівозмін. Питання, які вирішуються при проектуванні сівозмін в конкретному господарстві, стосуються складу культур і їх розміщення по території і відносно господарських центрів, число і розмір сівозмін, полів в них, організацію території і праці в землеробстві. 3 точки зору економіки різна організація території, що вирішує перераховані питання, впливає на вихід валової продукції землеробства — як результат відповідності біологічних особливостей рослин природним і економічним умовам господарства, і щорічні витрати, пов'язані з організацією виробництва і території.

У зв'язку з цим в якості критерію при виборі найкращої системи сівозмін в господарстві пропонується використовувати максимальний сумарний приріст чисто- 
го доходу, що отримується за різними варіантами проектних рішень:

$$
S S=\sum_{i=1}^{m} \Delta V P i-\sum_{j=1}^{\circ} \Delta Z j+\sum_{j=0+1}^{n} \Delta E Z j .
$$

де VPi - приріст вартості валової продукції землеробства по і-му фактору, який змінюється при різних варіантах введення сівозмін $(\mathrm{i}=1,2, \ldots, \mathrm{m}) ; \mathrm{Zj}$ - збільшення витрат або втрат j-го виду; EZj - економія витрат jго виду $(j=1,2 \ldots . . n)$.

При територіальній організації виробничих процесів, яка здійснюється при влаштуванні території сівозмін, земля використовується в основному як просторовий, операційний базис, а в землеробстві і як предмет праці. При виконанні виробничих процесів у сільському господарстві витрачають нафтопродукти, експлуатують сільськогосподарську техніку, витрачається праця працівників. Незважаючи на те що готового продукту при цьому не створюється (наприклад, проведення оранки, сівби, міжрядних обробок), теперішня і минула матеріалізована праця бере участь у створенні вартості цього продукту, розмір якого визначають різні властивості землі. Тому головним показником економічного обгрунтування устрою території сівозмін повинна бути економія витрат на здійснення цих процесів.

При правильній територіальній організації виробничих процесів скорочуються втрати продукції. Це відбувається внаслідок зменшення площ необробленої землі і недосіву, проведення робіт в кращі агротехнічні терміни та ін. За своїм економічним змістом дані втрати рівнозначні приростам продукції і не пов'язані 3 капітальними вкладеннями.

По-іншому йде справа з виробничою інфраструктурою, що забезпечує устрій території сівозмін (дорогами, вододжерелами, польовими станами, лісосмугами, гідротехнічними спорудами). Їх будівництво і експлуатація пов'язані з додатковими капіталовкладеннями і поточними витратами. Будучи засобами виробництва, нерозривно пов'язаними з землею, вони займають певну площу, придатну для обробітку сільськогосподарських культур, у результаті чого недоотримають значну кількість сільськогосподарської продукції.

З огляду на відношення цих елементів інфраструктури до організації виробничих процесів і роль землі, окупність капітальних витрат, необхідних для їх будівництва, здійснюється за рахунок економії витрат і запобігання втрат продукції. Аля польових доріг - це зниження транспортних витрат і скорочення втрат продукції внаслідок переущільнення грунту; для вододжерел - це економія вартості доставки води; для польових станів це зменшення витрат, пов'язаних 3 перевезенням робочої сили, переміщенням машин, інвентарю; для гідротехнічних споруд - це запобігання збитків за рахунок зростання ярів і змиву грунту; для лісосмуг - це вартість додаткової продукції, отриманої з захищеної площі.

Аодаткова продукція може бути отримана також за рахунок здійснення тих виробничих процесів, які змінюють умови зростання рослин, впливаючи на харчовий, повітряний, водний і інші режими грунтів. Ао них відносяться: агротехнічні заходи, застосування засобів захисту рослин, інтенсивних технологій вирощування культур, добрив, що позначається також на витратах виробництва і отриманні додаткового чистого доходу.

У зв'язку з тим, що у процесі виробництва сільськогосподарської продукції беруть участь різні ресурси: трудові, земля, сільськогосподарська техніка, основне завдання землеустрою полягає в тому, щоб створити найкращі умови для використання цих ресурсів і пов'язати їх організацію. Тому при проектуванні сівозмін необхідно роз рахувати показники, що характеризують ефективність використання землі, сільськогосподарської техніки і трудових ресурсів, і встановити їх роль у формуванні вартості продукції землеробства.
Відмінності природних і економічних умов господарств знаходять своє відображення в результатах і економічних показниках діяльності сільськогосподарських підприємств. Серед цих умов важливе місце займають продуктивні і територіальні властивості землі (родючість грунтів, ступінь еродованості, віддаленість земель від господарських центрів, конфігурація угідь). Аані властивості земель беруть участь в утворенні диференціальної земельної ренти за родючістю, місцем розташування та істотно впливають на ефективність додаткових вкладень грошово-матеріальних засобів і праці в процесі інтенсифікації сільськогосподарського виробництва.

Тому правильне врахування продуктивних і територіальних властивостей землі при проектуванні сівозмін сприяє підвищенню обгрунтованості проектів землеустрою. Крім цього при проектуванні сівозмін необхідно створити найкращі умови для підвищення родючості грунтів. Це забезпечить постійне зростання виробництва продукції рільництва і розширене відтворення грунтової родючості. Аия оцінки рівня використання продуктивних властивостей земель при економічному обгрунтуванні організації сівозмін господарств необхідно розрахувати такі показники: грунтів;

- баланс гумусу і витрати на відтворення родючості

- вартість валової продукції рільництва з урахуванням якості земель господарства, розміщення сівозмін і сільськогосподарських культур по ділянках різного родючості.

Територіальні властивості земель (віддаленість від господарських центрів, величина і конфігурація контурів ріллі) впливають на витрати по вирощуванню сільськогосподарських культур. Тому при економічному обгрунтуванні організації сівозмін необхідно провести розрахунок і цього показника.

У грунтах України прослідковується негативна тенденція різкого зниження рівня гумусу (щорічне зниження на 0,5-0,6 тонни 3 га). Щорічні втрати гумусу через мінералізацію та ерозію грунтів складають 32-33 млн т, приносять більше 10 млрд грн збитків. Ао цього негативу додалися процеси виснаження грунтів через інтенсивне використання орних земель при відсутності сівозмін (менше 25\% господарств дотримуються сівозмін) [7, с. 18].

Розрахунковий баланс гумусу в грунті на рік освоєння проекту внутрішньогосподарського землеустрою щодо сівозміни складається з його витрат і приходу. Якщо взяти за основу те, що витрата гумусу внаслідок інфільтрації і надходження органічної речовини з посадковим матеріалом і за рахунок продуктів життєдіяльності грунтових організмів взаємно компенсуються, то основними статтями балансу гумусу в грунті слід вважати:

- винос гумусу в процесі ерозії грунтів за рахунок стоку талих, зливових вод і дефляції;

- мінералізацію (витрати) гумусу за рахунок виносу азоту з урожаєм сільськогосподарських культур;

- надходження органічної речовини в грунт за рахунок розкладання рослинних залишків і фіксації азоту бобовими культурами;

- накопичення гумусу за рахунок внесення органічних добрив.

Розрахунок виносу гумусу в процесі ерозії виконують виходячи з обсягу незмивного або видувного грунту і процентного вмісту в ній гумусу, на підставі відповідних розробок і формул з урахуванням умов тієї чи іншої зони і типу ерозії.

При проведенні загальних розрахунків винос гумусу в процесі ерозії (Vg, т / га) можна визначити за формулою:

$\mathrm{Vg},=0,0132 * \mathrm{~g} * \mathrm{O} * \mathrm{u} * \mathrm{Ke}$,

де $\mathrm{g}$ - вміст гумусу в грунті, в частках одиниці; O обсяг поверхневого стоку, м3 / га; u - ухил водозбору, град.; Ке - коефіцієнт ерозійної небезпеки культур; 0,0132 - перетворюючий коефіцієнт.

Аля зябу Ke $=1$. При g-0,04; $\mathrm{O}=500$ м3 / га; u=3; $\mathrm{Be}=0,79$ т $/$ га. 
Загальний баланс гумусу, що складається за весь період ротації сівозміни, визначають як середньозважену величину в залежності від площ, займаних культурами в цій сівозміні. Розраховані величини балансу гумусу за різними варіантами проектованої системи сівозмін дозволять оцінювати умови відтворення родючості грунтів.

При винесенні з грунту 1 т гумусу Аля підтримки його бездефіцитного балансу необхідно внести в середньому 10 т гною. Якщо вважати, що 1 т гною коштує 600 грн, а приріст чистого доходу за рахунок дії органічних добрив становить у середньому 1100 грн, то втрата 10 т гною обійдеться господарству в 1650 грн.

Цими величинами можна користуватися при вартісній оцінці умов відтворення родючості грунтів. У таблиці показано, як можуть скластися умови відтворення родючості грунтів за двома варіантами проектованих сівозмін. Тільки за рахунок диференційованого розміщення культур за другим варіантом економиться 2 тис. т органічних добрив щорічно.

Пропонована методика може бути використана при економічному аналізі і порівнянні варіантів структури посівних площ та обгрунтуванні трансформації угідь.

\section{ВИСНОВКИ 3 ДАНОГО ДОСЛІДЖЕННЯ}

Розрахунок вартості валової продукції рільництва 3 метою зіставлення варіантів проектування сівозмін необхідно проводити на один і той же рівень інтенсифікації сільськогосподарського виробництва (однакові площі меліорації ріллі, системи добрив, насінництва, технічна оснащеність та ін.). У цьому випадку врожайність сільськогосподарських культур як складова розрахунку вартості валової продукції буде залежати від різного розміщення культур по грунтам господарства і від попередників у сівозміні.

Мітература:

1. Гуменюк М.М. Ефективність використання земель них ресурсів сільськогосподарськими підприємствами регіону/ М.М. Гуменюк // Рекультивація складних техное косистем у новому тисячолітті: ноосферний аспект: матер. Міжнар. науково-практич. конф. Аніпропетровськ. - 2012. - С. 83-88.

2. Аеякі інституціональні аспекти земельних відносин в Україні: стан та напрями вдосконалення: [наук. видання]/НАН України, РВПС України/[I.К. Бистряков, О.С. Новоторов, Т.С. Ніколаєнко та ін.]. - К., 2002. $-134 \mathrm{c}$.

3. Аругак В.М. Теоретичні та методичні основи економіки землекористування / В.М. Аругак. - К.: ЦЗРУ, $2004-129$ c.

4. Аудар Т.Г. Системному відродженню сільських територій - сталий розвиток аграрної сфери / Т.Г.Аудар// Трансформація сільського господарства та села: ювілейний збірник наукових статей / Заг. ред. Ю.Е. Губені. - $\Lambda .: \Lambda$ НАУ, 2010. - 416 с. - С. 77-85.

5. Класифікація сільськогосподарських земель як наукова передумова їх екологобезпечного використання / А.С. Аобряк, О.П. Канаш, А.І. Бабміндра, I.А. Розумний - К.: Урожай, 2007. - 464 с.

6. Розвиток земельних відносин в аграрній сфері: монографія / Федоров М.М., Месель-Веселяк В.Я., Ходаківська О.В. та ін.]; за ред. Ю.О. Аупенка, О.В. Ходаківської. - К.: ННЦ "IAE", 2016. - 432 с. сівозмін

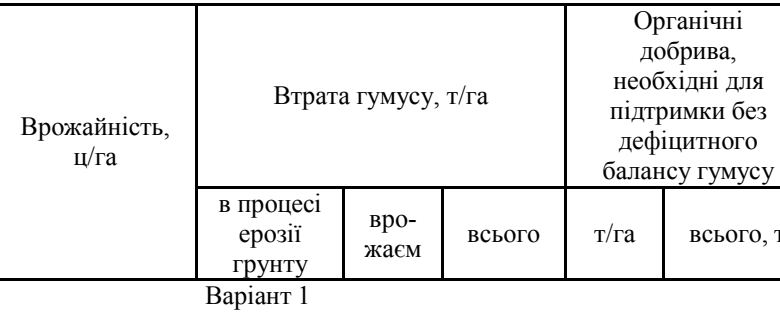

на на площі 800 га, крутизна схилу - до $3^{\circ}$

\begin{tabular}{|l|l|l|l|l|l|}
\hline- & $-1,36$ & $-3,0$ & $-4,36$ & & \\
\hline 40 & $-0,72$ & $-0,97$ & $-1,69$ & & \\
\hline 400 & $-2,28$ & $-2,77$ & $-5,05$ & & \\
\hline 40 & $-1,36$ & $-0,96$ & $-2,32$ & & \\
\hline 60 & $-0,3$ & $+0,9$ & $+0,6$ & & \\
\hline 40 & $-0,72$ & $-0,97$ & $-1,69$ & & \\
\hline 40 & $-0,84$ & $-0,05$ & $-0,89$ & & \\
\hline- & $-0,96$ & $-0,87$ & $-1,83$ & 18,3 & 14640 \\
\hline
\end{tabular}

иьохпільна сівозміна на площі 400 га, крутизна схилу - до $2^{\circ}$

\begin{tabular}{|}
\hline- & - & $-0,34$ & $-3,00$ & $-3,34$ & & \\
\hline 40 & $-0,52$ & $-0,97$ & $-1,49$ & & \\
\hline 400 & $-0,57$ & $-2,77$ & $-3,34$ & & \\
\hline 40 & $-0,34$ & $-0,96$ & $-1,3$ & & \\
\hline- & $-0,44$ & $-1,93$ & $-2,37$ & 23,7 & 9480 \\
\hline \\
чотирьохпільна сівозміна на площі 400 га, крутизна схилу - 5 \\
\hline \\
\hline 60 & $-0,6$ & $+0,9$ & $+0,3$ & & \\
\hline 40 & $-1,44$ & $-0,97$ & $-2,41$ & & \\
\hline 40 & $-1,68$ & $-0,05$ & $-1,73$ & & \\
\hline- & & & & & \\
\hline- & $-0,97$ & $+0,2$ & $-0,77$ & 7,7 & 3080 \\
\hline- & - & - & - & & 12560 \\
\hline
\end{tabular}

7. Третяк А.М. Стратегія реформування земельної політики в Україні на сучасному етапі // Землевпорядний вісник. - 2009. - № 6. - С. $12-20$.

References:

1. Humeniuk, M.M. (2012), "The efficiency of land use by agricultural enterprises of the region", Rekul'tyvatsiia skladnykh tekhnoekosystem u novomu tysiacholitti: noosfernyj aspekt. Materialy Mizhnarodnoji naukovopraktychnoji konferentsii [Reclamation complex tehnoekosystem in the new millennium: Noosphere aspect. Conference Proceedings of the International Economic Conference], Dnipropetrovsk, Ukraine, pp. 83-88.

2. Bystryakov, I.K. Novorov, O.S. and Nikolayenko, T.S. (2002), Deyaki instytutsionalni aspekty zemelnykh vidnosyn $\mathrm{v}$ Ukrayini: stan ta napryamy vdoskonalennya [Some institutional aspects of land relations in Ukraine: state and directions of improvement], NAS of Ukraine, RVPS of Ukraine, Kyiv, Ukraine.

3. Druhak, V.M. (2004), Teoretychni ta metodychni osnovy ekonomiky zemlekorystuvannya [Theoretical and methodical principles of land use economics], TZRU, Kyiv, Ukraine.

4. Dudar, T.H. (2010), "Systemic revival of rural areas sustainable development of agrarian areas", Transformatsiya silskoho hospodarstva ta sela [Transformation of agriculture and rural areas], LNAU, L'viv, Ukraine, pp. 77-85.

5. Dobryak, D.S. Kanash, O.P. Babmindra, D.I. and Rozumnyy, I.A. (2007), Klasyfikatsiya silskohospodarskykh zemel yak naukova peredumova yikh ekolohobezpechnoho vykorystannya [Classification of agricultural land as a scientific prerequisite for their ecologically safe use], Urozhay, Kyiv, Ukraine.

6. Fedorov, M.M. Mesel'-Veseliak, V.Ya. and Khodakivs'ka O. V. (2016), Rozvytok zemel'nykh vidnosyn $v$ agrarnij sferi [The development of land relations in agriculture], NNTs "IAE", Kyiv, Ukraine.

7. Tretiak, A.M. (2009), "The Strategy of Land Policy Reform in Ukraine at the Current Stage", Zemlevporyadnyy visnyk, vol. 6, pp.12-20.

Стаття надійшла до редакиії 01.11.2018 p. 


\title{
ЕКОНОМІЧНА НАУКА
}

УАK 330.837

В. А.Голян,

д.е.н., головний редактор журналу"Економіст", м. Кийь

C.B. Петруха,

к.е. н., заступник директора, Інститут післядипломної освіти

Аержавної навчально-наукової установи "Академіл фінансового управліннл", м. Киїь

В.Ф. Рошкевич, аспірант, Науково-дослідний фінансовий інститут

Аержавної навчально-наукової установи "Академія фінансового управління", м. Київ

DOI: $10.32702 / 2306-6806.2018 .11 .8$

\section{АЕРЖАВНЕ РЕГУАЮВАННЯ

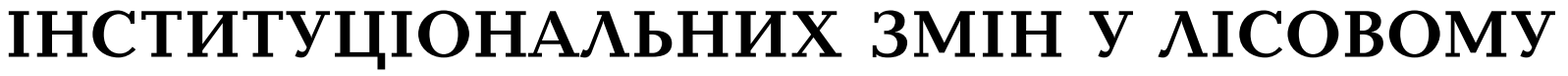 СЕКТОРІ ЕКОНОМІКИ УКРАЇНИ: ТЕОРЕТИКО- МЕТОАОАОГІЧНИЙ КОНТЕКСТ}

\author{
V. Golyan, \\ Doctor of Economics, Chief editor for "Ekonomist" journal, Kyiv \\ S. Petrukha, \\ Ph.D. in Economics, Deputy Director of the Institute of Postgraduate \\ Education of the Academy of Financial Management, Kyiv \\ V. Roshkevych, \\ Postgraduate student, Science and Research Institute of the National \\ Academic Institution "Academy of Financial Management", Kyiv
}

\section{STATE REGULATION OF INSTITUTIONAL CHANGES IN THE FOREST SECTOR OF UKRAINE: THEORETICAL AND METHODOLOGICAL CONTEXT}

ВСтановлено, що базовою методологічною передумовою державного регуАювання інституціональних змін У Аісовому секторі виступає ідентифікатор основних його СкАадників із врахуванням гал Узевих особАивостей забезпечення стійкості функціонування Аанцюга генерування,доданих вартостей у Аісовому господарстві, деревообробній, меблевій, целюлозно-паперовій, лісохімічній промисловості та зміни матеріально-речової субстанціїдеревної сировини.

Виявлено, що значним інституціональним розривом у Системі державного регулювання розвитку переробних Аанок Аісового сектора є надмірна звуженість Ажерел та методів фінансово-економічного забезпечення реалізації пріоритетів модернізації і реконструкції матеріально-технічної бази підприємств деревообробної, меблевої, целюлозно-паперової та лісохімічної промисловості, томуважливого значення набуває подальша інституціоналізація форм фінансового забезпечення розвитку переробних Аанок лісового сектора, зокрема через залучення коштів вітчизняних та іноземних приватних інвесторів (інвеСтиційних компаній, банків, трастових фондів та приватних підприємницьких Структур).

У Статті сформовано авторський підхід до структуризації напрямів державного регулювання інституціональних змін у Аісовому секторі, який виокремлює фіскальну (відміна ввізного мита на сучасне деревообробне обладнання, упорядкування Системи адміністрування Аісової ренти, надання пільГдАя виробників твердого біопалива 3 деревини), фінансово-кредитну (формування спеціалізованої установи по кредитуванню деревообробних пріоритетів, компенсація частини процентної ставки комерційним банкам за кредитні ресурси, які надаються суб'єктам переробних Аанок Аісового сектора, що впроваджують інноваційні технологї, застосування Аізингових схем для модернізації деревообробних виробництв), бюджетну (бюджетне фінансування лісоохоронних та лісогосподарських заходів, субсидування проектів утилізації неліквідної,деревини, фінансування заходів за рахунок коштів Зведеного бюджету Украӥни по 
зміні цільового призначення самозаліснених сільськогосподарських угідь), технічного регулювання (сертифікація та маркування лісової, деревообробної, целюлозно-паперової та лісохімічної продукції) скАадові, що сприятиме подоланню інвестиційного дефіциту у всіх фазах Аісопродуктового Аанцюга.

It is established that the basic methodological prerequisite for state regulation of institutional changes in the forest sector is the identifier of its main components, taking into account the sectorial features of ensuring the sustainability of the chain of value added in forestry, woodworking, furniture, pulp and paper, forest-chemical industry and changes in the material substance of wood raw materials.

It is revealed that a significant institutional gap in the system of state regulation of the development of processing units of the forest sector is an excessive narrowing of sources and methods of financial and economic support for the implementation of priorities of modernization and reconstruction of the material and technical base of enterprises of woodworking, furniture, pulp and paper and timber industry, so it is important to further institutionalize the forms of financial support for the development of processing units of the forest sector, in particular, through the attraction of funds of domestic and foreign private investors (investment companies, banks, trust funds and private businesses).

The article presents the author's approach to the structuring of the directions of state regulation of institutional changes in the forest sector. The approach allocates fiscal (the abolition of import duties on modern woodworking equipment, the streamlining of the system of administration of forest rent, the provision of benefits for biofuel producers from wood), financial and credit (the formation of a specialized institution for lending woodworking priorities, compensation of the interest rate to commercial banks for credit resources provided to the subjects of processing units of the forest sector, introducing innovative technologies, the use of leasing schemes for the modernization of woodworking industries), budget (budget financing of forest protection and forestry activities, subsidizing projects for the utilization of illiquid wood, financing activities at the expense of the Consolidated budget of Ukraine to change the purpose of agricultural lands self-deprived by wood), technical regulation (certification and labelling of forest, woodworking, pulp and paper and chemical products) components, that will contribute to overcoming the investment deficit in all phases of wood products chain.

Ключові слова: інститучіональні зміни, лісовий сектор, фіскальне регулювання, бюджет, експорт, деревообробна промисловість, необроблена деревина, публічно-приватне партнерство.

Key words: institutional changes, forest sector, fiscal regulation, budget, export, woodworking industry, raw wood, public-private partnership.

\section{ПОСТАНОВКА ПРОБЛЕМИ У ЗАГАЛЬНОМУ ВИГЛЯДІ ТАї̈ ЗВ'ЯЗОК ЗЗ ВАЖЛИВИМИ} НАУКОВИМИ ЧИ ПРАКТИЧНИМИ ЗАВДАННЯМИ

В останні роки проблеми інституціональних змін у лісовому секторі стали об'єктом дискусій як у професійному середовищі, так і в суспільстві в цілому. Це в першу чергу стосується формування інститутів, які визначають форми, методи та способи господарського освоєння лісоресурсного потенціалу та переробки деревної сировини з врахуванням домінуючих трендів у глобальній природоохоронній діяльності та міжнародному трансфері інноваційних технологій. Академік НАН України В. Геєць до таких інститутів відносить інститути, які "уособлюють у собі так звані "правила гри", тобто заходи регуляторного характеру, які мінімізують витрати ресурсів і часу для організації бізнесу, особливо інноваційного, за рахунок мотивацій, у тому числі й шляхом унормованого переходу на нові технічні та технологічні регламенти, екологічні стандарти та фітосанітарні норми, що убезпечують життєвий простір від деградації" [3, с. 10]. Саме перераховані норми для лісового сектора в умовах наявності численних інституціональних обмежень можуть забезпечити своєчасне умонтування в стратегію розвитку лісогосподарського та деревообробного виробництва поряд 3 економічними екологічних та соціальних імперативів, які упередять нарощення масштабів виснажливого використання лісоресурсного потенціалу та стимулюватимуть виробництво деревної продукції з високою доданою вартістю.

Із загостренням економічної кризи в країні збільшилася кількість проявів несанкціонованого експорту та неефективного використання лісосировини. У зв'язку з цим був запроваджений мораторій на експорт необробленої деревини, що мало посприяти зростанню ефективності поглибленої переробки деревної продукції в середині країни і забезпечити нарощення виробництва продукції з високою доданою вартістю. Однак інституціональне середовище деревообробного бізнесу потребує значних інституціональних переналаштувань щодо стратегій, підходів, механізмів та інструментів здійснення діяльності. Тому досить актуальним $є$ питання державного регулювання інституціональних змін у лісовому секторі України. Аержава як центральний інститут і центральна ланка усіх економічних відносин має відіграти вирішальну роль у формуванні сприятливого інвестиційного клімату.

У теперішніх умовах необхідно сформувати більш чітку позицію щодо масштабів інституціональних змін у лісовому секторі та відобразити її економічну інтерпретацію з поєднанням усіх державних регуляторів, що сформують систему належного контролю за господарським освоєнням ресурсів лісу та використанням ресурсно-виробничого потенціалу деревообробного виробництва. Вчені-дослідники економічних процесів у лісовій галузі важливий наголос роблять на фіскальному регулюванні лісового бізнесу, оскільки цей механізм забезпечує дотримання принципів раціональності та екологічності використання лісових ресурсів, а ще й сприяє лісовідновленню. Фіскальним регуляторам варто надати ще більшої дієвості, а саме необхідно здійснити розробку та впровадження механізму фіскального стимулювання поглибленої переробки 
деревних ресурсів та використання вторинної лісосировини.

\section{АНАЛІЗ ОСТАННІХ ДОСЛІДЖЕНЬ І ПУБЛІКАЦІЙ}

Актуальні проблеми вибору методів, способів та інструментів державного регулювання інституціональних змін у лісовому секторі піднімаються у працях В. Володимиренка (створення ефективного інструменту управління лісовим господарством) [1], А. Аейнеки (упорядкування взаємодії лісового сектора 3 іншими секторами національної економіки) [4], Т. Єгорової (впровадження в Україні інноваційної моделі розвитку лісової галузі) [5], В. Касюхнича (інструментально-методичне забезпечення системи управління лісогосподарською діяльністю) [7], I. Аицура та С. Ткачів (формування механізму фіскального регулювання лісокористування) [8], О. Мельниченка (удосконалення системи державного управління лісовим господарством) [9], В. Печуляк (державне регулювання міжгалузевих відносин у сфері лісового господарства) [10]. Проте залишається недостатньо структурованим комплекс механізмів, методів та інструментів державного регулювання інституціональних змін у лісовому секторі, які заклали б дієві стимули для переорієнтації лісогосподарських підприємств з сировинного експорту на виробництво продукції з високою доданою вартістю, а також сформували б інституціональні засади для функціонування конкурентного вітчизняного ринку деревини і введення додаткових потужностей в переробні ланки лісопродуктового ланцюга.

\section{ЦІЛІ СТАTTІ}

Метою статті є розроблення напрямів державного регулювання інституціональних змін у лісовому секторі, виходячи із структурних особливостей господарського освоєння лісоресурсного потенціалу та міжгалузевих співвідношень у лісопродуктовому ланцюзі.

\section{ВИКЛАД ОСНОВНОГО МАТЕРІАЛУ} ДОСЛІДЖЕННЯ

$\Lambda$ ісовий сектор є важливою складовою національного господарства України, оскільки, включаючи лісове господарство та деревопереробну галузь, він забезпечує трансформацію негативних екстерналій в позитивні, а також сприяє виробництву важливих для господарського комплексу виробів 3 деревини. Враховуючи багатоманітність та багатокомпонентність зв'язків в лісопродуктовому ланцюзі, формування сучасного механізму державного регулювання інституціональних змін у лісовому секторі має базуватися на диференціації методів та інструментів, виходячи з власнісної приналежності окремих його складових.

Базовою методологічною передумовою державного регулювання інституціональних змін у лісовому секторі має виступати ідентифікація основних його складових з врахуванням галузевих особливостей створення доданих вартостей та зміни матеріально-речової субстанції деревної сировини. Основними структурними елементами лісового сектора виступають: лісове господарство, деревообробна, меблева, целюлозно-паперова та лісохімічна промисловість.

В умовах командно-адміністративної економіки та централізованого управління національним господарством всі названі складові лісового сектора відзначалися розвиненою матеріально-технічною базою та відповідним інфраструктурним облаштуванням, але глибока стагнація національної економіки в 90-их роках минулого століття призвела до значного звуження виробничих потужностей у деревообробній, целюлозно-паперовій та лісохімічній промисловості. Відновлення традиційного для переробних ланок лісового комплексу потенціалу вимагає формування сучасної конструкції державного регулювання інституціональних змін, яка забезпечила б необхідні стимули для модернізації і ре- конструкції виробничо-технічної бази деревопереробних виробництв.

Найбільш деструктивні зміни відбулися в лісохімічному та целюлозно-паперовому підкомплексах, що призвело до зменшення попиту на деревину на внутрішньому ринку і змусило державні лісогосподарські підприємства експортувати деревні напівфабрикати закордон. Прикметною рисою інституціональних змін у лісовому секторі $є$ також повільне роздержавлення окремих сегментів, а також відсутність відповідного законодавчого підгрунтя для впровадження публічно-приватних форм організації лісогосподарського та деревообробного виробництва. Підписання Україною Угоди про асоціацію та про зону вільної торгівлі з $Є С$ вимагає усунення комплексу обмежень стосовно здійснення підприємницької діяльності та реалізації приватної ініціативи, а лісовий сектор не є винятком, що робить невідворотними інституціональні зміни у лісовому господарстві, деревообробному виробництві, целюлознопаперовій та лісохімічній промисловості.

Враховуючи те, що лісогосподарське виробництво перебуває у переважній більшості у державній власності, магістральною складовою механізму державного регулювання мають виступати методи та способи прямого впливу держави через збереження існуючої вертикалі управління лісовим господарством, бюджетного фінансування лісовідновлення, державного програмування розвитку лісового господарства та централізовано-індикативного планування лісогосподарських заходів. Також методами державного регулювання інституціональних змін у лісовому господарстві вистають базове лісовпорядкування, інвентаризація лісів, формування кадастру лісових запасів, які забезпечують об'єктивну оцінку стосовно величини лісоресурсного потенціалу і дають можливість прогнозувати обсяг деревини на короткострокову, середньострокову та довгострокову перспективу, яка надходитиме на ринок i виступатиме ресурсною базою розвитку вітчизняної деревопереробки або ж спрямовуватиметься на експорт.

Інша ситуація 3 підбором методів та інструментів державного регулювання інституціональних змін у переробному сегменті лісового сектора, оскільки він, за винятком деревообробних підрозділів державних та комунальних лісогосподарських підприємств, перебуває у приватній власності і держава може лише опосередковано впливати на відтворювальні пропорції в цій складовій лісового сектора. Формою державного впливу на приватний сегмент вітчизняної деревопереробки може бути надання державного замовлення, формування публічно-приватних партнерств на основі поєднання приватного і державного капіталу, а також надання різного роду фінансових преференцій у формі звільнення від ввізного мита на деревообробне обладнання, надання пільг при сплаті податку на прибуток та рентних платежів, а також компенсації частини відсотків за отримання кредитних ресурсів комерційних банків.

Проведені дослідження показали, що значним інституціональним розривом в системі державного регулювання розвитку переробних ланок лісового сектора $є$ надмірна звуженість джерел та методів фінансово-економічного забезпечення реалізації пріоритетів модернізації і реконструкції матеріально-технічної бази підприємств деревообробної, меблевої, целюлозно-паперової та лісохімічної промисловості. 3 огляду на це, важливого значення набуває інституціоналізація форм фінансового забезпечення розвитку переробних ланок лісового сектора через залучення коштів вітчизняних та іноземних приватних інвесторів (інвестиційних компаній, банків, трастових фондів та приватних підприємницьких структур). Приватні капітальні та фінансові інвестиції мають спрямовуватися на фінансування проектів створення сучасних деревопереробних виробництв, організації виробництв паливних ресурсів на основі переробки вторинної сировини та відновлення 
ЕКОНОМІЧНА НАУКА

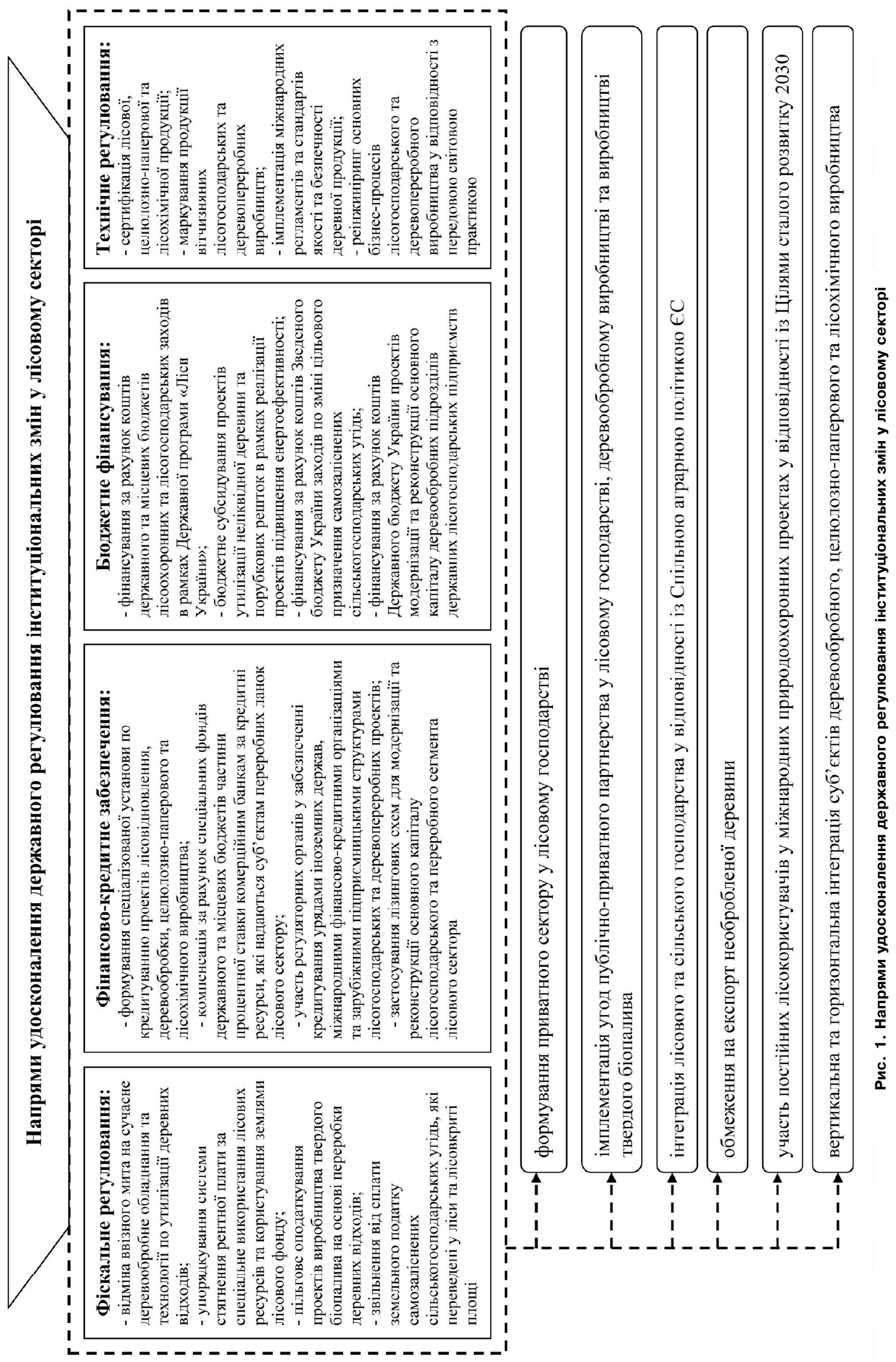


традиційних для України докризових потужностей у целюлозно-паперовій та лісохімічній промисловості.

Нині в Україні повною мірою ще не сформовано розвинене ринкове середовище функціонування лісогосподарських та деревообробних підприємств, тому першочергового значення набуває імплементація досвіду країн, де функціонували елементи командно-адміністративної системи, зокрема країн Центральної Європи. Передовий досвід високорозвинених країн може бути імплементований лише в тій частині, яка не суперечить базовим елементам функціонування вітчизняної моделі лісогосподарського та деревообробного виробництва.

На основі аналізу передового іноземного досвіду щодо державного регулювання інституціональних змін у лісовому секторі можна констатувати, що пріоритетними напрямами удосконалення вітчизняної інституціональної архітектоніки управління лісогосподарським та деревообробним виробництвом виступають: 1) кластерна форма організації лісогосподарського та деревообробного виробництва; 2) диверсифікація методів та інструментів фіскально-кредитного стимулювання ведення бізнесу у лісовому секторі; 3) використання інноваційних методів та технологій в управлінні лісогосподарським та деревообробним бізнесом. Невід'ємною складовою імплементації передового іноземного досвіду в частині інституціоналізації сучасних форм та методів організації лісогосподарського та деревообробного бізнесу є використання технологій бенчмаркінгу, факторингу та фандрайзингу.

Враховуючи високий рівень соціальної значущості лісогосподарського виробництва для господарства лісозабезпечених регіонів, інституціональні зміни у лісовому секторі мають відповідати інтересам місцевого населення, а тому потребують активного впливу зі сторони держави шляхом застосування комплексу регуляторних підойм. Виходячи із структурних особливостей лісового сектора національної економіки та враховуючи передовий іноземний досвід, удосконалення державного регулювання інституціональних змін у лісовому секторі має відбуватися за чотирма напрямками: фіскальне регулювання, фінансово-кредитне забезпечення, бюджетне фінансування та технічне регулювання (рис. 1).

Фінансові регулятори мають поєднуватися 3 технічними регуляторами, що дозволить крім кількісних сторін лісогосподарського те деревопереробного виробництва покращувати і якісні сторони, поступово наближаючи вітчизняну деревну продукцію до світових регламентів та стандартів якості і безпечності, що відповідає вимогам ряду директив $\mathrm{EC.}$

Виходячи з українських реалій, зокрема надмірної уніфікованості фіскальних регуляторів лісогосподарського та деревообробного виробництва, магістральним напрямом удосконалення державного регулювання інституціональних змін у лісовому секторі є розширення спектра фіскальних регуляторів, які стимулюватимуть процеси поглибленої переробки деревини та спонукатимуть лісогосподарські та деревообробні підприємства максимальною мірою утилізувати вторинну сировину та зменшувати їі питомі витрати. Останні зміни, які стосуються адміністрування лісоресурсної ренти i передбачають її нееквівалентне вилучення, можуть призвести до надмірного податкового тиску на постійних лісокористувачів, що змусить останніх на порядок підвищити ціни на деревину і призведе до цінових диспропорцій у різних фазах лісопродуктового ланцюга та зменшить рівень завантаженості потужностей у переробних ланках лісового сектора.

3 огляду на сказане важливою складовою удосконалення фіскального регулювання інституціональних змін у лісовому секторі має стати упорядкування системи стягнення рентної плати за спеціальне використання лісових ресурсів та користування землями лісового фонду в сторону обгрунтованого підняття лісових такс та перегляду міжбюджетного розподілу цього фіскаль- ного платежу [2], в тому числі і перерахунку їі частини у спеціальний фонд (Фонд розвитку лісового господарства), який необхідно створити у структурі державного та місцевих бюджетів. Також необхідно посилити диференціацію ставок рентної плати за використання лісових ресурсів загальнодержавного значення, а також місцевого, зокрема за заготівлю другорядних лісових матеріалів та побічні лісокористування.

У частині рентного регулювання використання земель лісового фонду особливого значення набуває надання преференцій суб'єктам аграрного підприємництва, а також домогосподарствам, які змінюють цільове призначення самозаліснених сільськогосподарських угідь, переводячи їх у ліси та лісовкриті площі. Тобто необхідно забезпечувати звільнення від сплати земельного податку тих суб'єктів господарювання та домогосподарств, які за рахунок самозаліснених сільськогосподарських угідь збільшують площу лісів та лісовокритих площ. Через звільнення від сплати земельного податку вдасться закласти необхідні стимули для збільшення площі лісів та лісовкритих площ на територіях, де мають місце масштабні природні ренатуралізації, особливо в зоні осушення, що корелює з передовою іноземною практикою, зокрема Спільною аграрною політикою ЕС у частині, яка стосується стимулювання фермерських господарств до збільшення площі лісових земель та захисних лісосмуг.

Поряд із удосконаленням фіскального регулювання інституціональних змін у лісовому господарстві має відбуватися модернізація фіскального інструментарію стимулювання процесів модернізації та реконструкції матеріально-технічної бази окремих деревопереробних сегментів лісового сектора. Виходячи з того, що вітчизняна деревообробка не відзначається навіть критично необхідним рівнем конкурентоспроможності у зв'язку із фізичним спрацюванням та моральним старінням основного капіталу, потребують інституціоналізації фіскальні регулятори, які стимулюватимуть імпорт деревообробного обладнання та технологій по утилізації деревних відходів. 3 цією метою важливою складовою удосконалення фіскального регулювання інституціональних змін у переробній ланці лісового сектора $€$ відміна ввізного мита на сучасне деревообробне обладнання та устаткування по утилізації деревних відходів. Відміна ввізного мита на цей вид обладнання зробить його більш доступним не лише для великих деревообробних компаній, а й для суб'єктів малого та середнього бізнесу, що дасть можливість у середньостроковій перспективі в цілому забезпечити технічне переоснащення індустрії деревообробки і тим самим розширити номенклатуру і асортимент продукції, що в кінцевому підсумку забезпечить покращення якісних характеристик готової продукції і сприятиме підвищенню рівня капіталізації деревообробного бізнесу в цілому.

Виходячи $з$ останніх трендів державної політики енергоефективності, значні перспективи відкриваються перед виробництвами, які забезпечують виготовлення твердого біопалива на основі переробки деревних відходів. Відповідні стимули для суб'єктів лісогосподарського та деревообробного виробництва будуть закладені через застосування інструментів пільгового оподаткування в разі реалізації проектів підвищення рівня утилізації неліквідної деревини, порубкових решток, кускових відходів, тирси та стружки, що в результаті дасть можливість на порядок збільшити обсяги виробництва паливних брикетів та гранул, що зменшить потребу ряду населених пунктів лісозабезпечних районів у викопних вуглеводнях та сприятиме зменшенню вартості енергоносіїв в цілому.

Вагомим каталізатором позитивних інституціональних змін у лісовому секторі $є$ доповнення фіскальних інструментів фінансово-кредитними регуляторами, оскільки "певні регуляторні зміни в податково-бюджетних відносинах економічних агентів у результаті рефор- 
мування потрібно спрямовувати на протидію чинникам фінансової нестабільності в територіально-часовому вимірі" [6]. Що дозволить зміцнити сектор малого та середнього підприємництва, особливо у деревообробному сегменті, а також інституціонально закріпити сучасні форми бізнесової діяльності у целюлозно-паперовому та лісохімічному виробництві. Суттєве покращення фінансово-кредитного забезпечення інституціональних змін у лісовому секторі залежить, у першу чергу, від формування спеціалізованої установи по кредитуванню проектів як у сфері лісового господарства, так і в переробних ланках лісового сектора. Аоцільність створення такої установи зумовлена відсутністю в останні роки достатніх обсягів бюджетного фінансування лісогосподарського виробництва, а також інвестиційним дефіцитом у сегменті деревообробних підприємств. Більше того, високий рівень капіталомісткості відновлення матеріально-технічної бази переважної більшості підприємств целюлозно-паперового та лісохімічного виробництва потребує значних обсягів інвестицій, фінансування яких може бути забезпеченим у разі наявності можливостей отримання кредитних ресурсів на вигідних умовах.

Такі вигідні для суб'єктів лісогосподарського, деревообробного, целюлозно-паперового та лісохімічного виробництва умови можуть бути досягнуті за умови наявності механізму компенсації за рахунок коштів спеціальних фондів державного та місцевих бюджетів частини процентної ставки комерційним банкам за кредитні ресурси, необхідні для модернізації та реконструкції як активної, так і пасивної частини основного капіталу деревопереробних виробництв. У короткостроковій та середньостроковій перспективі забезпечення суттєвого нарощення кредитування вітчизняними банківськими установами лісогосподарських та деревопереробних проектів $\epsilon$ надто проблематичним через низький рівень капіталізації банківських установ та відсутність у держави та територіальних громад можливостей компенсувати частину процентних виплат. За таких умов вагомого значення набуває залучення у лісовий сектор кредитних ресурсів урядів іноземних держав, міжнародних фінансово-кредитних організацій та зарубіжних підприємницьких структур. Формування відповідного інституціонального підгрунтя та каналів руху іноземних кредитів у лісовий сектор значною мірою залежить від діяльності регуляторних органів у частині покращення інвестиційної привабливості вітчизняного лісогосподарського та деревообробного бізнесу.

В умовах несформованості інституціонального підгрунтя для залучення як внутрішніх, так і зовнішніх кредитних ресурсів у лісогосподарський та деревопереробний сегмент лісового сектора додаткових імпульсів процесам прискорення модернізації і реконструкції основного капіталу лісогосподарського та деревопереробного виробництва має надати застосування такого фінансового інструменту як лізинг, який дозволяє придбати сучасне деревообробне обладнання через його оплату частинами.

Виходячи 3 того, що лісове господарство є складовою державного сектора економіки і у відповідності 3 вітчизняною законодавчою базою $є$ власністю українського народу, однією з основних складових державного регулювання інституціональних змін, особливо у лісогосподарському сегменті лісового сектора, є бюджетне фінансування. Така складова державного регулювання практикувалась в Україні як в радянський період, так і в пострадянський і певною міроюдовела високий рівень результативності. Однак поглиблення інституціональних змін в основних сегментах лісового сектора також потребують урізноманітнення методів та інструментів бюджетного фінансування лісогосподарських та деревообробних проектів.

Виходячи з практики фінансування лісогосподарського та деревообробного виробництва попередніх років, а також передових зарубіжних практик, фінансування за рахунок коштів державного та місцевих бюджетів лісоохоронних та лісогосподарських заходів має відбуватися в рамках виконання державних та регіональних програм, у першу чергу, Аержавної програми " $\Lambda$ iси України". Фінансування таких заходів на основі програмного методу дасть можливість ув'язати пріоритети розвитку лісового господарства та переробних підрозділів державних лісогосподарських підприємств 3 наявними фінансовими ресурсами та уникнути їх нецільового використання.

Підвищити дієвість інструментів бюджетного фінансування лісогосподарських та лісоохоронних заходів вдасться через створення у відповідних бюджетах спеціального фонау - Фонау розвитку лісового господарства, який буде формуватися за рахунок надходжень частини рентної плати за спеціальне використання лісових ресурсів та внесків державних лісогосподарських підприємств. Саме кошти названого фонду через інструменти бюджетного фінансування мають надаватися суб'єктам аграрного та лісогосподарського підприємництва при зміні ними цільового призначення самозаліснених сільськогосподарських угідь, тобто їх переведення у ліси та лісовкриті площі.

Також необхідно урізноманітнити інструменти бюджетного субсидування проектів утилізації неліквідної деревини та порубкових решток в рамках реалізації проектів підвищення енергоефективності, оскільки за нинішніх умов для державних лісогосподарських підприємств використання названих складових лісоресурсного потенціалу є невигідним і тому левова частка лісосічних відходів або ж спалюється, або ж спрямовується на звалища.

В окремих випадках має здійснюватися бюджетне фінансування також проектів модернізації і реконструкції основного капіталу деревообробних підрозділів державних лісогосподарських підприємств, особливо у випадках коли такі проекти дадуть можливість забезпечити якісно новий рівень переробки деревини і мультиплікативним чином вплинути на розвиток регіональних господарських комплексів лісозабезпечених районів.

В умовах необхідності апроксимації вітчизняної моделі організації лісового господарства до передових зарубіжних практик вагомого значення набуває становлення такої складової впливу держави на інституціональні зміни у лісовому секторі як технічне регулювання, яке передбачає обов'язкове здійснення сертифікації та маркування вітчизняної лісової, целюлозно-паперової та лісохімічної продукції. Водночас необхідною є також імплементація міжнародних регламентів та стандартів якості та безпечності деревної продукції, щоб мати можливість виходити на світовий ринок деревної продукції, що в підсумку сприятиме переорієнтації експорту лісосировини на експорт продукції з високою доданою вартістю. Поряд 3 впровадженням інструментів сертифікації та маркування вітчизняної деревної продукції та імплементації міжнародних регламентів та стандартів якості і безпечності цієї продукції має здійснюватися реінжиніринг основних бізнес-процесів лісогосподарського та деревопереробного виробництва, що дасть можливість поступово перейти на випуск продукції з деревини, якісні характеристики якої відповідатимуть загальносвітовим критеріям.

Виходячи із основних напрямів інституціональних перетворень у національному господарстві та враховуючи об'єктивні природно-ресурсні обмеження розвитку лісового сектора, основними складовими інституціональних змін у цьому секторі виступають:

- формування приватного сектору у лісовому господарстві (враховуючи необхідність розширення площі лісів та лісовкритих площ приватний сектор у лісовому господарстві України має формуватися на основі само- 
заліснених сільськогосподарських угідь, заліснення малопродуктивних земель);

- імплементація угод публічно-приватного партнерства у лісовому господарстві, деревообробному виробництві та виробництві твердого біопалива (враховуючи те, що основними лісокористувачами є державні лісогосподарські підприємства і вони не можуть бути роздержавлені чи приватизовані у зв'язку із необхідністю збереження лісів у державній власності, надати додаткових імпульсів реалізації приватної ініціативи у лісогосподарському виробництві та інших сегментах лісового сектора можуть угоди публічно-приватного партнерства, які передбачають збереження лісів у власності українського народу і дозволяють залучати ресурси приватного бізнесу);

- інтеграція лісового та сільського господарства у відповідності із Спільною аграрною політикою ЄС (такого роду інтеграція передбачає відновлення науково обгрунтованих захисних лісових смуг та здійснення інших видів агролісомеліоративних заходів, які унеможливлять процеси ерозії та дефляції грунтів та зменшать втрати врожаю);

- обмеження на експорт необробленої деревини (у зв'язку з дефіцитом лісосировини на вітчизняному ринку та у зв'язку з необхідністю відродження вітчизняної деревообробки було введено мораторій на експорт лісукругляка);

- участь постійних лісокористувачів у міжнародних природоохоронних проектах у відповідності із Цілями сталого розвитку 2030 (враховуючи високу екологічну цінність лісів та наближеність основних лісозабезпечених районів до кордонів ЄС однією з основних складових інституціональних змін у лісовому секторі має стати надання можливостей постійним лісокористувачам приймати участь у реалізації проектів $\mathrm{EC} \mathrm{по}$ відтворенню природної спадщини);

- вертикальна та горизонтальна інтеграція суб'єктів деревообробного, целюлозно-паперового та лісохімічного виробництва (з метою підвищення рівня концентрації інвестиційних ресурсів у деревопереробному сегменті через прямий та опосередкований вплив держави має відбуватися інтеграція суб'єктів деревообробного, целюлозно-паперового та лісохімічного бізнесу, що на порядок збільшить попит на лісосировинну).

\section{ВИСНОВКИ І ПЕРСПЕКТИВИ ПОДАЛЬШИХ РОЗВІДОК}

На основі проведених досліджень встановлено, що основними напрямами державного регулювання інституціональних змін у лісовому секторі виступають: фіскальне регулювання; фінансово-кредитне забезпечення, бюджетне фінансування та технічне регулювання. Перераховані напрями є взаємопов'язаними, що на різних ієрархічних рівнях вимагає їх поєднання на основі селективного вибору методів стимулювання суб'єктів лісогосподарського та деревообробного підприємництва до впровадження сучасних методів та технологій господарського освоєння лісоресурсного потенціалу та переробки деревних ресурсів. Поєднання перерахованих напрямів у короткостроковій перспективі забезпечить прямий та опосередкований вплив держави на формування приватного сектору у лісовому господарстві, імплементацію угод публічно-приватного партнерства у лісовому господарстві, деревообробному виробництві та виробництві твердого біопалива, інтеграцію лісового та сільського господарства у відповідності із Спільною аграрною політикою ЄС, обмеження на експорт необробленої деревини, вертикальну та горизонтальну інтеграцію суб'єктів деревообробного та лісохімічного виробництва.

Мітература:

1. Володимиренко В.М. Створення ефективного інструменту управління лісовим господарством. Науко- вий вісник Національного університету біоресурсів і природокористування України. Серія: Аісівництво та декоративне садівництво. - 2015. - Вип. 229. - С. 2026.

2. Гасанов С., Голян В. Фіскальне регулювання природокористування: перспективи модернізації. Економіст. - 2015. - № 12 . - С. 9-12.

3. Геєць В.М. Інституційна обумовленість інноваційних процесів у промисловому розвитку України. Економіка України. - 2014. - № 12. - С. 4-19.

4. Аейнека А.М. Аісовий сектор: аналіз структури, взаємодії з іншими секторами економіки та довкіллям. Регіональна економіка. - 2009. - № 3. - С. 144-151.

5. Єгорова Т.П. Ао питання впровадження в Україні інноваційної моделі розвитку лісової галузі. Право та інновації. - 2013. - № 4. - С. 42-53.

6. Єфименко Т.I. Фіскальний простір і стабілізація державних фінансів. Фінанси України. - 2017. - №9. - C. 7-28.

7. Касюхнич В.Ю. Інструментально-методичне забезпечення системи управління лісогосподарською діяльністю. Науковий вісник Херсонського державного університету. - № 15-1. - 2015. - С. 114-117.

8. Мицур I., Ткачів С. Світовий досвід використання механізму фіскального регулювання в лісовому господарстві. Економіка природокористування і охорони довкілля. - К.: АУ ІЕПСР НАН України, 2016. - С. $137-$ 144.

9. Мельниченко О.А. Аісове господарство як об'єкт державного управління. Теорія та практика державного управління. - 2015. - Вип. 3. - С. 24-30.

10. Печуляк В.П.Аержавне регулювання відносин у сфері лісового господарства: особливості визначення. Фінансове право. - 2012. — № 1 (19). — С. 38-42.

\section{References:}

1. Volodymyrenko, V.M. (2015), "Establishment of an effective forest management instrument", Naukovyy visnyk Natsional'noho universytetu bioresursiv i pryrodokorystuvannya Ukrayiny, seriya: Lisivnytstvo ta dekoratyvne sadivnytstvo, vol. 229 , pp. $20-26$.

2. Hasanov, S. and Holyan, V. (2015), "Fiscal regulation of nature management: prospects for modernization", Ekonomist, vol. 12, pp. 9-12.

3. Heyets', V.M. (2014), "Institutional conditions for innovation processes in industrial development of Ukraine", Ekonomika Ukrayiny, vol. 12, pp. 4-19.

4. Deyneka, A.M. (2009), "Forestry: analysis of the structure, interaction with other sectors of the economy and the environment", Rehional'na ekonomika, vol. 3, pp. $144-151$.

5. Yehorova, T.P. (2013), "On the issue of introducing an innovative model of forestry development in Ukraine", Pravo ta innovatsiyi, vol. 4, pp. 42-53.

6. Yefymenko, T.I. (2017), "Fiscal space and the stabilization of public finance", Finansy Ukrayiny, vol. 9, pp. $7-28$.

7. Kasyukhnych, V.Yu. (2015), "Instrumental and methodical support for the forest management system", Naukovyy visnyk Khersons'koho derzhavnoho universytetu, vol. 15-1, pp. 114-117.

8. Lytsur, I. and Tkachiv, S. (2016), "International practices of using the fiscal regulation mechanism in forestry", Ekonomika pryrodokorystuvannya i okhorony dovkillya [Environmental economics and environmental protection], Kyiv, DU IEPSR NAN Ukrayiny, pp. 137144.

9. Mel'nychenko, O.A. (2015), "Forestry as an object of state management", Teoriya ta praktyka derzhavnoho upravlinnya, vol. 3, pp. 24-30.

10. Pechulyak, V.P. (2012), "State regulation of relations in forestry: peculiarities of definition", Finansove parvo, vol. 1 (19), pp. 38-42.

Стаття надійшла до редакиї 31.10.2018 p. 
Тагиев Мурад Рамиз ог.,

д. э. н., профессор кафедры "международнал экономика",

Бакинский Государственный Университет

Ахундов Фарадж Таир ог.,

докторант, Институт Управленил при Начиональной Академии Наук Азербайджана

E. H. Тимощук,

д. т. н., директор, Институт водного транспорта

Государственного университета инфраструктуры и технологий

DOI: $10.32702 / 2306-6806.2018 .11 .15$

\title{
ВАИЯНИЕ ВНЕШНИХ ФАКТОРОВ НА АИНАМИКУ СТОИМОСТИ ЦЕННЫХ БУМАГ
}

\author{
Tagiyev Murad Ramiz, \\ Doctor of Economics, Professor, Department of International Economics, Baku State University \\ Akhundov Faraj Tair, \\ Ph.D., doctoral candidate of the Institute of Management at the National Academy of Sciences of Azerbaijan \\ E. Tymoshchuk, \\ Doctor of Technical Sciences., Director of the Institute of Water Transport of the State University \\ of Infrastructure and Technology
}

\section{INFLUENCE OF EXTERNAL FACTORS ON THE VALUE OF COST OF SECURITIES}

Сложные процессы, наблюдаемые в мировой экономике, рост предложений мировых рынков энергоресурсов, ослабление ряда крупных экономик и потребителей нефти, ослабление экономического роста в развивающихся странах, а также другие глобальные факторы оказали свое влияние на мировые цены на нефть. В период С июня 2014 года по настоящий момент цена на нефть снизилась более чем в 3 раза. Нертедобывающие компании, которые были тесно интегрированы в мировую экономику, были также затронуты этими процессами. Эта работа посвящена сравнению самых актуальных цен на нефть и облигаций нефтяных компании. Данная работа посвящена количественной оценки и сравнению цен на нефть и облигации нефтедобывающих компаний. На примере облигаций Государственной нефтяной компании Азербайджанской Республики (ГНКАР) и цен на нефть за 2014 год, мы посчитали корреляцию и определили СПособы ПодАержки цены на облигацию в условиях нефтяного кризиса в современной мировой экономике.

The complex processes observed in the global economy, the growth of supply of world energy markets, the weakening of a number of large economies and oil consumers, the weakening of economic growth in developing countries, as well as other global factors have had an impact on world oil prices.

The article defined the types of corporate securities. The influence of external factors on the pricing of bonds was also analyzed. External factors of influence on the price include economic, consumer; special foreign economic.

This work is devoted to the comparison of the most current prices for oil and oil company bonds. Statistical data on changes in oil prices and dynamics of the bonds of the State Oil Company of the Azerbaijan Republic (SOCAR) were collected. In the period from June 2014 to date, the price of oil has fallen more than 3 times. It also affected oil companies that were closely integrated into the global economy. The article analyzed that for the regulation of its finances and risk diversification, the State Oil Company of the Azerbaijan Republic (SOCAR) is actively involved in the international securities market. It was determined that to date, SOCAR has made 3 issue of fixed-rate coupon bonds - SOCAR 2017, SOCAR 2023, SOCAR 2030. 


\section{ЕКОНОМІЧНА НАУКА}

Of these 3 issues, SOCAR 2023 was chosen, as it has an average duration, unlike the other two. In this paper, the quantitative assessment of the dependence of the influence of world oil prices on the price of the DNCAR bonds is given. For this purpose, the statistics for 2014 were collected and a correlation analysis was carried out. In which the example of world oil prices and the value of bonds of the State Oil Company of Azerbaijan Republic have found that changes in commodity prices affect the financial performance and the price of securities of the same raw materials industry. Additional measures have been proposed that will keep falling prices for bonds under the oil crisis.

СкАадні процеси, які спостерігаються в Світовій економіці, зростання пропозицій Світових ринків енергоресурсів, ослаблення ряду великих економік і Споживачів нафти, ослаблення економічного зростання в країнах, що розвиваються, а також інші глобальні чинники здійснили вплив на Світові ціни на нафту.

Устатті було, дано визначення видів корпоративних цінних паперів. Також було проаналізовано вплив зовнішніх факторів на ціноутворення облігації. Ао зовнішніх факторів впливу на ціну можно віднести економічні, споживацькі; спеціальні; зовнішньоекономічні.

Цю роботу присвячено порівнянню найактуальніших цін на нафту і обігацій нафтових компанії. Було зібрано статистичні дані змін цін на нафту та динаміки вартості облігації,ержавної нафтової компаніі Азербайджанської Республіки (SOCAR). У період з червня 2014 до тепер ціна на нафту знизилася більш ніж у 3 рази. Також це вплинуло на Нафтовидобувні компанії, які були тісно інтегровані в Світову економіку. В статті було проаналізовано, що для регулювання Своїх фінансів ідиверсифікації ризиків Державна нафтова компанія Азербайджанської Республіки (АНКАР) бере активну участь на міжнародному ринку цінних паперів. Було визначено, що на сьогоднішній день,ДНКАР зробила 3 емісії купонних облігацій з ріксованою Ставкою - SOCAR 2017, SOCAR 2023, SOCAR 2030. 3 цих 3 емісій було обрано SOCAR 2023, бо має середню дюрацію на відміну ві, двох інших. УСтатті подано кількісну оцінку залежності вплив Світових цін на нафту на ціну облігаціїАНКАР. Аля цього були зібрані статистичні дані за 2014 рік і проведено кореляційний аналіз. У ході якого на прикАаді світової ціни на нафту і вартості облігації,Державної нафтової компанії Азербайджанської Республіки довели, що зміна ціни на сировинний товар впливає на фінансові показники і ціну цінних паперів гал узі цієї ж сировини. Ще були запропоновані додаткові заходи, які утримають падіння цін на облігацію в умовах нафтової кризи.

Ключевые слова: нефть, облигачии, Государственная нефтяная компания Азербайджанской Республики (ГНКАР ), Азербайджан, падение чен на нефть, внешние факторы, рынок корпоративных иенных бумаг.

Ключові слова: нафта, облігачї, Аержавна нафтова компанія Азербайджанської Республіки (АНКАР), Азербайджан, падіння чін на нафту, зовнішні фактори, ринок корпоративних чінних паперів.

Key words: oil, bonds, State Oil Company of Azerbaijan Republic (SOCAR), Azerbaijan, falling oil prices, external factors, corporate securities market.

\section{ПОСТАНОВКА ПРОБЛЕМЫ}

В условиях макроэкономической нестабильности, периодических банковских кризисов и обвалов на финансовых рынках развитых стран, значимость рынка ценных бумаг не вызывает сомнения. Рынок ценных бумаг делится на две категории: рынок государственных ценных бумаг, а также на рынок корпоративных ценных бумаг. Азербайджан, как динамично развивающаяся страна, осуществляет преобразования, оказывающие положительное влияющие на развитие локальных государственных и корпоративных рынков ценных бумаг. Рынок корпоративных ценных бумаг является неотъемлемым элементом жизнеспособности рыночной экономики. Особенностью развития данного сегмента финансового рынка в Азербайджане является стремительный, по сравнению с другими странами, темп его развития. Однако нельзя не учитывать, что в современном мире глобализации экономики, влияние внешних факторов на рынок ценных бумаг остается высоким. В статье на примере ГНКАР мы проанализируем влияние внешних экономических событий в ми- ровой экономике на элемент корпоративных ценных бумаг.

\section{АНАЛИЗ ПОСЛЕДНИХ ИССЛЕДОВАНИЙ И ПУБЛИКАЦИЙ}

Существует достаточное количество работ, посвященные исследованию данной темы. Среди знаменитых работ можно отметить работы Олейникова И.Н., Куз-

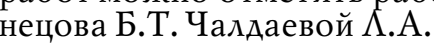

\section{ЦЕЛЬ СТАТЬИ}

Определение степени влияния внешних факторов на цену корпоративных ценных бумаг. Анализ теоретических методов диверсификации уровней влияния внешних факторов на динамику цен на рынке корпоративных ценных бумаг.

\section{РЕЗУЛЬТАТЫ ИССЛЕДОВАНИЙ}

1. Виды корпоративных ценных бумаг

Основную долю инструментов торговли корпоративными ценными бумагами занимают акции и облигации. 
Таблица 1.Общая информация ценной бумаги ГНКАР

\begin{tabular}{|l|l|}
\hline \multicolumn{2}{|c|}{ Общая информация } \\
\hline Валюта & USD \\
\hline Сумма выпуска Облигации & 1000000000 \\
\hline Вид купона & Фиксированный \\
\hline Периодичность выплаты & Полугодовой \\
\hline Current Coupon / Next Рay Date & $4.5 \%$ \\
\hline Дата закрытия купона & 13.03 .2023 \\
\hline
\end{tabular}

Акция - это ценная бумага, закрепляющая права ее владельца акционера на получение части прибыли акционерного общества в виде дивидендов, на участие в управлении акционерным обществом и на часть имущества, остающегося после его ликвидации.

Облигация- это эмиссионная ценная бумага, закрепляющая право ее владельца на получение от эмитента облигации в предусмотренный ею срок номинальной стоимости облигации и процента от нее либо иного имущественного эквивалента. Разница между инвестициями в акции и инвестициями в облигации в том, что облигации - это более консервативный финансовый инструмент, обладающий меньшей степенью риска. В течение последних нескольких лет в мире наблюдается тенденция к росту значимости рынков корпоративных облигаций и не исключено, что в связи с әтим рынки корпоративных облигаций будут активнее формироваться и развиваться. Облигации являются наилучшим способом привлечения крупных объемов долгосрочного заёмного финансирования. В связи с этим, эмитентами корпоративных облигаций являются крупные предприятия добывающей и обрабатывающей промышленности, компании по оказанию коммунальных услуг, а также финансовые институты - в первую очередь банки. Как раз такие предприятия, имеющие стабильный бизнес, нуждаются в таком роде финансирования. Облигация является инвестиционной ценной бумагой, следовательно, она предназначена для получения дохода. Исходя из предполагаемого дохода, облигации делятся на бескупонные и купонные. Также доход по облигации образуется от рыночной стоимости самой бумаги на рынке [1, с. 37].

Купонная облигация- облигация, по которым доход выплачивается с заранее оговоренной периодичностью (раз в месяц/квартал/полгода и т.А.) в размере заранее объявленной процентной ставки. Купонная ставка делится на два вида: на фиксированную (fix) и на плавающую(float). Различие между ними является то, что фиксированная ставка имеет неизменимую процентную ставку на весь период обращение облигации. Плавающая купонная ставка обычно привязывается к ставкам на межбанковских рынках (пример LIBOR), либо к ставке рефинансирования ЦБ страны эмитента. В качестве примера возьмём облигацию SOCAR 2023 и соберем в таблицу основную информацию (табл. 1) [2].

Бескупонная облигация - это облигация, доход по которой считается в виде дисконта. А именно, инвестор покупает ценную бумагу ценой ниже номинала, а в конце срока эмитент выкупает бумагу по номиналу. Разница между ценой покупки и номиналом и есть та сумма, которую получит инвестор в конце срока обращения облигации. Пример: облигация со сроком обращения в 1 год и номиналом в 100 манат выпускается по цене 90 манат и выкупается инвестором. По оконча-
Таблица 2. Средняя цена за нефть

\begin{tabular}{|l|l|l|l|}
\hline \multicolumn{1}{|c|}{ Месяц } & Средняя цена & \multicolumn{1}{|c|}{ Месяц } & Средняя цена \\
\hline Январь & $111,00 \$$ & Июль & $112,50 \$$ \\
\hline Февраль & $106,40 \$$ & Август & $105,60 \$$ \\
\hline Март & $109,44 \$$ & Сентябрь & $102,95 \$$ \\
\hline Апрель & $107,66 \$$ & Октябрь & $94,77 \$$ \\
\hline Май & $108,08 \$$ & Ноябрь & $85,85 \$$ \\
\hline Июнь & $109,70 \$$ & Декабрь & $70,15 \$$ \\
\hline
\end{tabular}

Нефть

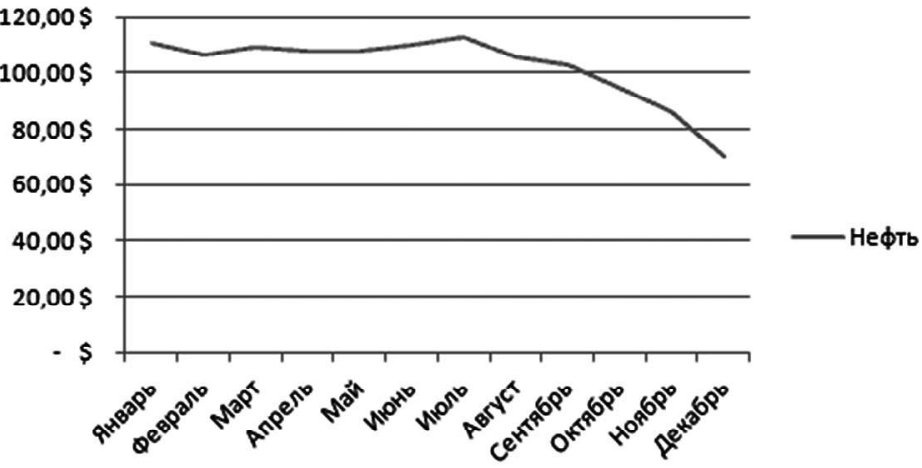

Рис. 1. Стоимость нефти за 2014 год

нию срока обращения, облигация выкупается эмитентом по номиналу (100 манат). Аоход составил 10 манат. Чтобы узнать сколько дохода в процентном соотношении получил инвестор, нужно посчитать текущую доходность. Текущая доходность характеризует годовые (текущие) поступления по облигации относительно понесенных при ее приобретении затрат. Текущая доходность облигации рассчитывается следующим образом:

\section{Текущая доходность $=$ \\ $=\frac{\text { Ежегодная выплата по облигации }}{\text { Рыночная цена приобретения облигации }} \times 100 \%(1)$.}

Следуя этой формуле получается: $11.11 \%$. Аоходность по данной бумаге составила $11.11 \%$. К классическим примерам бескупонных облигаций относятся долговые обязательства США (T-Notes) и Великобритании (T-Bonds).

По срокам обращения облигации разделяются на:

- краткосрочные;

- среднесрочные;

- долгосрочные;

- бессрочные;

Краткосрочные облигации-облигации со сроком обращения до 1 года, а среднесрочные от 2 до 5 лет. Аолгосрочные облигации имеют срок обращения больше 5 лет. Бессрочные облигации не имеют конечного срока обращения. Такие облигации выпускаются очень

Таблица 3. Средние цены SOCAR 2023

\begin{tabular}{|l|l|l|l|}
\hline \multicolumn{1}{|c|}{ Месяц } & Средняя цена & \multicolumn{1}{|c|}{ Месяц } & Средняя цена \\
\hline январь & $95,70 \$$ & июль & $100,24 \$$ \\
\hline февраль & $94,95 \$$ & август & $99,24 \$$ \\
\hline март & $95,11 \$$ & сентябрь & $99,18 \$$ \\
\hline апрель & $96,03 \$$ & октябрь & $99,25 \$$ \\
\hline май & $99,12 \$$ & ноябрь & $98,65 \$$ \\
\hline июнь & $100,15 \$$ & декабрь & $93,63 \$$ \\
\hline
\end{tabular}




\section{ЕКОНОМІЧНА НАУКА}

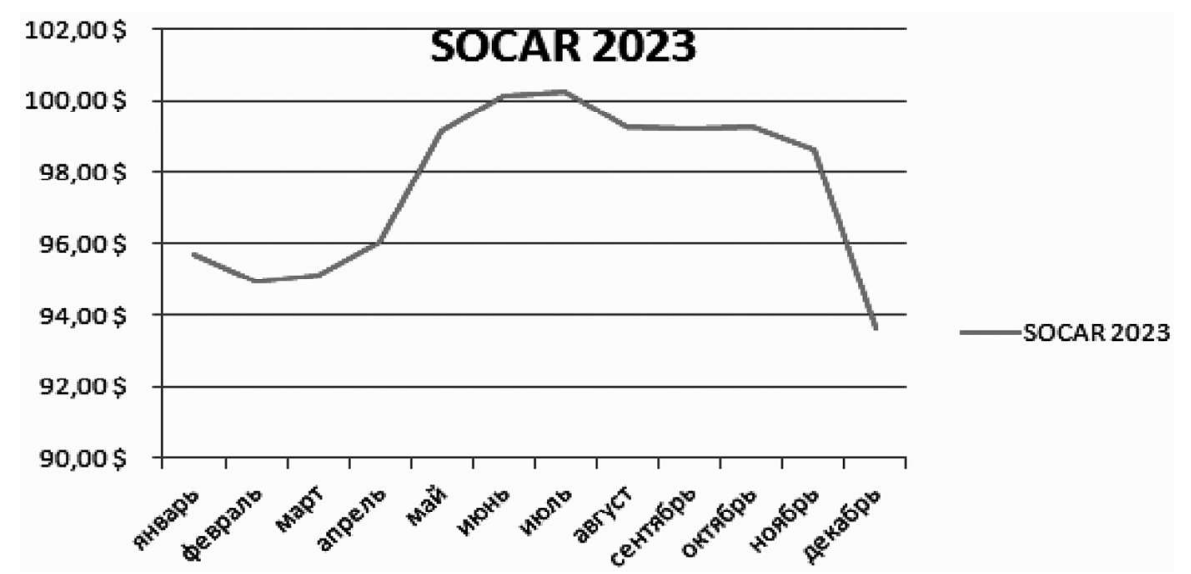

Рис. 2. Цена корпоративной облигации за 2014 год

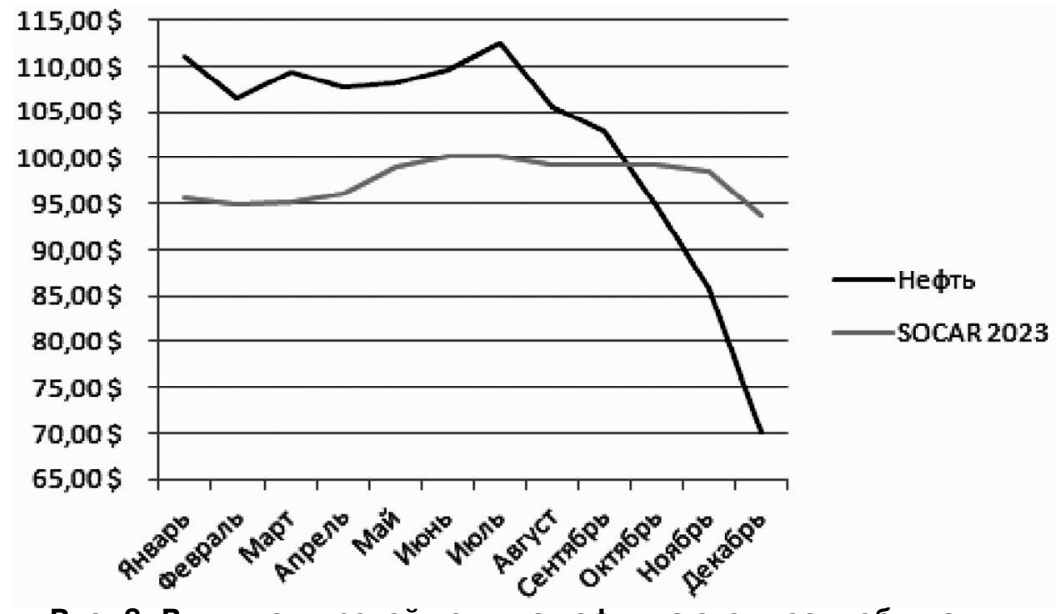

Рис. 3. Влияние мировой цены на нефть на стоимость облигации SOCAR 2023

редко, примером можно привести выпущенные во время Второй мировой войны военный заём (WarLoan) [3, c. 22$]$.

2. Влияние внешних факторов на ценообразование облигации.

В условиях современной рыночной экономики цена облигации, осуществляется под воздействием конкретной рыночной ситуации. Влияние внешних факторов на цену можно разделить на следующие группы:
- экономические;

- потребительские;

- специальные;

- внеэкономические.

К экономическим, относятся факторы, действующие независимо от вида продукции и условий её производства и реализации. Например, экономические циклы, спрос и предложение, инфляция. Потребительские факторы включают в себя сезонность, качество, надёжность, сервис. Специальными факторами, влияющими на ценообразование облигаций, являются государственное регулирование экономики страны, напри мер валютный курс; использование различных экономических инструментов (такие как монетарная политика, налоги, и т.А.). К внеэкономическим факторам, влияющим на цену облигаций, относятся геополитическая или военная ситуация в мире. Также влиянием на цену облигации следует учитывать различия в понятиях "цены продавца" и "цены покупателя" с учетом позиций отдельных сторон и рыночной ситуации. Цена продавца - цена, предлагаемая продавцом, а значит, относительно более высокая. Цена покупателя - цена, принимаемая и уплачиваемая покупателем, а значит, относительно более низкая [4, с. 122]. В зависимости от рыночной конъюнктуры ситуация с высокой или низкой ценой образуется в зависимости от преобладания на рынке спро-

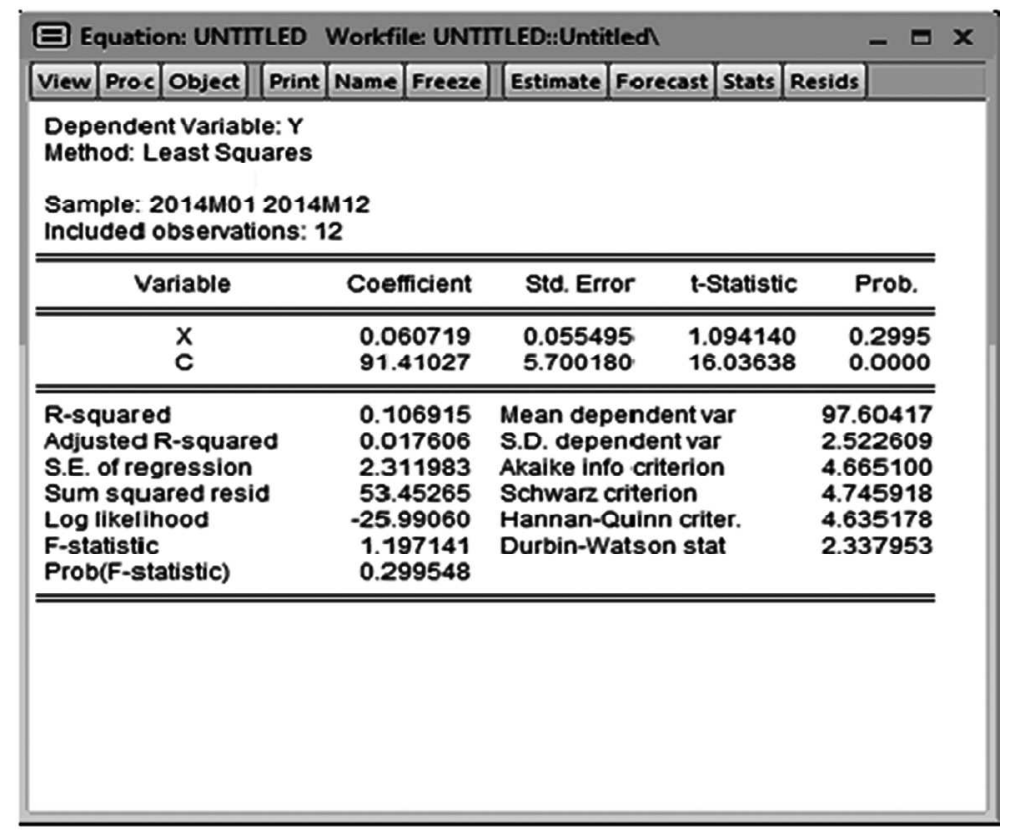

Рис. 4. Результаты вычисления на программе Eviews 7 
са или предложения. Рынок, на котором из-за преобладания спроса коммерческие показатели и цены диктует продавец облигации торгуются дороже, а рынок, на котором из-за преобладания предложения господствует покупатель ситуация в части цен противоположная. Однако эта рыночная ситуация все время меняется, что находит отражение в ценах. А это значит, что рынок находится в постоянном движении. Важную роль в ценообразовании на облигации, в особенности в мировой торговле, занимают сопутствующие услуги, цены на сырьевой рынок, особенно если компания сильно зависит от сырьевого ресурса. Этот аспект очень важен в современных условиях, в период развития высоких информационных технологий, усложнения машин и оборудования. Важно отметить, что в зависимости от эмитента динамика изменения цен сильно отличается. Так, при небольшом изменении конъюнктуры при влиянии внешних факторов наиболее резко и быстро меняются цены практически на все виды сырья, а реакция производителей и поставщиков машиностроения и легкой промышленности более замедленная [5, с. 355].

3. Влияние изменение мировой цены на нефть на цену облигации ГHКАР (SOCAR).

В данной статье мы дадим количественную оценку зависимости влияния мировых цен на, нефть на цену облигации ГНКАР. Аля этого мы соберем статистические данные за 2014 год изменения цен на нефть и динамики стоимости облигации Государственной нефтяной компании Азербайджанской Республики (SOCAR). Так как цены на нефть на мировом рынке образуются на основе спроса и предложения и меняются в течении каждой секунды, мы возьмём средние ежемесячные цены.

Несложно заметить, что общее движение цен находится в нисходящем тренде. Чтобы в этом убедится, построим график на основе вышеизложенных данных (рис. 1).

Государственная Нефтяная Компания Азербайджанской Республики является самой крупной нефтяной компанией на Южном Кавказе. Созданная 13 сентября 1992 года ГНКАР (на мировом рынке известен как SOCAR) смогла занять свою долю на рынке СНГ и во всём мире. За период своего существования расширила границы своей деятельности вплоть до Азии и Африки. Аля регулирования своих финансов и диверсификации рисков, ГНКАР участвует активно и на международном рынке ценных бумаг. На сегодняшний день ГНКАР сделала 3 эмиссии купонных облигаций с фиксированной ставкой - SOCAR 2017, SOCAR 2023, SOCAR 2030. Из этих 3 эмиссий выберем SOCAR 2023, так как имеет среднюю дюрацию в отличие от двух других. Рассмотрим средние цены на облигацию SOCAR 2023 за 2014 год (табл. 3).

Цена корпоративной облигации за 2014 год представлена на рисунке 2.

На цену облигации нефтяных компаний влияет мировая цена на нефть. Это означает, что вместе с падением цен на нефть, цена облигации будет терять свою стоимость. Аанная зависимость также касается облигаций SOCAR 2023.

Чтобы доказать данное влияние проведём расчеты на программе Eviews 7 (рис. 4).

Адекватность нашей эконометрической модели показывает полученный коэффициент Аарвин Ватсона приблизительно равен 2.33. Это значение определяет адекватность модели. Так как в условиях нефтяного кризиса, падение цен на нефть и соответственно падение облигаций будет влиять на доходы ГНКАР.

\section{ЗАКЛЮЧЕНИЕ}

В статье дана количественная оценка зависимости влияние мировых цен на нефть на цену облигации ГНКАР. Аля этого были собраны статистические данные за 2014 год и проведён корреляционный анализ. В ходе которого на примере мировой цены на нефть и стоимости облигации Государственной нефтяной компании Азербайджанской Республики доказали, что изменение цены на сырьевой товар влияет на финансовые показатели и цену ценных бумаг отрасли этого же сырья. Еще были предложены дополнительные мероприятия, которые удержат падение цен на облигацию в условиях нефтяного кризиса. Аля того чтобы поддержать цену облигаций ГНКАР должен сделать следующие шаги:

1. Снижение затрат.

В неблагоприятных финансовых условиях - это нормирование всех статей затрат и жесткий контроль исполнения установленных нормативов (бюджетирование). Этот подход позволяет снизить затраты компании до заданного уровня.

2. Стимулирование продаж облигаций.

Стимулирование продаж в ситуации кризиса должна выражаться в развитии отношений с существующими клиентами и привлечении новых, предложении рынку новой продукции, заключении контрактов на работу с давальческим сырьем, а также в пересмотре существующей системы скидок и льгот для покупателей.

3. Оптимизация денежных потоков.

Одним из выходов является ежедневная сверка баланса наличных денежных средств, которая даст менеджерам достоверную информацию о текущем остатке средств на счетах и в кассе предприятия, необходимую для принятия решений об осуществлении текущих платежей. Необходимо расставить приоритеты текущих платежей. Аалее составляется бюджет движения денежных средств на будущий отчетный период.

4. Реструктуризация кредиторской задолженности.

С покупателем заключается соглашение о том, что компания будет гасить задолженность по мере приобретения новых бумаг. Это один из методов. Второй подход - кредиторская задолженность погашается за счет краткосрочного банковского кредита, выданного на пополнение средств учетом реальной оборачиваемости "зависших" запасов, полученных от данного поставщика.

\итература:

1. Галанов, В.А. Рынок ценных бумаг: учебное пособие / В.А. Галанов. - М.: ИЦ РИОР, ИНФРА-М, 2011. $-223 \mathrm{c}$.

2. Обучение финансам и рискам: Thomson Reuters Eikon - версия 4 [Электронный ресурс]. - Режим доступа: https://emea1.apps.cp.thomsonreuters.com

3. Соколов Ю.А. Рынок ценных бумаг / Ю.А. Соколов// Учебное пособие. - М.: Издательство Юрайт, 2016. - 383 c.

4. Чалдаева $\Lambda$.А. Рынок ценных бумаг: учебник для бакалавров / М.А. Чалдаева, А.А. Килячков. - М.: Юрайт, 2012. -857 с.

5. Шешукова Т.Г. Рынок ценных бумаг: теория и практика: учебник / Т.Г. Шешукова. - М.: Финансы и статистика, 2008. - 752 с.

References:

1. Galanov, V.A. (2011), Rynok cennyh bumag [Stocks and bods market], IC RIOR, INFRA-M, Moscow, Russia.

2. Thomson Reuters Eikon (2018), "Financial \& Risk Training: Version 4", available at: https://emea1.apps.cp.thomsonreuters.com (Accessed 12 October 2018).

3. Sokolov, Ju. A. ( 2016), Rynok cennyh bumag [Stocks and bods market], Izdatel'stvo Jurajt, Moscow, Russia.

4. Chaldaeva, L.A. and Kiljachkov, A.A (2012), Rynok cennyh bumag [Stocks and bods market], Izdatel'stvo Jurajt, Moscow, Russia.

5. Sheshukova, T.G. (2008), Rynok cennyh bumag: teorija i praktika [Stocks and bods market: theory and practice], Finansy i statistika, Moscow, Russia.

Статта надійшла до редакиіï 31.10.2018 p. 


\section{ЕКОНОМІЧНА НАУКА}

УAK $336.71(477)$

S. Khalatur, doctor of Economics, associate professor, Associate Professor of Finance, Banking and Insurance Department, Dnipro State Agrarian and Economic University

N. Bilych,

student of gr. MGFBS-1-17, Dnipro State Agrarian and Economic University

DOI: $10.32702 / 2306-6806.2018 .11 .20$

\section{FINANCIAL TOOL OF LIQUIDITY MANAGEMENT OF COMMERCIAL BANKS IN THE NATIONAL ECONOMY OF UKRAINE}

C. М. Халатур,

А. е. н., Аоцент, доцент кафедри фінансів, банківської справи та страхування, Аніпровський державний аграрно-економічний університет

Н. С. Білич,

Студентка гр. МГФБС-1-17, Дніпровський державний аграрно-економічний університет

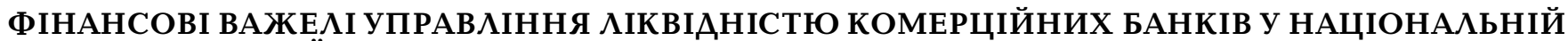
ЕКОНОМЦЦ УКРАЇНИ

Problems with liquidity in banks can lead to a reduction in the solvency of a commercial bank, which in turn results in the infiltration of other banks, resulting in a general loss of confidence in the banking system. Otherwise, solvent banks will suffer great losses as they struggle to mobilize less liquid assets to meet liquidity risk. These losses can quickly undermine the position of capital still weakly capitalized banks. The lack of the possibility of returning reserves and other illiquid banking requirements will force banks to write down these statements unreliable, which leads to significant losses and capitalization. Therefore, the study designed to determine the liquidity nisk is an endogenous factor that determines the solvency of the bank and ascertains the attitude and the level of materiality of banking specific variables and variables of macroeconomics with the level of risk of liquidity and solvency of commercial banks. After analyzing, it came to the conclusion that liquidity and solvency management is one of the most important tasks of managing a bank. Thus, in case of a general crisis due to internal or external political changes, seasonal effects, economic cycles, management will most likelyassess the impact of these trends and events on the financing of banks. Healthy financial management can counteract negative changes and emphasize positive. The risk of the interaction of liquidity and solvency, as a rule, leads to systemic crises.

Effective management of liquidity of commercial banks is crucial in the process of regulating financial payments, implementing international compliance and technological innovation practices that ensure the security of banking activities, capital security and strategic success of the financial industry as a whole. Large-scale modernization of national banking, growth of labor productivity, strengthening of competitive positions of domestic producers is possible on the basis of wide application of investment and innovation model of development. Among the measures to mitigate the negative effects, the main place should be state support.

Проблеми з Аіквідністю в банків можуть призвести до зниження платоспроможності комерційного банку, а це в Свою чергу до зараження інших банків, в результаті чого загальної втрати довіри до банківської Системи. В іншому випадку Платоспроможні банки зазнають великих втрат, так як вони борютьСя, щоб мобілізувати менш ліквідні активи,Ая задоволення ризикУліквідності. Ці втрати можуть швиАко підірвати позиції капіталу як і раніше слабо капіталізованих банків. Відсутність можАивості повернення резервів та інших неліквідних банківських вимог змусить банки записати ці твердження безнадійні, що призводить до значних втрат і капіталізації. Тому дослідження призначене для визначення ризику ліквідності є ендогенним фактором, що визначає платоспроможність банку та з'ясовує Ставлення і рівень Суттевості банківських конкретних змінних та змінних макроекономіки з рівнем ризику Аіквідності $і$ Платоспроможності комерційних банків. Після аналізу прийшлидо висновкУ, що УПравління Аіквідністю та платоспроможністю є однією з найбільш важАивих завдань управління банком. Таким чином, У разі загальної кризи через внутрішні або зовнішні політичні зміни, сезонні ефекти, економічні цикли, управАіння буде швидше за все оцінити вплив цих тенденцій і подій на фінансування банків. Здорове фінансове управління може протидіяти негативним змінам і підкреслити позитивні. Ризик взаємодї ліквідності та платоспроможності, як правило, призводить до системних криз.

Ефективне управління Аіквідністю комерційних банків є вирішальним у процесі регулювання фінансових платежів, реалізації міжнародної відповідності та технологічної інноваційної практики, що забезпечує безпеку банківської, діяльності, безпеку капіталу та стратегічний успіх розвитку фінансової галузі в цілому. Масштабна модернізація національного банківництва, зростання продуктивності праці, зміцнен- 
ня конкурентних позицій вітчизняних виробників можАиво на основі широкого застосування інвестиційно-інноваційної моделі розвитку. Серед заходів щодо пом'якшення негативних наслідків, основне місце повинно належати,державній підтримці.

Key words: commercial bank, financial condition, liquidity, solvency, borrowers.

Ключові слова: комериійний банк, фінансовий стан, ліквідність, платоспроможність, позичальники.

\section{INTRODUCTION}

In today's economic conditions it is undeniable that the basis of an expanded reproduction of productive forces and industrial relations is the accumulation of bank capital. It is bank capital, its sufficiency, maneuverability and liquidity - this is the main requirement and foundation of the activities of Ukrainian banks in a globalized environment. It is the capital that provides the basis for ensuring financial stability and maximally meeting the needs of economic entities of the national economy of Ukraine in financial resources.

In many respects, financial institutions, including commercial banks, are the center of financial crises. Generally, the reason for the crisis is usually due to three, possibly interwoven, problems in many banks: high leverage, backed by cheap loans, the use of complex derivative products, and low reserves against unforeseen losses. Commercial banks are inseparable in everyday life. It's unthinkable that anyone in a modern society can live without interacting with banks for a long period of time. Companies of different industries, structures and sizes are used for frequent and routine interactions with banks in many aspects of economic activity in general, the cycle of their existence, from creation to disappearance through mergers or acquisitions or bankruptcy.

Companies do not want to continue otherwise routine interaction with troubled banks. Therefore, it seems that banks are crucial for the well-being of our societies. In addition, agency problems related to banks are somewhat more complex, since not only direct investors in banking products, such as depositors or shareholders who have suffered, but the general public and the general economy may be in danger if banks are collectively faced with troubles The problems are compounded by the fact that banks are opaque enterprises, which means that it is very difficult for outsiders to accurately assess the true level of risk of a bank. As a result, the public seeks to extrapolate the problem of one bank with all other banks, assuming that the problem of a typical bank has proven, probably exists in other similar opaque institutions. Therefore, as during subprime crisis, depositors tend to simultaneously withdraw their bank deposits after observing the financial difficulties of one bank, although there is no direct sign of insolvency in other banks. For regulators and other stakeholders in banking lending and the use of their derivatives to reduce risks, it is relevant to study the real impact of bank capital on regulation and creation of bank liquidity. It is also necessary to consider the effect of competition on the creation of liquidity of the bank.

\section{ANALYSIS OF RECENT RESEARCH AND PUBLICATIONS}

The financial leverage of the management of liquidity of the commercial bank was considered in the writings of many scholars of researchers.

For example, Larysa Sloboda examines the main causes and important components of the banks' liquidity management approach based on the analytical results of cross-border transactions, analyzes various types of costs. Modern ways to improve the level of quality management of liquidity is the identification and assessment of operating costs in banks. Tools for improving the quality of liquidity management of commercial banks should include: definition of operating costs and compliance with cross-border financial transactions; development of cost management methods with the help of innovative technologies; improvement of cooperation with professional consulting companies; adaptation of banking operations in accordance with changes of any normative acts.

Suhartono Suhartono notes that the importance of the banking industry in the national economy has been recognized as the banking sector can contribute to the growth of the economy. Efficiency is an indicator of success in resources, and is also considered a prerequisite for survival in a competitive market. From this point of view, efficiency or optimal results are achieved through the use of scarce resources to achieve the desired level of production. Productive efficiency for the banking sector in the economy is defined as the ability of the bank to produce products at a lower price. In combination with industry organizations, the term efficiency is associated with the most productive way to use resources that are scarce. The better rewarding bank tends to be more efficient as a result of the economic capital effect. Efforts to scale up should be optimal. As a result, a commercial bank should maximize the benefits of scale for generation of production information. This is the only way to effectively manage the liquidity of a competitive banking business.

Nabil Bello, Aznan Hasan and Buerhan Saiti write that liquidity in finances is defined as an asset that is considered to be liquid if it has any of two main features: proximity to cash or easy cash-to-asset conversion. However, there is also a wide range of assets depending on its proximity to liquidity, which determines the liquidity of this item or asset. The technical plan defines liquidity as "the ability of a financial institution to easily meet cash and collateral obligations at a reasonable price". This liquidity definition is based on the objective of liquidity because the purpose of storing various assets is to fulfill the obligations of the bank. Moreover, the liquidity problem in relation to banks has two aspects. The bank needs access to liquidity on its part of the liability, known as liquidity of financing, and, secondly, access to liquidity through the monetization of assets known as market liquidity or assets. These two tasks are interconnected and banks need to take them into account at the same time. As a rule, liquidity risk is that there are terms for differences between cash flows from enterprises and cash outflow for business needs and repayment of debt obligations.

The liquidity risk relates to the risk that the financial position of the institution or overall security and reliability negatively affects the inability (or perceived as failure) to fulfill its obligations. Liquidity risk seriously affects the performance of banks in the national economy of Ukraine, their income and capitalization. Therefore, research of financial levers of liquidity management of commercial banks is a topical issue.

The purpose of the article is to find the best financial levers of liquidity management of commercial banks in the national economy of Ukraine.

\section{RESEARCH RESULTS}

For a number of reasons, Ukrainian banking is interesting for the empirical field of banking research. First, financial markets are seen as banking systems where banks are the largest providers of business liquidity. Is such a bankoriented financial market making banks more powerful in creating liquidity is an interesting empirical issue. Secondly, the Ukrainian banking sector has been transformed in the last decades by regulatory developments. These rules have consequences both at the level of competition of the banking sector in general and the competitive position of individual banks in particular. This has great political significance for 


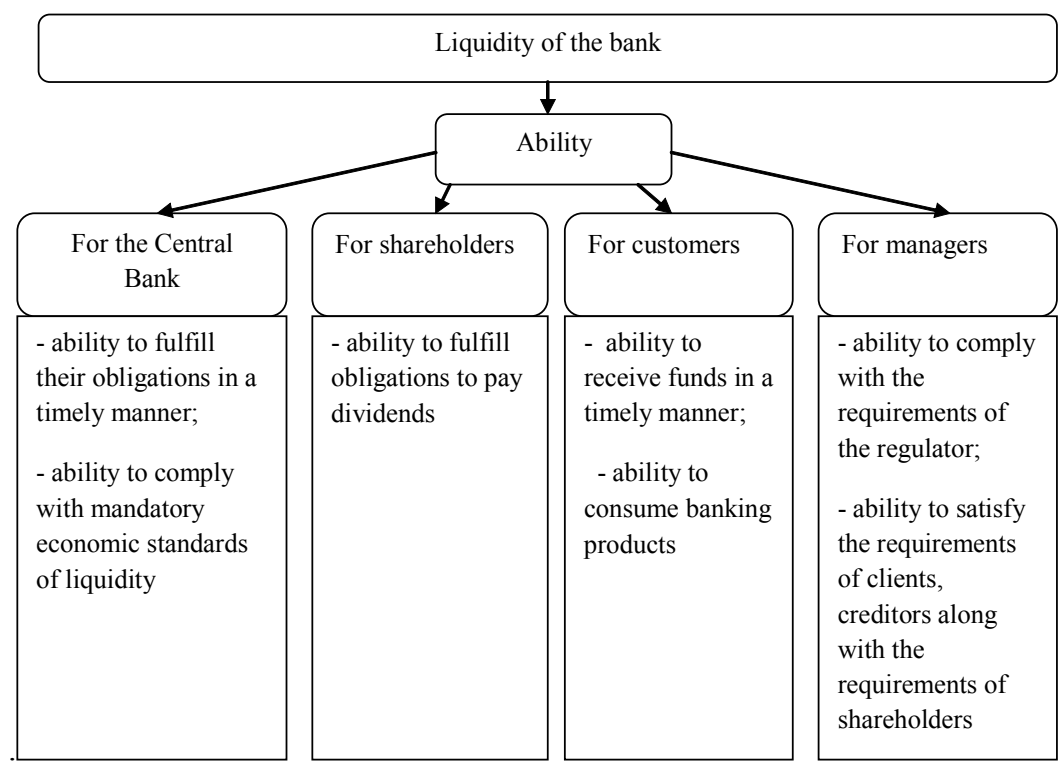

Fig. 1. The essence of the concept of "liquidity of the bank" [own development]

exploring ways to create banks' liquidity and related competition issues.

Next, we explore the relationship between equity and liquidity, thereby spilling light on the potential impact of recent changes in the regulatory focus of strengthening the bank's capital base. Our results show that an increase in the

\begin{tabular}{|l|l|l|}
\hline \multicolumn{3}{|c|}{ Subjects of management } \\
\hline $\begin{array}{l}\text { Supervisory Board } \\
\text { Top management }\end{array}$ & $\begin{array}{l}\text { Risk Management } \\
\text { Division } \\
\text { Internal Audit Service }\end{array}$ & \multicolumn{1}{|c|}{ Tactical level } \\
\hline \multicolumn{2}{|c|}{ Operational level } \\
\hline
\end{tabular}

Fig. 2. Bank liquidity management system and place of analysis in it [own development] bank's equity will significantly reduce the establishment of bank liquidity by all banks. This conclusion can be understood in the context of consistent government interventions and protection during the banking crisis by European governments. Such a regulatory environment leads to an ideology that banks will never be able to fail, which in turn reduces the need to hold their own capital.

In addition, the market share of individual banks is growing significantly, which is a positive relationship with the creation of liquidity. We consider this to be evidence of the stronger capabilities of banks with a larger market share to keep customers and interest rates so that risky and illiquid loans can be funded. More investment in these loans, in turn, will increase the bank's liquidity creation.

Separately, financial institutions regularly conduct stress tests for risk management purposes. In these internal exercises, commercial banks develop and implement their own stress testing programs that measure their ability to meet capital and liquidity requirements in stressful situations.

The design of scenarios for determining the horizons of liquidity and solvency risk is proposed. For monitoring purposes, the choice of the risk horizon is important in design terms, which will provide valuable information for policy discussion. While the degree of uncertainty also increases, as the risk horizon is lengthened, uncertainty also increases, as the risk horizon is lengthened, should adequately capture any medium-term effects of shocks. Unlike the sensitivity test which is usually used to estimate instantaneous shocks. As with other aspects of stress testing, expert judgment is crucial — while five-year horizons are usually used in their macro scenarios, exceptions may be made where the staff minds that using a longer-term sample may be unconstructive.

Given the financial crisis, the most relevant correlation is between equity and liquidity creation. The need for banks to have more equity capital cannot be credible and effective in such an environment, as banks expect the government to succumb to them during the crisis.

Forcing banks to hold more capital can reduce their liquidity and slow down its economic growth and recovery. However, during a crisis of subprime risk, almost all major European governments again provided support of various kinds to prevent the bankruptcy of their banks, which could further strengthen banks in the future, depend on the government and reduce their incentive to hold capital. Forcing banks to hold back more capital can become even more counterproductive when recovering from the financial crisis.

The success of bank liquidity creation is determined not only by the investments of banks, but also their source of financing. Banks only create liquidity when they are able to finance illiquid assets under liquidity obligations. Consider the role of equity in creating liquidity of banks in the light of two opposite directions. On the one hand, an unstable bank capital structure, mainly made up of liquidity deposits, is necessary to create a bank's liquidity, forcing the bank to monitor and collect loans and transfer income to depositors. Equity that reduces fragility will reduce the commitment of banks to depositors and, consequently, their ability to generate liquidity. The illiquid equity may squeeze out liquid deposits and thus make the liability side of the banking 


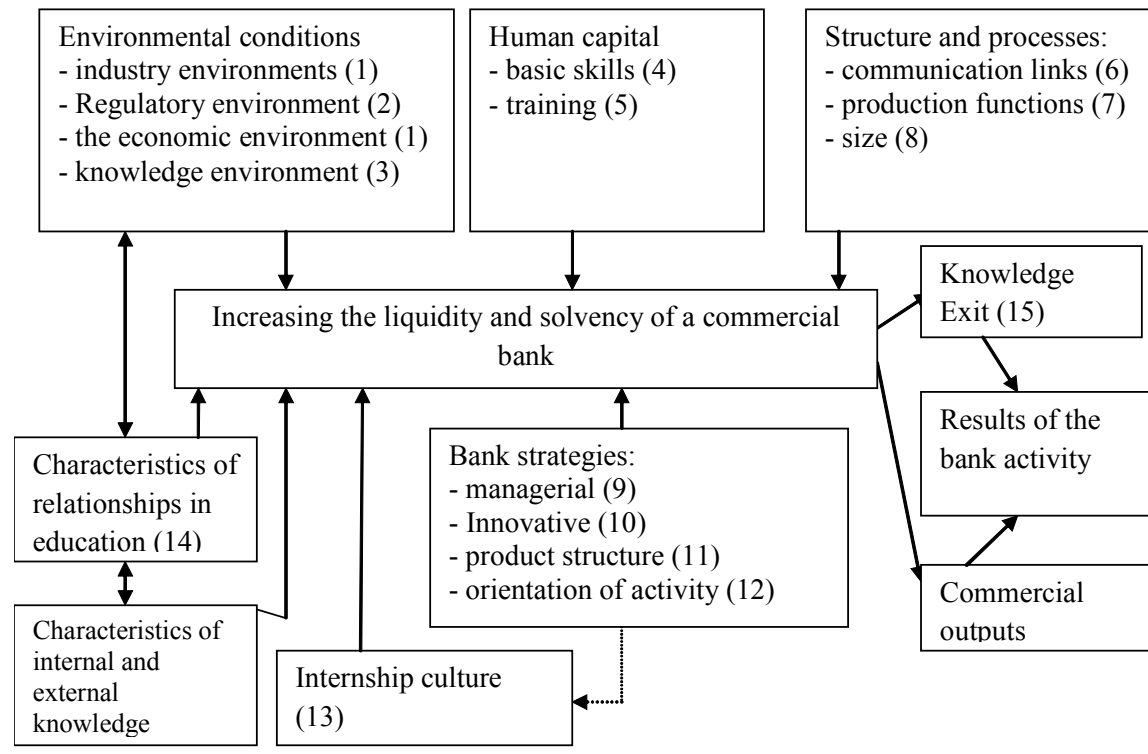

Fig. 3. Block diagram of research of liquidity and solvency increase elements of commercial bank

Source: own research.

sector less liquid. In other words, the smaller part of the bank's liability impedes the creation of liquidity of the bank. On the other hand, equity can be useful for creating bank liquidity because of its ability to absorb risks.

Banks need to have a certain equity capital to cope with unforeseen losses caused by risk features, such as credit risks. Since banks create liquidity in the financing of risky and illiquid loans, that is, loans with a high level of individual risks, keeping a higher level of equity capital becomes essential for banks to create liquidity. More capital could strengthen liquidity creation.

Government protection, implicit or explicit, can be a substitute for justice for risk taking. In other words, it is better for banks to hold less equity capital, subject to a stronger state guarantee. As a consequence, the role of equity in risk perception and facilitating liquidity creation can be reduced. In general, the theoretical prediction of the role of equity in creating the liquidity of Ukrainian banks offers a negative relationship.

The equity role is also highly negative for the creation of liquidity by small banks that are less likely to reduce risks through diversification or hedging and, therefore, should receive return on equity in the process of risk absorption. Taking into account such an institutional context, the imposition of capital regulation, at least the need for capital (revised) at Basel II, may have a negative effect on the banks' liquidity creation in Ukraine.

Consider how the market share of individual banks and the competitive landscape of the banking sector affect the creation of liquidity. On the one hand, a high level of market concentration makes it more likely that it is small and risky borrowers can get bank loans, because banks in a more concentrated market can simpler intermittently smooth interest payments on loans. On the other hand, the performance structure in banking practice suggests that market power is likely to negatively affect the creation of bank liquidity, since banks in a less competitive environment are less likely to adapt their range of services and pricing structures to suit their customers' needs, and thus, demand for banking services will decrease.

Next, we'll look at whether our results are managed by the bank's property. Banks with foreign operations may have more opportunities to diversify their portfolios to a broader base of customers, which in turn can reduce risks and improve liquidity creation. However, foreign banks may not have sufficient knowledge of the local market and consumers, of competitors that may force them to rely on standardized and liquid loans instead of lending relationships and, in turn, reducing liquidity.
The SWOT analysis examines the characteristics of a commercial bank activity both within the investigated bank and in a commercial environment. Internally, the analysis reveals strengths, such as the fact that the commercial bank does well, the quality of its employees, the degree of product differentiation and customer loyalty. He then focuses on weaknesses such as responsibility for product quality, poor funding, and lack of innovation. An external analysis determines the opportunities for growth and trends that can benefit a commercial bank and seeks solutions to problems such as increased competition, potential costs and potential of legislation or regulations that could damage the bank.

The commercial bank must develop a strategic approach to address possible threats and address its shortcomings. In order to increase the liquidity and solvency of a commercial bank, taking advantage of the opportunities available, building on the strengths of the company requires a comprehensive approach. An integrated approach builds on the strengths to eliminate weaknesses and exploits the benefits to take advantage of and eliminate threats. For example, the bank has a strong technical team, but its products are of poor quality. It threatens low price competition in one industry, but it is possible to get a lot of investment support in the new market. An integrated strategy utilizes innovations and technical group experience to solve liquidity and solvency problems of the bank. It uses advanced technology to produce highquality products to gain new customers and expand on this market.

When developing a strategic approach to increasing the liquidity and solvency of a commercial bank using SWOT analysis, it shows how it is possible to invest and what improvements can result from investments. You can use the streng ths to eliminate disadvantages, reduce the threat, and use the opportunities in several ways. The development of such comprehensive strategies for increasing the liquidity and solvency of a commercial bank allows us to assess what investments are needed to implement each initiative. A results-oriented approach to a number of investment opportunities improves the position of a commercial bank.

It is necessary to assess the benefits to decide what investment value is necessary. While it is possible to calculate the return on investment, the SWOT analysis can reveal other improvements in the bank. For example, it is possible to compete with other manufacturers at a low price. If this strategy works, it's possible to get market share, but with low profitability. Investing in innovative production, which allows producing high-quality products, will contribute to the emergence of new customers, a strong technical team.

In considering opportunities for increasing liquidity and solvency of the bank, it is interesting to study the basic skills and training of staff (Figure 3, item 4).

In order to establish the level of basic skills in the bank, respondents should indicate the highest level of qualification of management personnel, as the research is interested in the effect of the educational-qualification level of the bank's management on the liquidity and solvency. Training (Fig. 3, item 5) In order to set the level of investment in training the personnel of a commercial bank, respondents should ask the question: "How much, on average, spent the last three years directly on the training of bank staff?"

For the size of a commercial bank (Figure 3, item 8), it is possible to classify using the size of assets and the number of employees. In order to examine the level of participation of managers in developing an investment strategy (Figure 3 , item 9), it is necessary to indicate the level for which they 
Table 1. SWOT matrix for commercial bank

\begin{tabular}{|c|c|}
\hline $\begin{array}{l}\text { Strengths: } \\
\text { 1. reliability of the bank } \\
\text { 2. Flexible approach to each client; } \\
\text { 3. branched branch network; } \\
\text { 4. high liquidity indicators; } \\
\text { 5. Leading positions in the banking services market for more than } \\
\text { 20 years; } \\
\text { 6. Sufficient financial resources }\end{array}$ & $\begin{array}{l}\text { Opportunities: } \\
\text { 1. attraction of new borrowers; } \\
\text { 2. loan portfolio expansion; } \\
\text { 3. expansion of the branch network; } \\
\text { 4. realization of investment projects; } \\
\text { 5. introduction of new banking products. } \\
\text { 6. entering into new segments of the market }\end{array}$ \\
\hline
\end{tabular}

Source: compiled by the authors on the basis of [5-7].

agreed with the following statement: "Top and middle managers are always directly involved in the development of new investment alternatives" (possible range of answers: from 1 to 5 , where 1 - disagree, 5 - totally agree).

In order to establish the existence of innovative strategies (Figure 3, paragraph 10) of a commercial bank, respondents should be asked to give details of the formal innovation strategy and its place of increase in the value of investment support. Respondents who answered positively about the availability of the official strategy will receive 2 points, while negative answers will receive 1 point and no answer 0 points. It is important to take into account when analyzing the answers to the question about the availability of formal commercial bank strategies in an open format, in contrast to the closed format of the rest of the issues discussed.

The structure of services (Fig. 3, item 11) plays an important role in an attempt to identify banks that value the range. The orientation of a commercial bank (Figure 3, item 12) is assessed by identifying the types of activities that the bank conducts. There are three variants of orientation for banks: products (services), process and market. In-house culture (Figure 3, Paragraph 13), in order to develop measures to assess the impact of the culture of a commercial bank, respondents should be asked to answer the question "I work in a bank because ...", it is possible to obtain two types of estimates: a positive culture and negative culture.

Based on the study of increasing the liquidity and solvency of the commercial bank, a refined matrix with the inclusion of the necessary information was proposed and the following hypotheses that require empirical verification have been developed.

1) increasing awareness of the influence of the business environment and participation in innovation activity is influenced by the liquidity and solvency of the commercial bank;

2) increasing awareness of competitiveness and terms of business affects the liquidity and solvency of a commercial bank;

3 ) increasing the level of awareness of management personnel on economic conditions affects the liquidity and solvency of a commercial bank;

3 ) increasing awareness of the regulatory environment affects the liquidity and solvency of the commercial bank;

4) awareness raising about the environment affects the liquidity and solvency of the commercial bank;

5 ) the probability that a commercial bank is engaged in different types of innovations, increases with certain favorable internal factors, certain potential, scale of the bank, ability to absorb external information will positively influence the liquidity and solvency of the commercial bank;

6) raising the level of certain favorable internal factors affects the liquidity and solvency of a commercial bank

7) the degree to which the bank assumes the influence of the business environment on innovation activity affects the liquidity and solvency of the commercial bank;
8) The level of priority of commercial challenges and outcomes of knowledge and participation in technological innovations affects the liquidity and solvency of a commercial bank.

Let's consider in more detail the threat of liquidity and solvency of a commercial bank. This part of the external analysis during a strategic analysis gives a certain idea of the various factors of the macroeconomic environment that every commercial bank has to take into account.

Political factors or how and to what extent the state interferes with the economy. In particular, political factors include areas such as tax policy, labor law, environmental law, trade restrictions, tariffs and political stability. Political factors may also include goods and services the production of which the government wants to provide or support and vice versa. Economic factors include economic growth, interest rates, exchange rates and inflation rates. These factors have a significant impact on the way in which agricultural enterprises and decision-making work. For example, interest rates affect the value of bank capital and, consequently, to a certain extent, investment support is growing and expanding. Foreign exchange rates affect the value of exports of goods and offers and prices of imported goods in the economy. Social factors include cultural aspects, consciousness, health, population growth, age distribution, career relationships, and emphasis on safety. Trends in the influence of social factors affect the demand for agricultural products and opportunities for its development. For example, aging of the population can mean less workforce (which leads to an increase in labor costs). In addition, commercial banks can change management strategies to adapt to these social trends (for example, the recruitment of older workers).

Technological factors include environmental and environmental aspects, such as automation, technology, incentives and pace of technological change. They can identify barriers to entry, the minimum effective level of production, and influence decision-making on outsourcing. In addition, technological changes can affect costs, quality and lead to innovation, which requires investment support for production. Environmental factors include weather conditions, climate, climate change, which can affect areas such as tourism, agriculture and insurance. In addition, growing attention to climate change affects the work of a single bank and the products they offer - both the creation of new markets and the reduction or elimination of existing ones. Legal factors include legislative acts, consumer protection law, antitrust law, and labor law and labor protection. These factors can affect how the bank works, its costs, and the demand for its products.

The liquidity risk financing strategy is a key aspect of liquidity management, especially in terms of deposits and loans in the market. Debts and sources of diversified financing typically indicate that the bank has well-developed liquidity management. A portfolio of bank holding deposits in a stable and high diverse value may face liquidity problems less than banks without such portfolios. 
One of the main principles of liquidity risk management is diversification of deposits in the number of private clients and corporate, geographical distribution, types of accounts and instruments, repayment. Diversity provides stability and prevents money from reaching a certain day or for a certain period. Evaluating the structure, type and condition (stability and quality) of deposits is a starting point for assessing risk and liquidity. Thus information about:

- the range of existing portfolios, with the number of accounts, the balance of all depositors, and after certain classifications such as currency, maturity and interest rates;

- the concentration of deposits, deposits of individualsclients that exceed a certain total value of assets should be classified at the end of the term and interest rate;

- administration of deposits, information on the adequacy of accounting and control of operations and depositors access to internal clients and the accrual of interest and the form of payment.

Due to competition for funds, the management of the bank is not interested in adopting a development program to attract all types of deposits, both in terms of increasing the volume and quality of the deposit structure to determine the proportion of deposits that are stable or basic, volatile and volatile, and, to have adequate information about alleged and potential withdrawals.

Another key ingredient of liquidity is the ability to attract other debt instruments (also known as liquidity potential). This is important in assessing liquidity sources, taking into account additional costs of borrowed funds (marginal cost of liquidity) and other factors such as: the frequency with which a bank will be through refinancing obligations and its ability to raise funds from other sources. For a bank that often operates on the money markets in the short term, the key determinants of the ability to borrow a new fund are its location on the relevant market.

To manage liquidity risk, a bank requires certain limits of exposure to liquidity risk, with the help of an internal order correlates with explicit liquidity calculations, these limits are established in accordance with the annual liquidity management strategy developed by the management committee.

Sources of liquidity for the bank - primary, reserve:

- cash deposits, deposits with partner banks, corresponding to the minimum or maximum aggregate bank assets;

- secondary reserves held in the portfolio of securities in the total amount of bank assets;

- diversification of the portfolio, the maximum amount for the type of investment is the total assets, there must be several types of investment;

- the resource deficit - in the currency, the limit will be maximum, shares - in the national currency with a maximum limit (equity - fixed values);

- resources borrowed from partner banks - from total liabilities;

- conditions of correlation / repayment of assets and liabilities: repayment banks must be adjusted constant because of its commitment gap (equivalent) in the maturity, will have its limits of variation contained in certain values of the total assets, determined on the basis of their the goals of each bank and the propensity to risk their shareholder;

- the maximum admission to the establishment of the minimum mandatory reserve for the national currency and in foreign currency;

- Solvency assessment is required;

- restrictions on loans / deposits;

- restrictions on credit/ capital;

- indications of funding sources and directions;

- liquidity parameters, for example, the fact that liquid assets will not be lower than interest rates or rise above the percentages of total assets;

- Speed limitations on the relationship between planned financial needs and available resources to meet these needs, for example, that primary sources with more expected parameters will not be lowered as a percentage;
- the marginal interest rate based on a certain category of debts, for example, the fact that negotiable deposit certificates will not be the maximum of the total amount of debt;

- the average maturity term of minimum/ maximum of different categories of debt, for example, the average term of negotiable deposit certificates will not be less than a month.

These risk limits are confidential and are used only for internal use of the bank. Financing planning and liquidity after alternative scenarios. Although liquidity is usually carried out under normal conditions, the bank must be prepared to implement its management in special circumstances (abnormal). Liquidity management in special conditions (abnormal) includes asset management and liabilities under special conditions.

Thus, under normal conditions, liquid assets can be quickly converted into liquidity and at an acceptable cost, many banks also include assets in an analysis aimed at identifying sources of funds. However, the emergence of crisis markets has shown that asset sales will no longer serve as a source of effective liquidity facilities and the bank will have to decide how the liquidity of an asset will be considered in different scenarios. Some assets in the current environment can significantly reduce liquidity in unfavorable market conditions. This asymmetry of liquidity is an important element of growth due to the developed toolkit on the market. Thus, the bank's assets will fall in different groups of liquidity, depending on the forecasted scenario.

As for the obligations of banks, firstly, the bank should consider the evolution of its obligations for normal business, including the creation of such elements:

- the normal level of the deposit, that is, extend the maturity and other obligations with similar characteristics;

- Deposits with maturity, which do not constitute contractual terms, as current account and other savings accounts;

- normal grow th of new assets.

The analysis of cash flows is determined by the banks' obligations under abnormal conditions (specific to the bank or in connection with the general problems faced by the market) requires consideration of the following issues:

- which sources of funding have registered a high probability of staying in the bank, regardless of the existing conditions and how these sources can be increased;

- what sources of financing can gradually leave the bank, if there are certain problems and to what extent;

- whether interest rate subsidies can control the amount of resources;

- Does the bank have to hold objects as a backup, which can be carried out and under what conditions;

Obligations that make up the first category can be considered to remain in the banking system even in a pessimistic scenario. Some basic payments, as a rule, remain in the bank, as the deposits of individuals and small businesses are guaranteed or due to the bank transfer cost, which are prohibited for a very short period of time, these deposits can not be transferred.

The second category includes obligations with a high probability to remain inside the bank in the event of certain problems of medium intensity. These resources will flow gradually in the event of a crisis, may include some deposits that can be equated to the base one and were not included in the first category. In addition to these basic deposits, a certain level of interbank deposits may remain within the bank during such periods.

The third category of resources is resources without contractual repayment terms. One of the important elements of liquidity planning and risk management is the forecasting of possible future events. Banks should regularly assess the expected cash flows, rather than focusing on contracts during periods in which cash or cash outflows may occur. Liquidity risk management will take into account 
different options to determine if a bank or sufficient liquid assets depending on cash flows under different conditions. Thus, understanding in the context of liquidity risk management involves studying the approach to the source of financing and after alternative liquidity planning scenarios.

Analysis of bank liquidity using different types of scenarios "if". Each scenario, the bank should assess liquidity fluctuations - estimates (positive and negative). These scenarios will take into account internal factors (for a particular bank) and external (depending on the market). Continuous activity scenario is usually applied to managing a bank deposit point by setting a benchmark for cash flows associated with a balance sheet in the normal course of business.

The second scenario relates to banks' liquidity in a crisis situation that is typical of a bank when a significant part of its debt can not be replaced or refinanced, requiring liquidity monitoring measures.

The third scenario relates to general market crises, which affects the liquidity of a large part or even of the entire banking system. Liquidity management in this scenario reflects on the quality of loans; there are significant differences in access to finance between banks. From the point of view of liquidity management, an implicit assumption can be made that the Central Bank will allow access to funding in a certain form, because the Central Bank is particularly interested in studying this scenario, due to the need to create a general liquidity buffer for the banking sector, the operational allocation of the load between the most important issues liquidity of banks.

Conclusions and perspectives of further research. Effective management of liquidity of commercial banks is crucial in the process of regulating financial payments, implementing international compliance and technological innovation practices that ensure the security of banking activities, capital security and strategic success of the financial industry as a whole. Thus, increasing the liquidity and solvency of a commercial bank should be systemic, promote dynamic socio-economic development and increase the competitiveness of products, which requires careful SWOT analysis. Large-scale modernization of national banking, growth of labor productivity, strengthening of competitive positions of domestic producers is possible on the basis of wide application of investment and innovation model of development. Among the measures to mitigate the negative effects, the main place should be state support.

\ітература:

1. Управління ліквідністю банківської системи України: монографія / О.В. Азюблюк, В.Я. Рудан. - Тернопіль: Вектор, 2016. - 290 с.

2. Arif A., \& Anees A.N. (2012). Liquidity risk and performance of banking system. Journal of Financial Regulation and Compliance, 20 (2), 182-195.

3. Basel Committee on Banking Supervision (2013), Basel III: The Liquidity Coverage Ratio and liquidity risk monitoring tools. Basel Committee on Banking Supervision.

4. Dong Y, Hamilton, R., and Tippett, M. (2014), Cost efficiency of the Chinese banking sector: A comparison of stochastic frontier analysis and data envelopment analysis. Economic Modelling, 36, 298-308. Retrieved from https:// www.researchgate.net/profile/Yizhe_Dong/publication/ 259122913_Cost_efficiency_of_the_Chinese_banking sector_A_comparison_of_stochastic_frontier_analysis and_data_envelopment_analysis/linkss/559f179508ae0 $\overline{3}$ c44a5ce394.pdf

5. Fiordelisia, Franco, David Marques-Ibanez, and Phil Molyneux (2011), Efficiency and risk in European banking. Journal of Banking \& Finance, 35(5), 1315-1326. Retrieved from http://edz.bib.uni-mannheim.de/daten/edzki/ezb/ 10/w-paper/ecbwp1211.pdf

6. Grasshoff G., Mogul Z., Pfuhler T., Gittfried N., Wiegang C., Bohn A., \& Vonhoff V. (2017). Global Risk
2017: Staying the course in banking. Retrieved from: http:/ /image-src.bcg.com/ BCG_COM/BCG-Staying-theCourse-in-Banking-Mar-2017 tcm9-146794.pdf

7. Larysa Sloboda (2017), Cost-management in correspondent banking relationships. Geopolitics under Globalization, 1(2), 21-33. doi:10.21511/gg.01(2).2017.03

8. Mongid A. (2016), Business efficiency of the commercial banks in ASEAN. Investment Management and Financial Innovations, 13(1), 67-76. Retrieved from https:/ /www.researchgate.net/profile/Abdul_Mongid/ publication/303765386_Business efficiency_of the -

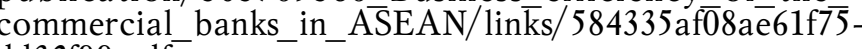
dd32f99.pdf

9. Mongid A. and Muazaroh (2017), The Efficiency and Inefficiency of the Banking Sectors: Evidence From Selected ASEAN Banking. Jurnal Ekonomi Malaysia, Forthcoming edition.

10. Nabil Bello, Aznan Hasan and Buerhan Saiti (2017), The mitigation of liquidity risk in Islamic banking operations. Banks and Bank Systems, 12(3), 154-165. doi:10.21511/bbs.12(3-1).2017.01

11. Rifki, I. (2010). Managing Banking Liquidity Risk in the Current Economic Conditions: A Conceptual Framework. Journal of Management \& Public Policy, 1 (2), $48-64$.

12. Suhartono Suhartono (2017), Productive efficiency of banks in ASEAN countries. Banks and Bank Systems, 12(2), 91-99. doi:10.21511/bbs.12(2).2017.09

\section{References:}

1. Dzubluk, O.V. and Rudan, V.Ya (2016), Upravlinnia likvidnistiu bankivs'koi systemy Ukrainy [Liquidity management of the banking system of Ukraine], Vector, Ternopil, Ukraine.

2. Arif, A. and Anees, A.N. (2012), "Liquidity risk and performance of banking system", Journal of Financial Regulation and Compliance, vol. 20 (2), pp. 182-195.

3. Basel Committee on Banking Supervision (2013), Basel III: The Liquidity Coverage Ratio and liquidity risk monitoring tools, Basel Committee on Banking Supervision, Basel, Switzerland.

4. Dong, Y, Hamilton, R. and Tippett, M. (2014), "Cost efficiency of the Chinese banking sector: A comparison of stochastic frontier analysis and data envelopment analysis", Economic Modelling, vol. 36, pp. 298-308.

5. Franco, F. Marques-Ibanez, D. and Molyneux, P. (2011), "Efficiency and risk in European banking", Journal of Banking \& Finance, vol.35(5), pp. 1315-1326.

6. Grasshoff, G. Mogul, Z. Pfuhler, T. Gittfried, N. Wiegang, C. Bohn, A. and Vonhoff, V. (2017), "Global Risk 2017: Staying the course in banking", available at: http:// image-src.bcg.com/ BCG_COM/BCG-Staying-theCourse-inBanking-Mar-2017_tcm $\overline{9}-146794 . p d f(A c c e s s e d ~ 15$ Oct 2018).

7. Sloboda, L. (2017), "Cost-management in correspondent banking relationships", Geopolitics under Globalization, vol.1(2), pp. $21-33$.

8. Mongid, A. (2016), "Business efficiency of the commercial banks in ASEAN", Investment Management and Financial Innovations, vol.13(1), pp. 67-76.

9. Mongid, A. and Muazaroh, (2017), "The Efficiency and Inefficiency of the Banking Sectors: Evidence From Selected ASEAN Banking", Jurnal Ekonomi Malaysia, Forthcoming edition.

10. Bello, N. Hasan, A. and Saiti, B. (2017), "The mitigation of liquidity risk in Islamic banking operations", Banks and Bank Systems, vol.12(3), pp. 154-165.

11. Rifki, I. (2010), "Managing Banking Liquidity Risk in the Current Economic Conditions: A Conceptual Framework", Journal of Management \& Public Policy, vol. $1(2)$, pp. $48-64$.

12. Suhartono, S. (2017), "Productive efficiency of banks in ASEAN countries", Banks and Bank Systems, vol.12(2), pp. 91-99.

Стаття надійшла до редакиї 31.10.2018 p. 
М.В.Корягін,

д.е.н., професор, професор кафедри бухгалтерського обліку,

Аьвівсъкий торговельний-економічний університет

DOI: $10.32702 / 2306-6806.2018 .11 .27$

\title{
ПОБУАОВА МЕТОАОЛОГІЇ БУХГААТЕРСЬКОГО

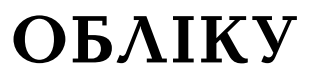

\author{
M. Koryagin, \\ Doctor, Doctor of Economic Sciences, Professor, Prof. the Department of Accounting, \\ Lviv Trade and Economic University
}

\section{CONSTRUCTION OF ACCOUNTING METHODOLOGY}

У Статті запропоновано новий погАяд на визначення структури методологї бухгалтерського обліку, що грунтується на сукупності загальнонаукових; запозичених $з$ інших наук та спеціальних методів, що Становлять СКАаднУ,инамічну Систему з внутрішніми зв'язками. Аоведено недостатність процедурного та адитивного Підходів Аля розкриття змісту облікової методології в Сучасних економічних умовах. Проведено аналіз підходів дослідників до місця і структури методологї бухгал терського обліку як підсистеми системи вищого порядкУ. АосліАЖено проблему процедурного та адитивного підходів до побудови методологї̈ бухгалтерського обліку. Розгяянуто ваЖливість Процедурного ПідходУдо ПобУдови методоАогії бухгал терського обліку, який передбачає виділення груп основних облікових процедур. Аослідже-

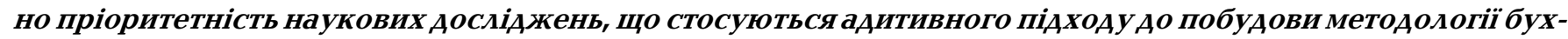
галтерського обліку.

This article represents a new approach to the structure of accounting methodology based on the system of general scientific, borrowed from other sciences and special methods composing a complicated and dynamic structure with intercommunications. It has been proved that procedural and additive approach is insufficient for interpretation of accounting methodology in modern economic conditions. An analysis of the approaches of researchers to the place and structure of the accounting methodology as a subsystem of the higher order system is carried out. The problem of procedural and additive approaches to the construction of the accounting methodology is researched. The importance of the procedural approach to the construction of the accounting methodology, which involves the allocation of groups of basic accounting procedures, is considered. The procedural approach to building a methodology of accounting involves the allocation of groups of basic accounting procedures: observation, measurement, classification, systematization. The priority of scientific researches concerning the additive approach to the construction of the accounting methodology is researched. According to the results of the study of the additive approach, it has been established that the accounting methodology is considered as a set of methods (techniques). The peculiarities of the accounting methodology, which forms the content of the accounting system and determine the nature of its functioning, are determined, affect the process of processing the accounting data and its disclosure in the financial statements. According to the results of the research, it was established that the combination of procedural and additive approaches to the construction of the accounting methodology of accounting is inadequate, since the accounting, methodology should be considered in terms of the system approach, which should have a pronounced "synthetic" nature.

Ключові слова: методологія бухгалтерсъкого обліку, проиедурний підхід, адитивний підхід.

Key words: accounting methodology, procedural approach, additive approach.

\section{ПОСТАНОВКА ПРОБЛЕМИ}

Розвиток бухгалтерського обліку, зміна його ролі в умовах глобалізації економіки є основними причинами перегляду значення бухгалтерського облікуяк в теорії, такі в методології. Однією з передумов до цього $є$ той факт, що період реформування бухгалтерського обліку виявився значно тривалішим, ніж це передбачалося на початковому етапі його розвитку, а проведені зміни в області бухгалтерського обліку поки об'єктивно не оцінені з точки зору їх наслідків та відповідним чином не реалізовані у методології. Ао складу обліково ї методології входять методи обліку, принципи, способи, прийоми, методологічні інструменти, методичні підходи до виконання облікових процедур, що в свойй сукупності забезпечують пізнавальні процеси в системі бухгалтерського обліку.

Методологія бухгалтерського обліку здійснює безпосередній вплив на практику обліку шляхом розвитку та видозміни методів, прийомів, способів та підходів до виконання облікових процедур. Аля забезпечення ефективного функціонування облікової системи, методологічний інструментарій потребує глибокого дослідження і системного визначення. 
У наукових працях спостерігається виділення різних підходів до побудови методології бухгалтерського обліку, що пов'язане з вибором характеру розкриття структури облікової методології та визначення її складових. Автори, як правило, поділяють підходів до побудови методології бухгалтерського обліку на процедурний та адитивний. Кожен 3 них має власну специфіку визначення методологічних складових і розкриття їх змісту.

\section{АНАЛІЗ ОСТАННІХ ДОСЛІДЖЕНЬ І ПУБЛІКАЦІЙ}

Необхідність перегляду місця і структури методології бухгалтерського обліку як підсистеми системи вищого порядку, підтримується сучасними вченими. Аослідженню підходів до побудови методології бухгалтерського обліку присвячені роботи українських вчених М.С. Пушкар [1], М.І. Кутер [2], В.Ф. Палій, Я.В. Соколов [7], Є.В. Мних [4], О.П. Рудановський, О.М. Галаган, С.Ф. Голов [8]. Проте окремі питання щодо підходів до побудови методології бухгалтерського обліку, що стосується його історичного розвитку та становлення залишаються невирішеними.

\section{ПОСТАНОВКА ЗАВДАННЯ}

Метою статті $€$ дослідження змісту процедурного та адитивного підходів до побудови методології бухгалтерського обліку, розкриття характеру їх зміни протягом XX ст., визначення ї впливу на врахування нових інформаційних запитів сучасного економічного середовища.

\section{ВИКЛАД ОСНОВНОГО МАТЕРІАЛУ ДОСЛІДЖЕННЯ}

Процедурний підхід до побудови методології бухгалтерського обліку передбачає виділення груп основних облікових процедур: спостереження, вимірювання, класифікація, систематизація. Спостереження в бухгалтерському обліку є процесом збору та реєстрації фактів, пов'язаних з господарським життям підприємства. Вимірювання відображає процес визначення кількісних значень фактів господарського життя, виражених в грошових одиницях. Класифікація є процесом визначення облікових груп та підгруп в системі об'єктів бухгалтерського обліку за переважаючими ознаками. Систематизація та узагальнення з точки зору бухгалтерського обліку є процесом об'єднання та зведення однорідних груп об'єктів обліку у звітну інформацію.

Процедурний підхід до побудови методології бухгалтерського обліку підтримується значним числом вчених. Зокрема М.С. Пушкар виділяє процеси спостереження, реєстрації, групування, зведення, аналізу та передачі даних [1, с. 39]. M.I. Кутер розглядає в якості методологічних складових процеси спостереження, збору, ідентифікації, оцінки, класифікації, опрацювання та передачі інформації [2, с. 36]. В.Ф. Палій та Я.В. Соколов акцентують увагу на процесах реєстрації, групування та інтерпретації даних (аналізу) [3, с. 47]. Є.В. Мних зміст бухгалтерського обліку розкриває як сукупність процесів спостереження, вимірювання, реєстрації, групування й узагальнення фактів господарської діяльності [4, с. 360].

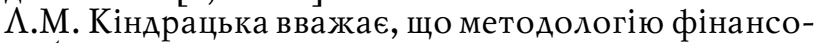
вого обліку можна розглядати як сукупність принципів побудови конкретних методик обліку ... і формування узагальнених показників фінансової звітності. Методологію слід розуміти також як опис логічної системи взаємозв'язаних цілей та понять, що створюють підсистему фінансового обліку та звітності [5, с. 148]. Т.А. Бутинець під методологією бухгалтерського обліку розуміє науку про методи наукового дослідження, тобто знання всієї сукупності прийомів і засобів теоретичного пізнання господарських явищ - об'єктів бухгалтерського обліку з точки зору їх законності, доцільності і достовірності [6, с. 478].
Засновником процедурного підходу до побудови методології бухгалтерського обліку у вітчизняній теорії обліку є О.П. Рудановський. Вчений виділяв в якості основних методологічних процедур реєстрацію, систематизацію, координацію (1925р.) та оцінку (1928р.) [7, c. 465-467]. Iдеї О.П. Рудановського в подальшому розвивалися О.М. Галаганом, який виокремлював в сукупності методів бухгалтерського обліку спостереження, класифікацію, індукцію і дедукцію, синтез та аналіз [7, с. 472]. Разом з тим зазначений підхід не знайшов широкого використання і підтримки серед науковців того часу. Підвищений інтерес дослідників до процедурного підходу почав спостерігатися з 1999 р. ХХ ст. після реформування вітчизняної системи бухгалтерського обліку.

Більшого поширення в теорії бухгалтерського обліку набув адитивний підхід, що підтверджується рядом сучасних вітчизняних вчених, зокрема, у працях С.Ф. Голова [8]. Свою назву адитивний підхід дістав від лат. additivus або additio, тобто такий, що додається. За такого підходу методологію бухгалтерського обліку розглядають як сукупність способів (прийомів). При цьому традиційний набір елементів методу обліку формувався поступово та пройшов низку наукових дискусій.

Розвиток адитивного підходу визначений характером наукової думки радянського періоду. Аослідження наукових праць початку XX ст. показує, що книговидання довоєнних, військових та повоєнних років розкривало наукові дискусії з приводу предмета, задач та методу бухгалтерського обліку. Подібні висновки робить О.Б. Абдалова, досліджуючи теоретичні аспекти оцінки в управлінні підприємством. Зокрема автор зауважує, що радянський період у розвитку бухгалтерського обліку протягом 30-50-х рр. характеризується активним розвитком змісту предмету і методу обліку та елементів, що його складають [9, с. 166].

Проте методологічний напрям в обліковій науці не був тривалим. Починаючи 3 60-х рр. ХХ ст. методологія обліку відходить на другий план. Вченими, які приділяли увагу проблемам облікової методології, переважно здійснювалося поступове введення в науковий обіг того чи іншого методу обліку. Так, А.М. Мозинським [10] у 1938 р. виділявся один елемент методу бухгалтерського обліку - подвійний запис. У 1942 р. П.Н. Василенко у праці "Курс бухгалтерии (для техникумов и курсовой сети)" [11] до складу методів бухгалтерського обліку включав вже чотири елементи: документування, рахунки, подвійний запис та баланс. А.А. Афанасьєв [12] у 1952 р. розширив сукупність елементів методу обліку до шести: документування, оцінка, калькулювання, рахунки, подвійний запис та баланс. Підтримуючи попередні наукові дослідження, Н.В. Аембінський [13] у 1957 р. додає сьомий елемент методу - інвентаризацію, хоча найбільшу вагу приділяє балансу. Набір елементів методу бухгалтерського обліку у складі восьми складових вперше зустрічається у 1959 р. у праці П.Н. Василенко "Основи бухгалтерського обліку" [14] та включає документування, рахунки, подвійний запис, баланс, інвентаризацію, оцінку, калькулювання та звітність. Також вісім елементів методу виділяє А. $\Lambda$. Бикова [15] у своїй праці 1962 р. У подальшому більшість вчених переважно повторює зазначений набір елементів методу.

Паралельні наукові дослідження, що проводились вченими-статистиками також зосереджувались на проблемах методології. Зокрема у "Статистико-економічних нарисах" (1958 р.) академік С.Г. Струмілін зауважує на позитивній ролі уніфікації та стандартизації методів обліку, здійсненої бухгалтерами старої школи [16, с. 11]. Вчений також наголошував на необхідності розвитку практичних аспектів бухгалтерського обліку.

Не дивлячись на існуючу потребу та вимоги практики обліку в розвитку методології, у цілому ряді наукових досліджень ця проблематика не розглядається. Так, О.Ф. Картушин та К.М. Костін (1970р.) [17] розвивають 
проблеми теорії бухгалтерського обліку та висвітлюють завдання обліку, його мету, роль. Казьмін I.С. (1972 р.) [18] зосереджується на порядку організації обліку та процесах документування господарських операцій. Аовідник бухгалтера А.М. Федяєва (1974р.) [19] розкриває заходи з розширення механізації обліку, процес обліку та нормативні документи. Я.М.Б Баренгольц (1975 p.) [20] визначає поняття бухгалтерського обліку, його мету, завдання, наводить зміст системи обліку. Таким чином, протягом тривалого періоду авторами переважно розвивались теоретичні і практичні аспекти бухгалтерського обліку.

3 переходом вітчизняної економіки до ринкових відносин система бухгалтерського обліку почала активно перебудовуватися та адаптуватися до нових інформаційних запитів. Трансформація торкнулася мети, завдань, предмету, об'єктів обліку, змінилася система обліку. Пізніше з прийняттям у 1999 р. Закону України "Про бухгалтерський облік та фінансову звітність в Україні" були задекларовані нові принципи обліку, впроваджений новий план рахунків, форми обліку, затверджений пакет фінансової та податкової звітності. Розвиток системи бухгалтерського обліку з цього моменту набув чіткої орієнтації на інвестиційні потреби.

Не дивлячись на суттєві трансформації в теорії та практиці обліку, його сучасна методологія не відчула суттєвої динаміки і зупинилася на констатації стандартного набору елементів методу. У більшості наукових досліджень авторами приймається за основу вісім елементів методу. Так, Н.А. Канцедах [21] здійснює моделювання взаємодії усталених восьми елементів методу бухгалтерського обліку. Кондратюк $\Lambda$. [22] досліджує функції окремих елементів системи бухгалтерського обліку та базується на класичному восьми-елементному складі методу обліку. Гоголь Т. [23] вивчає методологію бухгалтерського обліку як напрям наукових досліджень в інноваційній економіці та повністю підтримує сформовані елементи облікової методології.

У нових економічних умовах формуються якісно різні інформаційні запити користувачів, які з використанням усталеного набору методів бухгалтерського обліку не можуть бути забезпечені у повній мірі. Відповідно, облікова методологія потребує грунтовно ̈̈ перебудови 3 урахуванням появи нових об'єктів обліку та інвестиційно-орієнтованих економічних рішень.

Побудова методології обліку за адитивним підходом на основі восьми елементів панувала у наукових колах починаючи 350 -х років XX століття і продовжує існувати дотепер. Вважаючи відсутність змін в методології негативним явищем, М.Ю. Мєдвєдєв зауважує, що регламентація операційних даних та способів їх обробки призводить до серйозних втрат [24, с. 107]. За словами автора, діюча методологія, будучи недостатньо еластичною, не дозволяє суб'єкту обліку перебудовуватися залежно від обставин економічного середовища. $\mathrm{O}_{\text {A- }}$ ного разу визначивши облікові прийоми, заздалегідь не передбачається, що з часом може з'явитися новий, більш досконалий прийом, який дозволяє вирішити ту ж проблему швидше та надійніше. Така методологія орієнтується не на кінцевий результат, а на виконання деяких правил, не задаючись питанням відповідають вони чи ні кожному конкретному випадку.

У зв'язку з цим $\Lambda$.О. Чайковська зауважує, що сучасний бухгалтерський облік як складна, внутрішньо диференційована система, яка включає різні компоненти, володіє всіма атрибутами розвинутої науки - специфічною предметною областю, понятійним апаратом, організованим в теорію, набором методів представлення даних, але широта сфери інтересів до інформації, що формується в бухгалтерському обліку, викликає необхідність перегляду його теорії та методології, оскільки відбувається трансформація не тільки форм, але й окремих концептуальних положень теорії бухгалтерського обліку [27, с. 11]. Ця трансформація відбувається шляхом зміни окремих облікових практик, коригування звітних форм, появи нових об'єктів обліку і відносно частих змін нормативної бази.

3 огляду на необхідність розвитку методології, окремими науковцями здійснюються спроби розширити набір елементів методу. Зокрема, А. І. Пільменштейн [25] пропонує доповнити систему методів моделюванням, O.M. Петрук [26] наголошує на необхідності введення плану рахунків як елементу методу обліку. Однак широкої підтримки серед інших науковців такі пропозиції не знайшли.

У ряді сучасних методологічних досліджень адитивний підхід до побудови методології обліку поєднується 3 процесним. Відповідно, в наукових працях спостереження як процес включає в себе прийоми документування та інвентаризації, вартісне вимірювання - оцінку та калькулювання, групування (систематизація) рахунки і подвійний запис, підсумкове узагальнення баланс та звітність.

Таке взаємодоповнення підходів підтримує М.С. Пушкар, на думку якого процедурний підхід не означає відміни адитивного, він може інтегруватися з ним, вказуючи на послідовність процедур та перелік інструментів, завдяки яким можна виконати ці процедури [1, c. 29].

На наш погляд, поєднання процедурного та адитивного підходів до побудови облікової методології $є$ недостатнім. 3 ускладненням економічних зв'язків, появою нових ендогенних та екзогенних факторів впливу, підвищенням рівня ризиковості господарського життя методологія бухгалтерського обліку повинна розглядатися 3 точки зору системного підходу, який має виражений "синтетичний" характер. Системний підхід передбачає розкриття змісту і структури методології бухгалтерського обліку на основі системного аналізу з урахуванням внутрішніх зв'язків елементів, зовнішнього та внутрішнього середовища, змісту окремих елементів системи та особливостей взаємодії між ними.

Як стверджує $\Lambda . О$. Чайковська, призначення методології бухгалтерського обліку як складної, динамічної, цілісної системи способів і прийомів різних рівнів полягає в тому, щоб на основі відповідних принципів (припущень і вимог) забезпечити побудову ефективної системи бухгалтерського обліку, розвиток тих чи інших прийомів обробки облікової інформації [27, с. 14]. Відповідно, виходячи 3 концепції системоутворення методологія бухгалтерського обліку повинна розглядатися в якості самостійної облікової підсистеми. Методологія бухгалтерського обліку як підсистема знахоАиться у стійких зворотних зв'язках з іншими підсистемами загальної облікової системи - теорією та практикою. Визначення характеру і змісту таких зв'язків становить важливе наукове завдання. При цьому слід враховувати, що теорію та методологію обліку потрібно розглядати нерозривно від облікової практики, оскільки наука покликана, в першу чергу, вирішувати практичні потреби бухгалтерів у підготовці достовірної, своєчасної та релевантної інформації для різних груп користувачів.

Методологія багато в чому формує зміст системи бухгалтерського обліку та визначає характер її функціонування, впливає на процес обробки облікових даних та їх розкриття у фінансовій звітності. Зміст системи бухгалтерського обліку та наповнення її підсистем значно змінилося з розпадом СРСР та здобуттям Україною незалежності, що супроводжувалося відмовою від планово-адміністративного типу економічної системи та ринковою орієнтацією, що актуалізувало необхідність реформування системи бухгалтерського обліку.

Процес реформування бухгалтерського обліку у 1990-х рр. ХХ ст. становив значний інтерес більшості вітчизняних науковців. Вийшли в світ праці, присвячені зміні принципів обліку та звітності. Серед них монографія С.Ф. Голова "Бухгалтерський облік в Україні: аналіз 
стану та перспективи розвитку" [8, с. 78-109]. Автор звертав увагу на задекларовану у 1992 р. Указом Президента України № 303 "Про перехід України до загальноприйнятої у міжнародній практиці системи обліку та статистики" від 23.05.1992 р. орієнтацію національної системи бухгалтерського обліку на міжнародні стандарти. Подальші зміни в нормативних документах послідовно підтримували зазначений напрям розвитку бухгалтерського обліку.

Реформування системи бухгалтерського обліку вимагало відповідного перегляду його теоретичних та методологічних основ. Основною метою ведення бухгалтерського обліку згідно ст. 3 Закону України "Про бухгалтерський облік та фінансову звітність в Україні" було встановлено надання інформації зацікавленим користувачам для прийняття управлінських рішень [28]. Відповідно до основної мети трансформувались завдання бухгалтерського обліку, проте методологія обліку практично не зазнала змін. Не дивлячись на поодинокі спроби розширити систему методів, вона в цілому залишилась сталою і на сьогодні не враховує нових вимог користувачів у частині інформації, що формується в обліковому середовищі. Методологія обліку не враховує концепції системності бухгалтерського обліку і не може бути адекватно вбудована в якості його однієї з підсистем.

Необхідність перегляду місця і структури методології бухгалтерського обліку як підсистеми системи вищого порядку, підтримується сучасними вченими. Зокрема М.Ю. Мєдвєдєв вказує, що будь-яка методологія $€$ недосконалою, але недосконалість облікової методології багато в чому визначається тим, що цього можна було б уникнути [24, с. 104]. Найбільшою помилкою є сприйняття облікової методології як глибоко продуманої і логічно обгрунтованої системи, яка має лише незначні недоліки. Навпаки, недоліки облікової методології є всеохоплюючими, хоча кожен 3 них, безумовно, і має свою власну об'єктивну історію виникнення та поширення.

Враховуючи динаміку розвитку методології бухгалтерського обліку як системи, в її структурі слід окремо виділяти методи, інструменти, способи, прийоми, підходи, процедури та принципи. Весь вказаний інструментарій виступає основою для прийняття, обробки, зведення і перетворення облікових даних суб'єктом ведення обліку на інформацію, корисну різним категоріям користувачів.

Центральну складову облікової методології становить сукупність методів бухгалтерського обліку, які забезпечують розвиток інструментарію, за допомогою якого вивчається об'єкт обліку. При цьому слід окремо виділяти такі групи методів, що використовуються бухгалтерським обліком: загальнонаукові; запозичені 3 інших наук; спеціальні (методи, сформовані безпосередньо у середовищі бухгалтерського обліку).

Ао загальнонаукових методів, що використовуються бухгалтерським обліком, відносимо насамперед діалектичний метод, а також моделювання. Групу методів, запозичених з інших наук, складають переважно статистичні методи та методи контролю.Ао основних методів контролю, що активно увійшли до облікового методологічного інструмента рію, відносимо: аналіз, перевірку (звірку), інвентаризацію, спостереження (обстеження).

Як самостійна галузь наукових знань, бухгалтерський облік має власні спеціальні методи, що забезпечують виконання його завдань, дослідження предмета обліку та вивчення об'єктів. Спеціальні методи бухгалтерського обліку, які властиві виключно цій науці, включають документування, оцінку, калькулювання, рахунки і подвійний запис. Вони складаються з елементів, при цьому метод не можна розглядати як сукупність прийомів та способів, їх слід вивчати як систему зі складними багаторівневими зворотними зв'язками.

\section{ВИСНОВКИ}

У сучасних економічних умовах розширення світогосподарських зв'язків у зв'язку з поширенням взаємопроникнення та взаємозалежності економік країн, процесами входження України до світової економіки, збільшенням рівня ризикованості прийняття рішень, необхідністю прискорення обробки та подання облікової інформації, методологія бухгалтерського обліку потребує грунтовної трансформації та видозміни. Окремий розвиток або поєднання процедурного та адитивного підходів до розвитку облікової методології $є$ недостатнім.

Методологічний інструментарій забезпечує обробку суб'єктом ведення обліку інформації про об'єкти, які визначаються предметом бухгалтерського обліку. Перегляд структури методології бухгалтерського обліку дозволяє сформувати динамічну систему, яка весь час розвивається та змінюється під впливом нових запитів користувачів облікової інформації.

Вважаємо, що саме поєднання процедурного та адитивного підходів до побудови облікової методології $€$ недостатнім. Методологія бухгалтерського обліку повинна розглядатися 3 точки зору системного підходу, який повинен мати виражений "синтетичний" характер.

Мітература:

1. Пушкар М.С. Тенденції та закономірності розвитку бухгалтерського обліку в Україні (теоретико-методологічні аспекти): монографія / М.С. Пушкар. - Тернопіль: Економічна думка, 1999. - 422 с.

2. Кутер М.И. Теория и принципы бухгалтерского учета / М.И. Кутер. - М. : Финансы и статистика, 2000. $-544 \mathrm{c}$.

3. Палий В.Ф. АСУ и проблемы теории бухгалтерского учета / В.Ф. Палий, Я.В. Соколов. - М.: Финансы и статистика, 1981. - 224 с.

4. Мних Є. Ао питання визначення методологічних рівнів економічного аналізу / Евген Мних / Економічний аналіз. - 2010. - Вип. 6. - С. 360-362.

5. Кіндрацька $\Lambda . M$. Бухгалтерський облік у банках: методологія і практика / М.М. Кіндрацька. - К.: КНЕУ, 2002. - 286 c.

6. Бутинець Т.А. Аокументування господарських фактів: теорія, методологія, комп'ютеризація/Т.А. Бутинець. - Житомир: ЖITI, 1999. - 412 с.

7. Соколов Я.В. Бухгалтерский учет: от истоков до наших дней: учебн. пособие / Я.В. Соколов. - М.: Аудит, ЮНИТИ, 1996. - 638 с.

8. Голов С. Ф. Бухгалтерський облік в Україні: аналіз стану та перспективи розвитку: монографія / С.Ф. Голов. - К.: Центр учбової літератури, 2007. - 522 с.

9. Абдалова Е.Б. Теоретические аспекты оценки в управлении организацией / Е.Б. Абдалова // Известия Санкт-Петербургского университета экономики и финансов. - 2007. - № 4 - С. $165-168$.

10. Аозинский А.И. Курс теории балансового учета в связи с промышленным, сельскохозяйственным и торговым учетом / А.И. Аозинский. - М.: Союзоргучет, 1938. - $591 \mathrm{c}$.

11. Василенко П.Н. Курс бухгалтерии (для техникумов и курсовой сети) / П.Н. Василенко. - М.: Госпланиздат, 1942. - 304 с.

12. Афанасьев А.А. Основы построения бухгалтерского баланса / А.А. Афанасьев. - 3-е доп. изА-е. - М.: Госфиниздат, 1952. - 168 с.

13. Аембинский Н.В. Теория советского бухгалтерского учета: учеб. пособие / Н.В.Аембинский. - Минск: Редакция научно-технической литературы, 1957. - 312 с.

14. Василенко П.Н. Основы бухгалтерского учета: для подгот. и повышения квалификации бухгалтерои в 3-х вып. Вып. 2. Метод бухгалтерського учета / П.Н. Василенко. - М.: Госпланиздат, 1959.- 147 с.

15. Быкова А.А. Теория бухгалтерського учета/ А.А. Быкова; [под ред. проф. С.А. Щенкова]. - М.: Госфиниздат, $1962 .-352$ c. 
16. Струмилин С.Г. Статистико-экономические очерки / С.Г. Струмилин. - М. : Государственное статистическое издательство, 1958. - 739 с.

17. Костин К.Н. Бухгалтерский учет в районных объединениях и отделениях "Сельхозтехника" / А.Ф. Картушин, К.Н. Костин. - М.: Статистика, 1970. - 376 с.

18. Казьмин И.С. Бухгалтерский учет и отчетность в откормочных хозяйствах / И.С. Казьмин. - М.: Статистика, 1972. - 272 с.

19. Федяев А.М. Справочник бухгалтера савхоза (выпуск III) / А.М. Федяев, А.И. Колчин, С.О. Одеев. - М.: Россельхозиздат, 1974. - 384 с.

20. Баренгольц Я.М. Бухгалтерський облік у сільськогосподарських підприємствах : лабораторно-практичні заняття за журнально-ордерною формою обліку / Я.М. Баренгольц. - К.: Вища школа, 1975. - 224 с.

21. Канцедал Н. А. Моделювання варіантів взаємодії елементів методу бухгалтерського обліку / Н.А. Канцедал // Вісник Запорізького національного університету. Серія "Економічні науки". - 2011. - № 2. - С. $144-149$.

22. Кондратюк $\Lambda$. Функції окремих елементів системи обліку / $\Lambda$. Кондратюк // Економічний аналіз. - 2010. 一 № 6. - С. $81-83$.

23. Гоголь Т. Методологія бухгалтерського обліку як напрямок наукових досліджень в інноваційній економіці / Т. Гоголь // Вісник ТНЕУ. - 2012. — № 2. - С. $151-158$.

24. Медведев М.Ю. Общая теория учета: естественный, бухгалтерский и компьютерный методы / М.Ю. Медведев. - М.: Аело и Сервис, 2001. - 752 с.

25. Пильменштейн А.И. Основы бухгалтерского учета / А.И. Пильменштейн. - М.: Статистика, 1968. - 168 с.

26. Петрук О.М. Гармонізація національних систем бухгалтерського облік: монографія / О.М. Петрук. Житомир: ЖАТУ, 2006. - 420 с.

27. Чайковская $\Lambda$.А. Современные концепции бухгалтерского учета (теория и методология): автореферат дис. на соискание науч. степени А-ра. экон. наук: 08.00.12 / А.А. Чайковская. - М., 2007. - 46 с.

28. Про бухгалтерський облік та фінансову звітність в України: закон України від 16.07.1999 р. № 996-XIV: [Електронний ресурс]. - Режим доступу: http://zakon4.rada.gov.ua/laws/show/996-14

\section{References:}

1. Pushkar, M.S. (1999), Tendentsii ta zakonomirnosti rozvytku bukhhalters'koho obliku v Ukraini (teoretykometodolohichni aspekty) [Trends and regularities of accounting development in Ukraine (theoretical and methodological aspects)], Ekonomichna dumka, Ternopil, Ukraine.

2. Kuter, M.I. (2000), Teorija i principy buhgalterskogo ucheta [Theory and Principles of Accounting], Finansy i statistika, Moscow, Russia.

3. Palij, V.F. (1981), ASU i problemy teorii buhgalterskogo ucheta [ACS and problems of the theory of accounting], Finansy i statistika, Moscow, Russia.

4. Mnykh, Ye. (2010), "To the question of determining the methodological levels of economic analysis", Ekonomichnyj analiz, vol. 6, pp. 360-362.

5. Kindrats'ka, L.M. (2002), Bukhhalters'kyj oblik u bankakh: metodolohiia i praktyka [Accounting in banks: methodology and practice], KNEU, Kyiv, Ukraine.

6. Butynets', T.A. (1999), Dokumentuvannia hospodars'kykh faktiv: teoriia, metodolohiia, komp'iuteryzatsiia [Documentation of economic facts: theory, methodology, computerization], ZhITI, Zhytomyr, Ukraine.

7. Sokolov, Ja.V. (1996), Buhgalterskij uchet: ot istokov do nashih dnej [Accounting: from the beginnings to the present day], Audit, JuNITI, Moscow, Russia.

8. Holov, S.F. (2007), Bukhhalters'kyj oblik v Ukraini: analiz stanu ta perspektyvy rozvytku [Accounting in Ukraine: Analysis of the Status and Prospects of Development], Tsentr uchbovoi literatury, Kyiv, Ukraine.
9. Abdalova, E.B. (2007) "Theoretical aspects of evaluation in managing an organization", Izvestija SanktPeterburgskogo universiteta jekonomiki i finansov, vol. 4, pp. 165-168.

10. Lozinskij, A.I. (1938), Kurs teorii balansovogo ucheta v svjazi s promyshlennym, sel'skohozjajstvennym i torgovym uchetom [The theory of balance accounting in connection with industrial, agricultural and trade accounting], Sojuzorguchet, Moscow, Russia.

11. Vasilenko, P.N. (1942), Kurs buhgalterii (dlja tehnikumov i kursovoj seti) [Accounting course (for technical schools and course network)], Gosplanizdat, Moscow, Russia.

12. Afanas'ev, A.A. (1952), Osnovy postroenija buhgalterskogo balansa [Basics of building a balance sheet], 2nd ed, Gosplanizdat, Moscow, Russia.

13. Dembinskij, N.V. (1957), Teorija sovetskogo buhgalterskogo ucheta [Theory of Soviet Accounting], Redakcija nauchno-tehnicheskoj literatury, Minsk, Belarus.

14. Vasilenko, P.N. (1959). Osnovy buhgalterskogo ucheta: dlja podgot. i povyshenija kvalifikacii buxgaltepoi v 3-x vyp. Vyp. 2. Metod buhgalters'kogo ucheta [Basics of accounting: for preparatory. and advanced accounting in 3 vol. Issue 2. Accounting method], Gosplanizdat, Moscow, Russia.

15. Bykova, A.L. and Shhenkova, S.A. (1962). Teorija buhgalters'kogo ucheta [Accounting Theory], Gosfinizdat, Moscow, Russia.

16. Strumilin, S.G. (1958), Statistiko-jekonomicheskie ocherki [Statistical and Economic Essays], Gosudarstvennoe statisticheskoe izdatel'stvo, Moscow, Russia.

17. Kostin, K.N. (1970). Buhgalterskij uchet v rajonnyh objedinenijah i otdelenijah "Sel'hoztehnika" [Accounting in regional associations and branches of "Agricultural machinery"], Statistika, Moscow, Russia.

18. Kaz'min, I.S. (1972). Buhgalterskij uchet i otchetnost' v otkormochnyh hozjajstvah [Accounting and reporting in fattening farms], Statistika, Moscow, Russia.

19. Fedjaev, A.M. Kolchin, A. I. and Odeev, S. O. (1974). Spravochnik buhgaltera savhoza (vypusk III) [Reference book of the state farm accountant (issue III)], Rossel'hozizdat, Moscow, Russia.

20. Barenhol'ts, Ya.M. (1975). Bukhhalters'kyj oblik u sil's'kohospodars'kykh pidpryiemstvakh [Accounting area in the city], Vyscha shkola, Kyiv, Ukraine.

21. Kantsedal, N.A. (2011), "Modeling options for interaction between elements of the accounting method", Visnyk Zaporiz'koho natsional'noho universytetu. Seriia "Ekonomichni nauky", vol. 2, pp. 144-149.

22. Kondratiuk, L. (2010), "Functions of separate elements of the accounting system", Ekonomichnyj analiz, vol. 6 , pp. $81-83$.

23. Hohol', T. (2012), "Accounting methodology as a direction of scientific research in the innovative economy", Visnyk TNEU, vol. 2, pp. 151-158.

24. Medvedev, M.Ju. (2001). Obshhaja teorija ucheta: estestvennyj, buhgalterskij i komp'juternyj metody [General theory of accounting: natural, accounting and computer methods], Delo i Servis, Moscow, Russia.

25. Pil'menshtejn, D.I. (1968). Osnovy buhgalterskogo ucheta [Basics of Accounting], Statistika, Moscow, Russia.

26. Petruk, O.M. (2006). Harmonizatsiia natsional'nykh system bukhhalters'koho obliku [Harmonization of national accounting systems], ZhDTU, Zhytomyr, Ukraine.

27. Chajkovskaja, L.A. (2007), "Contemporary Accounting Concepts (Theory and Methodology)", Doctor of Economics, Thesis, Accounting, statistics, Russian Academy of Economics named after G.V. Plekhanov, Moscow, Russia.

28. The Verkhovna Rada of Ukraine (1999), The Law of Ukraine "On Accounting and Financial Reporting in Ukraine", available at: http://zakon4.rada.gov.ua/laws/ show/ 996-14 (Accessed 03 Nov 2018).

Стаття надійшла до редакиї 07.11.2018 p. 


\title{
ЕКОНОМІЧНА НАУКА
}

УАК 332.12

H.O. Петренко,

д.е.н., дочент, завідувач кафедри публічного управління та адміністрування,

Умансъкий начіональний університет садівництва, м. Умань

DOI: $10.32702 / 2306-6806.2018 .11 .32$

\section{ФОРМУВАННЯ ПРОМИСАОВОГО ПОТЕНЦІААУ УКРАЇНИ: РЕГІОНАЛЬНИЙ АНАЛІЗ}

\author{
N. Petrenko, \\ Doctor of Economic Sciences, Associate professor, Head of the Department of Public Management \\ and Administration, Uman National University of Horticulture, Uman
}

FORMATION OF INDUSTRIAL POTENTIAL OF UKRAINE: REGIONAL ANALYSIS

Устатті проведено регіональний комплексний аналіз формування та використання промислового потенціалу України. У процесі дослідження з'ясовано, що промисловий комплекс є фундаментом господарської системи країни. Орієнтація економічної політики на регіональний промисловий розвиток зумовлює зростання практично всіх секторів економіки. Саме рівень, Структура та динамізм промислового виробництва визначають економічні можливості регіону.

Уході, ослідження проаналізовано теоретичні положення та методологічні підходи до визначення поняття "Промисловий потенціал". Виокремлено скАадові Промислового потенціалу регіонУ, вказано на ресурси їх формування та характеристику. Визначено, що промисловий потенціал регіону залежить віА рівня розвитку матеріально-технічної, інноваційної, інвестиційної, трудової, інфраструктурної, фінанСової СкАадових. Виокремлено показники стану Структурних компонент промислового потенціалу регіону. Проведено розрахунок промислового потенціалу на регіональному рівні. Визначено фактори, що перешкоджають розвитку промислового потенціалу.

У ПідсумкУ зазначено, що дАя усунення проблем, що гальмують розвиток промислового потенціалу регіону, необхідним є формування промислової політики, яка б відповідала сучасним економічним Умовам, і була спрямована, на підвищення техніко-технологічного рівня виробничої діяльності промислових підприемств.

In article was conducted the regional complex analysis of the formation and use of industrial potential of Ukraine. In the process of research was found out that the industrial complex is the foundation of the economic system of the country. The growth of virtually all sectors of the economy, determines the orientation of economic policy to regional industrial development. It is the level, structure and dynamics of industrial production that determines the economic potential of the region. The economic independence of the region and the focus on selfsufficiency have led to the need to create fundamentally new mechanisms for the management and development of industry. Under such conditions, to create for the qualitative industrial growth of the regional economy, the actual task is to assess the industrial potential of the region, the degree of use, the possibility and necessity of its increase.

During in research been analyzed the theoretical positions and methodological approaches to the definition of "industrial potential". The components of industrial potential of the region are singled out, the resources of their formation and characterization are indicated. It is determined that the industrial potential of the region depends on the level of development of material, technical, innovation, investment, labor, infrastructure, financial components. The indicators of the state of structural components of the industrial potential of the region are singled out. The calculation of industrial potential at the regional level is carried out. The factors hindering development of industrial potential are determined. Considering the results of a regional study regarding the formation of industrial potential, it should be noted that the industrial potential of the regions of Ukraine is not used to the fullest extent. For development of industry in the region is hampered by low indicators of development of material, technical, innovation, investment, labor, infrastructure, financial components, which determine its industrial potential. 
As a result, it is stated that in order to eliminate the problems hindering the development of the industrial potential of the region, it is necessary to formulate industrial policy, which will meet modern economic conditions, and was aimed at increasing the technical and technological level of industrial activity of industrial enterprises.

Ключові слова: промисловість, потениіал, регіон, ресурси, економіка, політика.

Key words: industry, potential, region, resources, economy, politics.

\section{ПОСТАНОВКА ПРОБЛЕМИ}

3 нестабільних макро- та мікроекономічних умов розвитку економіки України досягнення поставлених цілей модернізації і перехід на інноваційний шлях розвитку безпосередньо залежать від розвитку промислового сектора регіону. Економічна незалежність регіону і орієнтація на самозабезпечення призвели до необхідності створення принципово нових механізмів управління та розвитку промисловості. За таких умов, для створення умов якісного промислового зростання регіональної економіки, актуальним завданням є оцінка промислового потенціалу регіону, ступінь використання, можливість і необхідність його нарощування. Рішення даного завдання дасть змогу визначити проблеми, що заважають забезпечити відповідний внесок промисловості у формування стратегічної конкурентоспроможності регіону, а також визначити перспективи його розвитку.

\section{АНАЛІЗ ОСТАННІХ ДОСЛІДЖЕНЬ І ПУБЛІКАЦІЙ}

Теоретико-методологічним аспектам дослідження потенціалу на регіональному рівні присвячено чимало економічних досліджень, зокрема у роботах: Біянчі П. [9], Каплан Р.С. [4], Аабори С. [9], Нікітаєвої А.Ю. [5], Нортона А.П. [4], Свинцової А.П. [6] визначено поняття промислового потенціалу, сформовано систему показників стратегічного розвитку, окреслено інституційну структура регіону в контексті інноваційного развитку промисловості. У працях Беррі К. [10], Аація О.I. [1], Аикого О.В. [3] надано оцінку рівню реалізації потенціалу регіону, визначено основні пріоритети та механізми стратегічного планування соціально-економічного розвитку регіонів. Концепції, положення, висновки і рекомендації, висвітлені працях указаних авторів, створили міцний теоретико-методологічний фундамент і посідають вагоме місце у вирішенні проблем стратегічного розвитку промислової галузі, впровадження та реалізації регіональної інноваційної політики тощо.

\section{НЕВИРІШЕНІ ЧАСТИНИ ПРОБЛЕМИ}

Актуалізація питань щодо формування промислового потенціалу України активізувала відповідні досліАження в дцьому напрямі, основним завданням яких, є визначення основ інноваційного розвитку та управління промисловістю на регіональному рівні. Вивчення наукових літературних джерел щодо цієї проблеми показало існування значних розбіжностей у визначенні пріоритетних напрямів розвитку промислової галузі, зокрема у напрямку специфіки реформування та використання окремих підгалузей промислового комплексу. Тому, аналітичні питання щодо ролі та специфіки формування і використання промислового потенціалу для розвитку регіонів України, вимагають проведення подальших теоретико-практичних розвідок у даному напрямі.

\section{META CTATTI}

Метою статті $€$ проведення регіонального комплексного аналізу формування та використання промислового потенціалу України.

Зважаючи на мету статті, завданнями дослідження є: аналіз теоретичних положень та методологічних підходів до визначення поняття "промисловий потенціал"; виокремлення складових промислового потенціалу регіону; визначення показників стану структурних компонент промислового потенціалу регіону; розрахунок промислового потенціалу на регіональному рівні; визначення факторів, що перешкоджають розвитку промислового потенціалу на державному та регіонахьному рівнях.

\section{ВИКЛАД ОСНОВНОГО МАТЕРІАЛУ}

Промисловий комплекс $є$ фундаментом господарської системи країни. Орієнтація економічної політики на регіональний промисловий розвиток зумовлює зростання практично всіх секторів економіки. Практика окремих промислово розвинених країн свідчить про те, що і при обмеженості природних ресурсів можна мати високорозвинений економічний потенціал, якщо він грунтується на прогресивному і ефективному виробництві. Саме рівень, структура, динамізм промислового виробництва визначають економічні можливості регіону. Промислова сфера забезпечує всі галузі економіки засобами виробництва. Варто зазначити, що дослідження промислового потенціалу на регіональному рівні не отримало широкого поширення. Однак можна виділити ряд робіт, в яких розглядаються питання визначення та розвитку промислового потенціалу регіону. Так, Свинцова А.П. під промисловим потенціалом регіону розуміють сукупну здатність підприємств регіону створювати і виробляти конкурентоспроможну продукцію, просувати іiі на ринку, вигідно реалізовувати і забезпечувати необхідний рівень обслуговування [6]. Найважливішим напрямком розвитку промислового потенціалу є його оновлення, технологічна модернізація, прискорений розвиток галузей, найбільш передових в технологічному відношенні. Аля регіональної економіки головним $є$ розвиток місцевої промисловості, яка відіграє важливу роль у створенні робочих місць, задоволенні внутрішнього попиту, сприяє комплексному розвитку території. Аацій O.I. під промисловим потенціалом розуміє інтегральну кількісну оцінку максимально можливої результативності використання ресурсів промисловими підприємствами відповідно до укладених контрактів в умовах раціональної організації і кооперування виробництва господарюючих суб'єктів, розташованих на відповідній території [1, с. 336]. Промисловий потенціал, значною мірою забезпечує формування валової доданої вартості, характеризується наявністю певної пропорційності і взаємозв'язками між його складовими [3]. При цьому пропорції являють собою своєрідний "каркас" промислового розвитку, а процеси трансформації цих пропорцій слугують умовою реалізації промислових стратегій. Зважаючи на проведений аналіз щодо виз-

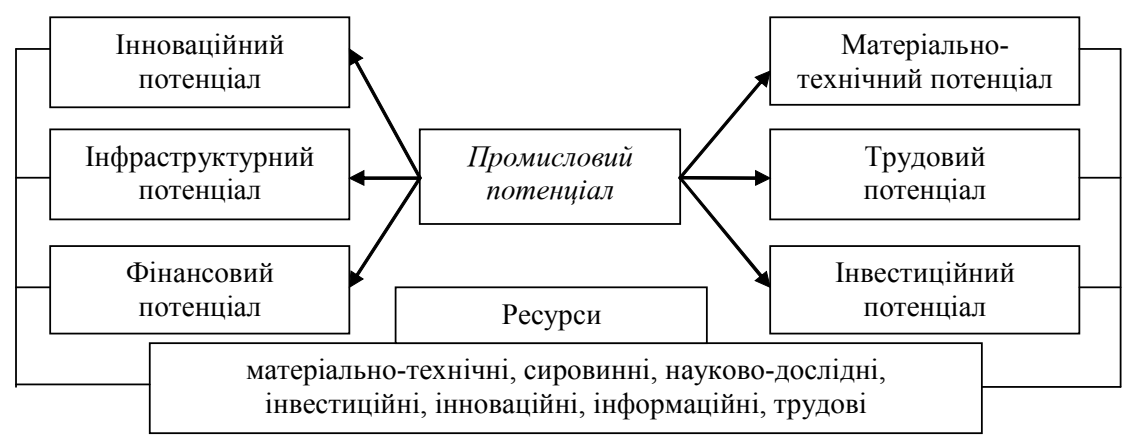

Рис. 1. Складові промислового потенціалу регіону

Ажерело: складено автором на основі поведеного аналізу. 
Таблиця 1. Компоненти промислового потенціалу регіону

\begin{tabular}{|l|l|}
\hline \multicolumn{1}{|c|}{ Вид потенціалу } & \multicolumn{1}{c|}{ Характеристика } \\
\hline технічний & $\begin{array}{l}\text { Основні фонди, які утворюють матеріально-технічний } \\
\text { потенціал промисловості регіону, наявні на підприємствах } \\
\text { прогресивні технологічні підрозділи, процеси, унікальні } \\
\text { технології }\end{array}$ \\
\hline Інноваційний & $\begin{array}{l}\text { Сукупність: інноваційно активних підприємств, } \\
\text { висококваліфікованих кадрів, здатних генерувати й } \\
\text { реалізовувати нові технічні ідеї; наявність фінансових коштів, } \\
\text { що спрямовуються на технологічні інновації, з метою } \\
\text { забезпечення підвищення техніко-технологічного рівня } \\
\text { виробничої діяльності }\end{array}$ \\
\hline Фінансовий & $\begin{array}{l}\text { Сукупні фінансові можливості промисловості, що забезпечують } \\
\text { операційну діяльність промисловості, розвиток виробничої } \\
\text { інфраструктури, а також сприяють вирішенню нагальних } \\
\text { завдань і досягнення поставлених економічних цілей }\end{array}$ \\
\hline Трудовий & $\begin{array}{l}\text { Можливість використання трудових ресурсів території для } \\
\text { виконання завдань виробництва, що забезпечують створення } \\
\text { готових продуктів }\end{array}$ \\
\hline Інфраструктурний & $\begin{array}{l}\text { Сукупні можливості території, що забезпечують умови для } \\
\text { ефективного функціонування виробництва, обігу товарів і } \\
\text { життєдіяльності людей в процесі оптимальної взаємодії із } \\
\text { навколишнім середовищем і раціонального використання } \\
\text { ресурсів }\end{array}$ \\
\hline Інвестиційний & $\begin{array}{l}\text { Можливість і готовність потенційних інвесторів інвестувати в } \\
\text { розвиток регіональної промисловості }\end{array}$ \\
\hline
\end{tabular}

Ажерело: складено автором на основі проведеного аналізу. начення поняття "промисловий потенціал", слід зазначити, що промисловий потенціал характеризує сукупні здібності і можливості підприємств території, які можуть бути реалізовані при наявності ресурсів. Сукупні наявні ресурси в свою чергу характеризують виробничо-економічну діяльність підприємств і формують систему потенціалів нижчого порядку.

Розглянувши теоретико-методологічні підходи до визначення промислового потенціалу $[1 ; 3 ; 4 ; 6]$, слід зазначити, що він є однією 3 головних складових економічного потенціалу регіону, впливає на рівень розвитку продуктивних сил суспільства і є сукупністю можливостей промислових підприємств регіону.

На основі класифікації факторів виробництва, в якості складових промислового потенціалу, слід виділити матеріально-технічний, інноваційний, інвестиційний, трудовий, інфраструктурний, фінансовий потенціали, які в свою чергу формуються на основі сировинних, промислових, науково-дослідних, інноваційних, інвестиційних, трудових та інформаційних ресурсів (рис. 1).

Характеристика компонент промислового потенціалу подано в таблиці 1.

Таблиця 2. Основні показники, що визначають промисловий потенціал регіону

\begin{tabular}{|c|c|c|}
\hline Показник & Од. вим. & Параметр промислового потенціалу \\
\hline \multicolumn{3}{|c|}{ Компонента 1. Матеріально-технічний потенціал } \\
\hline $\begin{array}{l}\text { 1.1. Вартість основних фондів (ОФ) промисловості на } \\
\text { душу населення }\end{array}$ & грн & $\begin{array}{l}\text { Показник забезпеченості ОФ промисловості } \\
\text { регіону }\end{array}$ \\
\hline 1.2. Ступінь зношеності основних фондів промисловості & $\%$ & Характеристика стану виробничих ресурсів \\
\hline 1.3. Фондовіддача & - & $\begin{array}{l}\text { Ефективність використання основних } \\
\text { виробничих фондів }\end{array}$ \\
\hline \multicolumn{3}{|c|}{ Компонента 2. Інноваційний потенціал } \\
\hline 2.1. Відсоток інноваційно активних підприємств & $\%$ & $\begin{array}{l}\text { Можливості промислових підприємств } \\
\text { упроваджувати інноваційну продукцію }\end{array}$ \\
\hline $\begin{array}{l}\text { 2.2. Частка відвантаженої інноваційної продукції в } \\
\text { загальному обсязі відвантаженої продукції } \\
\text { промисловості }\end{array}$ & $\%$ & Рівень інноваційного розвитку промисловості \\
\hline $\begin{array}{l}\text { 2.3. Частка витрат на технологічні інновації від } \\
\text { загального обсягу інвестицій в промисловості }\end{array}$ & $\%$ & $\begin{array}{l}\text { Рівень пріоритетності завдань технологічного } \\
\text { розвитку промисловості }\end{array}$ \\
\hline $\begin{array}{l}\text { 2.4. Кількість персоналу, який задіяно в дослідженнях і } \\
\text { конструкторських розробках, в розрахунку на тисячу } \\
\text { зайнятих у промисловості }\end{array}$ & чол. & $\begin{array}{l}\text { Рівень ефективності науково-інноваційної сфери } \\
\text { в промисловості }\end{array}$ \\
\hline \multicolumn{3}{|c|}{ Компонента 3. Фінансовий потенціал } \\
\hline $\begin{array}{l}\text { 3.1. Частина прибуткових організацій промисловості в } \\
\text { загальній кількості промислових підприємств } \\
\end{array}$ & $\%$ & $\begin{array}{l}\text { Рівень ефективності функціонування } \\
\text { промисловості регіону }\end{array}$ \\
\hline $\begin{array}{l}\text { 3.2. Сальдований фінансовий результат промислових } \\
\text { підприємств на } 1 \text { грн основних виробничих фондів }\end{array}$ & грн. & $\begin{array}{l}\text { Рівень фінансових можливостей для розвитку } \\
\text { промисловості }\end{array}$ \\
\hline 3.3. Рентабельність активів промислових підприємств & $\%$ & $\begin{array}{l}\text { Ефективність використання активів промислових } \\
\text { підприємств з метою отримання прибутку }\end{array}$ \\
\hline \multicolumn{3}{|c|}{ Блок 4. Трудовий потенціал } \\
\hline $\begin{array}{l}\text { 4.1. Питома вага виробничо-промислового персоналу в } \\
\text { загальній кількості зайнятих в економіці }\end{array}$ & $\%$ & Кадровий ресурс промисловості \\
\hline $\begin{array}{l}\text { 4.2. Частина фахівців з вищою освітою в загальній } \\
\text { кількості промислового персоналу }\end{array}$ & $\% \%$ & $\begin{array}{l}\text { Ресурс висококваліфікованих робітничих кадрів } \\
\text { промисловості }\end{array}$ \\
\hline $\begin{array}{l}43 . \text { Частина випущених фахівців } 3 \text { середньою } \\
\text { професійною освітою в загальній кількості зайнятих }\end{array}$ & $\%$ & Інтелектуальний ресурс промисловості \\
\hline \multicolumn{3}{|c|}{ Компонента 5. Інфраструктурний потенціал } \\
\hline $\begin{array}{l}\text { 5.1. Густота залізничних колій загального користування, } \\
\text { кілометрів на } 1000 \text { кв. км території км }\end{array}$ & Км & \multirow[t]{2}{*}{ Щільність транспортної інфраструктури } \\
\hline $\begin{array}{l}\text { 5.2. Густота автомобільних доріг з твердим покриттям, } \\
\text { кілометрів доріг на } 1000 \text { кв. км території км } \\
\end{array}$ & Км & \\
\hline $\begin{array}{l}\text { 5.3. Наявність індустріальних і технопарків з вільними } \\
\text { площами і готовими інфраструктурними об'єктами (газ, } \\
\text { електроенергія, вода, каналізація) га }\end{array}$ & & $\begin{array}{l}\text { Забезпеченість регіону інфраструктурою і } \\
\text { необхідними адміністративно-правовими } \\
\text { умовами для розміщення нових виробництв }\end{array}$ \\
\hline \multicolumn{3}{|c|}{ Компонента 6. Інвестиційний потенціал } \\
\hline $\begin{array}{l}\text { 6.1. Обсяг інвестицій в основний капітал промисловості } \\
\text { в розрахунку на душу населення }\end{array}$ & & $\begin{array}{l}\text { Характеристика інвестицій, що спрямовані на } \\
\text { модернізацію і розвиток промисловості }\end{array}$ \\
\hline $\begin{array}{l}\text { 6.2. Частка банківських інвестицій в загальному обсязі } \\
\text { інвестицій в промисловість }\end{array}$ & $\%$ & $\begin{array}{l}\text { Рівень ефективності залучення банківського } \\
\text { капіталу }\end{array}$ \\
\hline $\begin{array}{l}\text { 6.3. Частка інвестицій в машини, обладнання та } \\
\text { транспортні засоби від загального обсягу інвестицій в } \\
\text { основний капітал промислових підприємств }\end{array}$ & $\%$ & Частка вкладень у власні виробничі активи \\
\hline
\end{tabular}

Ажерело: складено автором на основі проведеного аналізу. 
У таблиці 2 наведено показники стану структурних компонент промислового потенціалу регіону.

Промисловий потенціал регіону залежить, перш за все, від стану та ефективності використання основних виробничих фондів (матеріальнотехнічного потенціалу). Аналіз динаміки цих показників в регіонах за період $32010-2017$ рр. дає змогу зробити висновки про істотне збільшення вартості основних фондів. У середньому цей показник виріс у 3,4 рази. Найбільший приріст зафіксовано в Київській області - більш ніж у 4 рази. Однак принципового значення набуває їх стан. Статистичні дані свідчать про збільшення рівня зношення основних виробничих фондів. Так, за досліджуваний період цей показник збільшився у Вінницькій області на $14,9 \%$, Кіровоградській - на $9,9 \%$, Черкаській - на 7,9\%, Волинській - на 6,3\%, а за підсумками 2017 р. рівень зношеності основних виробничих фондів Одеської області склав 48,3\% [2]. Ефективність використання основних виробничих фондів визначається показниками фондовідаачі. Аналіз їі динаміки по регіонах України показує, що найбільш ефективно основні фонди використовуються в Київській області.

У Вінницькій області ефективність використання основних виробничих фондів істотно знизилася з 2,35 у 2010 до 1,5 у 2017 р. [8] (табл. 3).

В умовах конкурентної боротьби і відкритості ринку важливе значення має інноваційний потенціал промислового сектора. Слід зауважити, що рівень інноваційної активності в цілому по країні та областях у 2017 р. залишається

досить низьким (10,3\% і 11,0\% відповідно). Наприклад, питома вага промислових підприємств Черкаської області, що здійснюють інноваційні розробки і впроваджують їх у виробництві, за той же період складає менше $8 \%$, тобто входить до групу областей 3 низьким рівнем інноваційної активності [2]. В результаті частка інноваційної продукції в загальному обсязі реалізованої продукції вкрай мала. В Україні у 2017 р. цей показник досяг лише 7,5\%, в середньому по областях ще мен- ів фондовіддачі по областях України за період 2010-2017 pp.

\begin{tabular}{|c|c|c|c|c|c|c|c|c|c|c|}
\hline \multirow[b]{2}{*}{ Область } & \multicolumn{8}{|c|}{ Роки, \% } & \multirow{2}{*}{$\begin{array}{c}\text { Зміни } \\
2014-2010 \text { pp., } \\
\text { млн грн } \\
\end{array}$} & \multirow{2}{*}{\begin{tabular}{|c|} 
Зміни \\
2017-2014 pp., \\
млн грн \\
\end{tabular}} \\
\hline & 2010 & 2011 & 2012 & 2013 & 2014 & 2015 & 2016 & 2017 & & \\
\hline Київська & 1,72 & 2,19 & 2,83 & 2,98 & 2,33 & 2,64 & 2,79 & 2,45 & 0,74 & $-0,53$ \\
\hline Вінницька & 2,35 & 2,20 & 1,97 & 2,40 & 1,49 & 1,77 & 1,93 & 1,50 & $-0,85$ & $-0,90$ \\
\hline Черкаська & 1,24 & 1,27 & 1,44 & 1,50 & 1,16 & 1,42 & 1,75 & 1,45 & 0,21 & $-0,05$ \\
\hline Кіровоградська & 1,46 & 1,32 & 1,29 & 1,46 & 1,16 & 1,36 & 1,44 & 1,41 & $-0,05$ & $-0,05$ \\
\hline Волинська & 1,39 & 1,32 & 1,38 & 1,36 & 0,98 & 1,17 & 1,21 & 1,07 & $-0,32$ & $-0,29$ \\
\hline Миколаївська & 1,10 & 1,24 & 1,14 & 1,28 & 1,15 & 1,15 & 1,17 & 0,98 & $-0,12$ & $-0,30$ \\
\hline Одеська & 1,23 & 1,09 & 0,94 & 0,92 & 0,83 & 0,78 & 0,86 & 0,93 & $-0,29$ & 0,01 \\
\hline Закарпатська & 1,13 & 1,13 & 1,12 & 1,14 & 1,00 & 1,29 & 0,80 & 0,78 & $-0,35$ & $-0,36$ \\
\hline Харківська & 1,05 & 0,92 & 1,01 & 0,81 & 0,77 & 0,81 & 0,78 & 0,72 & $-0,34$ & $-0,10$ \\
\hline Чернігівська & 1,32 & 1,43 & 1,45 & 1,43 & 1,09 & 1,21 & 1,25 & 1,20 & $-0,12$ & $-0,23$ \\
\hline Хмельницька & 1,43 & 1,43 & 1,41 & 1,46 & 1,33 & 1,46 & 1,48 & 1,40 & $-0,03$ & $-0,06$ \\
\hline Львівська & 1,64 & 1,71 & 1,66 & 1,74 & 2,00 & 2,20 & 2,27 & 2,26 & 0,62 & 0,52 \\
\hline
\end{tabular}

Ажерело: побудовано автором на основі аналізу даних [2; 8]. областях України за період 2010-2017 рр.

\begin{tabular}{|c|c|c|c|c|c|c|c|c|c|c|}
\hline \multirow{2}{*}{ Область } & \multicolumn{8}{|c|}{ Роки, млн грн } & \multirow{2}{*}{$\begin{array}{c}\text { Зміни } \\
2014-2010 \text { pp., } \\
\%\end{array}$} & \multirow{2}{*}{$\begin{array}{c}\text { Зміни } \\
2017-2014 \text { pp., } \\
\%\end{array}$} \\
\hline & 2010 & 2011 & 2012 & 2013 & 2014 & 2015 & 2016 & 2017 & & \\
\hline Київська & 0,3 & 0,2 & 0,1 & 0,1 & 0,3 & 0,4 & 0,2 & 6,8 & 6,5 & 6,7 \\
\hline Вінницька & - & 0,9 & 5,3 & 4,5 & 0,6 & 2,9 & 7,6 & 5,7 & - & 1,2 \\
\hline Черкаська & 4,4 & 6,0 & 8,0 & 6,5 & 2,7 & 1,6 & 3,6 & 4,0 & $-0,4$ & $-2,5$ \\
\hline Кіровоградська & 16,6 & 6,4 & 8,6 & 9,8 & 7,3 & 6,3 & 4,2 & 2,9 & $-13,7$ & $-6,9$ \\
\hline Волинська & 0,7 & 1,3 & 0,9 & 1,2 & 1,2 & 2,0 & 1,5 & 1,5 & 0,8 & 0,3 \\
\hline Миколаївська & 0,5 & 0,3 & 0,4 & 1,3 & 1,4 & 2,2 & 2,1 & 0,8 & 0,3 & $-0,5$ \\
\hline Одеська & 0,3 & 0,5 & 0,3 & 0,6 & 1,9 & 1,0 & 0,2 & 0,3 & 0,0 & $-0,3$ \\
\hline Закарпатська & 6,8 & 5,1 & 7,8 & 6,4 & 2,4 & 0,1 & 0,1 & 0,2 & $-6,6$ & $-6,2$ \\
\hline Харківська & 3,0 & 0,3 & 0,2 & 0,2 & 0,3 & 0,4 & 0,1 & 0,1 & $-2,9$ & $-0,1$ \\
\hline Чернігівська & 4,0 & 4,3 & 4,7 & 4,5 & 4,2 & 4,3 & 6,0 & 7,5 & 3,5 & 3,0 \\
\hline Хмельницька & 2,8 & 3,9 & 3,7 & 3,4 & 2,8 & 3,4 & 4,4 & 6,0 & 3,2 & 2,6 \\
\hline Львівська & 2,4 & 7,5 & 3,2 & 2,7 & 4,5 & 5,8 & 7,0 & 10,0 & 7,6 & 7,3 \\
\hline
\end{tabular}

Ажерело: побудовано автором на основі аналізу даних [7].

ше - 6,0\%. Незважаючи на те, що у вартісному вираженні обсяг реалізованої інноваційної продукції в Черкаській області зріс на 6486,3 млн грн, склавши за 2017 рік 16593,1 млн грн, а загалом її частка в загальному обсязі не перевищує 4\% (табл. 4).

Слід вказати на збільшення витрат у 2017 р. на технологічні інновації по Україні та областях становить 8,5 і 7,5 порівняно з 2016 р. Найбільшу частку коштів у 2017 р. в технологічні інновації вкладали підприємства

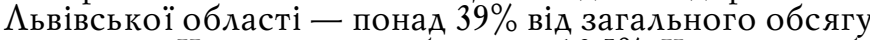
інвестицій, Чернігівської області - 12,5\%, Київської області - 11,5\%. Однак у Черкаській області спостерігається скорочення даного показника. У 2017 р. обсяг витрат склав 1358,8 млн грн, що на 448,1 млн грн менше рівня 2015 р. і на 1285 млн грн менше рівня 2014 р. Таким чином, частка витрат на технологічні інновації від загального обсягу інвестицій, що спрямовуються в про-

Таблиця 5. Частка витрат на технологічні інновації від загального обсягу інвестицій в промисловості по областях України за період 2010-2017 рр.

\begin{tabular}{|c|c|c|c|c|c|c|c|c|c|c|}
\hline \multirow[b]{2}{*}{ Область } & \multicolumn{8}{|c|}{ Роки, \% } & \multirow{2}{*}{\begin{tabular}{|c|} 
Зміни \\
2014-2010 pp., \\
$\%$ \\
\end{tabular}} & \multirow{2}{*}{\begin{tabular}{|c|} 
Зміни \\
$2017-2014$ pp., \\
$\%$
\end{tabular}} \\
\hline & 2010 & 2011 & 2012 & 2013 & 2014 & 2015 & 2016 & 2017 & & \\
\hline Київська & 23,5 & 30,1 & 22,9 & 20,8 & 11,0 & 15,7 & 9,1 & 39,3 & 15,8 & 18,5 \\
\hline Вінницька & 4,4 & 6,0 & 9,0 & 3,4 & 10,5 & 7,3 & 7,0 & 12,5 & 8,1 & 9,1 \\
\hline Черкаська & 4,5 & 0,7 & 1,5 & 1,7 & 3,2 & 1,3 & 6,3 & 11,5 & 7,0 & 9,8 \\
\hline Кіровоградська & 5,8 & 8,4 & 6,1 & 6,5 & 5,0 & 5,8 & 5,3 & 10,5 & 4,6 & 3,9 \\
\hline Волинська & 8,7 & 2,3 & 3,3 & 2,1 & 1,5 & 2,9 & 41,9 & 4,9 & $-3,8$ & 2,8 \\
\hline Миколаївська & 3,1 & 12,3 & 15,8 & 30,7 & 16,9 & 28,5 & 6,8 & 2,9 & $-0,2$ & $-27,8$ \\
\hline Одеська & 7,7 & 8,1 & 19,9 & 11,0 & 20,9 & 10,6 & 29,2 & 2,5 & $-5,2$ & $-8,5$ \\
\hline Закарпатська & 15,1 & 18,3 & 26,9 & 26,7 & 19,1 & 12,6 & 3,1 & 1,8 & $-13,3$ & $-24,8$ \\
\hline Харківська & 1,6 & 22,1 & 2,6 & 3,9 & 2,0 & 0,9 & 1,0 & 1,4 & $-0,1$ & $-2,5$ \\
\hline Чернігівська & 11,0 & 12,4 & 9,3 & 9,4 & 13,6 & 11,2 & 18,5 & 19,5 & 8,5 & 10,1 \\
\hline Хмельницька & 10,5 & 11,6 & 11,6 & 9,3 & 12,6 & 11,2 & 19,6 & 18,1 & 7,5 & 8,8 \\
\hline Львівська & 23,8 & 25,9 & 25,1 & 23,9 & 27,8 & 23,7 & 49,0 & 57,1 & 33,2 & 33,2 \\
\hline
\end{tabular}

Ажерело: побудовано автором на основі аналізу даних $[2 ; 8]$. 
ЕКОНОМІЧНА НАУКА

Таблиця 6. Рентабельність активів промислових організацій по областях України за період 2010-2017 рр.

\begin{tabular}{|c|c|c|c|c|c|c|c|c|c|c|}
\hline \multirow[b]{2}{*}{ Область } & \multicolumn{8}{|c|}{ Роки, \% } & \multirow{2}{*}{$\begin{array}{c}\text { Зміни } \\
2014-2010 \text { pp., } \\
\text { млн грн }\end{array}$} & \multirow{2}{*}{\begin{tabular}{|c|} 
Зміни \\
$2017-2014$ pp., \\
млн грн
\end{tabular}} \\
\hline & 2010 & 2011 & 2012 & 2013 & 2014 & 2015 & 2016 & 2017 & & \\
\hline Київська & 7,4 & 9,0 & 10,0 & 4,9 & 9,1 & 11,5 & 14,1 & 10,6 & 3,2 & 5,7 \\
\hline Вінницька & 11,5 & 14,5 & 16,8 & 12,7 & 10,1 & 12,5 & 13,7 & 8,5 & $-3,0$ & $-4,3$ \\
\hline Черкаська & 22,8 & 10,2 & 9,5 & 15,0 & $-3,0$ & 14,5 & 10,1 & 7,2 & $-15,6$ & $-7,9$ \\
\hline Кіровоградська & 3,1 & $-0,7$ & 8,6 & 6,3 & 1,6 & 3,7 & 2,9 & 5,5 & 2,4 & $-0,9$ \\
\hline Волинська & 9,7 & 3,4 & 7,7 & 9,1 & 1,5 & $-0,9$ & 0,1 & 5,4 & $-4,3$ & $-3,7$ \\
\hline Миколаївська & 11,0 & 6,5 & 5,2 & 3,3 & 4,9 & 8,7 & 7,8 & 3,9 & $-7,1$ & 0,6 \\
\hline Одеська & 0,4 & 0,6 & $-1,4$ & $-0,1$ & $-0,5$ & 2,1 & 0,1 & $-0,3$ & $-0,7$ & $-0,2$ \\
\hline Закарпатська & 29,5 & 9,4 & 18,6 & 7,6 & 1,8 & 1,5 & 2,5 & $-0,6$ & $-30,0$ & $-8,2$ \\
\hline Харківська & 3,2 & $-4,7$ & $-0,4$ & $-2,8$ & 2,4 & 3,0 & $-2,4$ & $-3,9$ & $-7,1$ & $-1,1$ \\
\hline Чернігівська & 9,2 & 11,3 & 9,9 & 7,1 & 5,7 & 8,1 & 7,9 & 7,0 & $-2,2$ & $-0,2$ \\
\hline Хмельницька & 8,8 & 9,1 & 8,6 & 5,6 & 6,3 & 8,8 & 8,7 & 6,2 & $-2,6$ & 0,6 \\
\hline Львівська & 15,7 & 16,7 & 13,9 & 14,8 & 8,3 & 13,2 & 10,6 & 3,0 & $-12,7$ & $-11,8$ \\
\hline
\end{tabular}

Ажерело: побудовано автором на основі аналізу даних [2; 8].

мисловість області, за останній період склала всього лише $2,5 \%$ (табл. 5 ).

Частина витрат, що спрямовуються на технологічні інновації, відображається і в низькій чисельності працівників, які виконують наукові дослідження та розробки, що в свою чергу впливає на ефективність їх впровадження. У 2017 р. даний показник в розрахунку на тисячу зайнятих по Україні становить 55 осіб, по областях - 73 людини. У Київській області число зайнятих складає 36 осіб на тисячу зайнятих в промисловості, в Вінницькій - 28, а у Черкаській області спостерігається найнижче значення даного показника - усього 3 людини, причому за досліджуваний період, скорочення склало 8,6\% (з 464 до 424 осіб) [8]. Кількість організацій, що виконували наукові дослідження і розробки серед промислових виробництв по Черкаській області склало всього дві одиниці, а кількість створених ними інноваційних виробничих технологій — одна [8].

Низькі значення показника рентабельності активів по Україні та областях є однією з головних причин негативних фінансових результатів промислових організацій. Найбільша рентабельність активів організацій промисловості спостерігається у Київській, Вінницькій та Черкаській областях $(10,6,8,5 \%$ і 7,2 відповідно). Серед областей України слід виділити Одеську, Закарпатську, Харківську області, в яких вкладення в майно промислових організацій не приносить відповідної віддачі, рентабельність активів має негативні значення $(-0,3,-0,6,-3,9$ відповідно). Ааний показник по Черкаській області в 2017 р. і так низький - всього лише $5,4 \%$, крім того, за аналізований період ще й знизився на $4,3 \%$ (табл. 6$)$.

У період з 2010-2017 рр. по областях України простежується тенденція до зменшення кваліфікованого виробничо-промислового персоналу в загальній кількості зайнятих в економіці країни. Кіровоградська і Волинська області є єдиними суб'єктами, де за дослід-

Таблиця 7. Питома вага виробничо-промислового персоналу в загальній кількості зайнятих в економіці по областях за період 2010-2017 рр.

\begin{tabular}{|c|c|c|c|c|c|c|c|c|c|c|}
\hline \multirow[b]{2}{*}{ Область } & \multicolumn{8}{|c|}{ Роки, \% } & \multirow{2}{*}{$\begin{array}{c}\text { Зміни } \\
2014-2010 \text { pp., } \\
\%\end{array}$} & \multirow{2}{*}{$\begin{array}{c}\text { 3міни } \\
2017-2014 \text { pp., } \\
\%\end{array}$} \\
\hline & 2010 & 2011 & 2012 & 2013 & 2014 & 2015 & 2016 & 2017 & & \\
\hline Київська & 27,14 & 26,73 & 26,75 & 26,72 & 26,49 & 26,67 & 26,24 & 26,44 & $-0,70$ & $-0,27$ \\
\hline Вінницька & 25,54 & 25,34 & 25,16 & 25,05 & 24,25 & 24,76 & 24,64 & 24,15 & $-1,39$ & $-0,91$ \\
\hline Черкаська & 27,13 & 26,29 & 26,06 & 25,11 & 23,90 & 24,54 & 24,44 & 23,65 & $-3,48$ & $-1,46$ \\
\hline Кіровоградська & 22,43 & 21,49 & 21,31 & 21,39 & 21,31 & 22,79 & 22,79 & 23,00 & 0,58 & 1,61 \\
\hline Волинська & 18,69 & 23,36 & 22,91 & 22,89 & 21,88 & 21,60 & 21,48 & 21,56 & 2,88 & $-1,32$ \\
\hline Миколаївська & 21,69 & 21,67 & 20,88 & 20,23 & 19,87 & 20,29 & 20,52 & 20,21 & $-1,48$ & $-0,02$ \\
\hline Одеська & 20,29 & 20,64 & 20,93 & 20,78 & 19,97 & 19,95 & 19,53 & 19,73 & $-0,56$ & $-1,04$ \\
\hline Закарпатська & 20,80 & 20,70 & 20,58 & 20,07 & 19,44 & 20,36 & 20,02 & 19,31 & $-1,50$ & $-0,76$ \\
\hline Харківська & 21,23 & 20,03 & 19,85 & 19,60 & 18,40 & 18,30 & 17,91 & 18,00 & $-3,23$ & $-1,67$ \\
\hline Чернігівська & 21,66 & 21,33 & 21,05 & 20,62 & 19,69 & 19,67 & 19,63 & 19,42 & $-2,25$ & $-1,20$ \\
\hline Хмельницька & 21,87 & 21,70 & 21,23 & 20,74 & 19,78 & 20,05 & 19,95 & 19,87 & $-2,00$ & $-0,87$ \\
\hline Львівська & 19,75 & 19,32 & 18,21 & 17,38 & 15,94 & 15,87 & 15,91 & 16,15 & $-3,61$ & $-1,23$ \\
\hline
\end{tabular}

Ажерело: побудовано автором на основі аналізу даних [2; 8]. жуваний період простежується приріст даного показника $(+0,58 \%$ i $+2,88 \%)$. У Черкаській області спостерігається найбільше зниження даного показника $(-3,48 \%)$ серед областей (у 2017 р. - 23,65\% проти 27,13\% в 2010 р., табл. 7).

Вагоме значення для промислового потенціалу має розвинена транспортна інфраструктура. В Україні щільність залізничних колій у 2017 р. становить 38 км на тисячу кв. метрів території, а автомобільних - 44 км. За досліджуваний період у розвитку транспортної інфраструктури Черкаської області практично якісні зміни відсутні. Як у 2010 р., так і 2017 р. область значно відстає за густотою залізничних і автомобільних доріг, наприклад, у порівнянні з Закарпатською областю (лідер по щільності залізничних і автомобільних доріг).

Загалом, для досягнення промислового і загального економічного зростання території Черкаської області необхідно більшу увагу приділяти розвитку дорожньої мережі, транспортних розв'язок та підтримці існуючих автомобільних доріг відповідно норм АСТУ, а також залізничних мереж території. Розвиток інфраструктури сприяє більш якісному та ефективному управлінню матеріальними потоками в процесі закупівлі, постачання, перевезення і зберігання матеріалів, деталей і готової продукції, оптимізує витрати і раціоналізує процес виробництва, реалізацію і супутній сервіс як в межах одного підприємства, так і всієї промисловості регіону.

Аналізуючи інвестиційний потенціал промисловості України, необхідно звернути увагу на скорочення частки банківського капіталу, який направлено в розвиток промислового сектора України та областей. 3 20132017 рр. частка банківських інвестицій в загальному обсязі інвестицій в Кіровоградській області скоротилася на 7,4\%, в Черкаській - на 6,1\%, Харківській - на $10 \%$. Частка банківських інвестицій Одеській області за досліджуваний проміжок часу зменшилася на 3,9\%, склавши в 2017 р. всього 3,9\% від загального обсягу інвестицій в промисловості. $\Lambda$ ідером серед областей за цим показником є Київська область, де частка банківського капіталу склала $19,7 \%$ (табл. 8).

Також, має місце зниження частки інвестицій, що спрямовуються в машини, обладнання та транспортні засоби промислових підприємств. Найбільше зниження даного показника спостерігається в Миколаївській області - на $28 \%$, Волинській області - на 19,9\%, Закарпатській області - на 16,2\%. За досліджуваний період частка даного показника в Черкаській області скоротилася на 7,6\% і за підсумками 2017 р. склала 28,2\% (табл. 9).

У ході проведеного дослідження було розраховано значення інтегрального показника промислового потенціалу областей.Аля його обчислення, а також для визначення відмінностей показників за регіонами було застосовано метод багатовимірного порівняльного аналізу, який дає змогу враховувати не тільки абсолютні величини показників кожного регіону, а й ступінь їх розміщення до показника-еталону. У зв'язку з цим координати порівнюваних областей відображаються у відсотках відповідних координат еталона. За еталонні показники узято макси- 
мальне або мінімальне значення індивідуального показника в обраних областях за весь період дослідження. Результати розрахунку інтегрального показника промислового потенціалу областей України подано в таблиці 10.

Аналізуючи дані таблиці 10 за 2010-2017 рр. значення інтегральних показників промислового потенціалу областей України малинезначні коливання. У 2017 р. до групи і "середнім" рівнем потенціалу увійшли більшість областей. Найвищі значення інтегрального показника промислового потенціалу спостерігається у Київській та Вінницькій областях. Найнижчі - у Харківській та Чернігівській областях. Істотно наростити свій потенціал змогли Київська та Закарпатська області $(+0,146$ i $+0,117$ відповідно), що відзначається переходом даних суб'єктів 3 групи 3 рівнем потенціалу "нижче середнього" в групу з "середнім" рівнем. У Черкаській, Волинській, Миколаївській областях за досліджуваний період спостерігається зниження значення інтегрального показника промислового потенціалу.

Значення інтегрального індексу промислового потенціалу Черкаської області в 2017 р. становить 0,39 . Варто відзначити значне зниження індексу в 2013-2014 рр., що пов'язано з реакцією на несприятливу економіко-політичну ситуацію в країні. Слід зауважити, що визначення впливу окремих потенціалів на інтегральний показник промислового потенціалу Черкаської області супроводжується різким зниженням фінансових можливостей розвитку, вкрай низькими показниками інноваційного, інфраструктурного та інвестиційного потенціалів. Порівняльна оцінка промислового потенціалу показала, що погіршення позицій Черкаської області обумовлене низьким технічним станом основних виробничих фондів, які за ступенем зносу по окремих галузях перевищують критичний рівень, а також незначною кількістю організацій, що виконують наукові дослідження, низькою чисельністю висококваліфікованих робітничих кадрів, негативними фінансовими результатами деяких промислових підприємств.
Таблиця 8. Банківські інвестиції в загальному обсязі інвестицій в промисловість 3а 2010-2017 pp.

\begin{tabular}{|c|c|c|c|c|c|c|c|c|c|c|}
\hline \multirow{2}{*}{ Область } & \multicolumn{8}{|c|}{ Роки, \% } & \multirow{2}{*}{$\begin{array}{c}\text { Зміни } \\
2014-2010 \text { pp., } \\
\%\end{array}$} & \multirow{2}{*}{\begin{tabular}{|c|} 
Зміни \\
2017-2014 pp., \\
$\%$
\end{tabular}} \\
\hline & 2010 & 2011 & 2012 & 2013 & 2014 & 2015 & 2016 & 2017 & & \\
\hline Київська & 30 & 12,5 & 27,1 & 24 & 7,7 & 5,3 & 11,4 & 19,7 & $-10,3$ & $-4,3$ \\
\hline Вінницька & 20,3 & 8,7 & 13,9 & 21,1 & 12,6 & 11 & 14,5 & 17,4 & $-2,9$ & $-3,7$ \\
\hline Черкаська & 2,2 & 10,1 & 17,8 & 17,7 & 3,1 & 19,5 & 6,9 & 11,6 & 9,4 & $-6,1$ \\
\hline Кіровоградська & 3,2 & 10,3 & 7,6 & 14,9 & 13,8 & 14,5 & 15,2 & 7,5 & 4,3 & $-7,4$ \\
\hline Волинська & 4,2 & 6,9 & 6,7 & 6,9 & 7,8 & 4,5 & 13,5 & 4,3 & 0,1 & $-2,6$ \\
\hline Миколаївська & 4,2 & 2,3 & 4,3 & 6,5 & 5,4 & 3,3 & 3,5 & 4,1 & $-0,1$ & $-2,4$ \\
\hline Одеська & 7,5 & 3,7 & 11,4 & 7,2 & 10,8 & 9,2 & 4,9 & 3,6 & $-3,9$ & $-3,6$ \\
\hline Закарпатська & 6,5 & 4,6 & 11,3 & 3,7 & 7,3 & 9,3 & 2,4 & 1,0 & $-5,5$ & $-2,7$ \\
\hline Харківська & 2,1 & 1,7 & 9,3 & 10,4 & 8,7 & 15,7 & 1,1 & 0,4 & $-1,7$ & -10 \\
\hline Чернігівська & 8,1 & 9,6 & 10,4 & 11,8 & 9 & 10,3 & 19,2 & 8,4 & 0,3 & $-3,4$ \\
\hline Хмельницька & 8,6 & 7,8 & 9,4 & 10,6 & 11,3 & 9,2 & 8,9 & 6 & $-2,6$ & $-4,6$ \\
\hline Львівська & 11,6 & 14,7 & 9,6 & 12,3 & 17,3 & 10,7 & 13,8 & 11,1 & $-0,5$ & $-1,2$ \\
\hline
\end{tabular}

Ажерело: побудовано автором на основі аналізу даних $[2 ; 8]$.

Таблиця 9. Інвестиції в машини, обладнання та транспортні засоби від загального обсягу інвестицій в основний капітал промислових підприємств 3а 2010-2017 pp.

\begin{tabular}{|c|c|c|c|c|c|c|c|c|c|c|}
\hline \multirow{2}{*}{ Область } & \multicolumn{8}{|c|}{ Роки, \% } & \multirow{2}{*}{$\begin{array}{c}\text { Зміни } \\
2014-2010 \text { pp., } \\
\%\end{array}$} & \multirow{2}{*}{\begin{tabular}{|c|} 
3міни \\
$2017-2014$ pp., \\
$\%$ \\
\end{tabular}} \\
\hline & 2010 & 2011 & 2012 & 2013 & 2014 & 2015 & 2016 & 2017 & & \\
\hline Київська & 71,0 & 68,9 & 63,3 & 70,9 & 64,0 & 48,3 & 60,6 & 56,6 & $-14,4$ & $-14,3$ \\
\hline Вінницька & 53,9 & 58,3 & 49,2 & 46,2 & 51,1 & 43,5 & 50,7 & 52,2 & $-1,7$ & 6,0 \\
\hline Черкаська & 55,1 & 46,3 & 53,4 & 53,5 & 43,0 & 40,9 & 41,7 & 38,9 & $-16,2$ & $-14,6$ \\
\hline Кіровоградська & 30,0 & 24,1 & 25,9 & 26,9 & 31,0 & 30,9 & 36,9 & 34,0 & 4,0 & 7,1 \\
\hline Волинська & 52,2 & 57,8 & 43,9 & 33,2 & 37,9 & 29,5 & 40,2 & 32,3 & $-19,9$ & $-0,9$ \\
\hline Миколаївська & 56,5 & 51,3 & 47 & 40,7 & 45,4 & 44,2 & 33,3 & 28,5 & $-28,0$ & $-12,2$ \\
\hline Закарпатська & 35,8 & 30,4 & 35,1 & 36,4 & 45,9 & 46,2 & 35,2 & 28,2 & $-7,6$ & $-8,2$ \\
\hline Одеська & 41,2 & 28,9 & 32,5 & 28,3 & 31,5 & 30,1 & 36,2 & 28,3 & $-12,9$ & 0 \\
\hline Харківська & 39,5 & 29,5 & 39,3 & 32,3 & 26,0 & 21,6 & 33,6 & 26,8 & $-12,7$ & $-5,5$ \\
\hline Чернігівська & 41,1 & 37,7 & 38,9 & 35,4 & 37,2 & 38,6 & 37,9 & 36,3 & $-4,8$ & 0,9 \\
\hline Хмельницька & 44,0 & 37,5 & 39,3 & 37,5 & 38,3 & 36,7 & 39,9 & 35,3 & $-8,7$ & $-2,2$ \\
\hline Львівська & 46,4 & 44,7 & 44,0 & 41,0 & 41,3 & 43,3 & 46,2 & 47,8 & 1,4 & 6,8 \\
\hline
\end{tabular}

Ажерело: побудовано автором на основі аналізу даних [2; 8].

На основі проведеного аналізу процесів формування і розподілу інвестиційних ресурсів в промисловість регіону встановлено, що за період 3 2010-2017 рр. найбільше інвестицій надходило лише в хімічні і металургійні виробництва [2; 8]. Така тенденція обмежує можливості досягнення стабільного і збалансованого економічного зростання промислового сектору, сприяє збереженню сировинної спрямованості промислового розвитку, перешкоджає активізації процесів диверсифікації. Також, слід зазначити, що розвиток промислового потенціалу Черкаської області порівняно з іншими областями України був повільнішим: про це свідчить переміщення суб'єкта в рейтингу з 4-го на 7-е місце, а також ряд показників потенціалу (табл. 11).

Таблиця 10. Інтегральні показники промислового потенціалу України*, *

\begin{tabular}{|c|c|c|c|c|c|c|c|c|c|c|c|}
\hline \multirow[b]{2}{*}{ Область } & \multicolumn{8}{|c|}{ Роки } & \multirow{2}{*}{\begin{tabular}{|c|} 
Зміни \\
$2014-$ \\
2010 рр. \\
\%
\end{tabular}} & \multirow{2}{*}{$\begin{array}{c}\text { Зміни } \\
2017- \\
2014 \text { pp., } \\
\%\end{array}$} & \multirow{2}{*}{$\begin{array}{l}\text { Загальна } \\
\text { динаміка } \\
32010 \text { p. }\end{array}$} \\
\hline & 2010 & 2011 & 2012 & 2013 & 2014 & 2015 & 2016 & 2017 & & & \\
\hline Київська & 0,378 & 0,393 & 0,419 & 0,422 & 0,437 & 0,452 & 0,547 & 0,524 & $+0,087$ & $+0,146$ & $\Delta$ \\
\hline Вінницька & 0,540 & 0,510 & 0,545 & 0,518 & 0,489 & 0,488 & 0,508 & 0,509 & $+0,020$ & $-0,030$ & $\nabla$ \\
\hline Черкаська & 0,419 & 0,400 & 0,432 & 0,469 & 0,374 & 0,343 & 0,384 & 0,390 & $+0,015$ & $-0,030$ & $\nabla$ \\
\hline Кіровоградська & 0,412 & 0,425 & 0,443 & 0,426 & 0,433 & 0,433 & 0,417 & 0,435 & $+0,002$ & $+0,023$ & $\boldsymbol{\Delta}$ \\
\hline Волинська & 0,432 & 0,387 & 0,411 & 0,430 & 0,356 & 0,409 & 0,427 & 0,423 & $+0,068$ & $-0,009$ & $v$ \\
\hline Миколаївська & 0,469 & 0,445 & 0,476 & 0,448 & 0,432 & 0,412 & 0,416 & 0,417 & $-0,015$ & $-0,051$ & $\nabla$ \\
\hline Закарпатська & 0,330 & 0,356 & 0,405 & 0,391 & 0,413 & 0,428 & 0,436 & 0,447 & $+0,034$ & $+0,117$ & $\mathbf{\Delta}$ \\
\hline Одеська & 0,319 & 0,339 & 0,351 & 0,355 & 0,342 & 0,380 & 0,35 & 0,383 & $+0,041$ & $+0,064$ & $\Delta$ \\
\hline Харківська & 0,340 & 0,377 & 0,412 & 0,409 & 0,374 & 0,366 & 0,352 & 0,375 & $+0,001$ & $+0,035$ & $\boldsymbol{\Delta}$ \\
\hline Чернігівська & 0,31 & 0,37 & 0,38 & 0,41 & 0,39 & 0,36 & 0,39 & 0,37 & $+0,002$ & $+0,015$ & $\Delta$ \\
\hline Хмельницька & 0,34 & 0,37 & 0,39 & 0,42 & 0,41 & 0,37 & 0,39 & 0,41 & $+0,001$ & $+0,017$ & $\boldsymbol{\Delta}$ \\
\hline Львівська & 0,36 & 0,44 & 0,40 & 0,42 & 0,39 & 0,38 & 0,32 & 0,38 & $+0,026$ & $+0,036$ & $\Delta$ \\
\hline
\end{tabular}

* Ранжування областей за рівнем 2017 року.

$\square-$ середнє значення показника, $\square-$ значення показника нижче середнього;

$\boldsymbol{\Delta}$ - збільшення показника промислового потенціалу; $\boldsymbol{\nabla}$ - показники промислового потенціалу з $2010 \mathrm{p}$.

*^Ажерело: побудовано автором на основі проведеного дослідження. 
Таблиця 11. Рейтинг рівня промислового потенціалу деяких областей України

\begin{tabular}{|l|l|l|l|l|l|l|l|l|}
\hline \multirow{2}{*}{ Область } & \multicolumn{9}{|c|}{ Роки } \\
\cline { 2 - 10 } & 2010 & 2011 & 2012 & 2013 & 2014 & 2015 & 2016 & 2017 \\
\hline Київська & 6 & 5 & 5 & 6 & 2 & 2 & 1 & 1 \\
\hline Вінницька & 1 & 1 & 1 & 1 & 1 & 1 & 2 & 2 \\
\hline Черкаська & 4 & 4 & 4 & 2 & 7 & 9 & 7 & 7 \\
\hline Кіровоградська & 5 & 3 & 3 & 5 & 3 & 3 & 5 & 4 \\
\hline Волинська & 3 & 6 & 7 & 4 & 8 & 6 & 4 & 5 \\
\hline Миколаївська & 2 & 2 & 2 & 3 & 4 & 5 & 6 & 6 \\
\hline Закарпатська & 8 & 8 & 8 & 8 & 5 & 4 & 3 & 3 \\
\hline Одеська & 9 & 9 & 9 & 9 & 9 & 7 & 8 & 8 \\
\hline Харківська & 7 & 7 & 6 & 7 & 6 & 8 & 9 & 9 \\
\hline Чернігівська & 5 & 3 & 3 & 5 & 3 & 3 & 5 & 4 \\
\hline Хмельницька & 3 & 6 & 7 & 4 & 8 & 6 & 4 & 5 \\
\hline Львівська & 3 & 2 & 3 & 3 & 4 & 5 & 4 & 4 \\
\hline
\end{tabular}

Ажерело: побудовано автором на основі проведеного дослідження.
4. Каплан Р.С. Сбалансированная система показателей. От стратегии к действию/ Р.С. Каплан, А.П. Нортон. - М.: Олимп-Бизнес, 2006. $304 \mathrm{c}$.

5. Никитаева А.Ю. Институциональная структура региона в контексте инновационного развития промышленности / / Journal of Institutional Studies. - 2017. — № 1. - C. 134149.

6. Свинцова А.П. Промышленный потенциал: понятие, критерии, структура [Электронный ресурс]/ А.П. Свинцова // Экономический вестник УГНТУ. - 2017. - Режим доступа : http:// www.masters.donntu. edu.ua/2012/igg/kameristaya/library/article1.htm

7. Статистична інформація про виробництво

Аані таблиці 11 вказують на те, що перші місця в рейтингу областей у 2017 р. займають Київська і Вінницька області. Загалом вивчення індексів за блоками показників дало змогу зробити висновок, про те що Черкаська область не змогла продемонструвати рівномірного розвитку за усіма складовими промислового потенціалу. 3 одного боку, це вказує на наявність проблемних зон і резервів зростання промислового потенціалу, а 3 іншого - показує яким чином можна розвивати промисловий потенціал регіону покращуючи його окремі складові.

\section{ВИСНОВКИ}

Зважаючи на результати поведеного регіонального дослідження щодо формування промислового потенціалу, слід сказати, що промисловий потенціал регіонів України використовується не повною мірою. Розвитку промисловості регіону перешкоджають низькі показники розвитку матеріально-технічної, інноваційної, інвестиційної, трудовӧ̈, інфраструктурної, фінансової складових, що визначають його промисловий потенціas.

Аля усунення проблем, що гальмують розвиток промислового потенціалу регіону, необхідним є формування промислової політики, яка б відповідала сучасним економічним умовам, i була спрямована, перш за все, на підвищення техніко-технологічного рівня виробничої діяльності промислових підприємств.

Разом $з$ тим політика, що проводиться регіональними органами влади, також повинна враховувати необхідність активізації процесів диверсифікації в промисловому секторі економіки, оскільки вони регулюють процеси розвитку структурних елементів промислового потенціалу за допомогою інститутів та інструментів Аиверсифікації. А комплексне використання таких інструментів промислової політики, як експортоорієнтованість та імпортозаміщення, дадуть імпульс цілеспрямованому розвитку стратегічно важливих галузей промисловості, інноваційно-інвестиційної активності бізнесу, а також стимулюватимуть залучення іноземних інвестицій та активізацію вітчизняних. Також слід звернути увагу на досвід економічно розвинених країн у напрямі використання основ диверсифікації щодо розвитку промислово розвинених регіонів.

\section{$\Lambda$ ітература:}

1.Аацій О.І. Оцінка рівня реалізації власного потенціалу регіону // Науковий вісник Академії муніципального управління. Серія "Управління". Випуск 2. -2013. - C. 336-345.

2. Аержавна служба статистики України [Електронний ресурс]. - Режим доступу: http://www.ukrstat.gov.ua

3.Аикий О.В. Основні пріоритети та механізм стратегічного планування соціально-економічного розвитку регіонів/ О.В.Аикий// Ефективна економіка. - 2011. - [Електронний ресурс]: Режим доступу: http:/ www.economy.nayka.com.ua/index.php?operation $=1 \&$ iid $=803$ основних видів промислової продукції [Електронний ресурс]// Офіційний сайт Аержавної служби статистики України. - Режим доступу: http:// www.ukrstat.gov.ua

8. Україна у цифрах у 2009-2017 рр.// [стат. зб.; за К.: Аержавна служба статистики України, 2017. - 539 с.

9. Bianchi P. and Labory S. The institutional framework of Industrial policies. Quaderno DEM, vol. 3, 20/2014, pp. $15-23$.

10. Berry C. Industrial policy change in the post-crisis British economy: Policy innovation in an incomplete institutional and ideational environment. The British Journal of Politics and International Relations. vol. 18, Issue 4/2016, pp. $829-847$.

References:

1. Datsij, O.I. (2013), "Assessing the level of implementation of the region's potential", Naukovyj visnyk Akademii munitsypal'noho upravlinnia. seriia "Upravlinnia", vol. 2, pp. 336-345.

2. The State Statistics Service of Ukraine (2018), Available at: http://www.ukrstat.gov.ua (Accessed 01 November 2018).

3. Dykyi, O.V. (2011), "Main priorities and mechanism of strategic planning of socio-economic development of regions", Efficient economy, Available at: http:// ww w. economy.nayka.com.ua/index.php?operation $=1 \&$ iid $=803$

4. Kaplan, R. and Norton, D. (2006). Sbalansirovannaya sistema pokazateley. Ot strategii k deystviyu [Balanced scorecard. From strategy to action], Olimp-Biznes, Moscow, Russia.

5. Nikitaeva, A.Yu. (2017), "Institutional structure of the region in the context of innovation development of industry", Journal of Institutional Studies, vol. 9 (1), pp. $134-149$

6. Svintsova, A.P. (2012), "Industrial Potential: Concept, Criteria, Structure", Ekonomicheskii vestnik UGNTU, available at: http://www. masters.donntu.edu.ua/2012/igg/ kameristaya/library/article1.htm (Accessed 01 November 2018).

7. State Statistics Service of Ukraine (2018), "Statistical information on the production of basic types of industrial products", available at: http://www.ukrstat.gov.ua/ (Accessed 01 November 2018).

8. Zhuk, I.M. (2017), Ukraina u tsyfrakh u 2009-2017 rr. [Ukraine in figures in 2009-2017], Derzhavna sluzhba statystyky Ukrainy, Kyiv, Ukraine.

9. Bianchi, P. and Labory, S. (2014), "The institutional framework of Industrial policies", Quaderno DEM., vol. 3 (20), pp.15-23.

10. Berry, C. (2016), "Industrial policy change in the post-crisis British economy: Policy innovation in an British Journal of Politics and International Relations, vol. 18 (4), pp. 829-847.

Стаття надійила до редакцї 07.11.2018 p. ред. I.M. Жук] Аержавна служба статистики України. incomplete institutional and ideational environment", The 
$\mathrm{Y} \triangle \mathrm{K} 339$

О.Г. Мельник,

д.е.н., професор, завідувач кафедри зовнішньоекономічноӥ та митної ділльності,

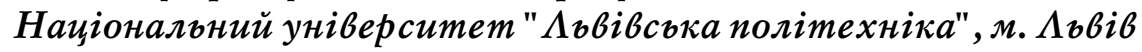

M.E. Aдамів,

к.е.н., дочент кафедри зовнішньоекономічної та митної діяльності,

Начіональний університет " $ь$ вівсъка політехніка", м. Аъвів

A. В. Тодощук,

к.е.н., дочент кафедри зовнішньоекономічної та митної діяльності,

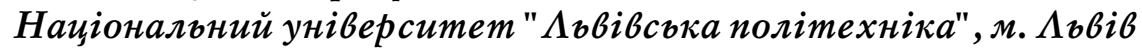

DOI: $10.32702 / 2306-6806.2018 .11 .39$

\title{
КОНЦЕПТУААЬНІ ЗАСААИ РЕФОРМУВАННЯ МИТНОЇ СИСТЕМИ УКРАЇНИ В УМОВАХ ЄВРОПЕЙСЬКОЇ ІНТЕГРАЦІї ${ }^{1}$
}

\author{
O. Melnyk, \\ Doctor of Economic Sciences, Professor, Head of Department of Foreign Economic \\ and Customs Activity, Lviv Polytechnic National University, Lviv \\ M. Adamiv, \\ Doctor of Philosophy in Economics, Associate Professor of Department of Foreign \\ Economic and Customs Activity, Lviv Polytechnic National University, Lviv \\ A. Todoshchuk, \\ Doctor of Philosophy in Economics, Associate Professor of Department of Foreign \\ Economic and Customs Activity, Lviv Polytechnic National University, Lviv
}

\section{CONCEPTUAL PRINCIPLES OF REFORMING THE CUSTOMS SYSTEM OF UKRAINE IN TERMS OF EUROPEAN INTEGRATION}

У статті доведено необхідність застосування наукового підходу до реформування митної системи України в умовах європейської інтеграції. На підставі врахування існуючих проблем у вітчизняному досвіді модернізації роботи митних органів та аналізування кАасичних і сучасних наукових теорій рекомендовано використовувати системний підхі, до реформування митної сфери. Запропоновано розгляАати національнУ митну систему як скАаднуцілісну контрольовану структуру, що відображає сукупність базових та забезпечувальних підсистем з притаманними їм елементами, які розвиваються під впливом внутрішніх та зовнішніх чинників та у взаємодії забезпечують виконання іманентних митних функцій. Виконано структурну декомпозицію митної системи за топологічно-змістовою ознакою, що дало змогу виокремити базові підсистеми (контрольно-регулююча, безпеково-захисна, сервісна, фіскальна підсистеми) та забезпечувальні підсистеми (нормативно-правова, адміністративна, фінансова, інформаційноСтатистична, комунікаційна, матеріадьно-технічна підсистеми, підсистема міжнародного співробітництва). Розкрито змістове наповнення та функціональне призначення кожної структурної підсистеми національної митної системи, що сформувало систематизовану інформаційну базу Аля подальшого реформування вітчизняної митної сфери.

The current stage of functioning of the national customs system reflects the existence of significant problems in its various spheres. In spite of numerous attempts to modernize the work of customs authorities by representatives of different levels, unfortunately the visible result has not been achieved. The problem of reforming the national customs system became especially critical in the context of European integration. It is grounded by the obligations of Ukraine to harmonize the customs sphere with European standards and norms according to the Association Agreement with the European Union. On the basis of unsuccessful attempts to improve the work of customs authorities, it has been proved that the reform process should be scientifically grounded. The application of a scientific approach will ensure a coherent, completed, integrated and structured vision of the

${ }^{1}$ Публікація містить результати досліджень, проведених при грантовій підтримці Аержаного фонду фундаментальних досліджень за конкурсним проектом Ф83/81-2018. 
reform process, identify and justify the priority areas of modernization, and will allow achieving the most effective results. Based on the study of existing problems in the domestic experience of modernizing the work of customs authorities, analyzing classical and modern scientific theories, taking into account tendencies of European integration, it is recommended to use a systematic approach to the reform of the customs sphere. It is proposed to consider the national customs system as a complex integral controlled structure, which reflects a set of basic and supporting subsystems with their inherent elements, which develop under the influence of internal and external factors and in interaction ensure the implementation of immanent customs functions. In order to reveal the content and functional purpose of the subsystems of the national customs system, its structural decomposition was made by the topological and content signs, which forms a systematic information base for further reformation of the domestic customs sphere. In particular, the basic subsystems (control-regulating, security-protective, service, fiscal subsystems) and supporting subsystems (normative-legal, administrative, financial, informationalstatistical, communication, material-technical subsystems, subsystem of international cooperation) are identified.

Ключові слова: митна система, структурна декомпозичія, базові підсистеми, забезпечувальні підсистеми, реформування, європейсвка інтеграчія.

Key words: customs system, structural decomposition, basic subsystems, supporting subsystems, reformation, European integration.

\section{ПОСТАНОВКА ПРОБЛЕМИ}

Після вибору євроінтеграційного вектору розвитку та ратифікації Угоди про асоціацію із Европейським Союзом перед Україною постало чимало зобов'язань щодо приведення ключових сфер держави у відповідність із європейськими стандартами та нормами. Одним із невід'ємних компонентів гармонізаційного процесу є митна система України, що покликана забезпечувати реалізацію найбільш істотних функцій держави. В умовах поширення інтеграційних та глобалізаційних тенденцій світового розвитку виникає необхідність в уніфікації національних митних систем, що об'єднуватимуться спільною ідеєю функціонування, орієнтуватимуться на однакові принципи та стандарти діяльності, використовуватимуть єдині підходи та методи роботи. Така уніфікація в жодному випадку не нівелюватиме національні митні інтереси, а, навпаки, сприятиме вирішенню існуючих внутрішніх проблем і забезпеченню прогресивного розвитку митної сфери та держави загалом.

У будь-якій країні світу митна система окреслює $1 і ̈$ державні кордони, утворюючи тим самим територіальну цілісність; є своєрідним бар'єром для переміщення небезпечної продукції через кордон, формуючи таким чином національну безпеку; виконує роль лакмусового індикатора для перевірки якості товарів, здійснюючи захист суспільства від шкідливої та неякісної продукції; сприяє веденню законної міжнародної торгівлі підприємствами, спрощуючи митні процедури перетину кордону; активізує зовнішньоекономічну діяльність суб'єктів господа рської діяльності, підвищуючи рівень фінансово-економічного розвитку держави. У сукупності належне виконання усіх окреслених завдань формує конкурентоспроможність та інвестиційну привабливість країни на міжнародному рівні, зміцнює тї імідж як вигідного стабільного партнера серед інших держав та надійного учасника міжнародних організацій, забезпечує прогресивний соціально-економічний розвиток. Така функціональна багатогранність митної сфери чітко відокремлює її місце у структурі держави та ідентифікує пріоритетну роль у реалізації державної політики.
На жаль, як свідчить практика функціонування вітчизняних митних органів, на сьогодні національна митна система перебуває на етапі стагнації, характеризується чималими проблемами у різних сферах, не забезпечує належне виконання основних функцій, не відображає міжнародні та європейські стандарти. В умовах європейської інтеграції така ситуація $є$ неприпустимою та вимагає масштабного реформування митної системи України на засадах врахування кращого зарубіжного митного досвіду, впровадження загальновизнаних у світі митних принципів, правил та стандартів роботи, гармонізації митного законодавства із міжнародною та європейською нормативно-правовою базою.

\section{АНАЛІЗ ОСТАННІХ ДОСЛІДЖЕНЬ ТА ПУБЛІКАЦІЙ}

Проблеми реформування митної системи України стали предметом досліджень чималої когорти науковців, митних практиків, експертів [1-6]. На підставі ретельного вивчення наукових публікацій за митною тематикою встановлено, що наявні праці здебільшого лише частково розкривають певні аспекти модернізації національної митної системи або вже втратили актуальність 3 огляду на динамічний розвиток міжнародного та вітчизняного митного середовища. Тоді як, існуючі практичні матеріали в основному відображають лише конкретні рекомендації щодо реформування митних органів держави без наукового обгрунтування. Це відповідно не забезпечує комплексності та системності під час реформування митних органів, що передбачало б охоплення та взаємодію усіх невід'ємних структурних елементів реформаторського процесу. На сьогодні нерідко простежуються ситуації, за яких при реформуванні певної сфери митної системи не забезпечується органічне поєднання та імплементація усіх необхідних заходів, здебільшого реформаторські дії $є$ поодинокими та не пов'язуються з іншими заходами або реалізуються без належного супроводу. Ао прикладу, при запровадженні певного заходу відсутнє належне нормативно-правове забезпечення його реалізації, або навпаки. Крім того, втрачається логіка та структурованість реформування національної митної системи, що не забез- 
печує впорядкованості та поетапності реалізації реформаторських дій, провокує хаос і таким чином не відображає почерговості імплементації реформаторських заходів, не враховує їх масштабності та не забезпечує пріоритетності впровадження

\section{ЦІЛІ ДОСЛІДЖЕННЯ}

Усе вищевикладене формулює цілі дослідження як розроблення науково обгрунтованих засад реформування національної митної системи, котрі б відображали пріоритетні сфери модернізації в умовах європейської інтеграції, враховували усі невід'ємні елементи реформаторського процесу, обгрунтовували їхнє змістове наповнення та функціональне призначення, розкривали механізм взаємодії та взаємозв'язків.

\section{ВИКЛАД ОСНОВНОГО МАТЕРІАЛУ ДОСЛІДЖЕННЯ}

Одним із невід'ємних принципів реформування національної митної системи є наукова аргументованість реалізації цього процесу, що зумовлює необхідність визначення обгрунтованого концептуального підходу, який формуватиме цілісне й комплексне бачення реформаторського процесу, забезпечуватиме логіку його здійснення та дасть змогу одержати максимально ефективні результати модернізації митної сфери. Виконання означених завдань найбільшою мірою втілюється саме у системному підході, котрий на сьогодні $є$ загальновідомим та широко використовується у науковій та прикладній сферах. Ідея системного підходу полягає у побудові цілісної структури досліджуваного об'єкта, що передбачає охоплення його базових невід'ємних елементів та репрезентує механізм їхньої взаємодії і взаємозв'язків задля досягнення елементних та комплексних цілей.

На сьогодні як у науковій, так і практичній термінології поширеним є поняття "митна система", що характеризує митну сферу як комплексне явище, котре об'єАнує широкий спектр різноманітних елементів, що забезпечують виконання їі функціонального призначення. Результати спеціалізованих досліджень, які відображають наявність істотних проблем у різних сферах національної митної системи, та усе вищевикладене доводять доцільність застосування системного підходу до розгляду митної сфери у контексті її реформування. Це забезпечуватиме врахування усіх пріоритетних векторів, у яких простежуються істотні проблеми, розробити цільові заходи щодо модернізації та удосконалення кожного напряму і таким чином реалізувати комплексне реформування, що дасть змогу досягнути виходу національної митної системи із стагнаційного стану на якісно новий етап розвитку.

Таким чином, у контексті реформування митної справи України доцільно побудувати національну митну систему та здійснити її структурну декомпозицію за топологічно-змістовою ознакою, що передбачатиме виокремлення ключових структурних підсистем. Варто зауважити, що при розробленні митної системи держави слід застосовувати саме динамічний підхід, котрий, на відміну від статичного підходу, дає змогу сформувати не лише структуру системи як сукупність певних елементів, але й відобразити їхню взаємодію, взаємозв'язки, зміни, перетворення та розвиток. Розгляд митної системи України за динамічним підходом дасть змогу забезпечити її поступову гармонізацію із європейськими нормами і стандартами, що є невід'ємною умовою європейської інтеграції.

3 огляду на вищевиокремлені існуючі недоліки, проблеми і слабкі сторони реформування митної сфери в Україні та специфіку системного підходу запропоновано розглядати національну митну систему як складну цілісну контрольовану структуру, що відображає сукупність базових та забезпечувальних підсистем 3 притаманними їм елементами, які розвиваються під впли- вом внутрішніх та зовнішніх чинників та у взаємодії забезпечують виконання іманентних митних функцій. Означене визначення було сформульовано у цілях реформування та розвитку митної системи за пріоритетними сферами в умовах європейської інтеграції і таким чином акцентує увагу на їі змістовій сутності, виокремлюючи ключові підсистеми за топологічно-змістовою ознакою. Варто зауважити, що митна система держави характеризується наявністю базових підсистем, що відображають їі властиве митне призначення та ключові функції, а також забезпечувальних підсистем, котрі формують підгрунтя, супроводжують та забезпечують потреби функціонування іманентних підсистем.

На підставі вивчення спеціалізованої літератури з митної тематики та практики функціонування митних органів виконано структурну декомпозицію митної системи за топологічно-змістовою ознакою, що дало змогу виокремити базові підсистеми (контрольно-регулююча, безпеково-захисна, сервісна, фіскальна підсистеми) та забезпечувальні підсистеми (нормативно-правова, адміністративна, фінансова, інформаційно-статистична, комунікаційна, матеріально-технічна підсистеми, підсистема міжнародного співробітництва) (рис. 1).

Нормативно-правова підсистема є невід'ємним елементом митної системи, оскільки усі митні операції у будь-якій сфері реалізовуються відповідно до закріплених у регулятивних документах положень. Таким чином, нормативно-правова підсистема фактично визначає та супроводжує роботу функціонування усіх інших підсистем митної системи, що вимагає забезпечення їхньої змістової і часової відповідності та кореляції. Ця підсистема репрезентує нормотворчу функцію органів влади національного та міжнародного рівня та охоплює увесь спектр нормативно-правових документів (законів, постанов, положень, розпоряджень, інструкцій, директив, конвенцій, актів тощо), котрі прямо чи опосередковано регулюють митну діяльність різних суб'єктів (митних органів, суб'єктів зовнішньоекономічної діяльності, митних посередників тощо). В умовах динамічного розвитку національного та міжнародного митного середовища нормативно-правова підсистема повинна постійно переглядатись, оновлюватись та удосконалюватись. Крім того, важливим є забезпечення не лише її актуалізованості, але й гармонізованості із міжнародними нормативно-правовими документами, об'єктивності, неупередженості, внутрішньої несуперечливості та однозначності трактування.

Адміністративна підсистема охоплює органи управління митною діяльністю на усіх рівнях, відображаючи структурне наповнення рівнів управління, ієрархію та централізованість управління, горизонтальні та вертикальні зв'язки між рівнями управління, функціональне навантаження та сферу відповідальності митних працівників. У межах цієї підсистеми здійснюється управління митною діяльністю на засадах реалізації ключових функцій - планування, організування, мотивування, контролювання та регулювання. Тобто суб'єкти адміністративної підсистеми визначають ключові вектори, цілі та завдання розвитку національної митної системи загалом та її окремих сфер, організовують та координують роботу митного персоналу, здійснюють контроль за реалізацією митних операцій та регулюють будь-які правопорушення у митній сфері, тощо. Ефективність функціонування цієї підсистеми визначає результати здійснення митної справи в державі. Функціонування адміністративної підсистеми регулюється Митним кодексом України [7], Положенням "Про Аержавну фіскальну службу України" [8] та іншими нормативноправовими актами. На сьогодні адміністративна підсистема митної системи України ієрархічно сформована із Кабінету Міністрів України в особі Міністра фінансів, Аержавної фіскальної служби України, територіальних органів Аержавної фіскальної служби України, представлених обласними митницями, митними постами та 


\section{НАЦІОНАЛЬНА МИТНА СИСТЕМА}

\section{ОСНОВНІ ПІДСИСТЕМИ}

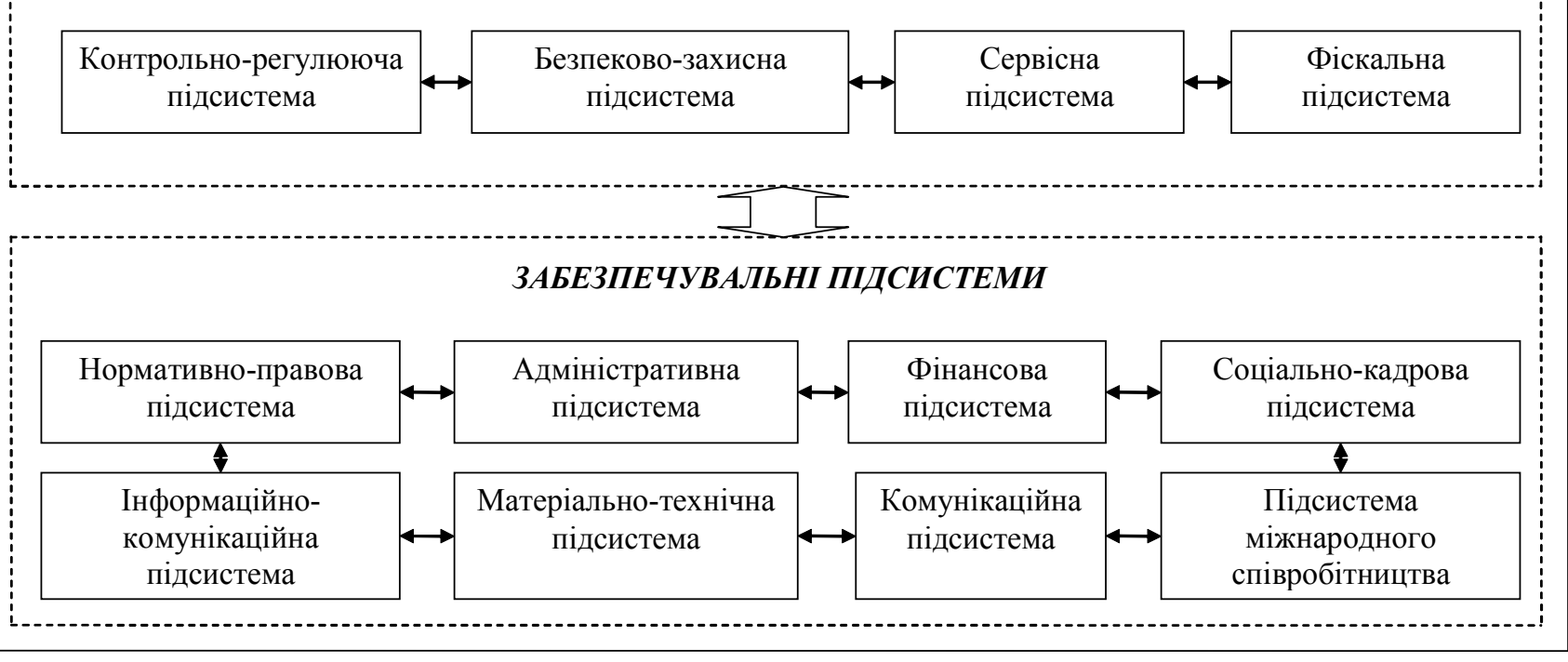

Рис. 1. Структурна декомпозиція національної митної системи за топологічно-змістовою ознакою

відділами митного оформлення.

Контрольно-регулююча підсистема грунтується на реалізації широкого спектру контрольних та регулюючих процедур у митній сфері з метою забезпечення дотримання положень законодавства під час переміщення товарів і транспортних засобів комерційного призначення через митний кордон держави. Призначення цієї підсистеми розкриває одну із базових іманентних функцій митної системи держави та є одним із невід'ємних постулатів державної митної справи, що передбачає реалізацію різних форм і видів митного контролю та регулювання зовнішньоекономічної діяльності. При цьому, визначення товарів чи транспортних засобів комерційного призначення, які підлягатимуть митному контролю, відбувається за результатами управління ризиками у митній сфері, особливості якого регулюються Главою 53 Митного кодексу України [7]. Аля реалізації митними органами контрольної функції ст. 329 цього Кодексу [7] передбачено створення спеціальних зон митного контролю. Відповідно до ст. 336 Кодексу [7] на сьогодні визначено такі ключові форми митного контролю, як перевірка документів та відомостей про переміщення товарів чи транспортних засобів комерційного призначення через митний кордон України; митний огляд; облік товарів, транспортних засобів комерційного призначення; усне опитування громадян чи працівників підприємств; огляд територій та приміщень, де знаходяться підконтрольні об'єкти; перевірка обліку підконтрольних об'єктів; документальна перевірка; спрямування запитів до інших державних органів, установ та організацій для підтвердження автентичності документів. У межах митного контролю передбачено також митні експертизи, що забезпечують взяття проб (зразків) товарів та здійснення операцій з узятими пробами.

Безпеково-захисна підсистема втілює ще одну ключову іманентну функцію митної системи, що стосується забезпечення національної безпеки та захисту суспільства від шкідливих та неякісних товарів. У межах цієї підсистеми реалізовуються заходи щодо запобігання та протидії контрабанді, захисту прав інтелектуальної власності на товари, що переміщуються через митний кордон держави, визначення обсягу відповідаль- ності за порушення митних правил, притягнення до відповідальності правопорушників, провадження справ про порушення митного законодавства, тощо. Функціонування безпеково-захисної підсистеми здійснюється відповідно до положень Розділу XIV "Сприяння захисту прав інтелектуальної власності під час переміщення товарів через митний кордон країни", Розділу XVII "Запобігання та протидія контрабанді", Розділу XVIII "Порушення митних правил та відповідальність за них", Розділу XIX "Провадження у справах про порушення митних правил" Митного кодексу України [7] та інших нормативно-правових актів.

Сервісна підсистема репрезентує сукупність митних процесів, операцій, процедур та дій, які реалізовуються для забезпечення митного оформлення товарів чи транспортних засобів комерційного призначення, що переміщуються через митний кордон держави. Призначення цієї підсистеми відображає одну із базових іманентних функцій митної системи держави, що стосується професійного надання високоякісних прогресивних митних послуг суб'єктам зовнішньоекономічної діяльності 3 метою активізації та сприяння здійсненню легальної міжна родної торгівлі. Ао ключових митних послуг, які надаються митними органами підприємствам, можна віднести послуги щодо акредитації та переакредитації суб'єктів зовнішньоекономічної діяльності у митних органах, видачі та перевірки сертифікаційнодозвільної документації, контролю, перевірки та коригування митних декларацій, митної вартості товарів та обсягів митних платежів, коду товару відповідно до УКТ 3ЕА, поміщення товарів на складах митних органів, тощо [9]. Ключовим нормативно-правовим документом, що визначає особливості функціонування сервісної підсистеми є Митний кодекс України у розрізі I-VIII Розділів [7]. 3 огляду на швидкі темпи зміни науковотехнічного прогресу та відповідно високодинамічний розвиток митного середовища важливо забезпечувати перманентне удосконалення та модернізацію роботи сервісної підсистеми у митній сфері з метою підвищення ефективності тї функціонування на засадах запровадження інноваційних митних технологій та інструментів обслуговування суб'єктів зовнішньоекономічної діяльності. 
Фіскальна підсистема забезпечує управління митними платежами у формі податків та зборів, які підлягають сплаті суб'єктами зовнішньоекономічної діяльності, на засадах встановлення ставок і тарифів таких платежів, визначення їхніх видів та порядку стягнення, перевірки повноти сплати, а також цільового спрямування до державного бюджету або на інші цілі. Призначення цієї підсистеми частково відображає регулюючу функцію митних органів у розрізі тарифного регулювання зовнішньоекономічної діяльності та пов'язане із підвищенням рівня економічної безпеки держави. Ключові засади справляння митних платежів та інших податків у зовнішньоекономічній сфері (податку на прибуток, податку на додану вартість, акцизного податку) визначені Розділом IX Митного кодексу України [7] та Розділами IV - VI Податкового кодексу України [10].

Фінансова підсистема відображає фінансове забезпечення роботи митних органів та розвитку митної справи в державі та розкриває рух грошових потоків для забезпечення потреб національної митної системи. Призначення цієї підсистеми пов'язане із плануванням доходів і витрат митних органів, контролем за їхнім обсягами на засадах порівняння планових і фактичних значень, залученням зовнішніх джерел фінансування, їхнім спрямуванням у найбільш пріоритетні сфери, забезпеченням цільового використання фінансових ресурсів, тощо. Фінансування потреб діяльності митних органів забезпечується за рахунок коштів державного бюджету та визначається Законом України про державний бюджет на відповідний рік. Ключовим розпорядником фінансових ресурсів митних органів є Аержавна фіскальна служба України. При цьому, будь-яка державна установа зобов'язана складати кошторис надходжень та видатків, особливості формування, затвердження та виконання якого регулюються відповідною Постановою Кабінету Міністрів України.

Інформаційно-статистична підсистема передбачає ведення обліку роботи митних органів та зовнішньоекономічної діяльності у розрізі товарів і транспортних засобів комерційного призначення, що переміщуються через митний кордон держави, з метою формування систематизованої інформаційної бази та за необхідності надання даних іншим державним органам влади, міжнародним організаціям та митним органам зарубіжних держав. Призначення цієї підсистеми пов'язано із запобіганням та протидією незаконному переміщенню заборонених законодавством небезпечних чи шкідливих товарів на засадах оперативної інформаційно-комунікаційної взаємодії зацікавлених суб'єктів, а також формуванням інформаційного забезпечення розвитку міжнародних економічних зв'язків держави та зовнішньоекономічної діяльності підприємств. Це дає змогу підвищувати рівень національної безпеки та захисту держави і її громадян, економічного розвитку та міжнародної конкурентоспроможності держави. Слід зазначити, що ведення митної статистики передбачено Розділом XVI Митного кодексу України [7].

Соціально-кадрова підсистема визначає якісний i кількісний склад персоналу митних органів та рівень його соціального забезпечення. В межах цієї підсистеми відбувається добір, прийняття на роботу, переміщення за посадами, звільнення, підвищення рівня кваліфікації митних працівників, а також матеріальне і нематеріальне мотивування за результатами їхньої роботи. Функціонування соціально-кадрової підсистеми національної митної системи здійснюється відповідно до положень Закону України "Про державну службу" [11] огляду на те, що працівники митних органів належать до когорти державних службовців, а також Глав 79-83 Митного кодексу України [7]. Зокрема у Законі визначено правовий статус державного службовця, особливості прийняття на державну службу, проходження та припинення державної служби, оплати праці, надання заохочень і соціальних гарантій державним службов- цям, коло їх дисциплінарної та матеріальної відповідальності. Своєю чергою, Митний кодекс України [7] регулює засади проходження служби в органах доходів і зборів, одержання професійної освіти у сфері державної митної справи, правового і соціального захисту працівників митних органів. Варто зауважити, що якість функціонування соціально-кадрової підсистеми визначає ефективність реалізації усіх митних операцій в межах митної системи держави;

Комунікаційна підсистема репрезентує механізми взаємодії та комунікування митних органів 3 іншими суб'єктами (органами державної влади та місцевого самоврядування, суб'єктами підприємницької діяльності) задля забезпечення ефективного здійснення митної діяльності. Особливості таких взаємовідносин регулюються Главою 77 Митного кодексу України [7]. Мова йде про налагодження взаємної співпраці із правоохоронними та іншими органами влади і установами (Службою безпеки України, Національної поліцією, Аержавною прикордонною службою України, Національним Антикорупційним Бюро України, судовими органами та іншими установами) у контексті забезпечення оперативного виявлення та протидії митним правопорушенням і контрабанді. Крім того, в межах цієї підсистеми повинна організовуватись взаємодія із суб'єктами зовнішньоекономічної діяльності у формі консультування та інформування підприємств, залучення до розвитку методів роботи митних органів, вирішення проблем у митній сфері, удосконалення нормативно-правової бази тощо.

Матеріально-технічна підсистема відображає рівень матеріально-технічного забезпечення митних органів та рівень розвитку митної інфраструктури. Призначення цієї підсистеми полягає у формуванні достатньої матеріально-технічної бази та митної інфраструктури для забезпечення нормальної роботи митних органів на різних рівнях та у всіх регіонах, що включатиме необхідну кількість високотехнологічних та простих засобів митного контролю, комп'ютерної техніки, оперативного транспорту, пунктів пропуску належного стану, спільних митних постів. У межах цієї підсистеми повинні систематично реалізовуватись завдання щодо відстеження рівня матеріально-технічного забезпечення у митній сфері та митної інфраструктури, перманентного оновлення застарілої техніки та приладдя, розбудови пунктів пропуску тощо.

Підсистема міжнародного співробітництва відображає рівень розвитку взаємодії національних митних органів із митними органами суміжних та інших держав, а також їхньої участі у міжнародних організаціях, міжнародних митних проектах, торгових місіях, тощо. Особливості такої співпраці визначені Главою 78 Митного кодексу України [7]. Призначення цієї підсистеми пов'язане із налагодженням ефективного та взаємовигідного співробітництва із міжнародними організаціями та митними органами зарубіжних країн задля перейняття кращого митного досвіду, одержання конкретних фахових рекомендацій та залучення фінансових ресурсів для модернізації національної митної системи, розбудови митної інфраструктури, а також репрезентації державних митних інтересів на міжнародному рівні.

\section{ВИСНОВКИ ТА ПЕРСПЕКТИВИ ДОСЛІДЖЕНЬ}

Сучасний етап функціонування національної митної системи відображає існування вагомих проблем за різними їі сферами. Не зважаючи на численні спроби модернізувати роботу митних органів представниками різних рівнів, на жаль видимого результату не вдалось досягнути. Особливо критично проблема реформування національної митної системи постала в умовах європейської інтеграції, адже із підписанням та ратифікацією Угоди про асоціацію із Европейським Союзом Україна взяла на себе зобов'язання гармонізувати митну сферу із європейськими стандартами та нормами. 3 
огляду на існуючі невдалі та безуспішні спроби удосконалити роботу митних органів доведено, що процес реформування повинен бути науково обгрунтованим. Застосування наукового підходу забезпечуватиме цілісне, завершене, комплексне та структуроване бачення реформаторського процесу, ідентифікуватиме та обгрунтовуватиме пріоритетні сфери модернізації та дасть змогу досягнути максимально ефективних результатів. На підставі вивчення існуючих проблем у вітчизняному досвіді модернізації роботи митних органів, аналізування класичних і сучасних наукових теорій, врахування тенденцій європейської інтеграції рекомендовано використовувати системний підхід до реформування митної сфери. Запропоновано розглядати національну митну систему як складну цілісну контрольовану структуру, що відображає сукупність базових та забезпечувальних підсистем з притаманними їм елементами, які розвиваються під впливом внутрішніх та зовнішніх чинників та у взаємодії забезпечують виконання іманентних митних функцій. 3 метою розкриття змістового наповнення та функціонального призначення підсистем національної митної системи виконано її структурну декомпозицію за топологічно-змістовою ознакою, що сформувало систематизовану інформаційну базу для подальшого реформування вітчизняної митної сфери. Зокрема виокремлено базові підсистеми (контрольно-регулююча, безпеково-захисна, сервісна, фіскальна підсистеми) та забезпечувальні підсистеми (нормативно-правова, адміністративна, фінансова, інформаційно-статистична, комунікаційна, матеріально-технічна підсистеми, підсистема міжнародного співробітництва).

Перспективами подальших досліджень є розроблення та обгрунтування цільових рекомендацій щодо реформування та гармонізації кожної підсистеми національної митної системи із європейськими митними стандартами, нормами, правилами та принципами.

\section{\ітература:}

1. Макаренко A.В. Митна реформа: пошук оптимальної концепції/ A.B. Макаренко // LEX PORTUS. - 2017. - № 2 (4). - C. 21-36.

2. Мельник О.Г. Система управління митною діяльністю в Україні: сутність та структурна декомпозиція / О.Г. Мельник, О.В. Мукан, Х.В. Кабан //Вісник Національного університету " $\Lambda$ ьвівська політехніка". Серія "Менеджмент та підприємництво в Україні: етапи становлення і проблеми розвитку". - 2013. - № 776. C. $39-47$.

3. Шамборовський Г.О. Реформування митної служби в Україні в умовах європейської економічної інтеграції / Г.О. Шамборовський // Інвестиції: практика та досвід. - 2016. - № 18. - С. $27-31$.

4. Керівні принципи для митної справи в Україні/ Американська торговельна палата в Україні, Представництво міжнародного кредитно-рейтингового агентства Ernst\&Young в Україні, 2018 [Електронний ресурс]. - Режим доступу: https://www.ey.com/Publication/vwLUAssets/eyguidelines-for-customs-policy-in-ukraine-ua/ \$FILE/ eyguidelines-for-customs-policy-in-ukraine-ua.pdf

5. Презентаційні матеріали Аержавної фіскальної служби України "Стратегічні ініціативи розвитку Аержавної фіскальної служби України до 2020 р." [Електронний ресурс]. - Режим доступу: http://sfs.gov.ua/ data/files/218923.pdf

6. Проект Міністерства фінансів України "План дій 3 реформування митниці", 2017 [Електронний ресурс]. - Режим доступу: https://www.kmu.gov.ua/storage/app/ imported content/news/doc 250141228/\%D0\%9F $\%$ D0 $\%$ BB $\% \overline{\mathrm{D}} 0 \% \mathrm{~B} 0 \% \mathrm{D} 0 \% \mathrm{BD} \% 2 \overline{0} \% \mathrm{D} 0 \% \mathrm{~B} 4 \mathrm{i} \% \mathrm{D} 0 \% \mathrm{~B} 9 \% 20-$ $\% 20 \% \mathrm{D} 0 \% \mathrm{BC} \% \mathrm{D} 0 \% \mathrm{~B} 8 \% \mathrm{D} 1 \% 82 \% \mathrm{D} 0 \% \mathrm{BD} \% \mathrm{D} 0 \% \mathrm{~B} 8 \%-$ D1\%86\%D1\%8F.pdf

7. Митний кодекс України № 4495-VI від 13.03.2012 p. [Електронний ресурс]. - Режим доступу: http:/ zakon.rada.gov.ua/laws/show/4495-17
8. Положення "Про Аержавну фіскальну службу України", затверджене Постановою Кабінету Міністрів України № 236 від 21.05.2014 р. [Електронний ресурс]. - Режим доступу: http://zakon.rada.gov.ua/laws/show/ 236-2014-\%D0\%BF

9. Кузьмін О.Є. Типологія митного обслуговування підприємств / О.Є. Кузьмін, О.Ф. Будз // Вісник Національного університету " $\Lambda$ ьвівська політехніка". Серія: Менеджмент та підприємництво в Україні: етапи становлення і проблеми розвитку. ництво Аьвівської політехніки, 2017. - № 875. - С. $3-12$.

10. Податковий кодекс України № 2755-VI від 2.12.2010 р. [Електронний ресурс]. - Режим доступу: http://zakon.rada.gov.ua/laws/show/2755-17

11. Закон України "Про державну службу" № 889VIII від 10.12.2015 р. [Електронний ресурс]. - Режим доступу: http://zakon.rada.gov.ua/laws/show/889-19

\section{References:}

1. Makarenko, A.V. (2017), "The customs reform: searching for the optimal conception", LEX PORTUS, vol. 2 (4), pp. $21-36$.

2. Melnyk, O.H. Mukan O.V. and Kaban, Kh.V. (2013), "The system of customs activity management in Ukraine: the essence and structural decomposition", Visnyk Natsional'noho universytetu "L'vivs'ka politekhnika". Seriia: Menedzhment ta pidpryiemnytstvo v Ukraini: etapy stanovlennia i problemy rozvytku, No 776, pp. 39-47.

3. Shamborovkyi, H.O. (2016), "Reformation of the customs service in Ukraine in terms of European economic integration", Investytsii: praktyka ta dosvid, vol. 18, pp. $27-$ 31.

4. The American Chamber of Commerce in Ukraine and the Official Office of International Credit Rating Agency Ernst\&Young in Ukraine (2018), "Guidelines for customs policy in Ukraine", available at: https://www.ey.com/ Publication/vwLUAssets/ey-guidelines-for-customspolicy-in-ukraine-ua/ \$FILE/ ey-guidelines-for-customspolicy-in-ukraine-ua.pdf (Accessed 15 October 2018).

5. The official site of the State Fiscal Service of Ukraine (2017), "Strategic initiatives of development of the State Fiscal Service of Ukraine till 2020", available at: http:// sfs.gov.ua/data/files/218923.pdf (Accessed 25 October 2018).

6. The Ministry of Finance of Ukraine (2017), "Draft Customs Reform Action Plan", available at: https:// www.kmu.gov.ua/storage/app/imported content/news/ doc $250141228 / \% \mathrm{D} 0 \% 9 \mathrm{~F} \% \mathrm{D} 0 \% \mathrm{BB} \% \mathrm{D} 0 \% \mathrm{~B} 0 \% \mathrm{D} 0 \% \mathrm{BD} \%-$ $20 \%$ D $0 \%$ B 4 i \% D $0 \%$ B $9 \% 20-\% 20 \%$ D $0 \%$ B C \% D0\%B8\%D1\%82\%D0\%BD \%D0\%B8\%D1\%86\%D1\%8F.pdf (Accessed 10 October 2018).

7. The Verkhovna Rada of Ukraine (2012), The Customs Code of Ukraine No 4495-VI, available at: http:/ zakon.rada.gov.ua/laws/show/4495-17 (Accessed 22 September 2018).

8. Cabinet of Ministers of Ukraine (2014), "Resolution of the Cabinet of Ministers of Ukraine "On the State Fiscal Service of Ukraine"" No 236, available at: http://zakon.rada.gov.ua/laws/show/2755-17 (Accessed 3 October 2018).

9. Kuzmin, O.Ye. and Budz, O.V. (2017), "Typology of customs services of enterprises", Visnyk Natsional'noho universytetu "L'vivs'ka politekhnika". Seriia: Menedzhment ta pidpryiemnytstvo v Ukraini: etapy stanovlennia i problemy rozvytku, No 875 , pp. 3-12.

10. The Verkhovna Rada of Ukraine (2010), The Tax Code of Ukraine No 2755-VI, available at: http:// zakon.rada.gov.ua/laws/show/2755-17 (Accessed 30 September 2018).

11. The Verkhovna Rada of Ukraine (2015), The Law of Ukraine "On State Service", No 889-VIII, available at: http://zakon.rada.gov.ua/laws/show/2755-17 (Accessed 2 October 2018).

Стаття надійшла до редакиї 13.11.2018 p. 
1. Є. Фурдичко, к.е.н., дочент, дочент кафедри фінансів, Начіональний університет " Аьвівсъка політехніка" O. M. Піхоивка, к.е.н., дочент, дочент кафедри фінансів, Начіональний університет " Аъвівсъка політехніка"

\title{
ПРИЧИНИ ЗРОСТАННЯ АЕРЖАВНОГО БОРГУ, ЙОГО УПРАВАІННЯ І ОБСАУГОВУВАННЯ, ОПТИМІЗАЦІЯ БОРГОВОЇ ПОАІТИКИ УКРАЇНИ
}

\author{
L. Furdychko, \\ Candidate of economic sciences, \\ associate Professor of Finance National University "Lviv Polytechnic" \\ O. Pikhotska, \\ Candidate of economic sciences, \\ associate Professor of Finance National University "Lviv Polytechnic"
} CAUSES OF DEVELOPMENT OF THE PUBLIC DEBT, ITS MANAGEMENT AND SERVICE,
OPTIMIZATION OF UKRAINE'S FOREIGN POLICY

\footnotetext{
Статтю присвячено формуванню та зростанню державному боргу істану боргової політики України. Держава Аля фінансування та покриття витрат на управління та обслуговування,державного боргу повинна знайти додаткові джерела фінансових ресурсів, які б забезпечили скорочення боргового тягаря та сприяли б розвитку національної економіки. Аля України державний борг є великою гострою фінансово-економічною проблемою. ААже він перешкоджає економічному росту країни, погіршує ї̈ фінансове становище та гальмує розвиток України в майбутньому.

В умовах затяжної кризи в Україні, відбулось зростання та накопичення державного боргу, що негативно вПлинуло на боргову і фінансово-економічну політикув цілому. Така Ситуація вимагає формування середньо- і довгострокої стратегії боргової політики, в основі якої має бути підвищення боргової стійкості та фінансової безпеки держави. Аля цього необхідно мінімізувати ризики з коливання валютного курсу в Украӥні, девальвації гривні; оптимізувати структуру державного боргу; змінити систему УПравління і його обсл уговування; знаходити нові джерела зал учення коштів в економікукраїни. Боргова Політика має здійснюватись У тісному взаємозв'язкУ із фіскальною і грошово-кредитною політикою, які в такій взаємодії залежать одна від одної і впливають на розвиток України.

У міжнародній практиці використовують різні показники оцінки станудержавного боргу. За вимогами Маастрихтського договору, державний борг не повинен перевищувати 60\% валового внутрішнього продукту, а Світовий банк критичним рівнем державного зовнішнього боргу вважає $50 \%$ від валового внутрішнього продукту.
}

The article is devoted to the formation and growth of the state debt and the state of debt policy of Ukraine. The state to finance and cover the costs of managing and servicing the public debt should find additional sources of financial resources that would reduce the debt burden and contribute to the development of the national 
economy. For Ukraine, public debt is a major acute financial and economic problem. After all, it hinders economic growth of the country, worsens its financial situation and hinders the development of Ukraine in the future. In the conditions of a prolonged crisis in Ukraine, the growth and accumulation of public debt took place, which negatively affected the debt and financial and economic policy in general. This situation requires the formation of a medium - and long-term strategy of debt policy, which should be based on increasing the debt sustainability and financial security of the state.

To do this, it is necessary to minimize the risks of fluctuations in the exchange rate in Ukraine, devaluation of the hryvnia; optimize the structure of public debt; change management system and its main tenance; find new sources of raising funds in the economy of the country. Debt policy should be carried out in close relation with fiscal and monetary policy, which in such interactions depend on one and affect the development of Ukraine.

In international practice, various indicators of state debt assessment are used.According to the requirements of the Maastricht Agreement, the state debt should not exceed 60\% of gross domestic product, and the World Bank considers the critical level of public external debt to be $50 \%$ of gross domestic product.

Ключові слова: обсяг державного боргу, управління державного боргу, обслуговування державного боргу, боргова політика, боргова безпека, державні запозичення.

Key words: volume of state debt, public debt management, state debt service, debt policy, debt security, state borrowing.

\section{ПОСТАНОВКА ПРОБЛЕМИ}

Аержавний борг є важливою складовою фінансової системи. Він виступає дієвим інструментом у механізмі макроекономічного регулювання, забезпечення додатковими ресурсами і засобом реалізації економічної стратегії держави. Управління та обслуговування державного боргу є важливим завданням економічної, боргової політики, умовою стабільності її фінансової системи, особливо в сучасному періоді розвитку України. Основними проблемами управління та обслуговування державного боргу в Україні є: великий обсяг державного боргу і його постійне зростання; недосконала законодавча база, яка потребує змін; неврегульований механізм реструктуризації боргу і його обслуговування в співвідношенні до реальних макроекономічних показників соціально-економічного розвитку країни. Все це негативно впливає на фінансове становище країни та перешкоджає економічному розвитку України на перспективу.

\section{АНАЛІЗ ОСТАННІХ ДОСЛІДЖЕНЬ І ПУБЛІКАЦІЙ}

Аослідженням проблематики щодо державного боргу, аналізу і механізму управління та обслуговування його, присвячені наукові праці українських вчених, якот: О.В. Борисюка, Н.В. Зражевської, В.П. Каменської,

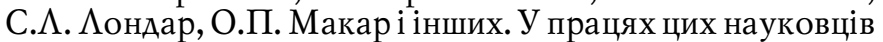
розкрито вплив різних чинників на формування державного боргу, на напрями управління державним боргом в Україні, зроблено оцінку і визначено прогнози державного боргу на майбутнє.

\section{НЕВИРІШЕНІ ЧАСТИНИ ПРОБЛЕМИ}

Питання проблеми формування державного боргу в Україні та всі процеси пов'язані з ним на сьогодні $€$ дуже актуальними, адже 3 кожним роком боргові зобов'язання України зростають і, відповідно, зростають витрати на його управління та обслуговування. Найбільш гостро в сучасній Україні стоїть питання ефективного визначення її боргової політики щодо залучення і витрачання державних запозичень.

\section{МЕТА ДОСЛІДЖЕННЯ}

Метою дослідження $є$ формування і накопичення внутрішнього і зовнішнього державного боргу України, його управління і обслуговування та визначення стратегічних напрямів боргової політики країни на майбутнє шляхом скорочення державних запозичень.

\section{ОСНОВНІ РЕЗУЛЬТАТИ ДОСЛІДЖЕННЯ}

Рівень розвитку національної економіки оцінюється мірою використання національного багатства для забезпечення національної безпеки, високого рівня якості життя населення і конкурентоспроможності країни на міжнародних ринках. Наявність державного боргу, його розміри впливають на всі сторони життя країни.

Розвиток України сьогодні відбувається в складних економічних, соціальних і політичних умовах. Аержавний борг України сформувався і продовжує зростати під впливом певних факторів, в основі яких є соціально-економічна, політична кризи; криза державних фінансів і грошово-кредитної системи; послаблення фінансової стійкості і рівноваги; дефіцити торговельного і платіжного балансів; хронічний дефіцит державного балансу тощо. Все це впливає на недоотримання відповідного обсягу валового внутрішнього продукту, обсягів фінансових ресурсів на макро- - макрорівнях, на зростання інфляції, росту дефіциту державного бюджету та державного боргу та, відповідно, на погіршення добробуту громадян.

Стан державного боргу України регулюється рядом нормативно-правових актів, основними 3 яких є Конституція України, Закон України "Про Аержавний внутрішній борг", Закон України "Про структуру внутрішнього державного боргу України", Бюджетний кодекс України, Закон України "Про Аержавний бюджет на 2017 рік", Закон України "Про Національний банк України" тощо.

Відповідно до Бюджетного кодексу України, "державний борг - загальна сума заборгованості держави, яка складається з усіх випущених і непогашених боргових зобов'язань держави, включаючи боргові зобов'я- 
Таблиця 1. Показники державного і гарантованого державою боргу України за 2010-2017 роки

\begin{tabular}{|l|c|c|c|c|c|c|c|c|c|}
\hline \multirow{2}{*}{ Роки } & \multicolumn{2}{|c|}{$\begin{array}{c}\text { Державний } \\
\text { внутрішній } \\
\text { борг }\end{array}$} & \multicolumn{2}{c|}{$\begin{array}{c}\text { Державний } \\
\text { зовнішній } \\
\text { борг }\end{array}$} & $\begin{array}{c}\text { Гарантований } \\
\text { державою } \\
\text { борг }\end{array}$ & $\begin{array}{c}\text { Курс } \\
\text { долара до } \\
\text { гривні }\end{array}$ & \multicolumn{2}{|c|}{$\begin{array}{c}\text { Державний і } \\
\text { гарантований } \\
\text { державоюборг }\end{array}$} \\
\cline { 2 - 11 } & $\begin{array}{c}\text { млрд } \\
\text { грн }\end{array}$ & $\begin{array}{c}\text { млрд } \\
\text { дол }\end{array}$ & $\begin{array}{c}\text { млрд } \\
\text { грн }\end{array}$ & $\begin{array}{c}\text { млрд } \\
\text { дол }\end{array}$ & $\begin{array}{c}\text { млрд } \\
\text { грн }\end{array}$ & $\begin{array}{c}\text { млрд } \\
\text { дол }\end{array}$ & $\begin{array}{c}100 \\
\text { дол }\end{array}$ & $\begin{array}{c}\text { млрд } \\
\text { грн }\end{array}$ & $\begin{array}{c}\text { млрд } \\
\text { дол }\end{array}$ \\
\hline 2010 & 141,7 & 17,9 & 181,8 & 22,9 & 108,8 & 13,7 & 793,6 & 432,3 & 54,5 \\
\hline 2011 & 161,5 & 20,3 & 195,8 & 24,6 & 115,8 & 14,5 & 796,8 & 473,1 & 59,4 \\
\hline 2012 & 190,5 & 24,5 & 208,9 & 26,8 & 116,3 & 14,9 & 779,1 & 515,7 & 66,2 \\
\hline 2013 & 257,0 & 32,2 & 223,3 & 28,0 & 104,6 & 13,1 & 799,0 & 584,9 & 73,3 \\
\hline 2014 & 461,0 & 29,3 & 486,0 & 30,8 & 153,0 & 9,8 & 1576,0 & 1100 & 69,9 \\
\hline 2015 & 508,0 & 24,1 & 825,9 & 39,5 & 237,9 & 11,3 & 2109,6 & 1571,8 & 74,9 \\
\hline 2016 & 670,6 & 26,6 & 980,2 & 38,9 & 278,9 & 11,1 & 2520,0 & 1929,7 & 76,6 \\
\hline 2017 & 689,4 & 25,6 & 970,3 & 36,1 & 311,5 & 11,6 & 2696,0 & 1971,2 & 73,3 \\
\hline
\end{tabular}

Ажерело: [5].

Таблиця 2. Структура державного та гарантованого державою боргу на 31.08.2018 року

\begin{tabular}{|l|l|l|l|}
\hline \multicolumn{1}{|c|}{ млн грн. } & \multicolumn{1}{c|}{$\begin{array}{c}\text { Зовнішній } \\
\text { борг }\end{array}$} & $\begin{array}{c}\text { Внутрішній } \\
\text { борг }\end{array}$ & \multicolumn{1}{c|}{ Усього } \\
\hline Державний борг & 1070820,1 & 759063,4 & 1829883,5 \\
\hline $\begin{array}{l}\text { Гарантований } \\
\text { державою борг }\end{array}$ & 273569,0 & 13215,3 & 286784,3 \\
\hline Сукупний борг & 1344389,1 & 772278,7 & 2116667,8 \\
\hline
\end{tabular}

Ажерело: [6].

зання держави, що вступають в дію в результаті виданих гарантій за кредитами, або зобов'язання, що виникають на підставі законодавства або договору" [1].

Обсяг державного боргу регулюється законодавством України. Аля покращення управління та обслуговування зовнішнього і внутрішнього боргів бюджетним кодексом України встановлено, що основний обсяг державного боргу не повинен перевищувати $60 \%$ фактичного річного обсягу ВВП України. Крім того, граничні обсяги державного внутрішнього і зовнішнього боргів України і надання державних гарантій здійснюється в межах, що встановлюються на кожний бюджетний період [2].

Відповідно до Маастрихтського договору, співвідношення державного боргу до ВВП у Європейському Союзі повинен бути нижче $60 \%$. Середній рівень цього показника у Європейському Союзі у 2017 р. становив $81,6 \%$, а у Еврозоні - 86,7\% [11].

Співвідношення обсягу державного боргу до рівня валового внутрішнього продукту в Україні повинен бути співзвучним із цим співвідношенням Європейського Союзу, адже Україна в сучасному їі розвитку, прагне стати членом Євросоюзу в найближчій перспективі.

Боргова політика держави безпосередньо пов'язана із державними запозиченнями, які направлені на фінансування дефіциту державного бюджету, зокрема в розрізі фінансування поточних видатків, на погашення боргів минулих періодів та гарантованих державою кредитів підприємствам, в інвестиційні проекти, особливо, в галузі будівництва і лише незначна частина орієнтована на підтримку стратегічних галузей, в реальний сектор економіки та на підтримку інноваційних проектів, що позитивного впливу на ефективний розвиток економіки не справляє. Це зумовлено нечіткою стратегією боргової політики. Тому державні запозичення не мають позитивного ефекту на розвиток країни [3].

Соціально-економічний розвиток України відбувається в умовах збереження певних викликів і ризиків. Основними 3 яких можна виділити:

- загроза ескалації бойових дій на сході;

- вірогідність погіршення зовнішньоекономічної кон'юнктури на світових товарних ринках;

- міграційні процеси та інші.

Обсяг платежів 3 погашення державного боргу на 2018 рік прогнозується в розмірі 175725,5 млн грн, що на 46 166,5 млн грн більше, ніж у 2017 році, в тому числі, погашення зовнішнього державного боргу - 61 703,3 млн грн, або на 30 763,3 млн грн. більше плану на 2017 року; погашення внутрішнього державного боргу - 114024,2 млн грн, або на 15 403,2 млн грн більше плану на 2017 року [4].

Загальні виплати за державним боргом, що мають бути здійсненні у 2018 році за рахунок державного бюджету, оцінюються на рівні 305925 млн грн, з яких 193364 млн грн - виплати за внутрішнім боргом та 112 561,4 млн грн складаються виплати за зовнішнім боргом.

Враховуючи структуру державних запозичень у 2017 році та прогнозних запозичень у 2018 році, на кінець 2018 року частка внутрішнього державного боргу становитиме 37,6 \% від обсягу державного боргу, а частка зовнішнього боргу 62,4\% [4].

У таблиці 1 подано статистичні дані за останні сім років, які показують реальну картину боргу України за 2010-2017 роки.

Ця таблиця показує, що за період від 2010-2017 років, державний борг України зростав значними темпами і у 2017 році гарантований державою борг зріс майже в тричі в гривневому еквіваленті, а державний і гарантований державою борг збільшився в п'ять разів у гривневому еквіваленті і у два рази в доларах США.

У такому стані Україна має великі проблеми в фінансовій та економічно-соціальній сферах після зміни влади внаслідок трагічних подій у 2014 році. Починаючи 3 цього року і до сьогодні роки є найскладнішими для вітчизняної економіки.

За даними Міністерства фінансів України відбуватиметься зростання граничного розміру гарантованого державою боргу до кінця 2018 року у 2,3 рази і може зрости до 747,6 млрд грн, а граничний розмір державного боргу України станом на кінець 2018 року не перевищить 1,999 трлн грн. Співвідношення державного боргу до ВВП, згідно із прогнозами Міністерства фінансів, виросте $375,6 \%$ у 2017 році до 82,4\% до кінця 2018 року [6].

У Програмі управління державним боргом на 2018 рік, зазначено, що загальні виплати за державним боргом в цьому році мають бути здійснені за рахунок коштів державного бюджету та оцінюються на рівні $305925,8 \mathrm{MлH}$ грн, 3 яких 63,2\% або 193964,4 млн грн - виплати за внутрішнім боргом і 36,8\%, або 112561,4 млн грн, становлять виплати за зовнішнім боргом. Частка видатків з обслуговування державного боргу у видатках загального фонду державного бюджету на 2018 рік становитиме $14,3 \%$. В структурі загальних виплат: 
Таблиця 3. Прогнозна динаміка показників макроекономічної політики на 2018-2021 роки (\%, якщо не зазначене інше)

\begin{tabular}{|l|l|l|l|l|l|l|l|}
\hline № & \multicolumn{1}{|c|}{ Показники,\% } & \multicolumn{1}{|c|}{2016} & 2017 & 2018 & 2019 & 2020 & \multicolumn{1}{|c|}{2021} \\
\hline 1. & Реальне зростання ВВП & 2,3 & 2,9 & 3,2 & 3,5 & 4,0 & 4,0 \\
\hline 2. & Темпи зростання інфляції & 12,4 & 10,0 & 7,0 & 6,0 & 5,0 & 5,0 \\
\hline 3. & Відношення балансу державного бюджету до ВВП & $-2,2$ & $-3,1$ & $-2,5$ & $-2,3$ & $-2,1$ & $-2,0$ \\
\hline 4. & Відношення державного боргу до ВВП & 81,2 & 91,4 & 85,5 & 78,1 & 71,6 & 65,6 \\
\hline 5. & $\begin{array}{l}\text { Відношення сальдо поточного рахунку платіжного } \\
\text { балансу до ВВП }\end{array}$ & $-3,6$ & $-3,0$ & $-3,0$ & $-2,4$ & $-2,3$ & $-2,9$ \\
\hline 6. & Валові резерви (млрд дол. США) & 15,5 & 22,3 & 29,5 & 30,1 & 30,8 & 32,0 \\
\hline
\end{tabular}

Ажерело: [10].

- за типами платежів - погашення становитиме $57,4 \%$, обслуговування - 42,6\%;

- за валютами платежів - в украӥнській валюті $36,74 \%$, доларах 43,54\%, СП3 15,58\%, Євро 4,15 та інших валютах 0,18\% [6].

Проаналізувавши державний борг, можна зробити висновок, що в Україні відбувається нарощування як зовнішнього, так внутрішнього державного боргу, що пояснюється негативними процесами впливу внутрішніх і зовнішніх чинників на нього та неефективною борговою політикою в Україні.

Основними чинниками, що спричинили неефективну боргову політику уряду України, є: девальвація гривні (що призвело до збільшення боргу та вартості його обслуговування); падіння реального валового внутрішнього продукту; зниження внутрішнього споживчого попиту внаслідок інфляційних процесів та безробіття; негативний вплив реальної відсоткової ставки Національного банку України на боргову сферу та обмеження функціонування ринку позичкового капіталу.

Взаємозв'язок державних запозичень та рівнем безробіття виражається через співвідношення державного боргу до валового внутрішнього продукту, який виробляється в країні. Якщо темпи зростання державного боргу перевищують темпи зростання валового внутрішнього продукту, тоді відбувається спад економіки, що веде за собою скорочення робочих місць на ринку праці та призводить до зростання рівня безробіття в країні, що спостерігається сьогодні в Украӥні.

Крім цього, наявна низка бюджетних проблем: необхідність покриття дефіциту Пенсійного фонду, фінансування за рахунок державних запозичень державного бюджету, невиконання планів надходжень від приватизації державного майна, необхідність державної підтримки державних підприємств та банків [7].

Тенденція зростання частки гарантованого державою боргу вплинула на зниження рівня боргової безпеки країни. 3більшення частки державного боргу в іноземній валюті сприяє зростанню валютних витрат уряду 3 обслуговування боргових зобов'язань, створює загрозу подальшої девальвації гривні [7].

Основними причинами, які призвели до зростання державного і гарантованого державою боргу в Україні, $\epsilon:$

1) необхідність нарощування валютних резервів, які значно вичерпалися валютною інтервенцією Національного банку України;

2) залежність України від імпорту енергоносіїв;

3) технічна відсталість значної частини сфер національної економіки;

4) політична криза, анексія Автономної Республіки Крим та тривалий військовий конфлікт на сході краӥни;

5) використання державних запозичень для покриття дефіциту державного бюджету, зумовленого збільшенням видатків на оборону та обслуговування державного боргу, сформованого у попередні роки;

6) необхідність потужної державної підтримки державних підприємств та банків [8].

Серед проблем управління державного боргу України можна виділити:

— швидке зростання обсягів державного боргу;
- перевага зовнішньої заборгованості в структурі державного боргу, що несе в собі валютний ризик;

- великі розміри гарантованого державою боргу, що викликає додаткові витрати в зв'язку з неплатоспроможністю позичальників;

- значна заборгованість перед міжнародними фінансовими організаціями та органами управління іноземних держав, що породжує економічну небезпеку в країні;

- слабкий розвиток внутрішнього ринку державних цінних паперів, що ускладнює залучення державних позик;

- відсутність досконалого механізму активного управління державним боргом та ефективного використання залучених коштів [8].

Подальше зростання державного боргу Украӥни є дуже небезпечним і може призвести до втрати економічної незалежності, вилучення 3 фінансового ринку коштів, які б могли бути використані на розвиток реального сектору економіки, зменшення конкурентоспроможності на внутрішніх і зовнішніх ринках, спад рівня життя населення країни. А досягнення прогнозованого рівня загрожує Україні дефолт. Аля запобігання негативних наслідків необхідно удосконалити механізм управління державним боргом на інституціональному рівні, удосконалити нормативно-правову базу, а також підвищити рівень власного валового внутрішнього продукту шляхом модернізацї̈ вітчизняних підприємств [9].

Важливо відзначити, що наростання державного боргу України, тягне за собою зниження рівня боргової безпеки держави, що спричиняє негативні наслідки, такі як:

- зменшення валютних резервів та скорочення імпорту;

- зростання відсоткових ставок на ринку державних запозичень;

- зменшення виробничого споживання внаслідок падіння інвестицій;

- зниження міжнародного престижу країни та рівня життя населення та інші [8].

За даними показниками розвитку України, що визначені на 2018 рік Міністерством фінансів, очікується обсяг валового внутрішнього продукту на рівні 3,2 \% і прогнозується його подальше зростання. Відповідно, рівень державної заборгованості повинен зменшуватись, адже появляться кошти для обслуговування державного боргу і покращиться становище боргової політики країни (табл. 3).

Прогнозується, що до 2021 року, рівень державної заборгованості знизиться до рівня нижче $70 \%$ валового внутрішнього продукту при успішній і продуманій борговій політиці уряду України та зростанні темпів розвитку економіки країни.

На основі досліджень сучасного стану і тенденцій боргової політики України, можна зробити висновки:

- внаслідок проведення українським урядом політики, зорієнтованої на інфляційні механізми погашення дефіциту бюджету, загальна сума державного боргу постійно зростає; 
— особливістю державного боргу України є значне перевантаження у його структурі зовнішньої складової;

- на позичковому ринку простежується тенденція до збільшення строковості державних цінних паперів;

- спостерігається тенденція до збільшення обсягів фінансування програм розвитку, про що свідчить зростання частки гарантованого боргу внаслідок залучення кредитних ресурсів для будівництва та реконструкції автомобільних доріг, проте фінансування програм розвитку в реальному секторі економіки необхідно збільшувати.

Таким чином, оптимізація боргової політики України потребує розробки та впровадження цілісної стратегії, яка поєднуватиме завдання удосконалення нормативно-правового та інституційного забезпечення боргової політики, коротко- та середньострокові орієнтири управління державним боргом, інструменти радикального підвищення ефективності інвестиційної складової бюджетних видатків та стратегічні завдання переорієнтації боргової політики, зменшення боргового тягаря та розвитку альтернативних, непозичкових інструментів фінансування бюджетних видатків [9].

\section{ВИСНОВКИ}

У сучасній Україні повинна бути вироблена стратегій 3 питань залучення державних запозичень та управління ними на основі узгодження між собою бюджетної, валютної, грошво-кредитної, інвестиційної та податкової політики. В умовах загрозливого стану боргової безпеки першочерговим повинна бути розробка довгострокових планів залучення і управління державними запозиченнями, де мають міститися напрями залучення коштів та критерії ефективності їх використання.

Боргова політика України має пройти певні етапи удосконалення шляхом покращення нормативно-правової бази, розширення системи інструментів, завдань, пріоритетів скорочення боргів держави; реформування і реструктуризація економіки та фінансів; стабілізуючі дії уповноважених органів влади щодо макрофінансової стабілізації, що є актуальним сьогодні у життєдіяльності України.

Проведе дослідження показує, що сучасний стан боргової політики України є вкрай негативним, адже в умовах нестачі коштів держава не в змозі виконувати свої боргові зобов'язання, що веде за собою настання дефолту та підриву іміджу країни на світовому рівні.

Управління державним боргом потребує досконалого правового забезпечення щодо формування боргових зобов'язань, механізму їх управління, обслуговування і погашення в умовах, які склались в Україні на сучасному етапі. Уряду України необхідно реально вивчити картину обсягів державних запозичень, визначити критерії оцінки державного боргу, розробити механізм ефективного використання позичкових коштів та контролювати додержання оптимальної структури боргу, сумарного його обсягу і строків погашення.

\section{Мітература:}

1. Бюджетний кодекс України [Електронний ресурс]. - Режим доступу: http://zakon4.rada.gov.ua/laws/ show/2456-17

2. Артус М.М. Бюджетна система України: навчальний посібник / М.М. Артус. - Видавництво Европейського університету, 2005.

3. Аержавний борг України: механізм управління та обслуговування [Електронний ресурс]. - Режим доступу: http:// economyandsociety.in.ua/journal/8 ukr/ 118.pdf

4. Пояснювальна записка до проекту Закону України "Про державний бюджет України на 2018 рік". Інформація про соціально-економічне становище країни. / [Електронний ресурс]. - Режим доступу:www.search.ligazakon.ua/1_doc2.nsf/link1/GH5EG00A
5. Офіційний сайт Аержавної служби статистики України [Електронний ресурс]. - Режим доступу: http:/ /ukrstat.gov.ua

6. Офіційний сайт Міністерства фінансів України [Електронний ресурс]. - Режим доступу: hppt:// www.minfin.gov.ua

7. Сальникова Т.В. Аержавний борг України: оцінка та напрями підвищення ефективності управління [Електронний ресурс]. - Режим доступу: www.oaji.net/ articles/2017/1900-152546353.pdf

8. Сокирко О.С. Аналіз сучасного стану державного боргу України / О.С.Сокирко. - Східна Європа: Економіка, Бізнес та Управління. - Випуск 6 (11) 2017 [Електронний ресурс]. - Режим доступу: http:// ir.nusta.edu.ua/jspui/ handle/123456789/2488

9. Аем'янчук М.А., Коба О.С. Аослідження впливу державного боргу і дефіциту бюджету на національну економіку// Фінансові аспекти розвитку держави, регіону та суб'єктів господарювання: сучасний стан та перспективи. - Одеса, 2016.

10. Омеляненко М.О. Модернізація політики управління державним боргом України [Електронний ресурс]. - Режим доступу: http://www.investplan.com.ua/ ?op $=1 \& \mathrm{z}=5867 \& \dot{\mathrm{i}}=8$

11. Slav'yuk R. GOVERNMENT DEBT MANAGEMENT: CHALLENGES AND PERSPECTIVES / R. Slav'yuk, N. Slaviuk // Investment Management and Financial Innovations. - 2018. - No. 15. Issue 3. - P. 143-156.

\section{References:}

1. Verkhovna Rada of Ukraine (2010), "The Budget Code of Ukraine", available at: http://zakon4.rada.gov.ua/laws/ show/2456-17 (Accessed 30 Sept 2018).

2. Artus, M.M. (2005), Biudzhetna systema Ukrainy [Budget system of Ukraine], European University Publishing House, Kyiv, Ukraine.

3. Shelest, O.L. (2017), "The state debt of Ukraine: the mechanism of management and service", available at: http:/ /economyandsociety.in.ua/journal/8ukr/118.pdf (Accessed 30 Sept 2018).

4. Verkhovna Rada of Ukraine (2018), "Explanatory note to the draft Law of Ukraine "On the State Budget of Ukraine for 2018", available at: www.search.ligazakon.ua/ 1 doc2.nsf/link1/GH5EG00A (Accessed 30 Sept 2018).

5. Official site of the State Statistics Service of Ukraine (2018), available at: http://ukrstat.gov.ua (Accessed 30 Sept 2018).

6. Official website of the Ministry of Finance of Ukraine (2018), available at: hppt://www.minfin.gov.ua (Accessed 30 Sept 2018).

7. Salnikova, T.V. (2017), "State Debt of Ukraine: Assessment and Directions for Improving Management Effectiveness", available at: www.oaji.net/articles/2017/ 1900-152546353.pdf (Accessed 30 Sept 2018).

8. Sokirko, O.S. (2017), "Analysis of the Current State of State Debt of Ukraine", Eastern Europe: Economics, Business and Management, vol. 6 (11), available at: http:/ ir.nusta.edu.ua/jspui/handle/123456789/2488 (Accessed 30 Sept 2018).

9. Demyanchuk, M.A. and Koba, O.S. (2016), "Investigation of the impact of public debt and budget deficit on the national economy", [Financial aspects of development of the state, region and business entities: the current state and prospects. Collection of scientific works], Odessa, Ukraine.

10. Omelyanenko, M.O. (2018), "The modernization of Ukraine's public debt management policy", available at: http://www.investplan.com.ua/?o $p=1 \& \mathrm{z}=5867 \& \mathrm{i}=8$ (Accessed 30 Sept 2018).

11. Slav'yuk, R. and Slaviuk, N. (2018), "Government debt management: challenges and perspectives", Investment Management and Financial Innovations, vol. 15, no. 3, pp. 143-156.

Стаття надійшла до редакиї 25.10.2018 p. 
УАK 338.2:352

Т.Ф. Куиенко,

к.е. н., дочент, дочент кафедри начіональної економіки та публічного управління,

АВНЗ "Кӥ̈ський начіональний економічний університет імені Вадима Гетьмана", м. Київ

A. O. Сабадош,

к.е.н., дочент, дочент кафедри начіональної економіки та публічного управліннл,

АВНЗ "Київсъий начіональний економічний університет імені Вадима Гетьмана", м. Київ

DOI: $10.32702 / 2306-6806.2018 .11 .50$

\title{
БАЗОВІ СКАААОВІ ЕФЕКТИВНОГО

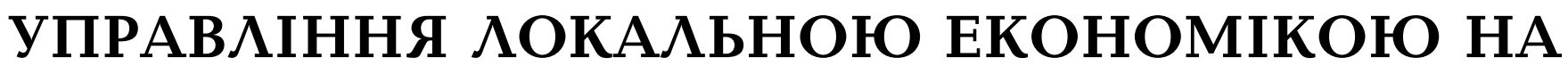 "КРИХКИХ" ТЕРИТОРІЯХ В УМОВАХ КОНФЛІКТУ В УКРАЇНI
}

\author{
T. Kutsenko, \\ Candidate of Economic Sciences, Docent, Docent of National Economics and Public Administration Department, \\ SHEI "Kyiv National Economic University named after Vadym Hetman", Kyiv \\ A. Sabadosh, \\ Candidate of Economic Sciences, Docent, Docent of National Economics and Public Administration Department, \\ SHEI "Kyiv National Economic University named after Vadym Hetman", Kyiv
}

\section{BASIC ELEMENTS OF EFFECTIVE MANAGEMENT OF LOCAL ECONOMY ON "FRAGILE" TERRITORIES UNDER CONFLICT CONDITIONS IN UKRAINE}

У Статті розгАЯАються базові СКАадові управАіння Аокальною економікою на "крихких" територіях в умовах конфлікту та започаткованих реформ в Україні з точки зору реалізації подальших кроків, завдяки яким можуть бути здійснені майбутні реальні перетворення в цій сфері. Акцентується увага на тому, що задля Сприяння соціально-економічному відновленню муніципальних економік, стабілізації уражених кризою територій та ї зміцнення, задля Створення необхідних умов для повернення та реінтеграціі переміщених осіб, по-перше: "золотим кАючиком" ефективного управління Аокальною економікою конкретної громади на конкретній "крихкій" території має стати доброчесне адміністрування організації всіх процесів на локальному рівні з урахуванням саме тих чинників, викликів та загроз, що притаманні цій території. По-друге, потребує ефективного налагодження взаємодія всіх суб'єктів, що несуть відповідальність за результати прийняття та реалізації публічних управлінських рішень з обов'язковим впровадженням Системної оцінки ї ефективності на основі використання методики КРІ (Кеу Регformanсе Indicators - кАючові показники результативності). По-третє, продуктивна діяльність територіальних громад щодо соціально-економічного відновлення та подальшого розвитку "крихких" територій має бути вмотивована головним чином потребою в зміцненні єАності країни, здоровим прагматизмом та економічним Патріотизмом з акцентом не на локальних містечкових інтересах, а на соціально-економічному розвитку громади в контексті розбудови національної економіки України та збереження їі цілісності.

НаголошуєтьСя також що дяя того, щоб забезпечити ефективне управління Аокальною економікою на "крихких" територіях потрібні спеціалісти, яких в Україні бракує, томує очевидним, що державі варто було б приділити увагу підготовці фахівців саме такого напряму, які б були здатні реалізовувати поСтавАені завдання в умовах конфлікту та гібридних загроз, що єнині кАючовою передумовою, яка у перспективі зможе принести реальні результати.

The article presents basic elements of local economy management on "fragile" territories under conflict conditions and within initiated reforms in Ukraine with the perspective of implementation of further steps, due to which future real transformations in this field can be made. It is emphasized that in order to promote socioeconomic restoration of municipal economies, stabilization of the areas affected by crisis and their strengthening, in order to create necessary conditions for the return and reintegration of displaced people, firstly: the "golden key" of effective management of local economy of a particular community at the specific "fragile"territory should become the honest administration of organization of all processes on local level, considering namely those factors, challenges and threats that are distinctive for this territory. Secondly, it is required effective adjustment of the 
interaction of all entities responsible for results of the adoption and implementation of public administrative decisions with mandatory introduction of systemic evaluation of their efficiency based on usage of KPI techniques (Key Performance Indicators). Thirdly, productive activity of the territorial communities regarding socio-economic recovery and further development of "fragile" territories should be motivated mainly by the need to strengthen the unity of the country, by healthy pragmatism and economic patriotism with an emphasis not on local provincial interests, but on socio-economic development of the community in the context of growth of the national economy of Ukraine and preserving its integrity. It is also noted that in order to ensure effective management of local economy on "fragile" areas we need specialists, who are lacking in Ukraine, that is why it is obvious that the state should pay attention to training the experts is such field, who would be able to complete the given tasks in the conditions of conflict and hybrid threats, which is now the key precondition that in the future will be able to bring real results.

Ключові слова: "крихкі територіі" ; складові управління локальною економікою; начіональна політика держави; інституиіино-комунікативний блок локального управління; доброчесне адміністрування; продуктивна діяльність територіальних громад; очінювання управління за чілями та результатами; коригування чілей, пріоритетів та акщентів; моніторинг реалізачії управлінських рішень.

Key words: "fragile" territories, elements of local economy management, national policy, institutional and communicational contents of local management, bonest administration, productive activity of territorial communities, objective - and result-based management evaluation, adjusting of goals, priorities and accents, monitoring of implementation of administrative decisions.

\section{ПОСТАНОВКА ПРОБЛЕМИ}

Важливість розгляду обраної теми базується на тому, що у 2014-2018 роках в Україні було зроблено ряд дуже важливих кроків щодо оцінки та пошуку ефективних механізмів соціально-економічного відновлення "крихких" територій в умовах конфлікту. Насамперед, у березні 2015 року був опублікований Звіт щодо оцінки шляхів відновлення та розбудови миру в Східній Україні, що проводилася спільними зусиллями Европейського Союзу, Організації Об'єАнаних Націй та Групи світового банку під керівництвом та за участі Уряду України) [1].

Окрім того, одне 3 перших наукових комплексних досліджень, що здійснене також у 2015 році з позицій національної безпеки України, та вартує особливої уваги, належить вченим Національного інституту стратегічних досліджень) [2]. У ньому були визначені умови реінтеграції та пріоритети відновлення Аонбасу, окреслені шляхи подолання соціальних наслідків збройної агресії Росії проти України, розроблені прогнози розвитку подій на Аонбасі та довкола Криму, а також сценарії майбутнього України в глобалізованому світі.

\section{АНАЛІЗ ОСТАННІХ ДОСЛІДЖЕНЬ І ПУБЛІКАЦІЙ}

Кількість наукових публікацій, присвячених різним аспектам проблематики війни на Аонбасі та анексії Криму, в тому числі проблемам соціально-економічного відновлення "крихких" територій, постійно зростає та представлена в доробку науковців та практиків, серед яких: Балуєва О.В., Бобро А.Г., Келембет О.С., Хвесик М.А., Голян В.А., Новіков В.М., Полчанов А.Ю. та ряд ін.

Таблиця 1. Оцінка сукупних потреб у відновленні (млн дол. США)

\begin{tabular}{|c|c|c|c|}
\hline Компонент відновлення & $\begin{array}{l}\text { млн дол. } \\
\text { США }\end{array}$ & Компонент відновлення & $\begin{array}{c}\text { млн дол. } \\
\text { США }\end{array}$ \\
\hline $\begin{array}{l}\text { Інфраструктура та соціальні } \\
\text { послуги }\end{array}$ & 1257,7 & Економічне відновлення & 135,5 \\
\hline Охорона здоров'я & 184,2 & Зайнятість & 40,0 \\
\hline Освіта & 9,7 & Продуктивні сили та засоби існування & 33,0 \\
\hline Соціальна допомога & 329,4 & Економічне планування на місцевому рівні & 7,5 \\
\hline Енергетика & 78,9 & МСП та приватний сектор & 30,0 \\
\hline Транспорт & 558,2 & Фінансові послуги & 25,0 \\
\hline Водопостачання та водовідведення & 40,1 & \multirow[t]{3}{*}{ Соціальна стійкість, розбудова миру } & \multirow[t]{3}{*}{126,8} \\
\hline Довкілля & 30,0 & & \\
\hline Громадські будівлі та житло & 27,2 & & \\
\hline & \multicolumn{3}{|c|}{ Разом 1520,0} \\
\hline
\end{tabular}

Однак варто наголосити, надактуальною залишається проблема пошуку інструментів ефективного управління локальною економікою на "крихких" територіях в умовах конфлікту в Україні. Метою статті є розглянути базові його складові та інструментарій, завдяки якому можуть бути здійснені майбутні реальні перетворення в цій сфері з урахуванням міжнародного досвіду, зважаючи на значні ризики та виклики, що мають місце донині в сучасних умовах.

\section{ВИКЛАД ОСНОВНОГО МАТЕРІАЛУ ДОСЛІДЖЕННЯ}

Очевидно, що гібридна війна принесла нашій країні не тільки військову агресію, а й значні втрати та руйнування локальних економік, насамперед, у районах $\Lambda$ уганської та Аонецької областей, підконтрольних українській владі. Хоча фахівці наголошують, що конфлікт 2014 року розпочався тоді, коли економіка Аонбасу вже прийшла в занепад через тривалу системну неефективність та інституційні вади, тому загальні потреби за компонентом економічного відновлення оцінюються на рівні 135,5 млн дол. США (див. табл. 1) [1-3].

Зрозуміло, що постраждалі від конфлікту території Аонецької та $А$ уанської областей, а також Запорізької, Аніпропетровської та Харківської областей, розвиток яких зазнав негативного впливу внаслідок збройного конфлікту на сході країни, залишаються в категорії "крихких", тому що конфлікт продовжується. Однак "крихкими", на наш погляд, слід вважати також території, громади яких прийняли та продовжують приймати сім'ї переселенців, так званих внутрішньо переміщених осіб (ВПО), а також громади тих областей, які знаходяться в зоні серйозних ризиків та геополітичних викликів в інших частинах країни. За таких умов, з урахуванням ще не обрахованих, однак очевидних соціально-економічних наслідків та досі непередбачуваних гібридних загроз як внутрішніх, так і зовнішніх конфліктів, саме перед Урядом та громадами "крихких" територій стоїть непросте завдання налагодження ефективного управління соціально-економічни- 
ми процесами на локальному рівні, вирішення якого дається дуже важко, зважаючи на різного роду чинники, що активуються в останні роки.

В умовах конфлікту та започаткованих Урядом реформ одним із головних пріоритетів реформи децентралізації управління є підвищення спроможності територіальних громад на всій території України. Однак щодо саме локальних економік "крихких" територій, варто зробити акценти на цілях, залля яких потрібна ця спроможність, а саме задля: пожвавлення економічної активності громади та забезпечення соціально-економічного відновлення; протистояння гібридним загрозам та ризикам в соціально-економічній сфері; врегулювання конфліктів тощо. Тому спроможність територіальних громад "крихких" територій вартує розглядати, виокремлюючи її складові, а саме: інституційну; комунікативну; адміністративну; економічну; соціальну; фінансову та ін.

Як констатують експерти, соціально-економічне відновлення "крихких" територій, насамперед, Аонбасу вже розпочалося й нині вже одержані перші результати щодо підвищення спроможності їх громад. Варто акцентувати, що саме створені ОТГ взяли на себе відповідальність в цих складних умовах за реалізацію поставлених завдань (на 10.04.2018 року з 728 ОТГ у Аонецькій обл. створено 15, в Муганській - 12) [4]. Проте складність завдань в умовах конфлікту, зокрема в соціально-економічній сфері, перевершила очікування позитивних зрушень та результатів не тільки на Аонбасі, але й загалом в усій Україні.

Відповідно, вивчивши досвід країн, що мали подібні проблеми в умовах конфлікту, слід розробити та запропонувати конкретні механізми налагодження ефективного управління локальною економікою (локальна/ муніципальна/місцева економіка - терміни-синоніми). Однак, насамперед, вартує усвідомити базові його складові та взаємозв'язок між ними, на основі чого збагнути алгоритм тих кроків, завдяки яким можуть бути здійснені подальші реальні перетворення в практиці господарювання на локальному рівні (див. рис. 1).

1. Національна політика держави має бути спрямована на визначення перспектив розвитку муніципальних економік "крихких" територій в умовах конфлікту на основі результатів оцінювання загроз та визначених державою стандартів, на розбудову обгрунтованої системи стимулів (бюджетно-податкових, інноваційно-інвестиційних, публічно-приватного партнерства (державно-приватного та муніципально-приватного), міжнародного співробітництва та інших) Аля здійснення позитивних зрушень, та в разі успішності, на сприяння соціально-економічному відновленню муніципальних економік, стабілізації уражених кризою територій та їх зміцнення, задля створення необхідних умов для повернення та реінтеграції переміщених осіб тощо. У великій мірі це вже висвітлено в державних нормативно-правових документах, зокрема в Аержавній цільовій програмі відновлення та розбудови миру в східних регіонах України на $2017-2020$ pp.

Зміст цих складових розкривається наступним чином:

2.Інституційно-комунікативний блок управління локальною економікою має включати наступні аспекти: управління формуванням громадянських компетентностей; управління комунікаціями; управління соціальноекономічними конфліктами та ін.
Управління формуванням громадянських компетентностей має бути спрямоване на формування свідомого, активного громадянина, здатного жити та діяти у громадянському суспільстві, що постійно оновлюється і розвивається. Аосвід ряду зарубіжних країн свідчить, що тільки через розвиток громадянських компетентностей можливо реалізувати принципи Good Governance (економного/результативного/кращого врядування) та посилити місцеве самоврядування. В умовах конфлікту, на наш погляд, акцент на громадянські компетентності (лідерство та відповідальність; комунікативність та інноваційність; патріотизм, активну життєву позицію та ефективність рішень (фаховість); самоорганізацію та саморозвиток; мультикультурність та демократичність) $€$ надактуальним.

Управління комунікаціями має бути спрямоване на зниження вразливості верств населення, що зазнало впливу конфлікту, та зміцнення соціальної стійкості, відновлення довіри до держаних, місцевих органів влади та інших інституцій суспільства та співпраці 3 ними, а також на формування комунікацій між всіма частинами України, враховуючи, що впливи, потреби та можливості змінюватимуться та розвиватимуться з плином часу.

Управління соціально-економічними конфліктами має бути спрямоване на погашення конфліктних ситуацій, оцінювання ризиків їх відновлення з метою упередження нових конфліктів в соціально-економічній сфері, зокрема пов'язаних зі зростанням напруженості між державними інституціями та громадами, між внутрішньо переміщеними особами (ВПО) та приймаючими іх громадами (збільшення чисельності та зростання тривалості перебування переміщених осіб справляють значний тиск на місцеві ресурси, на надання послуг та систему врядування тощо) і т.А., що ставить під загрозу інвестиції в об'єкти інфраструктури, надання послуг та економічне відновлення загалом.

3. Аобречесне адміністрування на місцевому рівні та прийняття рішень в умовах гібридних загроз має бути спрямоване на врахування особливостей адміністрування на "крихких" територіях та прийняття ефективних

Складові управління локальною економікою на «крихких» територіях

\begin{tabular}{|c|c|c|}
\hline $\begin{array}{l}6 . \\
\mathrm{M} \\
\mathrm{O} \\
\mathrm{H} \\
\mathrm{I}\end{array}$ & 1. & \begin{tabular}{|l} 
Національна політика держави: \\
$\quad \checkmark$ цілі/стратегія/оцінювання загроз; \\
$\checkmark$ \\
$\quad$ стандарти; \\
$\quad$ регуляторний інструментарій
\end{tabular} \\
\hline $\begin{array}{l}\text { T } \\
\mathrm{O} \\
\mathrm{P} \\
\mathrm{U} \\
\mathrm{H} \\
\Gamma\end{array}$ & 2. & $\begin{array}{l}\text { Iнституційно-комунікативний блок управління: } \\
\quad \checkmark \text { управління формуванням громадянських компетентностей; } \\
\checkmark \checkmark \text { управління комунікаціями; } \\
\checkmark \checkmark \text { управління соціально-економічними конфліктами }\end{array}$ \\
\hline $\begin{array}{l}\text { P } \\
\text { E } \\
\text { А } \\
\text { Л }\end{array}$ & 3. & $\begin{array}{l}\text { Доброчесне адміністрування - алгоритм дій по організації всіх } \\
\text { процесів на локальному рівні на основі соціальної } \\
\text { відповідальності державних службовців }\end{array}$ \\
\hline $\begin{array}{l}1 \\
3 \\
\mathrm{~A} \\
\mathrm{~L} \\
\mathrm{I} \\
\mathrm{I} \\
\mathrm{I} \\
\mathrm{y} \\
\mathrm{\Pi} \\
\mathrm{P}\end{array}$ & 4. & $\begin{array}{l}\text { Продуктивна діяльність територіальних громад } \\
\text { за напрямами: } \\
\quad \checkmark \text { економічним; } \\
\quad \checkmark \text { соціальним; } \\
\quad \checkmark \text { фінансовим. } \\
+ \text { Публічно-приватне партнерство. } \\
+ \text { Міжнародне співробітництво }\end{array}$ \\
\hline $\begin{array}{l}\mathrm{P} \\
\mathrm{I}\end{array}$ & 5. & Оцінювання управління за цілями та результатами \\
\hline $\begin{array}{l}\mathrm{U} \\
\mathrm{E} \\
\mathrm{H} \\
\mathrm{b}\end{array}$ & 7. & Корегування цілей, пріоритетів, акцентів \\
\hline
\end{tabular}

Рис. 1. Взаємозв'язок між складовими управління локальною економікою на "крихких" територіях 
рішень в умовах конфлікту та гібридних загроз. $Є$ очевидним, що мало сформулювати цілі. Необхідно прокласти через адміністрування чіткий ефективний шлях реалізації завдання. На етапі прийняття кожного управлінського рішення мають прогнозуватися та обгрунтовуватися наслідки, що дасть змогу не фінансувати заздалегідь провальні та неефективні управлінські дії. В даному контексті актуальною $є$ модель "адміністративної ефективності" Вудро Вільсона, в основі якої використання в публічному адмініструванні методів організації та управління з бізнесу, якіє раціональними, ефективними та дієвими. Але це можливо тільки за умов високого професіоналізму в системі публічного адміністрування, тобто підбору публічних службовців за їхньою професійною компетентністю [5].

Варто наголосити, що адміністрування має бути доброчесним, тому що за інших умов прекрасні ідеї можуть бути спаплюжені, гроші розкрадені чи розпорошені, а результати - ніякими або фіктивними, тобто далекими від реальних очікувань людей. Саме соціальна відповідальність в поєднанні з професіоналізмом державних службовців перетворять іх на рушійні сили реальних соціально-економічних перетворень в Україні.

4. Продуктивна діяльність територіальних громад щодо соціально-економічного відновлення та подальшого розвитку "крихких" територій має бути вмотивована головним чином, на наш погляд, потребою в зміцненні єдності країни, здоровим прагматизмом та економічним патріотизмом з акцентом не на локальних містечкових інтересах, а на соціально-економічному розвитку громади в контексті розбудови національної економіки України та збереження їі цілісності.

Економічні аспекти продуктивної діяльності громад на "крихких" територіях мають бути спрямовані насамперед, на пожвавлення економічної активності їх мешканців, на відновлення муніципальних економік, на підвищення їх спроможності та можливостей економічної реінтеграції; соціальні аспекти - на відновлення та зміцнення соціальної інфраструктури, зміцнення добробуту переміщених груп населення та приймаючих громад, поліпшення соціального захисту груп населення, що зазнали впливу конфлікту, надання критично важливих соціальних послуг тощо; фінансові аспекти на збільшення ресурсної бази місцевих бюджетів завдяки розширенню джерел надходжень; на позбавлення "крихкої" території статусу своєрідної "офшорної зони"; на виконання фінансових зобов'язань соціального спрямування; на фінансове забезпечення відновлення інфраструктури тощо із залученням різноманітних інструментів державного, грантового, інвестиційного та проектного походження, іноземних інвестицій для фінансування проектів відновлення тощо.

Загалом всі ці аспекти продуктивної діяльності громад на "крихких" територіях почали обговорюватися та висвітлюватися в різних джерелах експертними групами чи окремими авторами, є цікавими та слушними, навіть окремі проекти активно реалізуються як точкові реформи 3 залученням бюджетних чи міжнародних джерел допомоги. Однак загалом дослідження та досвід їх впровадження $€$ розрізненими та фрагментарними, тому вважаємо за потрібне акцентувати увагу на необхідності систематизації такого роду напрацювань та підтримуємо створення Науково-консультативної ради при Міністерстві з питань тимчасово окупованих територій та внутрішньо переміщених осіб України з метою формування єдиної науково-практичної платформи, де випрацьовувалися б базові алгоритми дій з чіткими виконавцями, кінцевими результатами, часовим виміром та індикаторами вимірювання результатів для вирішення конкретних проблем "крихких" територій, зокрема й у сфері управління локальними економіками.

5. Оцінювання управління за цілями та результатами має здійснюватись на основі системного використання програмно-цільового підходу та вдосконалення си- стеми звітності, що вже започатковується в Україні на рівні місцевих бюджетів й дасть змогу в подальшому в процесі оцінювання ефективності перенести акцент 3 витрат і ресурсів на наслідки й результати. Зокрема оцінювання ефективності діяльності підрозділів публічних органів має грунтуватися на співвідношенні якості послуг, які вони надають, і витрат, які вони при цьому зазнають.

Варто зазначити, що найбільші проблеми пов'язані 3 розробкою показників, що дають змогу оцінити зростання ефективності роботи публічної адміністрації в умовах конфлікту. Загалом відомо, що при цьому можна використовувати різноманітні методи. Наприклад, у мирному часі у Аанії, Португалії й Туреччині вивчається суспільна думка про якість державних послуг, в Австралії проводиться оцінне дослідження щодо виконання програм. У Великобританії будь-яка ініціатива з удосконалювання державного управління оцінюється за спеціальною методикою, де ефективність вимірюється не витраченими зусиллями, а досягнутими результатами [6]. В українських реаліях слід враховувати специфіку "крихких" місцевих економік та пропонувати окрім стандартного набору показників ще й додатковий, специфічний, що буде власне адекватним ступеню "крихкості" території, умовам, викликам та ризикам.

6. Моніторинг реалізації управлінських рішень на рівні локальної економіки має здійснюватися через впровадження системної оцінки ефективності публічних управлінських рішень, яка реалізується через вимірювання ефективності, результативності, задоволеності потреб індивіда, якості та наслідків.

Одним з ключових механізмів реформування публічної служби на локальному рівні є інтеграція сучасних методів оцінки професійної діяльності публічних службовців, від якої залежить кінцевий сукупний результат роботи органу публічної влади. Вважаємо розробку та запровадження окремих показників результативності діяльності публічних службовців на основі використання принципів методики КPI (Key Performance Indicators - Ключові показники результативності) [7; 8] оптимістичним моментом у проведенні моніторингу ефективності реалізації управлінських рішень на рівні локальної економіки.

7. Корегування цілей, пріоритетів, акцентів управління - обов'язкова управлінська складова, від якої залежить технологічно та технічно вчасність та виваженість подальших змін в національній політиці держави.

Всі названі вище складові управління локальною економікою $є$ об'єктивно необхідними в умовах конфлікту і мають здійснюватись як на управлінському рівні власне громад, так і на рівні держави, зокрема бути в компетенції Міністерства з питань тимчасово окупованих територій та внутрішньо переміщених осіб України. Ними не варто нехтувати, а навпаки спробувати налагодити ці процеси швидко та ефективно.

Слід наголосити, що центральною складовою, яка може стати саме тим "золотим ключиком" ефективного управління локальною економікою конкретної громади на конкретній "крихкій" території, на наш погляд, є алгоритм доброчесного адміністрування дій по організації всіх процесів на локальному рівні з урахуванням саме тих чинників, викликів та загроз, що притаманні цій території.

Аосвід всіх розвинутих країн свідчить, що ефективна публічна адміністрація є надбанням зрілого громадянського суспільства, саме активність якого й стала каталізатором реформування системи публічного управління та адміністрування. Проте неможливо знайти підтвердження у світовому досвіді наявності високого рівня розвитку національної економіки при неефективній та непрофесійній публічній адміністрації.

Простежується взаємозв'язок між зрілістю громадянського суспільства, ефективністю публічних адмі- 
ністрацій та розвитком локальних економік (див. рис. 2).

Більш того, особливий акцент ставиться на ефективності всієї системи публічної адміністрації. Публічний службовець не має права на неефективну діяльність. Наслідки помилкових управлінських рішень мають дуже негативний вплив на якість життя громадянина і суспільства загалом, особливо в умовах конфлікту.

\section{ВИСНОВКИ}

Реалізація Аержавної цільової програми відновлення та розбудови миру в східних регіонах України на 2017-2020 рр. в умовах конфлікту, що продовжується, може бути результативною: по-перше, за умов формування ефективного місцевого самоврядування на "крихких територіях", насамперед, на найнижчому його рівні, тобто на рівні ОТГ, які нині активно створюються; по-друге, при наявності ефективно діючих всіх складових управління локальною економікою територіальних громад, при чому взаємодія суб'єктів, що несуть відповідальність за результати прийняття та реалізації управлінських рішень, також має бути ефективно налагоджена; по-третє, "золотим ключиком", що створюватиме мотивації щодо зміцнення єдності країни, здорового прагматизму та економічного патріотизму з акцентом не на локальних містечкових інтересах, а на соціально-економічному розвитку громади в контексті розбудови національної економіки України та збереження iii цілісності, має стати доброчесне адміністрування дій по організації всіх процесів на локальному рівні з урахуванням саме тих чинників, викликів та загроз, що притаманні кожній конкретній території.

Насамкінець, слід наголосити: для того, щоб забезпечити ефективне управління локальною економікою на "крихких" територіях, зрозуміло, потрібні спеціалісти, яких, на наш погляд, в Україні бракує. Названа проблема $є$ зовсім не вивченою та може бути досить перспективною для подальших досліджень. Водночас $є$ очевидним, що державі варто було б приділити увагу підготовці фахівців саме такого напрямку, які б були здатні реалізовувати поставлені завдання в умовах конфлікту та гібридних загроз, що, на наш погляд, є нині ключовою передумовою, яка у перспективі зможе принести реальні результати омріяного "економічного дива для людей".

Мітература:

1. Україна. Оцінка відновлення та розбудови миру. Аналіз впливу кризи та потреб на Східній Україні. Том 1. Зведений звіт ЄС, ООН та Групи Світового Банку. Березень, 2015. [Електронний ресурс]. - Режим доступу: // http://www.un.org.ua/images/RPA_V1_Ukr.pdf

2. Аонбас і Крим: ціна повернення: монографія / За заг. ред. В.П. Горбуліна, О.С. Власюка, Е.М. Цібанової, О. М. Аяшенко. - К. : НICA, 2015. - 474 с. [Електронний ресурс]. - Режим доступу: http://www.niss.gov.ua

3. Панькова О.В. Концептуальні підходи до соціальної політики України за умов нестабільності / O.В. Панькова [Електронний ресурс]. - Режим доступу: http:// konceptualni_pidkhodi do_socialnoji_politiki_ukrajini_ za_umov nestabilnosti $\overline{5}-1-0-30$

4. Мӧніторинг процесу децентралізації влади та реформування місцевого самоврядування станом на 10 квітня 2018 року [Електронний ресурс]. - Режим доступу: http://www.minregion.gov.ua/decentralization/

5. Wilson W. The Study of Administration/W. Wilson// Political Science Quarterly. - 1997. — № 2. - P. 481-506.

6. Мельтюхова Н.М. Зарубіжний досвід публічного адміністрування: метод. рек. / Авт. кол.: Н.М. Мельтюхова, В.В. Корженко, Ю.В. Аідок та ін.; за заг. ред. Н.М. Мельтюхової. - К.: НААУ, 2010. - 28 с. - С. 19.

7. Наказ "Про затвердження Методичних рекомендацій щодо визначення ключових показників результа-

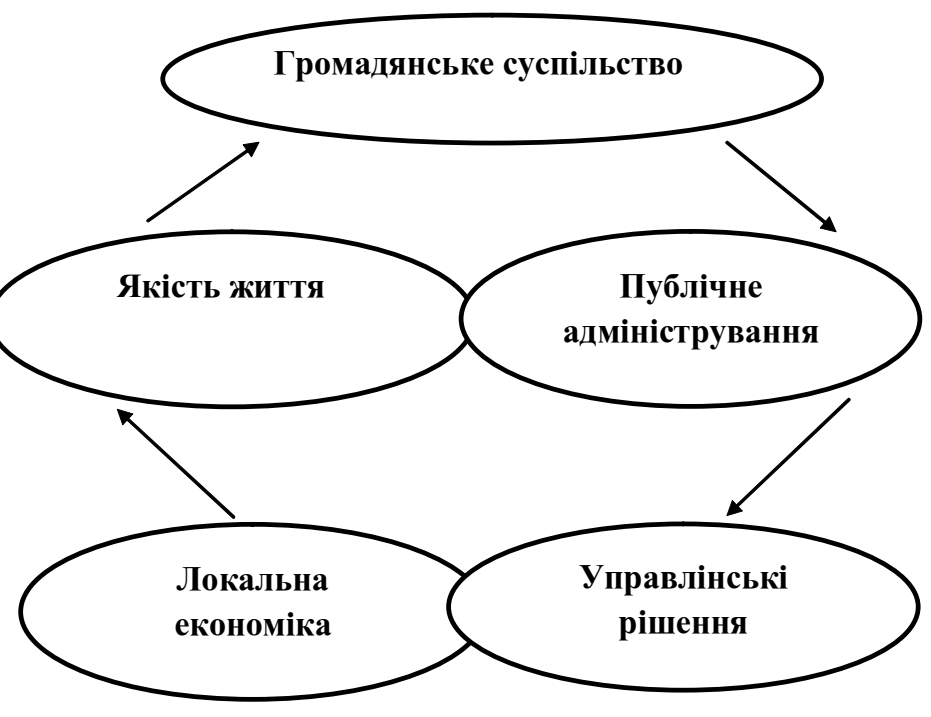

ис. 2. Взаємовплив громадянського суспільства, публічного адміністрування та розвитку локальної економіки

тивності, ефективності та якості службової діяльності державних службовців" [Електронний ресурс]// Національне Агентство України з питань державної служби. - 2017. - Режим доступу: http://nads.gov.ua/sites/ default/files/imce/2371.pdf

8. Саєнко О. Оцінити результат, а не процес: нова система КPI для держслужбовців [Електронний ресурс] / Oлексанар Саєнко // Українська правда. - 2018. Режим доступу до ресурсу: https://www.pravda.com.ua/ columns/2018/03/29/7176129/

\section{References:}

1. UN, EU and World bank (2015), "Ukraine. Assessment of the restoration and development of peace. Analysis of the impact of the crisis and needs in Eastern Ukraine. Volume 1.Summary report", available at: http:// www.un.org.ua/images/RPA_V1_Ukr.pdf (Accessed 15 Oct 2018).

2. Horbulin, V.P. Vlasiuk, O.S. Libanova, E.M. and Liashenko O.M.(2015), Donbas i Krym: tsina povernennia [Donbass and Crimea: the price of return], NISD, Kyiv, Ukraine.

3. Pan'kova, O.V. (2013), "Conceptual approaches to the social policy of Ukraine in conditions of instability", available at: http://konceptualni_pidkhodi_do_socialnoji_politiki ukrajini za_umov_n̄estabilnosti/5-1-0-30 (Accessed 15 Oct 2018).

4. Ministry for Regional Development, Building and Housing of Ukraine (2018), "Monitoring the process of decentralization of power and reform of local selfgovernment as of April 10, 2018", available at: http:// Www.minregion.gov.ua/ decentralization/ (Accessed 15 Oct 2018).

5. Wilson, W. (1997), "The Study of Administration", Political Science Quarterly, vol. 2, pp. 481-506.

6. Mel'tiukhova, N.M. Korzhenko, V.V. Didok, Yu.V. (2010), Zarubizhnyj dosvid publichnoho administruvannia [Foreign experience of public administration], NADU, Kyiv, Ukraine.

7. National Agency of Ukraine on Civil Service (2017), "Order "On Approval of Methodological Recommendations on the Determination of Key Indicators of Effectiveness, Efficiency and Quality of Civil Servants' Activities"", available at: http://nads.gov.ua/sites/default/files/imce/ 2371.pdf (Accessed 15 Oct 2018).

8. Saienko, O. (2018), "Evaluate the result, not the process: a new CRI system for civil servants", Ukrains'ka pravda, available at: https://www.pravda.com.ua/ columns/ 2018/03/29/7176129/ (Accessed 15 Oct 2018).

Стаття надійшла до редакиії 29.10.2018 р. 
3. A. Мaиyк,

к.е.н., доцент, дочент кафедри фінансів,

Івано-Франківський начіональний технічний університет нафти і газу, м. Івано-Франківськ

\title{
ОЦІНКА РЕГІОНААЬНОГО РОЗПОАІАУ ФІНАНСОВИХ ПОСАУГ ІНСТИТУТІВ СПIЛЬНОГО ІНВЕСТУВАННЯ В УКРАЇНI
}

\author{
Z. Matsuk, \\ PhD, Associate Professor, Department of Finance, \\ Ivano-Frankivsk national technical university of oil and gas, Ivano-Frankivsk
}

\section{EVALUATION OF THE REGIONAL DISTRIBUTION OF THE COLLECTIVE INVESTMENT FUNDS' FINANCIAL SERVICES IN UKRAINE}

Мета. На основі проведеного аналізу оцінено стан охоплення населення країни та областей фінансовими послугами інститутів спільного інвестування.

Методи дослідження. У Статті використано методи аналізу та синтезу, графічні методидослідження, економіко-статистичні методи збору та обробки інформації, зокрема вибіркові, дослідження, групування, статистичні порівняння величин, трендовий аналіз, коефіцієнтний та відносних величин - у процесі оцінювання стану охоплення населення країни та областей фінансовими посл угами інститутів спільного інвестування, а також логічного узагальнення - при формулюванні висновків.

Отримані результати. Оцінено стан охоплення населення України фінансовими послугами інститутів Спільного інвестування (ICI) протягом 2009-2017 рр. за допомогою сукупного індексу охоплення (розраховано на основі наступних СКладових: за чисельністю населення, за обсягом активів, за обсягом вкАадень фізичних осіб в ІСІ та за обсягом вкАадень на душу населення в ІСІ,дӧх,доходів).,Аинаміка сукупного індексу була практично незмінною протягом аналізованого періоду та свідчить про недієвість ІСІ в процесі алокації фінансових ресурсів населення країни. Наступним кроком стала оцінка охоплення населення областей країни фінансовими послугами (ICI) та ї ранжування відносно середнього значення по Україні. Проведені розрахунки довели наявність регіональної асиметрії охоплення цими послугами. Це, досліАження дало можливість оцінити реальний стан охоплення населення країни фінансовими поСА угами ІСІ Та актуалізувало подальші, ослідження причин низького рівня взаємодї̈ населення із інСтитутами спільного інвестування.

Цінність дослідження полягає в тому, що на основі запропонованого автором методичного інструментарію оцінено реальний стан охоплення населення крайни та областей фінансовими посл угами інститутів спільного інвестування.

Research objective. To evaluate the coverage of country and regional population by collective investment funds' financial services based on the conducted analysis.

Methods of research. For the evaluation of the coverage of population of the country and regions by the financial services of collective investment funds, author used the methods of analysis and synthesis, graphics method of research, economic and statistic methods of data accumulation and processing, such as: sample research, grouping and statistical comparison of quantities, trend analysis, analysis of coefficients and relative values. Also for formulation of conclusions the method of logical generalization was used.

Findings. Using the general indicator of the coverage of the population of the country by the financial services of collective investment funds the author evaluated the level of the coverage during 2009 -2017 years. It was calculated on the basis of four components: population, volume of assets, volume of collective investments of 


\section{ЕКОНОМІЧНА НАУКА}

individuals and the shares in their relative incomes. The dynamic of the general indicator was virtually unchanged during the analysis period. It showed the ineffectiveness of the collective funds in the financial resources allocation process. The next step was the evaluation of the coverage of the population of the regions by the financial services of these funds and their grouping compared to the average level in Ukraine. The calculations demonstrated the reality of regional asymmetry of the coverage of the population by these services. The research gave the possibility to evaluate the real level of the coverage of the population of the country by the financial services of collective investment funds and actualized the further research of the reasons of the low level of the interaction between population and the these funds.

Value Added is that author evaluated the real level of coverage of the population of the country and regions by the financial services of collective investment funds using special methodical toolkits.

Ключові слова: інститут спільного інвестування, охоплення, регіональна асиметрія, фінансова послуга. Key words: collective investment funds, coverage, regional asymmetry, financial services.

\section{ПОСТАНОВКА ПРОБЛЕМИ У ЗАГАЛЬНОМУ ВИГЛЯДІ ТА ІЇ ЗВ'ЯЗОК З ПРАКТИЧНИМИ ЗАВДАННЯМИ}

Сучасний ринок цінних паперів забезпечує ефективність взаємодії між усіма елементами економічної системи. Його суб'єкти формують дієві механізми для функціонування та розвитку, оптимізуючи рух фінансових активів, забезпечують акумулювання заощаджень та подальше їх розміщення. Насамперед основною діяльністю на ринку цінних паперів є інвестиційна діяльність, активними учасниками якої виступають інституційні інвестори - інститути спільного інвестування (ICI). На ринку цінних паперів ICI залучають фінансові ресурси фізичних та юридичних осіб, формуючи пул фінансових активів - інвестиційний фонд; вкладають акумульовані фінансові ресурси в інструменти ринку цінних паперів та управляють даним пулом активів 3 метою збереження його вартості та одержання додаткової дохідності. Кількісний вплив фінансових активів, обіг яких здійснюється на ринку цінних паперів, на суспільне виробництво визначається обсягом фінансових ресурсів, що мобілізуються та розподіляються за допомогою інститутів спільно інвестування. Проте важливим $є$ не сам обсяг наданих фінансових послуг у процесі торгівлі фінансовими активами, а процес їх формуван- ня, форми та умови використання. Позитивний вплив на економіку залежить від дієвої взаємодії інститутів спільного інвестування, з одного боку, та інвесторів і емітентів, з іншого боку, для забезпечення алокативної ефективності та зниження трансакційних витрат у процесі інвестування. При цьому важливою є оцінка того, наскільки населення країни - потенційні інвестори на ринку цінних паперів є охоплені фінансовими послугами інститутів спільного інвестування.

\section{АНАЛІЗ ОСТАННІХ ДОСЛІДЖЕНЬ І ПУБЛІКАЦІЙ, В ЯКИХ ЗАПОЧАТКОВАНО РОЗВ'ЯЗАННЯ ДАНОЇ ПРОБЛЕМИ, ВИДІЛЕННЯ НЕ ВИРІШЕНИХ РАНІШЕ ЧАСТИН ЗАГАЛЬНОЇ ПРОБЛЕМИ, КОТРИМ ПРИСВЯЧУЄТЬСЯ ОЗНАЧЕНА СТАТТЯ}

Аослідженню особливостей і тенденцій формування та розвитку ринку цінних паперів загалом та сфери фінансових послуг зокрема, значну увагу приділяють вітчизняні науковці М. Гапонюк [1], І. Гуцал [2], Ю. Коваленко [3], Т. Майорова [4], І. Рекуненко [5], С. Хоружий [6], В. Федосов [7], В. Шелудько [8]. Інші науковці, зокрема, О. Білик [9], Н. Аегтярьова [9], О. Ажусов [10],

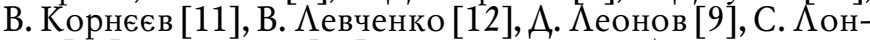
дар [13], С. Онишко [14] досліджують особливості діяльності інститутів спільного інвестування як учасників

Таблиця 1. Аналітичні показники забезпечення фінансовими послугами ICI в Україні протягом 2009-2017 рр.

\begin{tabular}{|l|l|l|l|l|l|l|l|l|l|l|}
\hline \multicolumn{1}{|c|}{ Показник } & \multicolumn{1}{c|}{2008} & 2009 & 2010 & 2011 & 2012 & 2013 & 2014 & 2015 & 2016 & 2017 \\
\hline $\begin{array}{l}\text { Кількість ICI: } \\
\text { - на 1000 км }\end{array}$ & 1,47 & 1,63 & 1,81 & 1,86 & 2,02 & 2,07 & 1,97 & 1,90 & 1,87 \\
\hline $\begin{array}{l}\text { - на 100 тис. осіб } \\
\text { населення }\end{array}$ & 2,759 & 3,062 & 3,408 & 3,501 & 3,820 & 3,925 & 3,759 & 3,870 & 3,853 & 3,998 \\
\hline $\begin{array}{l}\text { Кількість КУА: } \\
\text { - на 1000 км }\end{array}$ & 0,68 & 0,59 & 0,53 & 0,54 & 0,54 & 0,54 & 0,53 & 0,49 & 0,46 & 0,47 \\
\hline $\begin{array}{l}\text { - на 100 тис. осіб } \\
\text { населення }\end{array}$ & 1,271 & 1,104 & 0,996 & 1,011 & 1,025 & 1,030 & 1,009 & 1,006 & 0,951 & 0,979 \\
\hline $\begin{array}{l}\text { Відношення вкладень } \\
\text { фізичних осіб в ІСІ до } \\
\text { ВВП, \% }\end{array}$ & 0,58 & 0,36 & 0,33 & 0,33 & 0,48 & 0,63 & 0,79 & 0,87 & 0,99 & 0,99 \\
\hline
\end{tabular}

Ажерело: розраховано автором за даними УАІБ [15]. 
Таблиця 2. Оцінка охоплення населення фінансовими послугами ICI протягом 2008-2017 pp.

\begin{tabular}{|c|c|c|c|c|c|c|c|c|c|c|}
\hline Показники & 2008 & 2009 & 2010 & 2011 & 2012 & 2013 & 2014 & 2015 & 2016 & 2017 \\
\hline Кількість КУА, шт. & 411 & 389 & 361 & 360 & 358 & 349 & 345 & 320 & 300 & 296 \\
\hline Кількість ICI, шт. & 888 & 985 & 1095 & 1125 & 1222 & 1250 & 1188 & 1147 & 1131 & 1160 \\
\hline $\begin{array}{l}\text { Активи ICI, } \\
\text { млрд грн }\end{array}$ & 63,27 & 82,54 & 105,87 & 126,80 & 157,20 & 177,52 & 206,36 & 236,18 & 230,19 & 263,48 \\
\hline $\begin{array}{l}\text { Вкладення фізичних } \\
\text { осіб в ICI, млрд грн }\end{array}$ & 5,50 & 3,29 & 3,61 & 4,33 & 6,70 & 9,20 & 12,36 & 17,22 & 23,66 & 29,46 \\
\hline ВВП, млрд грн & 948 & 913 & 1079,3 & 1300 & 1404,7 & 1465,2 & 1586,9 & 1979,5 & 2383,2 & 2982,0 \\
\hline $\begin{array}{l}\text { Чисельність } \\
\text { населення, млн осіб }\end{array}$ & 46,37 & 46,14 & 45,96 & 45,78 & 45,63 & 45,55 & 45,43 & 42,93 & 42,76 & 42,38 \\
\hline $\begin{array}{l}\text { Грошові доходи на } \\
\text { душу населення, грн }\end{array}$ & 11736 & 12316 & 14370 & 15874 & 17542 & 18880 & 19357 & 21670 & 24955 & 28745 \\
\hline$I_{c}$ & 0,0182 & 0,0154 & 0,0154 & 0,0158 & 0,0198 & 0,0231 & 0,0263 & 0,0285 & 0,0290 & 0,0292 \\
\hline$I_{1}$ & 0,0280 & 0,0298 & 0,0317 & 0,0324 & 0,0346 & 0,0351 & 0,0337 & 0,0342 & 0,0335 & 0,0344 \\
\hline$I_{2}$ & 0,0667 & 0,0904 & 0,0981 & 0,0975 & 0,1119 & 0,1212 & 0,1300 & 0,1193 & 0,0966 & 0,0884 \\
\hline$I_{3}$ & 0,0058 & 0,0036 & 0,0033 & 0,0033 & 0,0048 & 0,0063 & 0,0078 & 0,0087 & 0,0099 & 0,0099 \\
\hline$I_{4}$ & 0,0101 & 0,0058 & 0,0055 & 0,0060 & 0,0084 & 0,0107 & 0,0141 & 0,0185 & 0,0222 & 0,0242 \\
\hline
\end{tabular}

Ажерело: розраховано автором за даними Аержкомстату [17] та УАІБ [15].

ринку цінних паперів. Не заперечуючи вагомий внесок цих авторів у формуванні теоретичних засад та практичних рекомендацій розвитку інститутів спільного інвестування на ринку цінних паперів України, не розкритими залишаються питання охоплення населення країни фінансовими послугами цих інституцій.

\section{ПОСТАНОВКА ЗАВДАННЯ}

Мета роботи - оцінка охоплення населення країни та областей фінансовими послугами інститутів спільного інвестування.

\section{ВИКЛАД ОСНОВНОГО МАТЕРІАЛУ ДОСЛІДЖЕННЯ ІЗ ОБГРУНТУВАННЯМ ОДЕРЖАНИХ НАУКОВИХ РЕЗУЛЬТАТІВ}

Розрахункові значення показників забезпечення фінансовими послугами ICI в Україні наведено в таблиці 1.

Аинаміка зміни кількісного складу компаній з управління активами (КУА) на ринку цінних паперів свідчить про зменшення їх кількості внаслідок фінансової кризи 2008 року до кінця аналізованого періоду. У 2017 р. у середньому на 1 КУА припадало 4,08 ICI, що є незначним, враховуючи те, що дохід КУА формується перш за все за рахунок винагороди ICI, які знаходяться в їі управлінні [15]. Тому зниження кількості КУА на ринку паралельно із збільшенням кількості ICI не розглядається нами як негативний факт, а радше як "укрупнення ринку" та його очищення від дрібних, неефективних компаній з управління активами.
Незважаючи на загальну позитивну динаміку кількісних показників ICI на ринку цінних паперів, показник, який оцінює частку вкладень населення в ICI до ВВП країни, залишається надзвичайно мізерним та практично недосяжним до аналогічного показника у країнах з розвинутою економікою [16].

Аля оцінювання рівня охоплення населення України фінансовими послугами ICI (табл. 2) було запропоновано розраховувати сукупний індекс охоплення $I_{c}$ за формулою (1):

$$
I_{c}=\sqrt[4]{I_{1} * I_{2} * I_{3} * I_{4}}
$$

на основі наступних його складових:

- індекс охоплення фінансовими послугами ICI (за чисельністю населення: на 1000 осіб) за формулою (2):

$$
I_{1}=\frac{\text { Кількість_КУА +Кількість_ICI }}{\text { Чисельність_населення }}
$$

— індекс охоплення фінансовими послугами ICI (за обсягом активів ICI) за формулою (3):

$$
I_{2}=\frac{\text { Активи_ICI }}{\text { ВВП }}
$$

- індекс охоплення фінансовими послугами ICI (за обсягом вкладень фізичних осіб в ICI) за формулою (4):

$$
I_{3}=\frac{\text { вкладення_фізосіб_в_ICI }}{\text { ВВП }}
$$

\begin{tabular}{|c|c|c|c|c|c|c|c|c|}
\hline Регіон & $\begin{array}{l}\text { Кількість } \\
\text { КУА, шт. }\end{array}$ & $\begin{array}{l}\text { Кількість } \\
\text { ICI, шт. }\end{array}$ & $\begin{array}{c}\text { Активи ICI, } \\
\text { млн грн }\end{array}$ & $\begin{array}{c}\text { ВРП, } \\
\text { млн грн }\end{array}$ & $\begin{array}{c}\text { Чисельність } \\
\text { населе- } \\
\text { ння, млн осіб }\end{array}$ & $I_{1}$ & $I_{2}$ & $I_{c}$ \\
\hline $\begin{array}{l}\text { м. Київ та Київська } \\
\text { обл. }\end{array}$ & 211 & 824 & 186058,5 & 555730 & 4,6603 & 0,222089 & 0,3348 & 0,272682 \\
\hline $\begin{array}{l}\text { Дніпропетровська } \\
\text { обл. }\end{array}$ & 21 & 87 & 18261,71 & 215206 & 3,2304 & 0,033432 & 0,084857 & 0,053263 \\
\hline Харківська область & 18 & 66 & 9117,003 & 124843 & 2,7012 & 0,031097 & 0,073028 & 0,047655 \\
\hline Донецька область & 4 & 10 & 1523,373 & 115012 & 4,244 & 0,003299 & 0,013245 & 0,00661 \\
\hline Полтавська область & 4 & 19 & 478,3046 & 95867 & 1,4268 & 0,01612 & 0,004989 & 0,008968 \\
\hline Запорізька область & 4 & 29 & 7347,348 & 89061 & 1,7395 & 0,018971 & 0,082498 & 0,039561 \\
\hline $\begin{array}{l}\text { Івано-Франківська } \\
\text { область }\end{array}$ & 4 & 29 & 724,0473 & 45854 & 1,3799 & 0,023915 & 0,01579 & 0,019432 \\
\hline
\end{tabular}

- індекс охоплення фінансовими послугами ICI (за обсягом вкладень на душу населення в ICI до їх доходів)

Таблиця 3. Показники охоплення населення областей України фінансовими послугами ICI в 2017 році

Ажерело: розраховано автором за даними УАІБ [15] та Аержкомстату [17]. 


\section{ЕКОНОМІЧНА НАУКА}

Таблиця 4. Групування областей України за показником $I_{1}$

\begin{tabular}{|c|c|c|c|c|c|}
\hline \multicolumn{2}{|c|}{ І група } & \multicolumn{2}{|c|}{ II група } & \multicolumn{2}{|l|}{ III група } \\
\hline Область & Значення & Область & Значення & Область & Значення \\
\hline \multirow{5}{*}{$\begin{array}{l}\text { м. Київ та } \\
\text { Київська } \\
\text { область }\end{array}$} & \multirow[t]{5}{*}{6,629514} & $\begin{array}{l}\text { Дніпропетровська } \\
\text { область }\end{array}$ & 0,997982 & Полтавська область & 0,481194 \\
\hline & & Харківська область & 0,928277 & Одеська область & 0,262672 \\
\hline & & $\begin{array}{l}\text { Івано-Франківська } \\
\text { область }\end{array}$ & 0,713874 & Донецька область & 0,098471 \\
\hline & & Запорізька область & 0,566298 & \multirow{2}{*}{$\begin{array}{l}\text { Інші області (3 } \\
\text { урахуванням АРК та } \\
\text { м. Севастополь) }\end{array}$} & \multirow[t]{2}{*}{0,044086} \\
\hline & & Львівська область & 0,565444 & & \\
\hline
\end{tabular}

Ажерело: розраховано автором.

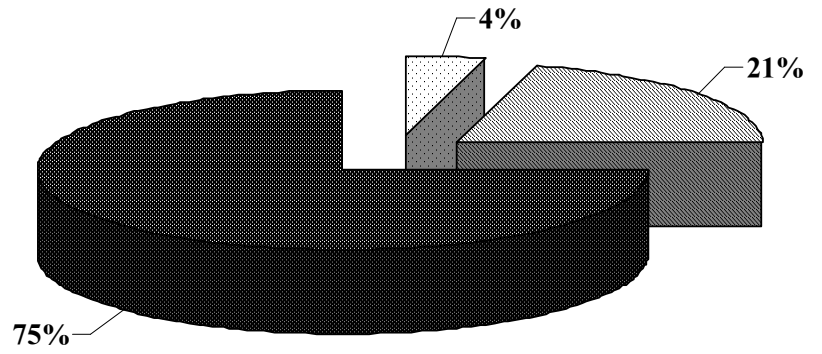

$\checkmark$ високий рівень забезпечення

$\mathbb{Q}$ середній рівень забезпечення

низький рівень забезпечення

Рис. 1. Групування областей України за показником $I_{1}$

Ажерело: розроблено автором.

за формулою (5):

$I_{4}=$ Вкладення_фізосіб_в_ICI//

/Грошові_доходи_на_душу_населення (5).

Розрахунок показників охоплення населення фінансовими послугами ICI в Україні дозволяє зробити такі висновки:

- показник охоплення фінансовими послугами ICI за обсягом їх активів хоча і збільшився в динаміці протягом аналізованого періоду на $30 \%$, проте загалом його значення залишається на досить низькому рівні;

- показник охоплення фінансовими послугами ICI за чисельністю населення збільшується практично вдвічі протягом аналізованого періоду, відтак у 2017 році на 100000 осіб припадало 2,9 ICI;

- за обсягом вкладень фізичних осіб в ICI рівень ї охоплення фінансовими послугами знаходиться на низькому рівні та характеризує пасивну діяльність населення країни у сфері колективного інвестування;

- позитивна динаміка спостерігається лише щодо четвертого показника охоплення фінансовими послугами ICI за обсягом вкладів. Зростання більш як удвічі

протягом аналізованого періоду пояснюється перш за все збільшенням доходів населення країни. Хоча у порівнянні 3 європейськими країнами значення цього показника знаходиться на достатньо низькому рівні та пояснюється нестабільною соціально-економічною ситуацією в країні та девальвацією національної валюти. Безумовно, вирішення політичного конфлікту та стабілізація економічного стану країни дозволили б збільшити темпи приросту активів ICI від вкладень фізичних осіб;

- динаміка сукупного індексу є практично незмінною і становить в середньому $+6,7 \%$ протягом аналізованого періоду. Висновок: сьогодні інститути спільного інвестування не є дієвим та ефективним інструментом алокації фінансових ресурсів населення країни.

Низький рівень показників охоплення населення фінансовими послугами ICI в Україні частково можна пояснити наявною регіональною асиметрією охоплення цих послуг. Це підтверджують проведені нами розрахунки показників охоплення населення фінансовими послугами ICI у кожній з областей України та порівняно із середнім значенням по Україні (табл. 3). ників:

3 метою систематизації областей розрахунок показ-

Таблиця 5. Групування областей України за показником $I_{2}$

\begin{tabular}{|c|c|c|c|c|c|}
\hline \multicolumn{2}{|c|}{ І група } & \multicolumn{2}{|c|}{ II група } & \multicolumn{2}{|l|}{ III група } \\
\hline Область & Значення & Область & Значення & Область & Значення \\
\hline \multirow{6}{*}{$\begin{array}{l}\text { м. Київ та } \\
\text { Київська } \\
\text { область }\end{array}$} & \multirow[t]{6}{*}{3,46584} & \multirow{3}{*}{$\begin{array}{l}\text { Дніпропетровська } \\
\text { область }\end{array}$} & \multirow[t]{3}{*}{0,878436} & Львівська область & 0,49408 \\
\hline & & & & Івано-Франківська область & 0,16346 \\
\hline & & & & Одеська область & 0,098129 \\
\hline & & \multirow[t]{2}{*}{ Харківська область } & \multirow[t]{2}{*}{0,755981} & Полтавська область & 0,051649 \\
\hline & & & & Донецька область & 0,137115 \\
\hline & & Запорізька область & 0,854016 & $\begin{array}{l}\text { Інші регіони } \\
\text { (з урахуванням АРК та } \\
\text { м. Севастополь) }\end{array}$ & 0,02272 \\
\hline
\end{tabular}

Ажерело: розроблено автором. 


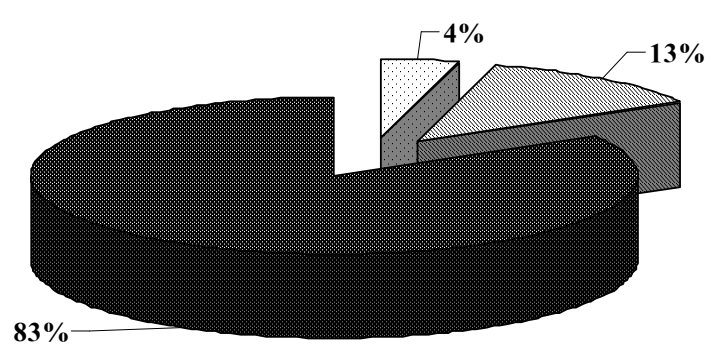

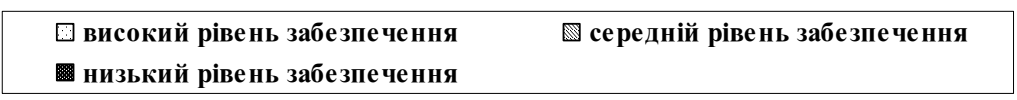

Рис. 2. Групування областей України за показником

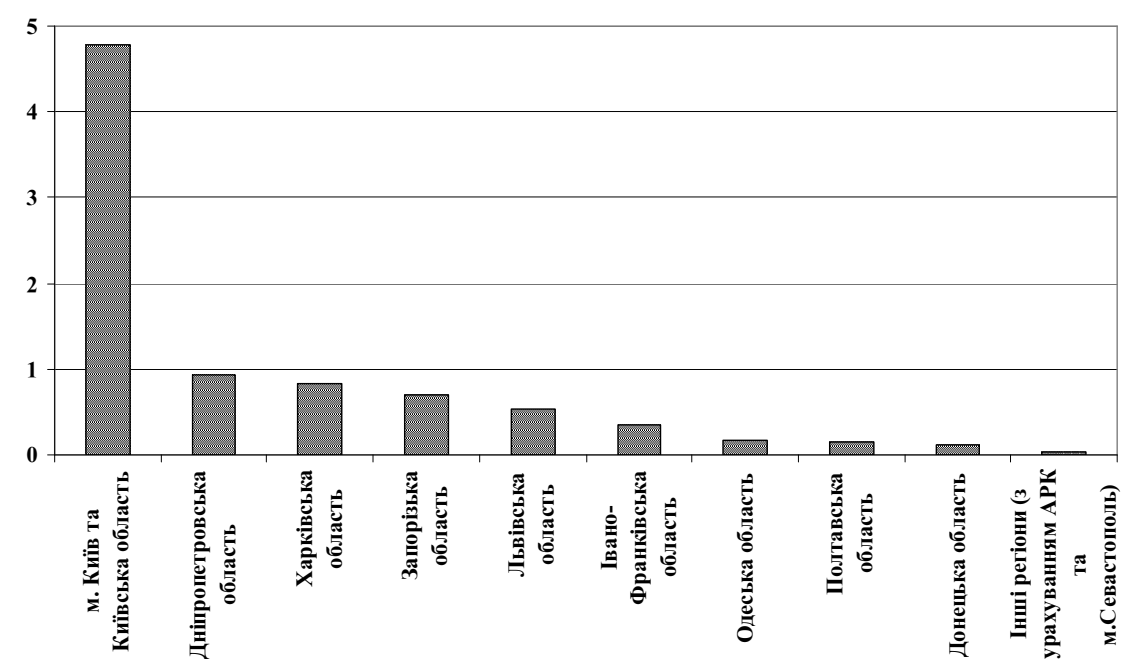

Рис. 3. Групування областей України за показником

Ажерело: розроблено автором.

- $I_{1}$ здійснюється за наступною формулою:

$I_{1}=\frac{K_{p}}{4 H_{p}} / \frac{K_{3}}{4 H_{3}}$

де $K_{p}$ - кількість діючих ICI в межах області;

Чн ${ }_{p}{ }^{p}$ чисельність населення в межах області;

$K_{3}$ - кількість діючих ICI в Україні;

Чн $_{3}$ - чисельність населення в Україні;

- $I_{2}$ аналогічно до попереднього розрахунку за формулою:

$$
I_{2}=\frac{A_{p}}{B P \Pi_{p}} / \frac{A_{3}}{B P \Pi_{3}}
$$

де $A_{p}$ - обсяг активів діючих ICI в області; ласті;

$B P \Pi_{p}$ - обсяг валового регіонального продукту об-

$A_{3}$ - обсяг активів діючих ICI в Україні;

$B P \Pi_{3}$ - обсяг валового регіонального продукту в Україні.

- сукупний індекс охоплення населення фінансовими послугами ICI в області за формулою:

$$
I_{c}=\sqrt[2]{I_{1} * I_{2}}
$$

Проведені розрахунки показника $I_{1}$ (індексу забезпечення фінансовими послугами ICI за чисельністю населення області) та його порівняння із середнім значення $I_{1}$ по Україні дозволяють згрупувати всі області в 3 групи: 3 високим рівнем охоплення фінансовими послугами ICI $\left(I_{1}>1\right)$, із задовільним рівнем охоплення $\left(0,5<I_{1}<1\right)$ та із незадовільним рівнем охоплення фінансовими послугами ICI $\left(I_{1}<0,5\right)$ (табл. 4).

Таким чином, у 2017 році склалась наступна ситуація: Київська обл. та м. Київ характеризуються високим рівнем охоплення фінансовими послугами ICI (показник перевищує більш як у 6 раз середнє значення по
Україні), 5 - із задовільним рівнем охоплення та решта 18 областей - із незадовільним рівнем охоплення фінансовими послугами ICI (рис. 1).

Наступним кроком є оцінювання індексу охоплення ICI фінансовими послугами за обсягом їх активів. Аналіз проведених розрахунків підтверджує наявність значного рівня охоплення населення фінансовими послугами ICI саме в м. Київ та Київській області, тимчасом як майже дві третини населення областей не охоплені достатньою кількістю цих послуг (табл. 5 та рис. 2): Івано-Франківська та $\Lambda$ ьвівська області із групи із задовільним рівнем охоплення фінансовими послугами ICI (за показником $I_{1}$ ) перейшли в групу із незадовільним рівнем охоплення.

Останнім кроком є розрахунок сукупного індексу охоплення населення фінансовими послугами ICI в регіонах України. Відтак порівняння $I_{c}$ в областях із середнім значенням по Україні характеризують незадовільний стан охоплення населення областей фінансовими послугами ICI (рис. 3).

\section{ВИСНОВКИ З ПРОВЕДЕНОГО ДОСЛІДЖЕННЯ І ПЕРСПЕКТИВИ ПОДАЛЬШИХ РОЗВІДОК У ЦЬОМУ НАПРЯМІ}

На основі застосування методичного інструментарію автору вдалося показати реальну картину охоплення населення фінансовими послугами ICI як в Україні, так і в областях. Чому це важливо досліджувати саме сьогодні? Триває пенсійна реформа, очікується запуск другого рівня пенсійної системи, відтак мільйони громадян будуть інвестувати свої заощадження в інструменти ринків капіталу. За умов низького рівня фінансової грамотності посилюватиметься роль інститутів спільного інвестування як професійних учасників ринку цінних паперів. 
Слід розуміти, що охоплення населення фінансовими послугами ICI, можливість залучення ними фінансових заощаджень населення обумовлюється діючим інституційним середовищем ринку цінних паперів. Чинників, які обумовлюють небажання населення країни співпрацювати із фондами колективного інвестування багато, проте перш за все це низький рівнень довіри до цих інституцій. А довіра - це фундамент, на якому будується діяльність ICI. Відтак дослідження стану довіри до ICI як фінансового посередника стане предметом наших подальших досліджень.

\section{$\Lambda$ ітература:}

1. Гапонюк М.А. Інфраструктура фондового ринку України: проблемні питання та перспективи розвитку / М. А. Гапонюк // Збірник праць Національного університету державної податкової служби України. - 2010. - № 2. - С. 36-44.

2. Гуцал I.C. Теоретико-методологічні домінанти формування та пріоритети розвитку ринку фінансових послуг України: монографія / О.В. Кнейслер, I.С. Гуцал, О.Р. Квасовський та ін.; за ред. О. В. Кнейслер. Тернопіль: ТHEУ, 2017. - 246 с.

3. Коваленко Ю. Фінансові послуги: сутність і класифікація / Ю. Коваленко // Світ фінансів. - 2012. Вип. 3. - С. 162-169.

4. Майорова Т.В., Петренко I.П. Проблеми трансформації заощаджень в інвестиції на фінансовому ринку України // Інвестиції: практика та досвід. - 2015. № 6. - C. $11-17$.

5. Рекуненко I.I. Інфраструктура фінансового ринку: сучасний стан та перспективи розвитку: монографія. - Суми: АВНЗ "УАБС НБУ", 2013. - 411 с.

6. Хоружий С.Г. Фінансові послуги: зміст, значення та перелік. Ринок цінних паперів України. - 2016. № $7-8 .-$ C. $83-92$.

7. Фінансова інфраструктура України: стан, проблеми та перспективи розвитку: монографія / В. Опарін, В. Федосов, С. Аьовочкін та ін.; за заг. ред. В. Опаріна, В. Федосова. - K.: КНЕУ, 2016. - 695 с.

8. Шелудько В. М. Роль венчурного фінансування у комерціалізації об'єктів інтелектуальної власності / B.М. Шелудько, В.В. Вірченко // Теоретичні та прикладні питання економіки, 2012. - С. 168-176.

9. Аегтярьова Н.В., Аолінський А.Б., Аеонов А.А. Управління активами в Україні: навчальний посібник/ за заг. ред. Аеонова А.А. - К.: УІРФР, 2015. - 276 с.

10. Ажусов О.А. Інвестиційні стратегїі інституційних інвесторів: монографія / О. А.Ажусов. - А.: Наука i освіта, 2005. - 206 c.

11. Корнєєв В.В. Розвиток фінансового сектору України та захист прав інвесторів в контексті інтеграції міжнародних інвестиційних ринків / В.В. Корнєєв // Фінанси, облік і аудит. - 2017, вип. 1 (29). - С. $122-$ 133.

12. Мевченко В.П. Розвиток ринку небанківських фінансових послуг: монографія / В.П. Аевченко - К.: Центр учбової літератури, 2013. - 368 с.

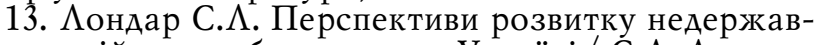
ного пенсійного забезпечення в Україні / С. $\Lambda$. Цондар,

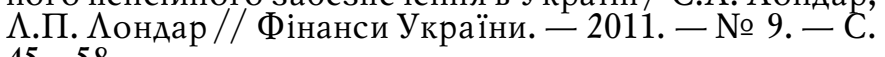
$45-58$.

14. Онишко С.В. Управління фінансовими активами як інструмент забезпечення ефективності фінансового ринку / С. В. Онишко// Науковий вісник Чернігівського державного інституту економіки і управління. Сер. 1: Економіка. - 2014. - Вип. 2. - С. 105-110.

15. Аналітичний огляд ринку управління активами в Україні [Електронний ресурс] // Українська асоціація інвестиційного бізнесу. - 2018. - Режим доступу до pecypcy: http://www.uaib.com.ua/files/articles/1954/11/ 2017-f.pdf

16. A Review of Trends and Activities in the Investment Company Industry [Електронний ресурс]// Investment company institute. - 2017. - Режим доступу до ресурcy: https://www.ici.org/pdf/2017_factbook.pdf

17. Статистична інформація [Електронний ресурс] // Аержавна служба статистики України. - 2018. - Режим доступу до ресурсу: http://www.ukrstat.gov.ua

\section{References:}

1. Gaponyuk, M.A. (2010), "Infrastructure of the Ukrainian Stock Market: Problem Issues and Development Prospects", Zbirnyk prats' Natsional'noho universytetu derzhavnoyi podatkovoyi sluzhby Ukrayiny, vol. 2, pp. 36-44.

2. Gutsal, I.S. (2017), Teoretyko-metodolohichni dominanty formuvannya ta priorytety rozvytku rynku finansovykh posluh Ukrayiny [Theoretical and methodological dominant of formation and priorities of the development of the financial services market in Ukraine]. TNEU, Ternopil, Ukraine.

3. Kovalenko, Yu. (2012), "Financial Services: Essence and Classification", Svit finansiv, vol. 3, pp. 162-169.

4. Mayorova, T.V. Petrenko, I.P. (2015), "Problems of transformation of savings in investments in the financial market of Ukraine", Investments: practice and experience, vol. 6 , pp. $11-17$.

5. Rekunenko, I.I. (2013), Infrastruktura finansovoho rynku: suchasnyy stan ta perspektyvy rozvytku [Infrastructure of the financial market: the current state and prospects of development]. DVNZ "UABS NBU", Sumy, Ukraine.

6. Khoruzhyy, S.H. (2016), "Financial Services: Content, Value and List", Rynok tsinnykh paperiv Ukrayiny, vol. 7 8, pp. 83-92.

7. Fedosov, V. and Oparin, V. (2016) Finansova infrastruktura Ukrayiny: stan, problemy ta perspektyvy rozvyt$\mathrm{ku}$ [Financial infrastructure of Ukraine: state, problems and prospects of development], KNEU, Kyiv, Ukraine.

8. Shelud'ko, V.M. (2012), "The role of venture financing in the commercialization of intellectual property objects", Teoretychni ta prykladni pytannya ekonomiky, pp. $168-176$.

9. Dehtyar'ova, N. V. Dolins'kyy, L. B. and Leonov, D. A. Upravlinnya aktyvamy v Ukrayini [Asset Management in Ukraine], UIRFR. Kyiv, Ukraine.

10. Dzhusov, O. A. (2005), Investytsiyni stratehiyi instytutsiynykh investoriv. [Investment Strategies for Institutional Investors], Nauka i osvita, Donetsk, Ukraine.

11. Kornyeyev, V. V. (2017), "Development of the financial sector of Ukraine and protection of investors' rights in the context of integration of international investment markets", Finance, accounting and auditing, vol. 1 (29), pp. $122-133$.

12. Levchenko, V. P. (2013), Rozvytok rynku nebankivs'kykh finansovykh posluh [Development of the non-bank financial services market]. Tsentr uchbovoyi literatury, Kyiv, Ukraine.

13. Londar, S.L. and Londar, L.P. (2011), "Prospects for the development of non-state pension provision in Ukraine", Finance of Ukraine, no. 9, pp. 45-58.

14. Onyshko, S.V. (2014), "Financial asset management as a tool for ensuring the efficiency of the financial market" Naukovyy visnyk Chernihivs'koho derzhavnoho instytutu ekonomiky i upravlinnya. Seriya 1: Ekonomika, vol. 2, pp. $105-110$.

15. Ukrainian Association of Investment Business (2017). Analytical review of the asset management market in Ukraine, available at: http://www.uaib.com.ua/files/ articles/1954/11/2017-f.pdf (Accessed 20 October 2018).

16. Investment company institute (2018), "A Review of Trends and Activities in the Investment Company Industry", available at: https://www.ici.org/pdf/2017_factbook.pdf (Accessed 20 October 2018).

17. State Statistics Service of Ukraine (2018), "Statistical information", available at: http://www.ukrstat.gov.ua (Accessed 20 October 2018).

Стаття надійила до редакцї 01.11.2018 p. 
М.В.Руденко, к.е. н., дочент кафедри менеджменту та інформачійних технологій, Черкасъкий інститут АВНЗ "Університет банківської справи"

DOI: $10.32702 / 2306-6806.2018 .11 .61$

\title{
ЦИФРОВІЗАЦІЯ ЕКОНОМІКИ: НОВІ МОЖАИВОСТІ ТА ПЕРСПЕКТИВИ
}

\author{
M. Rudenko, \\ PhD (ECon.), associate Professor of the Department of management and information \\ technologies of Cherkasy institute of State higher educational institution "University of banking"
}

\section{DIGITALIZATION OF ECONOMY: NEW OPPORTUNITIES AND PERSPECTIVES}

Устатті,досліджено багатогранність та багатоаспектність визначення категорії "цифровізація"та надано авторське трактування наведеного поняття. Окреслено основні принципи цифровізації (закони, положення та рушійні сили просування інформаційно-комунікаційних технологій у повсякденне життя держави, підприємств та соціуму). Обгрунтовано, що процес цифровізації не с самоцілдю підприємства, регіону чи держави, а виступає дише інструментом, осягнення мети сталого розвитку. Проаналізовано можливості отримання позитивного ефекту ві, цифровізації дАя вітчизняної економіки $з$ позицій трьох основних суб'єктів - держави, підприемств та суспільства.

Виявлено, що досягнення позитивного ефекту від цифровізації на рівні держави вимагає інституціонального втручання влади у процеси формування необхідної нормативно-правової бази. Цифрова трансформація економіки державного управління відбувається переважно з використанням електронних каналів взаємодії, що дозволяє знизити трансакційні витрати. Обгрунтовано переваги цифровізації реального сектору економіки, оскільки посилюються конкурентні позиції вітчизняних підприємств за рахунок підвищення продуктивності праці, ефективності управління, прискореної автоматизації виробничих процесів, безпечності виробництва та підвищення привабливості вітчизняної економіки для інвестицій. УАослідженні також охарактеризовано переваги віА цифровізації,Ая суспільства та підкреслено, що кінцевими споживачами та користувачами цифрових продуктів і послуг виступає населення.

The versatility and multidimensionality of the definition of the category "digitalization" are researched in the article and the author's interpretation of the above concept is given. Digitization is a means of obtaining expected result that meets the requirements and needs of society and arranges the producers and owners of the business in terms of revenue opportunities. The basic principles of digitalization (laws, regulations and driving forces of promotion of information and communication technologies in everyday life of the state, enterprises and society) are outlined. There have been substantiated that the process of digitization is not the aim of itself for an enterprise, a region or a state, but serves only as a tool for achieving the goal of sustainable development. There have been proved that ignoring of digitalization processes and preservation of the usual model and algorithms of work in the unchanged form can lead to lagging behind competitors, which in future will be extremely problematic to eliminate. The possibilities of obtaining a positive effect from digitalization for the domestic economy from the standpoint of the three main subjects - the state, enterprises and society-are analyzed.

There have been founded that the achievement of the positive effect of digitalization at the state level requires an institutional intervention of the authorities in the process of forming the necessary regulatory framework. The digital transformation of the economy of state administration occurs mainly through the use of electronic channels of interaction, which reduces transaction costs. The advantages of digitization of the real economy sector are grounded, because of the competitive position of domestic enterprises is increased due to increase of labor productivity, efficiency of management, accelerated automation of production processes, safety of production and increase of attractiveness of the domestic economy for investments. The study also describes the benefits of digitalization for society and emphasizes that end-users of digital products and services are society.

Ключові слова: чифровізачія, економіка, інформачійно-комунікачійні технологї, держава, підприємство, cycniльcmbo.

Key words: digitalization, economy, information and communication technologies, state, enterprise, society.

\section{ПОСТАНОВКА ПРОБЛЕМИ}

Світ вступив у нову епоху цифрової глобалізації, яка визначається безперервними потоками даних, які містять інформацію, знання, ідеї та інновації. За про- гнозними даними експертів BCG (The Boston Consulting Group) до 2020 року приблизно $25 \%$ світової економіки перейде до впровадження технологій цифровізації, які дозволяють державі, бізнесу та суспільству функціону- 
вати більш ефективно. Розвинені країни, завершивши індустріалізацію, успішно цифровізують економіки, прискореними темпами розвиваючи інноваційні технології, де домінує штучний інтелект, автоматизація та цифрові платформи.

Розвиток вітчизняного суспільства, створення нових та модернізація існуючих технологій зумовлюють необхідність змін у "звичній" діяльності суб'єктів господарювання. XXI ст. значно актуалізувало сферу досліджень для науковців та практиків спричинену стрімким розвитком та поширенням інформаційно-комунікаційних і цифрових технологій. Вищезазначені технології виступають фундаментом цифрової економіки, інтерес до формування та розвитку якої посилюється 3 кожним роком не лише світовою, але і вітчизняною спільнотою. Підтвердженням наведеної думки на національному рівні є затверджена Кабінетом Міністрів України Концепція розвитку цифрової економіки та суспільства України на 2018-2020 роки [1].

Реалізація інформаційно-комунікаційних можливостей та переваг новітніх технологій, необхідність набуття лідируючих позицій і зміцнення конкурентоспроможності секторів економіки у глобалізованому цифровому світі вимагають від уряду зваженої політики щодо цифровізації, лібералізації регулювання, адаптації нормативної бази, стимулювання інвестицій для просування цифрової економіки, враховуючи власні традиції і спираючись на наукове підгрунтя теорій і концепцій економічного розвитку.

\section{АНАЛІЗ ОСТАННІХ ДОСЛІДЖЕНЬ І ПУБЛІКАЦІЙ}

Цифрова трансформація економік світу, процесів виробництва та надання послуг є однією 3 передових тенденцій, яку досліджують науковці, винахідники, журналісти та практики. Проблематика виявлення основних драйверів цифровізації економіки та їх значення для суспільного розвитку розкривається в наукових працях знаних зарубіжних вчених, серед яких

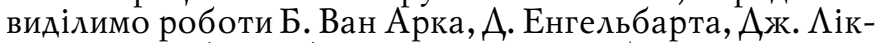
лайдера, Р. Міпсі, А. Стігліца та ін. Обгрунтовані ідеї щодо цифровізації економік висловлювали західні журналісти та практики - В. Айзексон, Аж. Вейлз, Б. Гейтс. Серед вітчизняних науковців досліджуваній проблематиці приділяли увагу О. Вишневський, В. Геєць, І. Карчева, С. Коляденко, Н. Краус, В. Аяшенко, В. Фіщук, К. Шваб [2-6] та багато інших.

Разом з тим зауважимо, що багатогранність, багатоаспектність та дискусійність окремих питань щодо цифровізації зумовлює необхідність подальших досліджень впливу інформаційно-комунікаційних (цифрових) технологій на розвиток економіки.

\section{ФОРМУЛЮВАННЯ ЦІЛЕЙ ДОСЛІДЖЕННЯ}

Метою статті $є$ дослідження теоретичних та прикладних аспектів цифровізації економіки на основі аналізу можливостей застосування інформаційно-комунікаційних (цифрових) технологій у практичну діяльність суб'єктів господарювання.

\section{ВИКЛАД ОСНОВНОГО МАТЕРІАЛУ}

Окремі науковці та практики рекомендують використовувати термін "цифровізація" як омонім, оскільки наведена категорія досить багатогранна та має значну кількість трактувань. Загальною метою цифровізаційних процесів в економіці є перебудова виробництва у більш гнучке та пристосоване до реалій сьогодення, що підвищує конкурентоспроможність держави у "цифровому світі". Цифровізація є засобом одержання очікуваного результату, який відповідає вимогам та потребам суспільства і влаштовує виробників та власників бізнесу щодо можливостей отримання високих прибутків.

Суб'єкти господарювання, які мають на меті перейти на "цифрові" рейки повинні фокусуватися на авто- матизації виробничих та управлінських процесів, з метою підвищення ефективності функціонування. Підприємство, яке робить акцент на "цифровізації", повинно націлюватися на дієву віддачу від цих процесів, через більш високу залученість співробітників до прийняття управлінських рішень.

Цифровізація економіки трактується науковцями T. Юдіною та I. Тушкановим [7] у вузькому та широкому значенні: у вузькому значенні - створення на різних рівнях економіки (глобальному, мега, макро, мезо, мікро, нано) інформаційно-цифрових платформ і операторів, які дозволяють вирішувати різні завдання, у тому числі стратегічні: розвиток медицини, науки, освіти, транспорту, нової індустріалізації, державного регулювання економіки і т.д.; у широкому сенсі - зміна природи виробничих або економічних відносин, зміну їх суб'єктивно-об'єктивної орієнтованості. За допомогою алгоритмів виникають відносини типу машина-машина (M2M), де людина може вже не виступати суб'єктом. Змінюються виробничі сили суспільства та (або) фактори виробництва [8, с. 197].

У схваленій урядовій Концепції розвитку цифрової економіки та суспільства України на 2018-2020 роки цифровізація розглядається як насичення фізичного світу електронно-цифровими пристроями, засобами, системами та налагодження електронно-комунікаційного обміну між ними, що фактично уможливлює інтегральну взаємодію віртуального та фізичного, тобто створює кіберфізичний простір [1].

B.I. Аяшенко та О.С. Вишневський розглядають процес цифровізації з позиції поділу економіки на три сектори (первинний - сільське господарство і видобуток корисних копалин, вторинний - промислове виробництво, третинний — послуги), то принциповою відмінністю $\epsilon$ не стільки збільшення частки третинного сектора або появи та розширення нового (цифрової економіки), а радикальне перетворення всіх трьох вже існуючих секторів [8, с. 8]. Позиція наведених науковців тісно корелює з ідеями закладеними К. Кларком та Ж. Фурастьє [9] у теорії постіндустріального суспільства, в якій поділ суспільного виробництва також ділився на три сектори за схожим принципом, науковці наголошували, що в майбутньому стрімко зростатиме частка третинного сектора економіки (сфера послуг) порівняно із сільським господарством та промисловістю.

Аослідницька та консалтингова компанія, що спеціалізується на ринках інформаційних технологій Gartner (штаб-квартира - Коннектикут, США) визначає цифровізацію як "використання цифрових технологій для зміни бізнес-моделі та надання нових можливостей для отримання доходів і створення вартості, процес переходу до цифрового бізнесу" [10], що дещо відрізняється від трактування цифровізації в академічних та наукових колах, оскільки практики фокусуються саме на зміні бізнес-моделей, а не на соціальних взаємодіях чи трансформаціях.

У сучасній енциклопедії інформатики та технологій цифровізація трактується як "інтеграція цифрових технологій у повсякденне життя суспільства шляхом оцифровки всього, що можна оцифрувати. Цифровізація означає комп'ютеризацію систем і робочих місць Аля більшої легкості та доступності" [11].

Керівник дирекції з цифрової трансформації "Газпром нафти" А. Бєлєвцев ототожнює цифровізацію з автоматизацією, "цифровізація в моєму розумінні - це як автоматизація. Тобто ми використовуємо цифрові технології, щоб поточні організаційні та виробничі процеси стали ефективнішими" [12, с. 25]. Вважаємо, що ототожнення цифровізації з автоматизацією $є$ не зовсім коректним, оскільки при автоматизації виробництва людина фактично звільняється від участі у процесах отримання, перетворення, передачі і використання енергії, матеріалів чи інформації, або істотно зменшує міру цієї участі чи трудомісткості виконуваних операцій, проте 


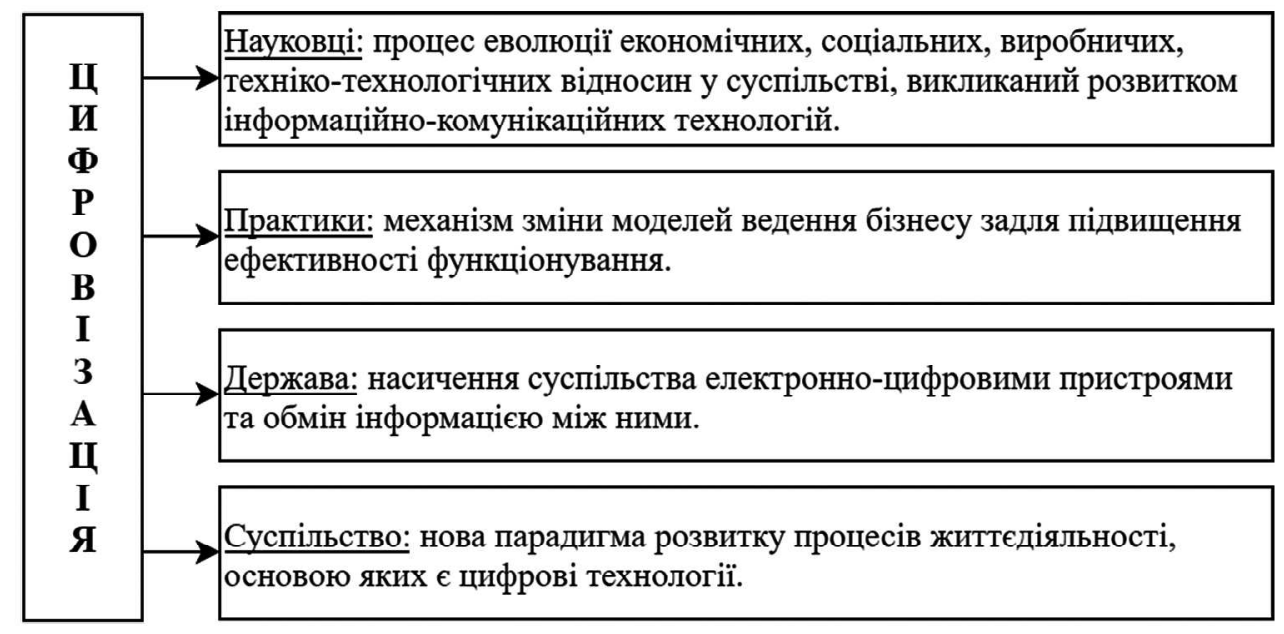

Рис. 1. Трактування категорії "цифровізація" з різних точок зору

Ажерело: систематизовано автором.

процес цифровізації дозволяє отримати принципово інші моделі управління, змінити характеристики роботи самого підприємства, порядку ведення бізнесу і т.д.

Цифровізація виробничих чи управлінських процесів не обмежується звичайною автоматизацією внутрішніх процесів підприємства, оскільки передбачає переведення частини роботи персоналу на програмне забезпечення. За рахунок цифровізації робочих процесів підприємства зменшують кількість дій, необхідних для виконання завдань, скорочується паперова робота, значно зменшується кількість помилок та підвищується продуктивність праці персоналу. Збереження звичайних алгоритмів роботи в незмінному вигляді може призвести до відставання від конкурентів, яке ліквідувати у подальшому буде дуже проблематичним.

Аиференціація авторського розуміння багатогранності трактування категорії "цифровізація" розглядається 3 чотирьох позицій - держави, науковців, практиків (підприємців) та суспільства (рис. 1), оскільки тлумачення вищенаведеного поняття значно видозмінюється в залежності від сфери його застосування, категорії осіб, які давали визначення та кінцевої мети надання.

3 наукової точки зору (звичайно у науковій спільноті немає єдності в цьому питанні) цифровізація - це процес еволюції економічних, соціальних, виробничих, техніко-технологічних, організаційних, управлінських, та інших відносин всередині суспільства, зміна їх суб'єктивно-об'єктивної орієнтованості, яка викликана розвитком інформаційно-комунікаційних (цифрових) технологій.

Аля переважної більшості практиків та бізнесменів, цифровізація - це механізм зміни загальної бізнес моделі ведення підприємництва задля отримання ними нових покращених характеристик роботи з метою оволодіння конкурентними перевагами, створення додаткової вартості та підвищення ефективності існуючих бізнес процесів.

Аержавні органи влади, а саме Кабінет міністрів України, трактує цифровізацію як фізичне насичення суспільства електронно-цифровими пристроями та прискорений обмін інформацією між ними, що дозволяє поступово стерти межу між віртуальним та фізичним світом.

Суспільство вбачає у цифровізації абсолютно нову парадигму розвитку нації, основану на повсякденному та повсюдному використанні цифрових технологій, що забезпечить оперативність обміну даними та швидкість доступу до інформації і бази знань.

Проведений аналіз наукової літератури дозволяє стверджувати, що специфіка трактування категорії "цифровізація" напряму залежить від суб'єкта надання визначення, що спричиняє неоднозначність трактування досліджуваного поняття та підкреслює дискусійність окремих положень і тверджень.

Значна кількість англомовних наукових праць, пов'язаних з розвитком і функціонуванням цифрової економіки [13-14], акцентує увагу на впливі цифровізації на ефективність функціонування економічної системи взагалі та виявленні механізмів і наслідків їі впливу на сталий розвиток окремих країн, регіонів, підприємств. Переконані у тому, що процес цифровізації не є самоціллю підприємства, регіону чи держави, а виступає лише інструментом досягнення мети сталого розвиткy.

Процес цифровізації економіки базується на узагальненні наявного практичного досвіду та сформульований у вигляді основних положень, обставин, вимог та практик, які покладені в його основу, тобто сукупності загальновизнаних правил, що виступають фундаментом (необхідною умовою) впровадження вищезазначеного процесу у повсякденне життя суб'єктів господарювання. Основні принципи цифровізації економіки та суспільства представлені на рисунку 2.

Принципи цифровізації економіки - основні закони, положення й рушійні сили просування інформаційно-комунікаційних технологій в повсякденне життя держави, підприємств та соціуму. Єдиним фундаментальним принципом цифровізації є ідея покращення процесів життєдіяльності людей за рахунок застосування сучасних технологій у різних сферах суспільного життя. Основою діяльності економічних суб'єктів, які функціонують 3 використанням основних принципів цифровізації є необхідність задоволення суспільних потреб найбільш ефективним - цифровим способом.

Цифровізація стрімко проникає в повсякденне життя людей, надаючи нові можливості для всіх секторів економіки України у розрізі модернізації методів роботи та управління, змінюючи виробничі процеси, канали реалізації та способи взаємодії з постачальниками та покупцями. Аеталізовано розглянемо деякі з цих можливостей для економіки України та дослідимо процеси цифровізації у контексті можливостей отримання позитивного ефекту для вітчизняної економіки з позицій трьох основних суб'єктів - держави, підприємств та суспільства (рис. 3).

Аосягнення позитивного ефекту від цифровізації на рівні держави вимагає інституціонального втручання влади у процеси формування необхідної нормативноправової бази (робота над удосконаленням існуючого законодавства). Інституційним поштовхом до цифровізації було прийняття Законів України про електронні довірчі послуги, про електронну комерцію, про технічні регламенти та оцінку відповідності, доопрацювання За- 


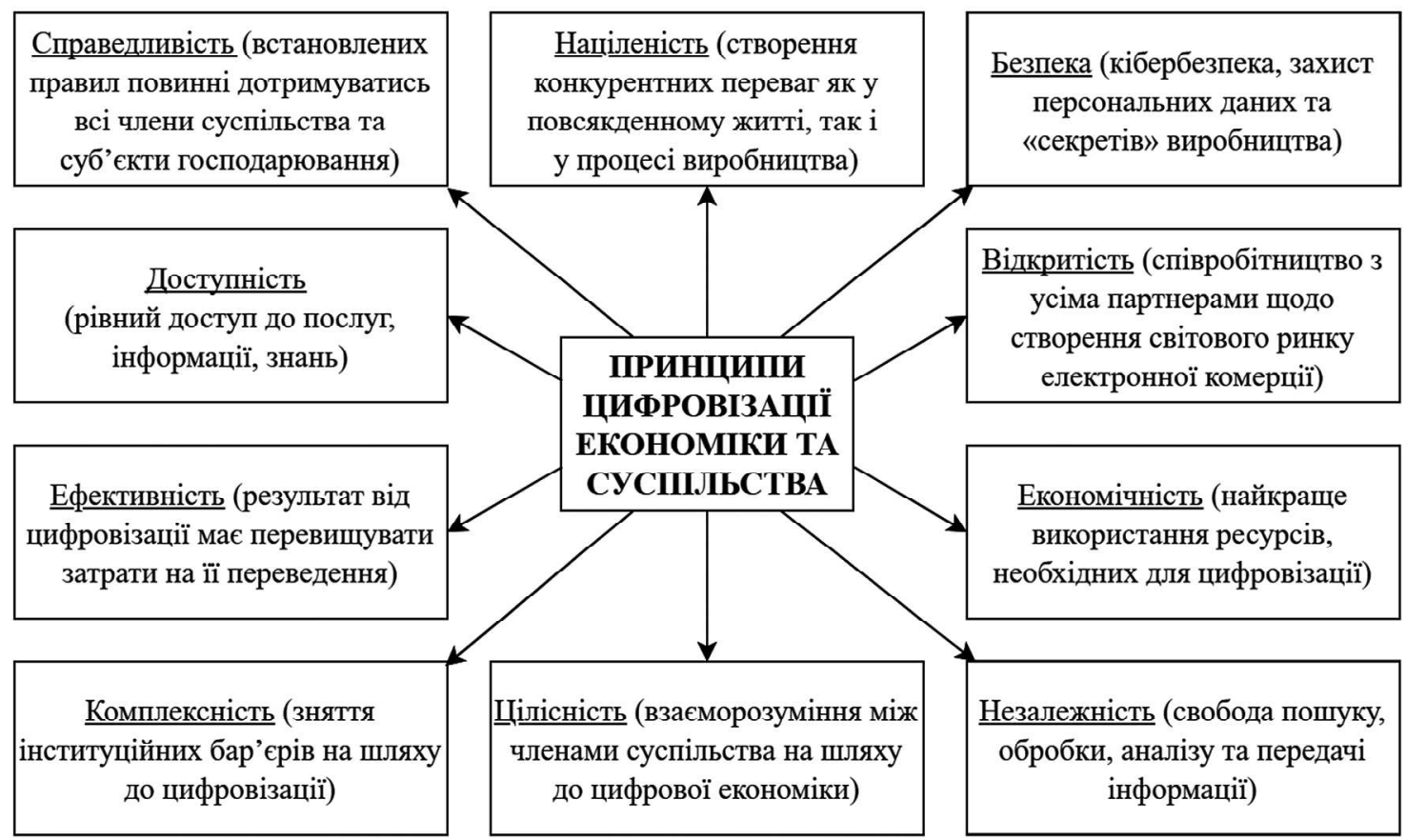

Рис. 2. Принципи цифровізації економіки та суспільства

конів України про інформацію, про захист інформації в інформаційно-телекомунікаційних системах і т.А. Вважаємо за необхідне зміцнювати законодавчу базу в інформаційно-комунікаційній сфері та проголосувати Закон України про використання держорганами хмарних технологій, поновити розгляд відкладеного Закону України про електронні комунікації, що відповідатиме вимогам часу, глобалізаційним цифровим процесам та зміцнить інституціональну основу цифровізації економіки держави.

Цифрова трансформація економіки державного управління відбувається переважно з використанням електронних каналів взаємодії для зниження трансакційних витрат, оскільки звичайні відносини замінюються електронним аналогом. Ці зміни повинні супроводжуватися трансформацією класичних інститутів для підвищення рівня довіри до електронної сфери.

Цифровізація реального сектору економіки зміцнить конкурентні позиції вітчизняних підприємств за рахунок підвищення продуктивності праці, ефективності управління, прискореної автоматизації виробничих процесів, безпечності виробництва та зробить галузі вітчизняної економіки більш привабливими для інвестицій.
Цифровізація процесів управління підприємствами та автоматизація прийняття рішень дозволяють знизити витрати на адміністративний персонал і підвищити ефективність керування організацією. Цифрові системи управління та системи збору та аналізу даних за останні $15-20$ років міцно закріпилися в бізнес-середовище, окресливши відповідні цифрові драйвери для підприємств. Використання автоматичного збору та аналізу даних, індустріальні ІоТ (Інтернет речей) сенсори, об'єднані платформи управління підприємствами, системи машинного навчання для прийняття оптимальних рішень і т.д. впроваджуються та удосконалюються у більшості великих підприємств та корпорацій. Цифровізація дозволяє знизити ризики в управлінні та нівелювати неповноту інформації при прийнятті рішень. При дотриманні норм інформаційної безпеки цифровізація здатна забезпечити зростання ефективності всіх управлінських процесів.

Переваги від цифровізації для суспільства очевидні, оскільки користувачами цифрових продуктів та послуг виступає саме населення, яке має змогу отримувати швидкісний доступ до Інтернету, інформації і бази знань, роблячи наше життя більш комфортним та зручним, тобто таким, що відповідає реаліям сьогодення.

\begin{tabular}{|c|c|c|}
\hline & ПОЗИТИВНИЙ ЕФЕКТ ВІД ЦИФРОВІЗАЩЇ & \\
\hline & & \\
\hline На рівні держави: & На рівні підприємства: & Для суспільства: \\
\hline $\begin{array}{l}\text { - новий стимул до зростання ВВП; } \\
\text { - підвищена інформаційна ефективність } \\
\text { при взаємодії з підприємствами та } \\
\text { населенням; } \\
\text { - зростання продуктивності операцій (збір } \\
\text { податків, надання послуг, управління } \\
\text { реєстрами тощо); } \\
\text { - мінімізація шахрайства у сфері послуг } \\
\text { державних органів влади; } \\
\text { - знижсння рівня тіньової скономіки; } \\
\text { - зміцнення довіри населення до державних } \\
\text { органів влади за рахунок прозорості та } \\
\text { відкритості. }\end{array}$ & $\begin{array}{l}\text { - зростання продуктивності праці за } \\
\text { рахунок цифровізагії бізнес-прогесів; } \\
\text { - підвищення ефективності управління; } \\
\text { - прозорість, простота та оперативність } \\
\text { взаємодії з держкавпими оргапами влади; } \\
\text { - прискорена автоматизація виробничих } \\
\text { процесів; } \\
\text { - можливість доступу до світових ринків; } \\
\text { - розширення каналів реалізації продукшії. } \\
\end{array}$ & $\begin{array}{l}\text { - оперативність обміну даними між } \\
\text { членами суспільства; } \\
\text { - швидкість доступу до інформації та бази } \\
\text { знань; } \\
\text { - удоскопалепшл товарів та послуг } \\
\text { відповідно до потреб та вимог населення; } \\
\text { - розвиток Інтернету речей (ІоТ); } \\
\text { - полегшений доступ до послуг державних } \\
\text { органів влади. }\end{array}$ \\
\hline
\end{tabular}

Рис. 3. Позитивний ефект від цифровізації економіки 


\section{ВИСНОВКИ ТА НАПРЯМИ ПОДАЛЬШИХ ДОСЛІДЖЕНЬ}

Таким чином, позитивного ефекту від цифровізації економіки не доведеться довго чекати. Відмовляючись від паперових процесів та цифровізуючи складові елементи своєї роботи, суб'єкти господарювання зможуть зменшити кількість кроків, раніше необхідних для функціонування, поліпшити терміни виконання робіт, значно підвищити ефективність своєї діяльності та, в кінцевому підсумку, знизити експлуатаційні витрати. Цифровізація економіки допоможе суспільству створити надійне цифрове середовище, оптимізувати та масштабувати операції, зробити їх послідовними та безпечними.

За рахунок цифровізації стає можливим прискорено розвивати інновації, підтримувати стартапи, навчати всіх бажаючих основам програмування, впроваджувати цифрові технології у галузі економіки. Реалізація всіх вищеперелічених умов дозволить підвищити продуктивність функціонування всієї економічної системи держави та отримати додаткові конкурентні переваги у глобалізованому цифровому світі.

\section{Мітература:}

1. Про схвалення Концепції розвитку цифрової економіки та суспільства України на 2018-2020 роки та затвердження плану заходів щодо їі реалізації : Розпорядження КМУ від 17 січня 2018 р. № 67-р. - Режим доступу: http://zakon.rada.gov.ua/laws/show/67-2018$\% \mathrm{D} 1 \% 80$

2. Цифрова адженда України - 2020 ("Цифровий порядок денний" - 2020) Концептуальні засади (версія 1.0) Першочергові сфери, ініціативи, проекти "цифровізації" України до 2020 року [Електронний ресурс]. К.: ГС "Хай-тек офіс Україна", 2016. - 90 с. - Режим доступу: https://ucci.org.ua/uploads/files/58e78ee3c3922.pdf

3. Карчева Г.Т. Цифрова економіка та її вплив на розвиток національної та міжнародної економіки / Г.Т. Карчева, А.В. Огородня, В.А. Опенька // Фінансовий простір. - 2017. - № 3 (27). - С. 13-21.

4. Коляденко С.В. Цифрова економіка: передумови та етапи становлення в Україні і у світі / С.В. Коляденко // Економіка. Фінанси. Менеджмент. - 2016. № 6. - C. $105-112$.

5. Краус Н.М. Цифрова економіка: тренди та перспективи авангардного характеру розвитку [Електронний ресурс]/ Н.М. Краус, О.П. Голобородько, К.М. Краус // Ефективна економіка. - 2018. - № 1. - Режим доступу : http://www.economy.nayka.com.ua /pdf/1_2018/8.pdf

6. Фіщук В. Цифрова економіка - це реально [Електронний ресурс]/В. Фіщук. - Режим доступу: http: // biz.nv.ua ukr

7. Юдина Т.Н. Цифровая экономика сквозь призму философии хозяйства и политической экономии / Т.Н. Юдина, И.М. Тушканов // Философия хозяйства.2017. — № 1. — C. 193-201.

8. Аяшенко B.I. Цифрова модернізація економіки України як можливість проривного розвитку: монографія / В.І. Аяшенко, О.С. Вишневський; НАН України, Ін-т економіки пром-сті. - K., 2018. - 252 с.

9. Clarck C. Conditions of economic progress. 3-d ed./ C. Clarck. - London: The Macmillian Co. - New York: St. Martin's press, 1957. - $236 \mathrm{p}$.

10. Jason Bloomberg. Digitization, Digitalization, And Digital Transformation: Confuse Them At Your Peril. Retrieved from: https://www.forbes.com/sites/ jasonbloomberg/2018/04/29/digitization-digitalizationand-digital-transformation-confuse-them-at-your-peril/ \#1e1fe3d02f2c

11. Mehdi Khosrow-Pour. Encyclopedia of Information Science and Technology, Fourth Edition (10 Volumes). IGI Global, June, 2017. - 8104 p.
12. Белевцев А. Цифровизация - это фундаментальный тренд/ А. Белевцев / / Сибирская нефть.-2018. № 7/154. - C. $20-36$.

13. Schrage M. (2016, April 11). Rethinking the Value of Customers in a Digital Economy. Retrieved from: http:/ /sloanreview.mit.edu/article/rethinking-thevalue-ofcustomers-in-a-digital-economy

14. Colin N. The digital economy / N. Colin, A. Landier, P. Mohnen, A. Perrot. - 2015. - № 26. p. 1-12. Retrieved from: https://www.cairn-int.info/article-E_NCAE_026_0001--the-digital-economy.htm

\section{References:}

1. Cabinet of Ministers of Ukraine (2018), "About the conceptualization of the development of the digital economy for Ukraine and Ukraine for 2018-2020 and the hardening of the plan for entry into the project", available at: http://zakon.rada.gov.ua/laws/show/67-2018-\%D1\%80 (Accessed 05 Nov 2018).

2. High-Tech Office Ukraine (2016), "Digital Adzhda of Ukraine - 2020. Conceptual foundations. Priority areas, initiatives, projects of "digitalization" of Ukraine by 2020", available at: https://ucci.org.ua/uploads/files/58e78ee3c3922.pdf (Accessed 05 Nov 2018).

3. Karcheva, G.T. Ogorodnya, D.V. and Open'ka, V.A (2017), "The digital economy and its impact on the development of national and international economics", Finansovyy prostir, vol. 3 , pp. 13-21.

4. Kolyadenko, S.V. (2016), "Digital economy: preconditions and stages of formation in Ukraine and in the world", Ekonomika. Finansy. Menedzhment, vol. 6, pp. $105-112$.

5. Kraus, N.M. Holoborod'ko, O.P. and Kraus, K.M. (2018), "Digital economy: trends and prospects for the avant-garde nature of development", Efektyvna ekonomika, vol. 1, available at: http://www.economy.nayka.com.ua pdf/1_2018/8.pdf (Accessed 05 Nov 2018).

6. Fishchuk, V. (2017), "Digital economy is real", available at: http:// biz.nv.ua/ukr (Accessed 05 Nov 2018).

7. Yudina, T.N. and Tushkanov, I.M. (2017), "Digital economy through the prism of economic philosophy and political economy", Filosofiya khozyaystva, vol. 1, pp. 193201.

8. Lyashenko, V.I. and Vyshnevs'kyy, O.S. (2018), Tsyfrova modernizatsiya ekonomiky Ukrayiny yak mozhlyvist' proryvnoho rozvytku: monohrafiya [Digital modernization of the Ukrainian economy as a possibility of breakthrough development: monograph], NAN Ukrayiny, In-t ekonomiky prom-sti, Kyiv, Ukraine.

9. Clarck, C. (1957), Conditions of economic progress, The Macmillian Co, London, Great Britain, St. Martin's press New York, USA.

10. Bloomberg, J. (2018), "Digitization, Digitalization, And Digital Transformation: Confuse Them At Your Peril", available at: https://www.forbes.com/sites/jasonbloomberg/2018/04/29/digitization-digitalization-and-digitaltransformation-confuse-them-at-your-peril/\#1e1fe3d02f2c (Accessed 05 Nov 2018).

11. Khosrow-Pour, M. (2017), Encyclopedia of Information Science and Technology, Fourth Edition (10 Volumes), IGI Global, Hershey PA, USA.

12. Belevtsev, A. (2018), "Digitalization is a fundamental trend", Sibirskaya neft', vol. 7/154, pp. 20-36.

13. Schrage, M. (2016), "Rethinking the Value of Customers in a Digital Economy", available at: http:// sloanreview.mit.edu/article/rethinking-thevalue-ofcustomers-in-a-digital-economy (Accessed 05 Nov 2018).

14. Colin, N. Landier, A. Mohnen, P. and Perrot, A. (2015), "The digital economy", vol. 26, pp. 1-12, available at: https://www.cairn-int.info/article-E_NCAE_026_0001-the-digital-economy.htm (Accessed $0 \overline{5}$ Nov 2018).

Стаття надійшла до редакиіï 10.11.2018 p. 
УАK 311.21:[330.3:614.2]

Ю. О. Аазебник,

к.е.н., доцент, доцент кафедри статистики, обліку та аудиту,

Харківсъкий начіональний університет імені В.Н. Каразіна, м. Харків

DOI: $10.32702 / 2306-6806.2018 .11 .66$

\section{МОНІТОРИНГ ЯКОСТІ ЗАЙНЯТОСТІ В УКРАЇНІ: ЗАПРОВААЖЕННЯ ЄВРОПЕЙСЬКОЇ СИСТЕМИ ОБСТЕЖЕННЯ УМОВ ПРАЦІ}

Iu. Lazebnik,

PhD, Associate Professor, Associate Professor of Statistics, Accounting and Auditing Department, V.N. Karazin Kharkiv National University

MONITORING OF THE QUALITY OF EMPLOYMENT IN UKRAINE: ESTABLISHMENT OF EUROPEAN SYSTEM OF WORKING CONDITIONS SURVEY

УСтатті розглядаються актуальні питання вивчення аспектів якості зайнятості. Метоюдослідження адаптація міжнародних підходів оцінювання якості зайнятості до національних умов. Розроблення методичного забезпечення проведення опитування щодо умов праці дАя Створення науково обгрунтованої бази удосконалення територіальних та місцевих програм зайнятості населення в Україні.

УСтатті визначено основні стратегічні напрями дАя проведення заходів, спрямованих на забезпечення знань і умінь для досягнення поглибленого уявлення про умови життя та праці, що були запропоновані Свропейським фондом поліпшення умов життя та праці (Еuгоfound). Розглянуто останні загальноєвропейські обстеження, проведені Свропейським фондом, що спрямовані на збір якісної інформації про Умови життя, праці та практику роботи. ВикАадено методологічні засади забезпечення якості опитувань.

Розкрито особливості формування шести хвиль Свропейського опитування щодо умов праці та якості зайнятості (EWCS) в країнах Свропи у 1990-2015 рр. Визначено основні завдання і мета ЕWCS-2015. Розкрито основні теми, що на сьогодні охоплені обстеженням умов праці ЕWCS.

Особливу увагу приділено обгрунтуванню необхідності та розробленню методологічних засад проведення аналогічного анкетування в Україні на основі адаптованої,до національних умов анкети для оцінювання умов праці. Наведено структуру адаптованої версії анкети за розділами та підрозділами і наведено прикдади питань за кількома підрозділами.

The article deals with topical issues of studying aspects of the quality of employment. The aim of the study is to adapt international approaches to assessing the quality of employment to national conditions. Development of methodological support for conducting a survey on working conditions for the creation of a scientifically sound basis for improving the territorial and local employment programs of the population in Ukraine.

The article outlines the main strategic directions for activities aimed at providing knowledge and skills for an in-depth understanding of living and working conditions proposed by the European Foundation for the Improvement of Living and Working Conditions (Eurofound). The latest European-wide surveys conducted by the Eurofound, aimed at collecting quality information on living conditions, work and work practices, are considered. The methodological bases of quality assurance of polls are outlined. The basic requirements for developing a high-quality questionnaire as a key element of a successful survey are defined.

The peculiarities of the formation of the six waves of the European Working Conditions Survey (EWCS) in European Countries in 1990-2015 have been identified. The main objectives and objectives of the European Labor Survey EWCS-2015, which is to systematize certain aspects of employee experience, identify their main directions. The main topics covered by the EWCS Labor Inspection are discussed.

Particular attention is paid to substantiation of necessity and development of methodological principles of holding a similar questionnaire in Ukraine on the basis of an adapted to national conditions questionnaire for the evaluation of working conditions. The structure of the adapted version of the questionnaire by sections and subdivisions is given and examples of questions are given in several units. To illustrate the results of the European survey, the percentage of workers who responded "No" to the question "Does your work affect your health?" Is given by the countries that participated in the survey. The main advantages and disadvantages of the EWCS survey are identified. 
The prospects for further exploration, which should be aimed at a detailed study of such aspects of employment quality as employment-related relationships, labor motivation, safety and ethics of employment, the length of working time and the combination of work and personal life, as well as the development of appropriate a set of statistical indicators, the formation of an information base for research and evaluation of the quality of employment in the territorial communities of Ukraine.

Ключові слова: якість зайнятості, умови прачі, анкетування, Европейсвке обстеження умов прачі (EWCS), Европейський фонд поліпшення умов життя та прачі (Еврофонд).

Key words: quality of employment, working conditions, questionnaires, European Working Conditions Survey (EWCS), European Foundation for the Improvement of Living and Working Conditions (Eurofound).

\section{ПОСТАНОВКА ПРОБЛЕМИ}

Сучасна концепція якості зайнятості спирається на визначення зайнятості, схвалене в Резолюції про статистику праці, зайнятості та недовикористання робочої сили, що прийнята на 19-й Міжнародній конференції статистиків праці, що відбулася в жовтні 2013 року [13]. Ця Резолюція містить не тільки уточнення до існуючих стандартів Міжнародної конференції статистиків праці (МКСП), що стосуються концептуальних визначень і керівних принципів щодо робочої сили і суміжних компонентів, але також й нові основи і керівні принципи для вимірювання різних форм трудової діяльності і рекомендації щодо показників недовикористання робочої сили.

\section{АНАЛІЗ ОСТАННІХ ДОСЛІДЖЕНЬ І ПУБЛІКАЦІЙ}

Проблеми зайнятості населення України, зокрема ефективності та продуктивності зайнятості та умов праці, досліджували такі вітчизняні науковці: Коваль С.П., Киричук I.M., Кісельова O.О., Онікієнко В.В., Коваленко H.I., Пасєка C.P., Штундер I.О. та ін. [2-7].

Мало дослідженим залишається такий надзвичайно важливий аспект, як якість зайнятості. Важливість якості зайнятості в рамках своєї роботи підкреслюють багато міжнародних організацій, особливо Міжнародна організація праці (МОП) та Європейський фонд поліпшення умов життя і праці - Еврофонд (European Foundation for the Improvement of Living and Working Conditions) [8].

\section{ПОСТАНОВКА ЗАВДАННЯ}

Метою дослідження є адаптація міжнародних підходів оцінювання якості зайнятості до національних умов. Розроблення методичного забезпечення проведення опитування щодо умов праці для створення науково обгрунтованої бази удосконалення територіальних та місцевих програм зайнятості населення в Україні.

\section{ВИКЛАДЕННЯ ОСНОВНОГО МАТЕРІАЛУ}

Провідною організацією, яка приділяє особливу увагу дослідженню умов праці та якості зайнятості є Європейський фонд поліпшення умов життя та праці (European Foundation for the Improvement of Living and Working Conditions - Eurofound) [8], який є тристоронньою агенцією Європейського Союзу.

Аослідження, що здійснює Eurofound, спрямовані на підтримку цілей стратегії "Европа 2020" [12], розроблення науково обгрунтованих, неупереджених, своєчасних та значущих даних, які сприяють більш обгрунтованій політиці зближення умов життя та праці в Європі, забезпечення розумного, сталого та всеохоплюючого розвитку європейських країн. Виконуючи дослідження, в ході якого узагальнюється та аналізується практичний досвід та визначаються чинники для успішних змін, Eurofound прагне документувати і розуміти зміни та розробляти ідеї щодо постійного покращення умов праці та життя європейських громадян.
Eurofound вибрав шість стратегічних напрямків для проведення заходів, спрямованих на забезпечення знань і умінь для досягнення поглибленого уявлення про умови життя та праці в Європейському Союзі:

- умови праці та сталість зайнятості;

- економічні відносини;

- зміни на ринку праці;

— якість життя та суспільні послуги;

- цифрова ера: можливості та проблеми праці та зайнятості;

- моніторинг конвергенції в Европейському Союзі.

За допомогою цих шести тем Eurofound вивчає як можна покращити умови життя та праці через державну політику та законодавство, втручання соціальних партнерів та практику на рівні робочих місць. У багаторічній програмі 2017-2020 років визначена конкретна робоча програма для кожного року програмного пеpiozy.

Перші чотири теми є основними напрямами, де Eurofound має значний досвід проведення досліджень протягом чотирьох десятиліть та забезпечує безперервність роботи Агенції. Останні два (цифрова ера та конвергенція в ЄC) вносять новий вимір у діяльність Eurofound, оскільки вони відображають наскрізні проблеми та парадигматичні зміни, які, ймовірно, матимуть трансформаційний вплив на центральні сфери досліАжень Eurofound.

Кожне загальноєвропейське обстеження, проведене Eurofound, спрямоване на населення країни, щоб збирати якісну інформацію про умови життя, праці та практику роботи. Серед обстежень можна виділити наступні:

- Европейське обстеження умов праці (European Working Conditions Survey - EWCS) - це опитування працівників, спрямоване на отримання розуміння якості роботи та зайнятості;

- Европейське обстеження компаній (European Company Survey - ECS) - це обстеження, спрямоване на керівників та представників працівників компаній для збору інформації щодо практичних питань роботи;

- Европейське обстеження якості життя (European Quality of Life Survey - EQLS) — це інтерв'ю з людьми, спрямоване на умови життя та уявлення про якість життя.

Незважаючи на відмінності цільової аудиторії, Eurofound прагне узгодити методологію опитування, коли це можливо, щоб забезпечити порівнянність та співставність інформації, отриманої в ході певного опитування, для можливості їі застосування в інших сфеpax.

Як і у всіх дослідницьких проектах, зацікавлені сторони Eurofound та експерти у відповідній галузі беруть участь у розробці, впровадженні та оцінці кожного опитування, забезпечуючи їх відповідність європейським та національним політикам.

Залучивши експертів до розробки анкет, а також експертів на національному рівні у процес перекладу, Eurofound має на меті забезпечити, щоб всі питання опи- 
Таблиця 1. Хвилі опитування зайнятих EWCS щодо умов праці та якості зайнятості в країнах Європи у 1990-2015 рр.

\begin{tabular}{|c|c|c|}
\hline $\begin{array}{c}\text { Хвилі } \\
\text { опитування }\end{array}$ & $\begin{array}{c}\text { Роки } \\
\text { опитування }\end{array}$ & Країни, які приймали участь в опитуванні \\
\hline Перша & $1990-1991$ & $\begin{array}{l}\text { СС-12 (Бельгія, Велика Британія, Греція, } \\
\text { Данія, Ірландія, Іспанія, Італія, Люксембург, } \\
\text { Нідерланди, Німеччина, Португалія, } \\
\text { Франція) }\end{array}$ \\
\hline Друга & $1995-1996$ & $\begin{array}{l}\text { ЄС-15 (країни ЕС-12 плюс Австрія, } \\
\text { Фінляндія, Швеція) }\end{array}$ \\
\hline \multirow[t]{3}{*}{ Третя } & 2000 & 15 країн СС та Норвегія \\
\hline & 2001 & $\begin{array}{l}\text { обстеження поширено на } 12 \text { «нових» } \\
\text { держав-членів (Болгарія, Естонія, Кіпр, } \\
\text { Латвія, Литва, Мальта, Польща, Румунія, } \\
\text { Словаччина, Словенія, Угорщина, Чехія) }\end{array}$ \\
\hline & 2002 & обстеження поширено на Туреччину \\
\hline Четверта & 2005 & $\begin{array}{l}\text { ЄС-27, а також Норвегія, Хорватія, } \\
\text { Туреччина та Швейцарія }\end{array}$ \\
\hline П'ята & 2010 & $\begin{array}{l}\text { ЄС-27, а також Норвегія, Хорватія, колишня } \\
\text { Югославська Республіка Македонія, } \\
\text { Туреччина, Албанія, Чорногорія та Косово }\end{array}$ \\
\hline Шоста & 2015 & $\begin{array}{l}\text { ЄС-28, а також Норвегія, Швейцарія, } \\
\text { Албанія, колишня Югославська Республіка } \\
\text { Македонія, Чорногорія, Сербія та Туреччина }\end{array}$ \\
\hline
\end{tabular}

Ажерело: узагальнено автором за [8].

тування реально відображали явища, які вони мають намір охопити.

Важливо також забезпечити узгодженість результатів опитування. Eurofound це робить, відповідально підходячи до репрезентативності відбору, вибираючи найбільш підходящий спосіб адміністрування анкет, використовуючи найсучасніші технології, набираючи досвідчених інтерв'юерів та забезпечуючи всебічну підготовку для інтерв'ювання та кодування, а також шляхом миттєвої перевірки зібраних даних, застосовуючи складні ваги та відповідний аналіз.

Зобов'язання компанії Eurofound щодо надання високоякісної інформації також відображені у стратегії забезпечення якості опитувань.

Eurofound прагне до використання системи відбору одиниць Аля опитування (респондентів) найвищої якості. У кожній країні вона намагається знайти реєстр, який охоплює щонайменше $95 \%$ цільового населення. Аля об'єктної системи зберігання даних ECS (Entity Component System) краще, щоб ці реєстри містили контактну інформацію для установ, в іншому випадку використовуються бази даних компаній. Аля європейського опитування якості життя (EQLS) та європейського опитування умов праці (EWCS), реєстри зазвичай містять адреси домашніх господарств або окремих осіб [9; 10]. Коли такого реєстру немає, Eurofound використовує так звану процедуру "випадковий маршрут" для створення списку можливих респондентів.

Eurofound також має намір відібрати вибірки, якіє достатньо великими, щоб отримати дійсні результати на рівні окремих країн, які відображають розподіл європейського населення належним чином для того, щоб узагальнити в Європі у цілому.

Мета дослідження вимагає, щоб розмір вибірки на рівні країни становив принаймні 1000 респондентів, для зменшення похибки обстеження. Аруга мета - відбір великої кількості об'єктів у великих країнах, як це робиться в останніх EWCS та EQLS.

Іноді доводиться задавати відкриті запитання, які не входять у список заздалегідь визначених відповідей. Це може бути, наприклад, для сектору. Інтерв'юер спочатку отримає детальну відповідь, а потім включить її до відповідної категорії в загальноєвропейській статистичній класифікації економічної діяльності (NACE).

Кодування, як правило, повинно застосовуватися для відкритих питань, пов'язаних із доходом, рівнем освіти респондентів (через ISCED), а також регіоном, в якому вони живуть (через NUTS).
Коли фаза збору даних завершена, набори даних зважуються, щоб компенсувати різні можливі причини дисбалансу у вибірці. Той факт, що різні люди мають різну ймовірність відбору для опитування, має бути враховано статистично. Чим більша кількість людей, які живуть або працюють, тим менша їхня можливість узяти участь в інтерв'ю. Також варіація рівня готовності брати участь в опитуванні може призвести до недостатньої представленості окремих груп респондентів. Відмінності у розмірі робочої сили в різних країнах не повністю відображаються у національних вибірках. Отже, зважування гарантує, що великі країни більше впливають на результати на рівні ЄС.

Европейське опитування робочої сили (The European Labour Force Survey - LFS) часто використовується як джерело довідкових даних для визначення того, наскільки дані є репрезентативними для населення.

Eurofound адаптує методологію до конкретних вимог кожного опитування. Більш детальна інформація доступна на окремих сторінках опитування [9; 10$]$.

3 моменту свого заснування у 1990 році Європейське опитування умов праці (EWCS) надає огляд умов праці в Європі, з тим щоб:

- визначати та кількісно оцінювати на гармонізованій основі умови праці як найманих працівників у Европі, так і самозайнятих; праці;

- аналізувати зв'язки між різними аспектами умов

- визначати групи ризику та актуальні питання;

- здійснювати моніторинг тенденції шляхом надання однорідних та зіставних у часі показників 3 цих питань;

- сприяти розвитку європейської політики, зокрема, у сфері якості праці та зайнятості.

ЄС охоплює різноманітні системи виробничих відносин, які розвиваються у відповідь на політичні та економічні події та змінюються 3 плином часу. На цьому тлі Eurofound створив інструмент для систематичного моніторингу та аналізу того, як європейські системи економічних відносин адаптуються до посткризових часів та еволюціонують. Цей інструмент передбачає проведення анкетування, яке базується на чотирьох ключових вимірах промислових відносин: промислової демократії, конкурентоспроможності промисловості, соціальної справедливості та якості праці й зайнятості.

Працівники були випадково вибрані зі статистичної вибірки, що складається з усіх шарів суспільства. Залежно від розміру країни та національних домовленостей вибірка становила від 1000 до 3300 осіб на одну країну. 
РОЗДІЛ. 1. ЗАГАЛЬНІ ДАНІ ПРО ЧЛЕНІВ ДОМОГОСПОДАРСТВА

1.1. Дані про респондента 1.2. Дані про інших членів домогосподарства

РОЗДІЛ 2. ОСНОВНА ЧАСТИНА

2.1. Основні питання про роботу

2.2. Питання, що стосуються компанії або організації, яка є основним місцем роботи

2.3. Питання, що стосуються приватного бізнесу

2.4. Питання щодо основної оплачуваної роботи

2.5. Питання стосовно рівноваги між роботою та особистим життям

2.6. Питання стосовно того, як організована робота

2.7. Питання щодо безпосереднього начальника

2.8. Питання про навички і навчання

2.9. Питання, присвячені здоров'ю

2.10. Питання про час відсутності на роботі останнім часом

2.11. Питання, що стосуються роботи в цілому

2.12. Питання, що стосуються діяльності поза робочим часом

2.13. Питання, що стосуються освіти і доходу

Рис. 1. Структура адаптованої версії анкети для оцінювання умов праці

Ажерело: розроблено автором.

Особисте інтерв'ю проводилося в будинках людей і охоплювало вичерпний перелік питань щодо їх умов праці. Уся зібрана інформація була розглянута з гарантованою конфіденційністю та анонімністю кожного інтерв'юера.

Високоякісна анкета є ключовим елементом успішного опитування: Eurofound вкладає значні кошти у розробку та якісний переклад анкет. Кожного разу, коли проводяться EWCS, анкета переглядається за підтримки експертів, політичних діячів та керівництва Eurofound.

У кожній хвилі опитувань випадкова вибірка працівників (робітників та самозайнятих) була обстежена із використанням особистого анкетування. Після розширення Європейського Союзу та інтересів з країн Європейської асоціації вільної торгівлі (ЕАВТ, англ. European Free Trade Association - EFTA) географічне покриття опитування розширилося (табл. 1).

Шоста хвиля опитування EWCS включає питання попередніх опитувань, що дозволяють проводити аналіз 3 плином часу. Вона також містить нові запитання, що стосуються виникаючих професійних та політичних проблем, що представляють інтерес. 3 метою забезпечення повної картини якості зайнятості чоловіків і жінок 3 моменту проведення першої хвилі опитування перелік запитань анкети значно розширився. Врахування гендерної проблематики є важливим аспектом для розроблення останніх варіантів анкети.

Останнє опитування EWCS відбулося у 2015 році. Анкета була підготовлена на тридцяти двох різних мовах, одинадцять 3 яких були використані в більш ніж одній країні та, при необхідності, адаптовані до культурного контексту. Всі мовні версії доступні на веб-сайті Еврофонда [14].

Метою EWCS є систематизація певних аспектів досвіду працівників. Вона включає в себе такі напрями:

- фізичні та психосоціальні фактори ризику;

- робочий час: тривалість, організація, передбачуваність та гнучкість; робочий і життєвий баланс;

- місце роботи;

- швидкість роботи, детермінанти темпу;

- участь працівників, політика щодо кадрових ресурсів та організація роботи (наприклад, обертання завдань); представництво працівників;
- використання навичок, пізнавальні аспекти роботи, прийняття рішень та навчання у роботі;

- умови праці: безпека роботи та незахищеність;

- соціальні відносини на роботі: підтримка, довіра, співпраця, дискримінація, насильство;

- гендерні питання: сегрегація, склад сім'ї, неоплачувана робота, розмір жінок на контрольних посадах; пека.

- добробут та здоров'я, заробіток та фінансова без-

Аоступні мовні версії, що використовуються в кожній країні, також охоплені EWCS.

Теми, що на сьогодні охоплені обстеженням EWCS, включають:

- статус зайнятості;

- тривалість та організацію робочого часу;

— організацію праці;

- навчання та підготовку;

- фактори фізичного та психосоціального ризику;

— охорону здоров'я та безпеку;

- баланс праці та особистого життя;

- участь працівників;

- прибуток та фінансову безпеку;

- роботу та здоров'я.

В Україні доцільно започаткувати проведення аналогічного анкетування на основі адаптованої до національних умов анкети.

Адаптована версія анкети включає такі розділи та підрозділи (рис. 1).

Питання підрозділу "Питання стосовно рівноваги між роботою та особистим жкиттям" вкючають, зокрема, такі:

Q44. Як графік вашої роботи дозволяє виконувати свої сімейні обов'язки, а також займатися громадською діяльністю поза робочим місцем?

Q46. Як часто за останні 12 місяців (або з тих пір, як ви почали працювати на вашій основній оплачуваній роботі) траплялося, що ви працювали в свій вільний час, щоб виконати робочі вимоги?

Ао питань підрозділу "Питання стосовно того, як організована робота", зокрема, входять такі:

Q48. Чи характерні для вашої роботи короткі повторювані робочі завдання, що тривають менше: 1 хвилини, 10 хвилин? 


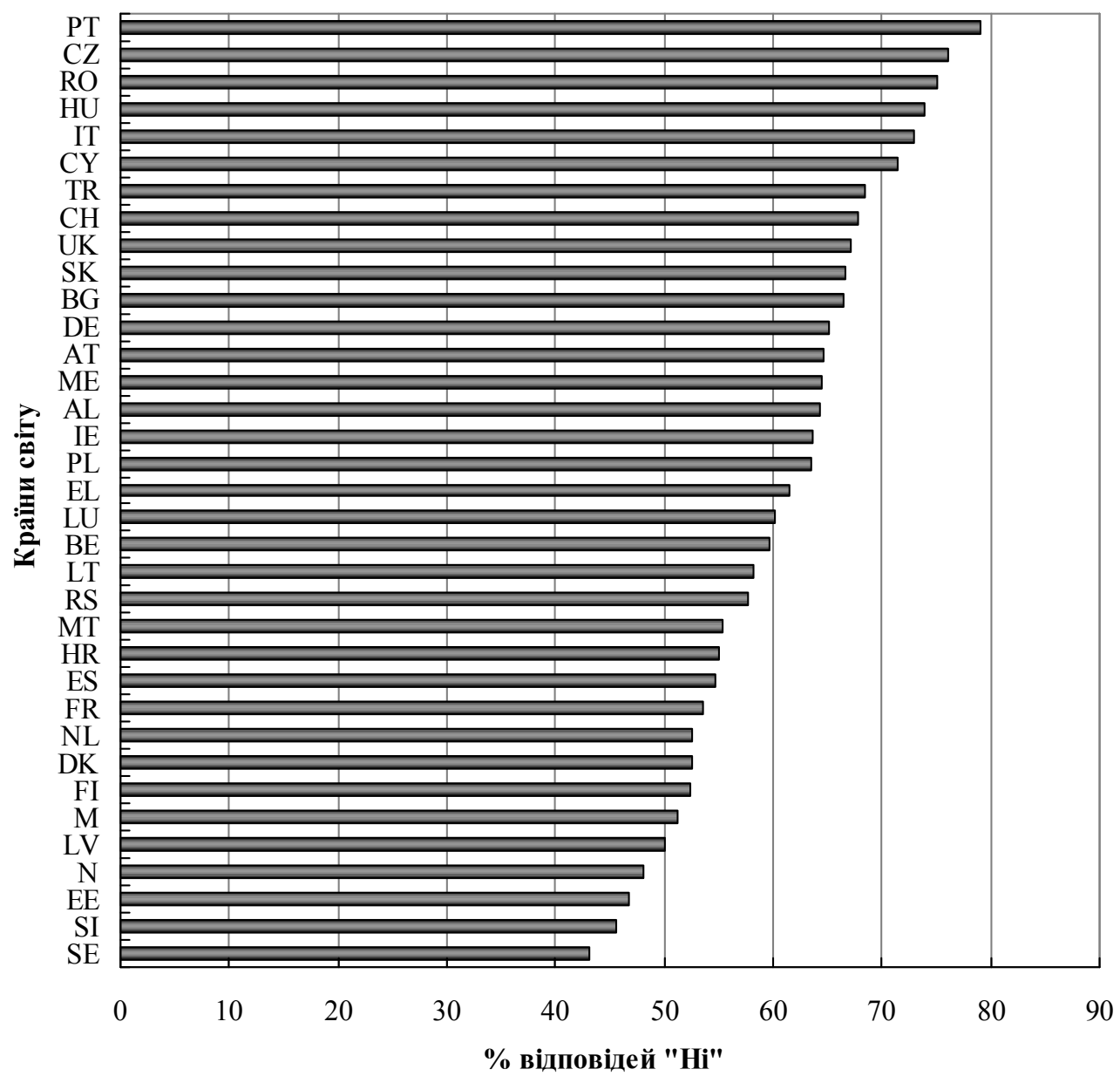

Рис. 2. Структура відповідей "Ні" респондентів на питання "Чи ваша робота впливає на ваше здоров'я?" за країнами світу, що брали участь у опитуванні в 2015 р.

Ажерело: за даними [11].

Q51. Як часто вам доводиться переривати свою роботу, щоб зайнятися непередбаченими дорученнями?

Q55. Чи потребує ваша робота обміну 3 колегами своїми робочими завданнями? ня?

Q57. Хто вирішує, як розподіляти ці робочі завдан-

Блок питань підрозділу "Питання, присвячені здоров'ю" містить такі питання:

Q73. Як ви вважаєте, ваші здоров'я або безпека схильні до ризику через роботу?

Q74. Чи впливає ваша робота на ваше здоров'я?

Q75. Який загальний стан вашого здоров'я?

Q76. Чи є у вас яке-небудь захворювання або проблема зі здоров'ям, які вже тривають більше 6 місяців?

Q77. Чи обмежені ваші повсякденні дії через це захворювання або проблеми зі здоров'ям?

Питання підрозділу "Питання про час, коли ви могли бути відсутніми на роботі останнім часом" включають, зокрема такі:

Q82. Скільки днів за останні 12 місяців (або з тих пір, як ви почали працювати на вашій основній оплачуваній роботі) ви були відсутні на роботі через перебування на лікарняному або у відпустці через хворобу?

Q83.а. Скільки з цих днів на лікарняному були результатом нещасних випадків на роботі?

Q83.b. Скільки з цих днів на лікарняному були результатом проблем зі здоров'ям, які були викликані або посилилися через роботу (крім нещасних випадків)?

Q84.a. Чи працювали ви у той час, коли були хворі, за останні 12 місяців (або з тих пір, як ви почали працювати на своїй основній оплачуваній роботі)?

Q86. Чи необхідні в майбутньому зміни на вашому робочому місці або у вашій трудовій діяльності з тим, щоб ви могли до них пристосуватися з урахуванням своєї хвороби або проблеми зі здоров'ям?

Наприкінці анкети розміщено окремий розділ "Протокол інтерв'юера", де вказуються: дата опитування; час початку опитування; час закінчення опитування; регіон України; кількість осіб, присутніх на опитуванні, включаючи інтерв'юера; чи були потрібні респонденту роз'яснення; чи виникали у нього труднощі, відповідаючи на питання.

На основі розробленої анкети із використанням інструментарію Google-форми [1] проведено пробне опитування домогосподарств та окремих осіб України щодо якості зайнятості.

На рисунку 2 для ілюстрації результатів європейського опитування наведено частки працівників, які відповіли "Нi" на запитання "Чи ваша робота впливає на ваше здоров'я?" ("Does your work affect your health?"), за країнами, що брали участь в опитуванні [11].

На офіційному веб-сайті Єврофонда [11] є інструментарій географічної візуалізації результатів опитування за країнами ЕС, що брали участь в обстежені EWCS-2015, за кожним питанням анкети.

Так, за результатами опитування країнами 3 найбільшою часткою респондентів, що відповіли "Ні" на питання "Чи ваша робота впливає на ваше здоров'я?" виявилися Португалія, Чеська Республіка, Румунія, а 3 найменшою - Швеція, Словенія, Естонія.

\section{ВИСНОВКИ}

Перевага опитування EWCS полягає в тому, що воно пропонує детальні показники для вимірювання якості роботи на макрорівні (тобто рівні індивідуальних працівників), які можна агрегувати до національного рівня та дезагрегувати за групами працівників 
(тобто гендерна ознака, вид економічної діяльності тощо). Основним його недоліком є нерегулярність: опитування проводиться лише кожні п'ять років, деякі питання не зберігаються незмінними в наступних опитуваннях, для окремих країн існують невеликі вибіркові показники, а для деяких вимірів використовуються неповні показники. Крім того, заробітна плата не належним чином покрита (дані у багатьох країнах відсутні, або кількість вибірки замала для проведення змістовного аналізу).

Перспективи подальших розвідок. Питання статистичного оцінювання якості зайнятості є доволі широким та таким, що потребує комплексного вирішення. Подальші дослідження будуть спрямовані на детальне вивчення таких аспектів якості зайнятості, як відносини, пов'язані з зайнятістю, трудова мотивація, безпека й етика зайнятості, тривалість робочого часу і поєднання трудової діяльності та особистого життя, а також на розроблення відповідного набору статистичних показників, формування інформаційної бази дослідження та оцінювання якості зайнятості в територіальних громадах України.

\section{Мітература:}

1. AНКЕТА для оцінювання умов праці [Електронний ресурс]. Google-форма. - Режим доступу: https:// goo.gl/forms/JBiS1riBrzfgYNXB2

2. Коваль С.П. Соціально-економічні проблеми якості зайнятості населення на ринку праці України // Аспекти праці. - 2012. - № 2. - С. $20-25$.

3. Киричук I.M. Аослідження умов праці та особливостей організації лікувально-діагностичного процесу в інфекційних стаціонарах // Україна. Здоров'я нації, 2016. - № 1-2 (37-38). - C. 94-98.

4. Кісельова О.О. Забезпечення ефективної зайнятості населення в економіці регіону: автореферат дис. канд. екон. наук: 08.00.07 / Нац. акад. наук України, Ін-т екон.- правов. дослідж. - Аонецьк, 2009. - 20 с.

5. Онікієнко В.В. Коваленко Н.I. Продуктивна зайнятість: зміст, актуальні проблеми і шляхи досягнення. - К.: Прінт-експрес, 2008. - 50 с.

6. Пасєка С.Р. Ефективна зайнятість як форма реалізації соціально-трудового потенціалу // Науковий вісник ЧАIЕУ. Серія 1. Економіка: збірник наукових праць. - Чернігів: ЧАIEУ, 2012. — № 2 (14). - 200 с.

7. Штундер I.O. Механізм формування ефективної зайнятості в умовах інноваційного розвитку економіки // Соціально-трудові відносини: теорія та практика: зб. наук. пр. / М-во освіти і науки України, АВНЗ "Київ. нац. екон. ун-т ім. Вадима Гетьмана"; [редкол.: А.М. Колот (голова) та ін.]. - К.: КНЕУ, 2014. — № 2. - С. 162166.

8. European Foundation for the Improvement of Living and Working Conditions. Official Website [Electronic resource]. - Way of access: https://www.eurofound.europa.eu/

9. European Quality of Life Surveys (EQLS) [Electronic resource] / Eurofound. - Way of access: https:// www.eurofound.europa.eu/surveys/european-quality-oflife-surveys

10. European Working Conditions Surveys (EWCS) [Electronic resource]/ Eurofound. - Way of access: https:; www.eurofound.europa.eu/surveys/european-workingconditions-surveys

11. European Working Conditions Survey - Data visualization [Electronic resource]/ Eurofound. - Way of access : https://www.eurofound.europa.eu/data/europeanworking-conditions-survey

12. Europe 2020 strategy [Electronic resource]/ European Commission. - Way of access: https:// ec.europa.eu/info/business-economy-euro/economic-and-fiscalpolicy-coordination/eu-economic-governance-monitoring-prevention-correction/ european-semester/framework/europe-2020-strategy_en
13. Resolution concerning statistics of work, employment and labour underutilization (19th International Conference of Labour Statisticians, 2013) [Electronic resource] / International Labour Office, Department of Statistics. Geneva, ILO, 2013. - Way of access : http:/ www.ilo.org/wcmsp5/groups/public/---dgreports/---stat/ documents/normativeinstrument/wcms 230304.pdf

14. Sixth European Working Conditions Survey: 2015 [Electronic resource]/ Eurofound. - Way of access : https:/ www.eurofound.europa.eu/surveys/european-workingconditions-surveys/sixth-european-working-conditionssurvey-2015

\section{References:}

1. Google-form (2018), "Questionnaire for Evaluation of Working Conditions", available at: https://goo.gl/forms/ JBiS1riBrzfgYNXB2 (Accessed 24 Okt 2018).

2. Koval, S.P. (2012), "Socio-economic problems of the quality of employment of the population on the labor market of Ukraine", Aspekty pratsi, vol. 2, pp. 20-25.

3. Kyrychuk, I.M. (2016), "Investigation of working conditions and peculiarities of organization of medicaldiagnostic process in infectious hospitals", Ukraina. Zdorov'ia natsii, vol. 1-2 (37-38), pp. 94-98.

4. Kisel'ova, O.O. (2009), "Ensuring effective employment of the population in the region's economy", Ph.D. Thesis, 08.00.07, National Academy of Sciences of Ukraine, Institute of Economic and Legal Studies, Donetsk, Ukraine.

5. Onikiienko, V.V. and Kovalenko, N.I. (2008), Produktyvna zajniatist': zmist, aktual'ni problemy i shliakhy dosiahnennia [Productive employment: content, topical issues and ways to achieve], Print-ekspres, Kyiv, Ukraine.

6. Pasieka, S.R. (2012), "Effective employment as a form of social and labor potential implementation", Naukovyj visnyk ChDIEU. Seriia 1. Ekonomika: zbirnyk naukovykh prats', vol. 2 (14), p. 200

7. Shtunder, I.O. (2014), "Mechanism of formation of effective employment in conditions of innovative development of economy", Sotsial'no-trudovi vidnosyny: teoriia ta praktyka, vol. 2, pp. 162-166.

8. The official site of European Foundation for the Improvement of Living and Working Conditions (2018), available at: https://www.eurofound.europa.eu/ (Accessed 24 Okt 2018).

9. Eurofound (2018), "European Quality of Life Surveys (EQLS)", available at: https://www.eurofound.europa.eu/ surveys/ european-quality-of-life-surveys (Accessed 24Okt 2018).

10. Eurofound (2018), "European Working Conditions Surveys (EWCS)", available at: https://www.eurofound.europa.eu/surveys/ european-working-conditionssurveys (Accessed 24 Okt 2018).

11. Eurofound (2018), "European Working Conditions Survey - Data visualization", available at: https:// www.eurofound.europa.eu/data/european-workingconditions-survey (Accessed 24 Okt 2018).

12. European Commission (2018), "Europe 2020 strategy", available at: https://ec.europa.eu/info/businesseconomy-euro/economic-and-fiscal-policy-coordination/ eu-economic-governance-monitoring-preventioncorrection/ european-semester/framework/ europe-2020strategy_en (Accessed 24 Okt 2018).

13. International Labour Office, Department of Statistics (2013), "Resolution concerning statistics of work, employment and labour underutilization (19th International Conference of Labour Statisticians)", available at: http:// www.ilo.org/wcmsp5/groups/public/---dgreports/---stat/ documents/normativeinstrument/wcms_230304.pdf (Accessed 24 Okt 2018).

14. Eurofound (2015), "Sixth European Working Conditions Survey: 2015", available at: https://www.eurofound.europa.eu/surveys/ european-working-conditionssurveys/sixth-european-working-conditions-survey-2015 (Accessed 24 Okt 2018).

Стаття надійшла до редакиії 12.11.2018 p. 
УAK 65.011:656.2

Н.Г. Панченко,

к.е.н., дочент, доцент кафедри економіки та управління виробничим і комерційним бізнесом,

Украӥнсъкий державний університет залізничного транспорту, м. Харків

\title{
МЕХАНІЗМ ФОРМУВАННЯ СТРАТЕГІЧНОГО ПАРТНЕРСТВА ЗА УЧАСТЮ ЗАЛІЗНИЧНОГО ТРАНСПОРТУ ТА МІЖНАРОАНИХ СТЕЙКХОААЕРІВ
}

\author{
N. Panchenko, \\ Candidate of Economic Sciences, Associate Professor, Associate Professor of the Department of Economics \\ and Management of Industrial and Commercial Business, Ukrainian State University of Railway Transport, Kharkiv
}

\section{MECHANISM FOR FORMING A STRATEGIC PARTNERSHIP INVOLVING RAIL TRANSPORT AND INTERNATIONAL STAKEHOLDERS}

\begin{abstract}
УСтатті,доведено, що вітчизняний залізничний транспорт,дотримуеться політики високої соціальної відповідальності не тільки перед своїми працівниками та їх близькими, а також перед населенням всіх регіонів, в Яких воно веде свою діяльність, і розглядає інвестування в соціальну сферу як найважливіший елемент Сталого розвитку регіонів, а також й всієї,ержави. ВСтановлено, що У діловій практиці та під чаС реалізації положень КСВ Убільшості корпорацій розвинених країн Світу неодмінною умовою успішного розвитку бізнесу вважають активну, відповідальну і продуктивнУ взаємодію з усіма зацікавленими Сторонами. ОАним 3 КАючових завдань у сфері роботи із взаємодї зі Стейкхолдерами ПАТ "УкраїнСька залізниця" є налагодження взаємовигідної продуктивної взаємодії з групами вітчизняних та міжнародних зацікавлених Сторін, що стане в подальшому основою для розвитку корпоративної соціальної відповідальності. В результаті аналізу особливостей господарювання залізничного транСпортУ, взаємодї його зі стейкхолдерами та виконання положень корпоративної соціальної відповідальності запропоновано організаційно-економічний механізм формування міжнародного стратегічного партнерства за участю залізничного транспорту, що на відміну ві, інших,доповнено Системою принципів, виділеними кАючовими групами міжнародних стейкходдерів та напрямами їх взаємодї̈.
\end{abstract}

The article shows that domestic rail transport adheres to a policy of high social responsibility not only to its employees and their relatives, but also to the population of all regions in which it operates, and considers investing in the social sphere as an essential element of the sustainable development of the regions, and also the whole state.

It is established that in business practice and during implementation of the provisions of CSR, in most corporations of developed countries, an essential condition for successful business development is considered to be active, responsible and productive interaction with all interested parties.

One of the key tasks in cooperation with stakeholders of PJSC "Ukrainian Railways" is to establish mutually beneficial productive interaction with groups of domestic and international stakeholders, which will become the basis for the development of corporate social responsibility in the future.

The following groups of international stakeholders were selected to form strategic partnerships: International Educational and Educational Programs, International Environmental Subjects, Railway Transport Investment Companies, International Organizations for Infrastructure Activities of Railway Transport. When forming the partnership lines, it should be borne in mind that globalization and the economics of foreign policy are expanding the range of goals of international strategic relations, using new methods of its application for this purpose. 
As a result of the analysis of the characteristics of railway management, its interaction with stakeholders and implementation of corporate social responsibility, an organizational and economic mechanism for the formation of an international strategic partnership with the participation of rail transport has been proposed, which, unlike the others, is supplemented by a system of principles, selected by the key international stakeholdergroups and their interactions.

Ключові слова: залізничний транспорт, управління, міжнародні стейкхолдери, стратегічне партнерство, корпоративна сочіальна відповідальність.

Key words: railway transport, governance, international stakebolders, strategic partnership, corporate social responsibility.

\section{ПОСТАНОВКА ПРОБЛЕМИ У ЗАГАЛЬНОМУ ВИГЛЯДІ ТА ІІІ ЗВ'ЯЗОК ІЗ ВАЖЛИВИМИ НАУКОВИМИ ЧИ ПРАКТИЧНИМИ ЗАВДАННЯМИ}

ПАТ "Українська залізниця" є невід'ємним елементом суспільного середовища, в рамках якої здійснюється його діяльність. Корпоративна соціальна відповідальність вітчизняних залізниць є важливою частиною міжнародної діяльності, а також взаємодії держави, бізнесу і суспільства.

ПАТ "Українська залізниця" дотримується політики високої соціальної відповідальності не тільки перед своїми працівниками та їх близькими родичами, а також перед населенням всіх регіонів, в яких воно веде свою діяльність, і розглядає інвестування в соціальну сферу як найважливіший елемент сталого розвитку регіонів, а також й всієї держави.

Вітчизняна залізнична компанія, будучи одним 3 найбільших роботодавців в Україні, усвідомлює свою відповідальність за забезпечення безпеки праці працівників, створення і збереження робочих місць.

Однак глобалізація економіки і становлення багатополярного світу істотно впливають на всі напрями господарювання залізничного транспорту, забезпечення ефективності його діяльності та розвиток корпоративної соціальної відповідальності, що в свою чергу вимагає пошуку нових методів корпоративного управління, які будуть сприяти розвитку корпоративної соціальної відповідальності за рахунок максимально дієвій адаптації галузі до умов функціонування.

\section{АНАЛІЗ ДОСЛІДЖЕНЬ І ПУБЛІКАЦІЙ}

На сьогодні дослідження теоретичних основ корпоративної соціальної відповідальності досить популярна. Аналіз теоретичних напрацювань 3 проблематики корпоративної соціальної відповідальності [1-3] свідчить про високу зацікавленість вчених даним питанням, особливу увагу приділено: сучасному стану корпоративної соціальної відповідальності, проблемам та перспективам розвитку корпоративної соціальної відповідальності, розробці методів і моделей управління корпоративною соціальною відповідальністю та ін.

Щодо дослідження положень корпоративної соціальної відповідальності залізничного транспорту України, особливостей взаємодії зі стейкхолдерами та розвитку залізничної галузі на основі міжнародного співробітництва також розповсбджені, їм присвячена ціла низка праць за авторством: В. Аиканя [4], I. Токмакової [5], В. Овчиннікової [6] та ін. Щодо аналізу робіт присвячених вирішенню проблем розвитку міжнародної співпраці залізничного транспорту [4-9], то тут більшість напрацювань присвячена питанням: сучасний стан залізничного транспорту України, проблеми та перспективи розвитку транспортної інфраструктури, формування міжнародних об'єднань за участю залізничного транспорту, забезпечення транзитної привабливості країни та ін.
Разом з тим необхідні нові пропозиції, щодо формування міжнародного стратегічного партнерства за участю залізничного транспорту, які б забезпечували розвиток корпоративної соціальної відповідальності.

\section{ПОСТАНОВКА ЗАВДАННЯ}

Метою статті $€$ формування механізму міжнародного стратегічного партнерства за участю залізничного транспорту, що на відміну від інших базуються на принципах стратегічного партнерства, які забезпечують розвиток корпоративної соціальної відповідальності.

\section{ВИКЛАД ОСНОВНОГО МАТЕРІАЛУ} ДОСЛІДЖЕННЯ

Сьогодні ПАТ "Українська залізниця" є найбільшою в Україні транспортною вертикально-інтегрованою компанією, що ефективно і якісно забезпечує потреби національної економіки і населення в транспортних послугах.

У діловій практиці більшості розвинених країн світу неодмінною умовою успішного розвитку бізнесу вважають активну, відповідальну і продуктивну взаємодію 3 усіма зацікавленими сторонами. Провідна роль у цьому процесі належить компаніям, чия діяльність має найбільш значущий вплив на суспільство і навколишнє середовище.

Виходячи з високої суспільної значимості діяльності та 3 метою реалізації своєї місії, ПАТ "Українська залізниця" здійснює широкий комплекс заходів соціального та екологічного характеру, спрямований, на розширення і підвищення ефективності взаємодії з усіма зацікавленими сторонами.

Однією $з$ ключових завдань у сфері роботи із взаємодії зі стейкхолдерами компанії є налагодження взаємовигідної продуктивної взаємодії з групами вітчизняних та міжнародних зацікавлених сторін, що стане в подальшому основою для розвитку корпоративної соціальної відповідальності.

Під час визначення механізмів взаємодії зі стейколдерами слід зважити на той факт, що наразі виділяють нову стадію розвитку корпоративної соціальної відповідальності "Стадію стратегічного партнерства зі стейкхолдерами", яка є найбільш ефективною і дієвою в сучасних умовах господарювання ПАТ "Українська залізниця". Суть стадії полягає в тому, що корпорація просуває базові положення корпоративної соціальної відповідальності серед своїх стратегічних партнерів 3 метою отримання максимальних соціально-економічних вигід та забезпечення тривалої результативної взаєMOAiï.

Зважаючи на загострення конкуренції на ринку транспортно-логістичних послуг як на вітчизняному, так і на міжнародному ринку, та необхідності пошуку нових шляхів забезпечення ефективності діяльності ПАТ "Українська залізниця", підвищення інвестиційної привабливості галузі та нарощення його техніко-техно- 
логічного потенціалу вважаємо за доцільне в якості пріоритету розвитку виділити взаємодію української залізничної компанії з групами міжнародних стейкхолдерів:

1. Міжнародні суб'єкти освіти та освітні програми (Royal Holloway, TEMPUS, University of London, Міжнародний університет логістики і транспорту Мадридський політехнічний університет, Erasmus+ та ін.).

Така взаємодія повинна грунтуватись на необхідності розширення підготовки та перепідготовки кадрів залізничного транспорту за межі своєї національної освітньої системи, що в свою чергу грунтується на інтенсивному розвитку міжнародних професійно-педагогічних і науково-освітніх зв'язків, здійсненні діяльності галузевих закладах освіти відповідно до єдиних міжнародних норм, результатом чого повинно стати забезпечення високої якості освіти працівників залізничного транспорту.

ПАТ "Українська залізниця" повинна розглядати використання можливостей інтернаціоналізації освіти як спосіб посилення позицій вітчизняного залізничного транспорту за рахунок зростання продуктивності праці, підвищення його конкурентоспроможності. Використання переваг міжнародної освіти - це свого роду елемент "м'якої сили" в конкурентній боротьбі на світовій арені, а також найважливіший інструмент забезпечення ефективної співпраці ПАТ "Українська залізниця" з іноземними стратегічними партнерами.

Ефективна взаємодія в цій сфері забезпечує збільшення інвестицій, інноваційних технологій і прогресивних задумів. Найважливішим пріоритетом стає створення умов для підготовки українських та залучення зарубіжних висококваліфікованих фахівців в інтересах інноваційного розвитку українського залізничного транспорту та економіки в цілому.

В умовах глобалізації, зовнішньополітичного та економічного контексту вітчизняні залізниці вже не можуть абстрагуватися від інтернаціоналізації як світової тенденції розвитку. Експерти усвідомлюють, що лідируючі місця на світовому транспортно-логістичному ринку будуть займати ті компанії, які швидко відреагують на зміни, що відбуваються в суспільстві і в сфері забезпечення високого рівня професійної підготовки кадрів.

2. Міжнародні суб'єкти екологічної діяльності (Глобальний екологічний фонд, Екологічний союз, Інститут розвитку територіальних общин, Европейське агентство навколишнього середовища та ін.)

Також одним із не менш необхідних для українських залізниць є реалізація екологічного аспекту корпоративної соціальної відповідальності.

Наразі на підприємствах залізничного транспорту найпоширенішими є практики впровадження енергозберігаючих технологій (Аля 86 \% виробничих підрозділів ПАТ "Українська залізниця") та програми сортування й утилізації відходів (для $46 \%$ виробничих підрозділів ПАТ "Українська залізниця"). Інші сучасні передові напрями реалізації екологічної складової корпоративної соціальної відповідальності майже на застосовуються в практиці господарювання вітчизняного залізничного транспорту.

Зважаючи на розмір негативного впливу залізничного транспорту на екологію та можливі негативні наслідки екологічних катастроф пов'язаних із функціонуванням ПАТ "Українська залізниця" своєчасним є використання переваг стратегічного партнерства 3 міжнародними суб'єктами екологічної діяльності.

Крім того, посилення геополітичного впливу на процеси міжнародної економічної стратегічної співпраці залізничного транспорту також актуалізують значущість розвитку ефективного міжнародного співробітництва з питань екології.

Саме стурбованість глобальними екологічними проблемами спонукає керівництво залізничного транспорту до вдосконалення механізмів економічного зростан- ня ПАТ "Українська залізниця" на засадах раціонального природокористування.

Розробка та використання удосконаленого формату ділового співробітництва збільшить функції корпоративного управління в контексті необхідності протидії екологічним кризам внутрішнього та зовнішнього середовища залізничного транспорту, що мають міжнародний характер прояву. Основна діяльність 3 огляду у спектрі тактичних і стратегічних завдань у напрямку зовнішньоекономічної політики застосовує комплекс заходів, методів і практичних дій для досягнення бізнескомпромісів і взаємоприйнятних рішень 3 метою покращення економічних відносин між країнами та формування міжнародної екологічної безпеки.

Успіх здобуття конкурентних переваг на світовому ринку передбачає використання інваріантних моделей бізнесу, які спроможні посилювати еколого-економічні інтереси агентів ринку і послаблювати економіко-політичні конфронтації та соціально-екологічні дисонанси. Саме тому екологічний вектор комерційної дипломатії спроможний впливати на процеси вироблення й узгодження національних інтересів країн щодо їх захисту і лобіювання на міжнародному рівні, ратифікації міжнародних угод та їх інкорпорації в систему національного законодавства; при здійсненні переговорного процесу 3 урегулювання різних конфліктів; під час підготовки аналітичних матеріалів 3 питань еколого-економічної політики іноземних держав; при участі в підготовці рекомендацій і матеріалів для національних представників на сесіях міжнародних організацій, міжнародних конференціях, ділових міжнародних форумах, переговорах і консультаціях щодо екологізаціі зовнішньоекономічної діяльності країн.

3. Міжнародні суб'єкти інвестиційної діяльності залізничного транспорту (Европейський банк, Азіатський банк інфраструктурних інвестицій, Новий банк розвитку БРІКС та ін.)

Сьогодні міжнародні суб'єкти інвестиційної діяльності $є$ активною групою стейкхолдерів, що вже зараз повноцінно і неодноразово співпрацюють 3 багатьма залізничними компаніями інших країн світу (Казахстан, Білорусь, Туркменістан та ін.), а тому визначення стратегічних напрямків співпраці з ними є для ПАТ "Українська залізниця" вельми актуальним питанням. Наразі вітчизняний залізничний транспорт майже не використовує потенціал міжна родного фінансового співробітництва для інвестування власних проектів інфраструктурного розвитку.

4. Міжнародні організації інфраструктурної діяльності залізничного транспорту (Організація співробітництва залізниць, Міжнародна організація залізничних перевезень, Міжнародний комітет та ін.)

За умов високої конкуренції на світових транспортних ринках сфера міжнародних стратегічних взаємовідносин вимагає від її суб'єктів удосконалення компетенцій з метою захисту національних інтересів; укладання взаємовигідних інфраструктурних угод; підтримки вітчизняного залізничного транспорту в секторах міжнародної діяльності; вжиття превентивних заходів щодо попередження появи кризових явищ на транспорті (економічних, інфраструктурних, екологічних та ін.); налагодження дієвого бізнес-діалогу; мирного врегулювання професійно-ділових суперечок тощо.

Глобалізація та економізація зовнішньої політики розширюють спектр цілей міжнародних стратегічних взаємовідносин, використовуючи для цього нові методи їі застосування. Про це свідчить ринкова домінантність корпоративної безпеки, складові якої орієнтовані на захист: "ідей" бізнесу та обраної бізнес-моделі поведінки компанії на ринку; "процесу" реалізації ефективної інфраструктурної, соціальної, інноваційної, цінової та екологічної політики; "систем управління кризами" в основній діяльності залізничного транспорту. Виникають різноманітні аспекти стратегічної взає- 


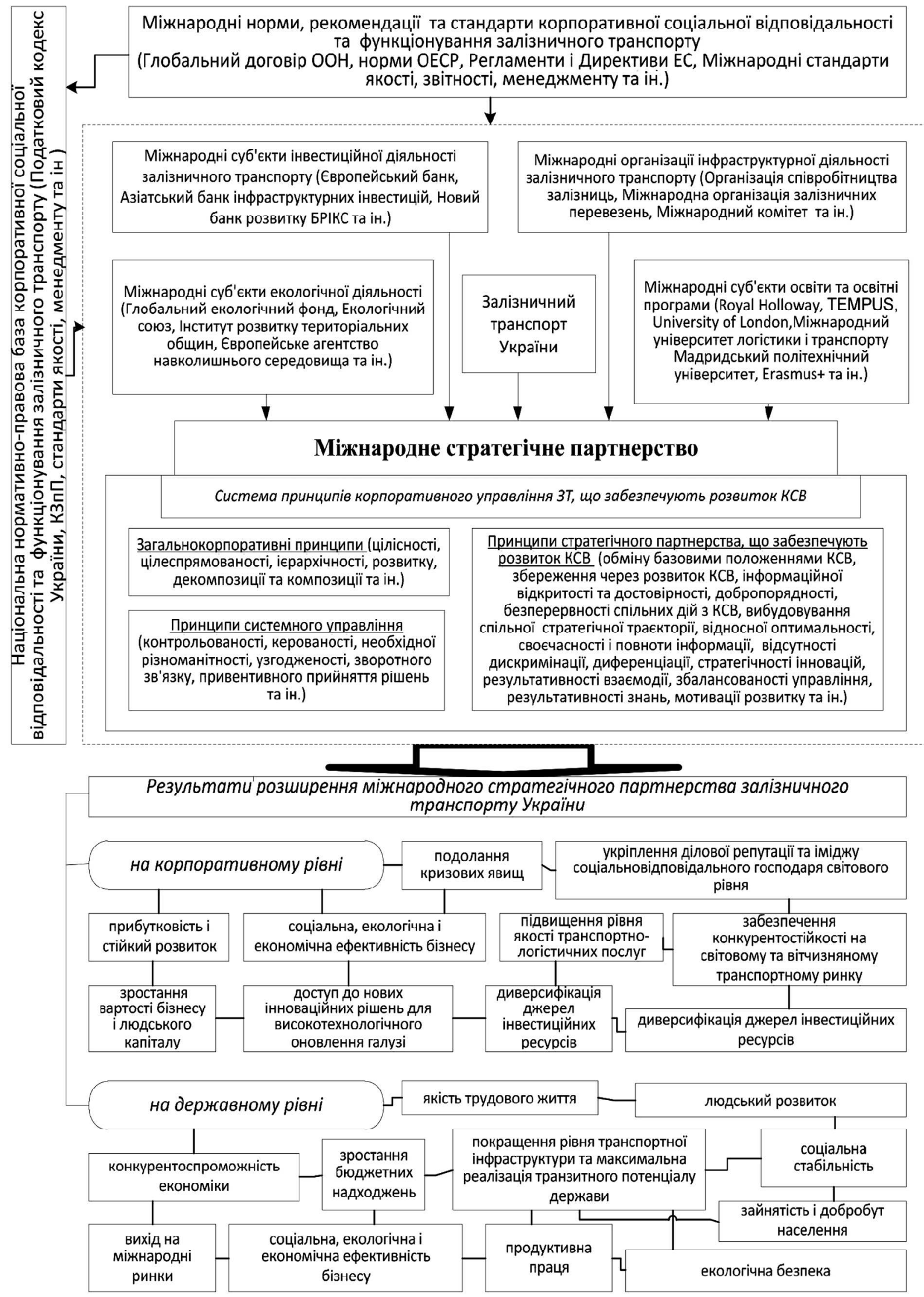

Рис. 1. Організаційно-економічний механізм формування стратегічного партнерства за участю залізничного транспорту та міжнародних стейкхолдерів

модії суб'єктів міжнародної бізнес-співпраці, що характеризуються такими тенденціями, як генерування бізнес-інновацій; модифікація інформаційних потоків; створення міжнародних бізнес-концептів екологічного спрямування; збільшення кількості інноваційно-фінан- сових структур; утворення новітніх ринків праці та напрямків реалізації корпоративної соціальної відповідальності.

З огляду на це забезпечення кращих умов для міжнародного стратегічного партнерства не тільки спонукає 
міжнародних партнерів до прийняття компромісних рішень на основі обоюдних поступок, але й має на меті використання зовнішніх джерел розвитку та формування переваг. Такі механізми стратегічного партнерства покращують функціонування залізничного транспорту, збільшують його потенціал у міжнародній інтеграції, а також забезпечують розвиток корпоративної соціальної відповідальності.

Саме тому стратегічна взаємодія повинна здійснюватись на основі система принципів корпоративного управління 3Т, що забезпечують розвиток корпоративної соціальної відповідальності (рис. 1). Зазначена система повинна гармонійно поєднувати в собі:

1) загальнокорпоративні принципи (цілісності, цілеспрямованості, ієрархічності, розвитку, декомпозиції та композиції та ін.);

2) принципи системного управління (контрольованості, керованості, необхідної різноманітності, узгодженості, зворотного зв'язку, привентивного прийняття рішень та ін.);

3) принципи стратегічного партнерства, що забезпечують розвиток корпоративної соціально ї відповідальності (обміну базовими положеннями корпоративної соціальної відповідальності, збереження через розвиток корпоративної соціальної відповідальності, інформаційної відкритості та достовірності, добропорядності, безперервності спільних дій 3 корпоративної соціальної відповідальності, вибудовування спільної стратегічної траєкторії, відносної оптимальності, своєчасності і повноти інформації, відсутності дискримінації, диференціації, стратегічності інновацій, результативності взаємодії, збалансованості управління, результативності знань, мотивації розвитку та ін.).

Аля максимального забезпечення виконання принципів інформаційної відкритості та достовірності під час стратегічної взаємодії інформаційна політика ПАТ "Українська залізниця" повинна бути направлена на найбільш повне і своєчасне задоволення потреб всіх виділених міжнародних груп зацікавлених сторін в достовірній інформації про діяльність компанії і події, що відбуваються навколо неї. Інформаційна політика також повинна базуватися на вітчизняній та міжнародній практиці корпоративного управління і консолідувати вимоги вітчизняних та міжнародних стандартів корпоративного управління з питання розкриття інформації. ПАТ "Українська залізниця" не має ухилятися від розкриття негативної інформації про себе, якщо ця інформація, яка $є$ конфіденційною, здатна вплинути на прийняття інвестиційних або інших рішень зацікавленими сторонами.

\section{ВИСНОВКИ}

У результаті аналізу особливостей господарювання залізничного транспорту, взаємодії його зі стейкхолдерами та виконання положень корпоративної соціальної відповідальності запропоновано організаційно-економічний механізм формування міжнародного стратегічного партнерства за участю залізничного транспорту, що на відміну від інших доповнено системою принципів та ключовими групами міжнародних стейкхолдерів. Це дозволить забезпечити розвиток корпоративної соціальної відповідальності залізничного транспорту, сприятиме подоланню кризових явищ у галузі та створить підгрунтя для формування конкурентних переваг вітчизняним залізницям у довгостроковій перспективі.

Мітература:

1. Колот A.M. Соціальна відповідальність: теорія і практика розвитку: монографія / А.М. Колот, О.А. Грішнова. - К.: KНЕУ, 2012. - 501 с.

2. Саприкіна М.А. Корпоративна соціальна відповідальність: моделі та управлінська практика: посібник /
М.А. Саприкіна, М.А. Саєнсус, А.Г. Зінченко. - К.: Фабований лист, 2011. - 470 с.

3. Котлер Ф. Корпоративна соціальна відповідальність / Ф. Котлер, Н. $\Lambda$ i // Як зробити якомога більше добра для вашої компанії та суспільства / Пер. 3 анг. С. Яринич. - К.: Стандарт, 2005. - С. 4.

4. Аикань В.А. Перспективы развития экономики Украины в условиях формирования международных транспортных коридоров в системе мировой глобализации экономики / В.А. Аикань // Вісник економіки транспорту і промисловості. - 2013. - Вип. 42. C. $144-149$.

5. Токмакова I.B. Концепція забезпечення гармонійного розвитку залізничного транспорту України / I.В. Токмакова // Агросвіт. - 2015. - № 11. - С. 38 43.

6. Овчиннікова В.О. Особливості державного регулювання розвитку залізничного транспорту України [Електронний ресурс]/В.О. Овчиннікова// Економіка та суспільство. - 2017. - № 12. - Режим доступу: http:// economyandsociety.in.ua

7. Проект Концепції соціального розвитку України на 2013-2023 рр. [Електронний ресурс]. - Режим доступу: http://mlsp.gov.ua/control/uk/publish/article?art_id $=153212-\&$ cat_id $=107177$

8. Про затвердження Стратегічного плану розвитку залізничного транспорту України на період до 2020 року [Електронний ресурс]: наказ Міністерства інфраструктури 21.12.2015 p. № 547. - Режим доступу: https:/ /mtu.gov.ua/documents/443.html

9. Офіційний сайт "ПАТ "Українська залізниця" [Електронний ресурс]. - Режим доступу: http:// www.uz.gov.ua/about/investors/credit_ratings/

References:

1. Kolot, A. M. and Grishnow, O. A. (2012), Sotsial'na vidpovidal'nist': teoriia i praktyka rozvytku [Social responsibility: theory and practice of development], KNEU, Kyiv, Ukraine.

2. Saprikina, M. A. Saensus, M.A. and A.G. Zinchenko, (2011), Korporatyvna sotsial'na vidpovidal'nist': modeli ta upravlins'ka praktyka [Corporate Social Responsibility: models and management practice], Fabovanyj lyst, Kyiv, Ukraine.

3. Kotler, F. and Lee, N. (2005), "Corporate Social Responsibility", Yak zrobyty iakomoha bil'she dobra dlia vashoi kompanii ta suspil'stva [How to make the best possible for your company and society], Standard, Kyiv, Ukraine.

4. Dikan, V. L. (2013), "Prospects of the development of the economy of Ukraine in the conditions of formation of international transport corridors in the system of world globalization of economy", Bulletin of the Economy of Transport and Industry, vol. 42, pp. 144-149.

5. Tokmakova, I. V. (2015), "Conception of harmonious development of railway transport of Ukraine", Agrosvit, vol. 11 , pp. $38-43$.

6. Ovchynnikova, V. O. (2017), "Features of state regulation of railway transport development in Ukraine", Economics and Society, vol. 12, pp. 53-56.

7. Ministry of Social Policy of Ukraine (2013), "Draft Concept of Social Development of Ukraine on 2013 2023", available at: http://mlsp.gov.ua/control/uk/publish/ article?art_id=153212-\&cat_id=107177 (Accessed 30 Oct 2018).

8. Ministry of Infrastructure of Ukraine (2015), "On Approval of the Strategic Plan for the Development of Rail Transport of Ukraine for the period up to 2020", available at: https://mtu.gov.ua/documents/443.html (Accessed 30 Oct 2018).

9. Official site of PJSC "Ukrainian Railway" (2018), available at: http://www.uz.gov.ua/about/investors/ credit_ratings/ (Accessed 30 Oct 2018).

Стаття надійила до редакиії 12.11.2018 р. 
Я.В. Колеснік, к.е.н., дочент кафедри фінансів, банківсъкої справи та страхування, Аніпровсъкий державний аграрно-економічний університет A. О. Криворучко, магістр, Аніпровсъкий державний аграрно-економічний університет

\title{
ПЕРСПЕКТИВИ РОЗВИТКУ ФІНАНСОВОГО МЕНЕАЖМЕНТУ У СФЕРІ СПОЖИВЧОГО ТА ІПОТЕЧНОГО КРЕАИТУВАННЯ
}

\author{
Ya. Kolesnik, \\ PhD in economics, associate Professor of finance, banking and insurance \\ Dnipro State Agrarian and Economic University \\ A. Krivoruchko, \\ master's degree, Dnipro State Agrarian and Economic University
}

\begin{abstract}
PERSPECTIVES FOR DEVELOPMENT OF FINANCIAL MANAGEMENT IN CONSUMER AND MORTGAGE LENDING
\end{abstract}

У статті розгАянуто проблеми розвитку Споживчого та іпотечного кредитування, його роль у банківській системі України. Проведено аналіз теоретичних аспектів споживчого кредитування, наведено приклади успішного функціонування стабільних банківських установ задіяних у сфері споживчого кредитування, переглянуто важливість внутрішніх і національних Стандартів діяльності фінансових інституцій, розкрита суть і причини підвищення рівня простроченої та проблемної заборгованості за цим видом кредиту та приділено увагу питанню захисту прав Споживачів фінансових послуг в Украӥні з боку держави. Запропоновано шляхи покращення ситуації, що скАалася на ринкукредитних послуг, та оцінено перспективи та стратегї̈ розвиткуцього видукредитування у майбутньому.

The article deals with the problems of development of consumerand mortgage lending, its role in the banking system of Ukraine. The analysis of the theoretical aspects of consumer lending is carried out, examples of successful functioning of stable banking institutions involved in consumer lending are presented, the importance of internal and national standards of financial institutions activity has been reviewed, the essence and reasons for raising the level of overdue and problem debts under this type of credit have been reviewed, and attention has been paid to the issue of protection of the rights of consumers of financial services in Ukraine by the state. The ways of improvement of the situation on the market of credit services are offered, and the prospects and strategies of development of this type of lending in the future are estimated.

The banking system of Ukraine today is considered one of the most advanced elements of the economic mechanism, since its reform was started earlier than other sectors of the economy, which was determined by the key role of banks in solving the problems of the transition to a market economy. At this stage one of the most developed and most widespread banking products is bank consumer credit. Current performance indicators in the banking sector of the country are significantly better than those observed in past years. Today, the growth of business activity of the population is observed, the issue and infrastructure of credit cards continues to grow, new products are introduced, various forms of deposits, Internet banking, and so on. A wide range of credit, guarantee, settlement, documentary and depository operations is being implemented, interbank competition for types and volumes of provision to the private sector of services, banking products, and their quality is increasing. 
However, despite all the positive developments, the banking sector of Ukraine remains unsatisfactory today. According to the general results of the activity, it is unprofitable and contains numerous problems caused both by the crisis phenomena of the economy, and by the monetary policy of the National Bank of Ukraine, by actions of the authorities and by internal banking factors.

Ключові слова: кредит, споживчий кредит, кредитна політика, відсоткова ставка, платоспроможність, захист прав споживачів, фінансові послуги, іпотечне кредитування.

Key words: credit, consumercredit, credit policy, interest rate, solvency, consumer protection, financial services, mortgage lending.

\section{ПОСТАНОВКА ПРОБЛЕМИ}

Останнім часом банки різних країн усе гостріше відчувають проблеми, пов'язані з наданням послуг у сфері банківського кредитуванням. Ця ситуація найбільш актуальна для вітчизняної банківської системи, де рівень простроченої позичкової заборгованості протягом останніх $5-7$ років мав стійку тенденцію до зростання. Велика кількість банків зазнають втрат від недосконалої оцінки кредитного ризику, що спонукає їх до завищування відсоткової ставки за кредитами, від чого, у свою чергу, потерпають позичальники. Українська банківська система побудована відповідно до принципу дворівневості, який передбачає чітке розмежування сфер діяльності центрального (Національного банку України) і комерційних банків.

Банківська система України сьогодні вважається одним із найрозвинутіших елементів господарського механізму, оскільки їі реформування було розпочато раніше за інші сектори економіки, що визначалося ключовою роллю банків при вирішенні завдань переходу до ринкової економіки. На цьому етапі одним з найрозвинутіших і найпоширеніших банківських продуктів $€$ банківський споживчий кредит. Нинішні показники діяльності у банківському секторі країни значно кращі за ті, які спостерігалися у минулі роки. Сьогодні спостерігається зростання ділової активності населення, продовжує розвиватись випуск та інфраструктура кредитних карток, впроваджуються нові продукти, різноманітні форми депозитів, інтернет-банкінг та інше. Здійснюється широкий спектр кредитних, гарантійних, розрахункових, документарних і депозитарних операцій, посилюється міжбанківська конкуренція за види та обсяги надання приватному сектору послуг, банківських продуктів, підвищується їхня якість. Проте, незважаючи на усі позитивні зрушення, банківський сектор України залишається на сьогодні не досить досконалим. За загальними результатами діяльності він $€$ збитковим і містить численні проблеми, викликані як кризовими явищами економіки, так і грошово-кредитною політикою Національного банку України, діями влади і внутрішньобанківськими факторами.

\section{АНАЛІЗ ОСТАННІХ ДОСЛІДЖЕНЬ І УУБЛІКАЦІЙ}

Значне зростання споживчого кредиту в Україні стало важливим чинником розвитку банківської системи й економіки в цілому. Проте надто прискорене і недостатньо контрольоване зростання споживчого кредиту загострило проблеми незбалансованості товарних і кредитного ринків і сприяло нагромадженню ризиків. Сучасний банківський бізнес супроводжують високий рівень конкуренції, ускладнення архітектури фінансового ринку та його дерегулювання, зміни в організації кредитування. Водночас суб'єкти споживчого кредиту в Україні виявились не готовими до суттєвих трансформацій, а надмірна активізація банків щодо кредитування населення посилила загрози стійкості окремих банків і всієї банківської системи. Тому актуальними $є$ дослідження шляхів ефективного розвитку споживчого кредиту в перспективі та вдосконалення підходів до його регулювання. Проблемам розвитку споживчого кредиту в науковій літературі приділяється належна увага. Фундаментальні основи досліджені такими вченими: А. Смітом, А. Маршалом, Э.Аж. Аоланом, В. Аексісом, Т. Туком, Е. Рідом, Р. Коттером, М. Туган-Барановським, Аж. Сінком. Вагомий внесок у дослідження спо- живчого кредиту зробили провідні вітчизняні науковці: М. Алексеєнко, О. Евтух, 4 Б. Івасів, В. Аагутін, А. Мороз, М. Савлук, Р. Тиркало та науковці зарубіжних країн: А. Казимагомедов, О. Ааврушин, Є. Жуков, Г. Панова та інші.

\section{META CTATTI}

Мета дослідження полягає в аналізі теоретичних аспектів споживчого кредитування, розгляді організації споживчого кредитування в банках України та політики банківских установ щодо цього питання. Визначення основних проблем та слабких місць в сфері споживчого та іпотечного кредитування, та стратегії розвитку данного виду позики в майбутньому.

\section{ВИКЛАД ОСНОВНОГО МАТЕРІАЛУ ДОСЛІДЖЕННЯ}

Споживчий кредит - це кошти, що надаються кредитодавцем (банком або іншою фінансовою установою) фізичним особам на придбання споживчих товарів або послуг у тимчасове користування, під процент, на умовах строковості та платності. Цільове призначення даного виду кредитування спрямоване на придбання товарів тривалого користування, а саме автомобілів, меблів, складної побутова техніки, на споживчі цілі, на навчання, лікування тощо. Споживчий кредит можуть надавати як банківські установи, кредитні спілки, ломбарди, а також суб'єкти господарювання,що обслуговують сфери торгівлі чи надання послуг. На сьогоднішній день поширення набув різновид споживчого кредиту під заробітну плату без визначення цільового використання одержаних кредитних коштів. Иого перевагами $є$ короткі терміни оформлення та відсутність поручителів або застави. Такі кредити можуть надаватися на основі існуючої кредитної картки, портфеля українських банків другий рік поспіль, на що помітно вплинув статистичний ефект - неплатоспроможні банки, у яких відкликано ліцензію, не надають даних про їх кредитну заборгованість. У свою чергу платоспроможні банки на початку 2018 року показали помірне зниження розміщення кредитних ресурсів між суб'єктами господарювання та фізичними особами. На сьогоднішній день спостерігається наступна ситуація, банківське кредитування майже повністю зосереджено в сегменті суб'єктів господарювання юридичних осіб. Його питома вага в загальному кредитному портфелі банків зросла з $64 \%$ у вересні 2008 року до $83 \%$ у березні 2018 року. Серед кредитів, що обслуговуються (I-III категорії якості за класифікацією Національного банку), частка суб'єктів господарювання на кінець I кв. 2018 року становила 89\%.

Залежно від розміру банку, його структури та профілю діяльності підходи до розуміння сутності споживчих кредитів та управління ризиками, які притаманні цьому виду кредитів різняться. Розуміння сутності споживчих кредитів, використання та побудова системи управління ризиками, що притаманні цьому кредиту, методи та інструменти, які при цьому використовуються, всі ці аспекти формують різнопланові моделі ведення бізнесу з надання споживчих кредитів.

Але поряд $з$ позитивними тенденціями, з огляду на широкий спектр послуг та видів у сфері кредитування, спостерігається скорочення кредитного ринку. У процесі управління ризиками кредитування в банку важливе місце має класифікація кредитів, тобто виокремлення споріднених кре- 
дитів за їх природою та інструментарієм управління ризиками, що їм притаманні. Виходячи з цього, банки виділяють кредити юридичним та фізичним особам, сстанні, в свою чергу, поділяються на забезпечені та незабезпечені. Ао забезпечених можна відностиіпотечні кредити та автокредити.Ао незабезпечених — кредити на купівлю побутової техніки, кредитні картки та інші кредити готівкою. Відповідно іпотечні автокредити та кредити на купівлю побутової техніки належать до цільових кредитів, всі інші - нецільових.

Відповідно до статті 1 закону України "Про іпотеку" "іпотека - це вид забезпечення виконання зобов'язання нерухомим майном, що залишається у володінні і користуванні іпотекодавця, згідно з яким іпотекодержатель має право у разі невиконання боржником забезпеченого іпотекою зобов'язання одержати задоволення своїх вимог за рахунок предмета іпотеки переважно передіншими кредиторами цього боржника" [1]. Аля забезпечення фінансової стабільності держави і попередження кризових явищ саме розвиток іпотечного кредитування житла вимагає формування дієвої інфраструктури іпотечного ринку, посилення контролю держави за забезпеченням системного балансу між сукупною ціною цінних паперів і закладних, які іпотечні банки надають емітентам для забезпечення їхніх емісій. На сучасному етапі, внаслідок нестабільної політичної та економічної ситуації в країні причиною загального падіння рівня економіки є гальмування розвитку іпотечного кредитування. Більш жорстокі вимоги кредитування, постійно зростаючі ставки за кредитами, збільшення порогу для початкового внеску, підвищенні штрафи по заборгованості на рівні з низькими доходами населення роблять іпотеку для них недосяжною мрією, конкуруючою з зростаючим попитом на житло. Згідно з визначенням Національного банку України іпотечний житловий кредит (residential mortgage loan) - довгостроковий кредит, що надається фізичній особі, товариству співвласників квартир або житловому кооперативу Аля фінансування витрат, пов'язаних з будівництвом або придбанням квартири чи житлового будинку (з урахуванням землі, що знаходиться під таким житловим будинком, чи присадибної ділянки), які надаються у власність позичальника 3 прийняттям кредитором такого житла (землі, що знаходиться під ним, чи присадибної ділянки) під заставу. Іпотечне кредитування в ВВП країн-членів $Е С$ становлять близько $35 \%$, України - 6,1\%. Безпосередньо, умови отримання іпотечного кредиту в країнах Європейського Союзу суттєво відрізняються від українських. Все також залежить від умов кредитування, наприклад, чим менше ставка, тим більше сума або термін надання кредиту та навпаки. У середньому банки України надають іпотечні кредити близько 1 млн грн на 12-24 місяці, за ставками 20$28 \%$ річних. Головними банками по наданню кредитів на нерухомість за народним рейтингом згідно даних українського фінансового форуму є: Глобус (Київ), Піреус Банк (Київ), Аркада (Київ), Банк інвестицій та заощаджень (Київ) , Кредобанк (Цьвів), Ощадбанк (Київ), саме вони потрапляють в перелік платоспроможних банків згідно діагностики НБУ [5].

Здійснення захисту прав споживачів фінансових послуг в Україні з боку держави сьогодні регламентується такими законодавчими актами, як Цивільний кодекс України; Закони "Про захист прав споживачів", "Про споживче кредитування", "Про банки і банківську діяльність" "Про організацію формування та обігу кредитних історій", "Про рекламу", "Про захист від недобросовісної конкуренції" та інші. Захисту прав споживачів фінансових послуг присвячені і нормативні акти НБУ: Постанова "Про заходи щодо забезпечення погашення кредитів" № 461 від 06.08.2009 р., яка містить рекомендації банкам, спрямовані на зниження ризиків банківської діяльності та недопущення втрати довіри до банківської системи; "Правила надання банками України інформації споживачу про умови кредитування та сукупну вартість кредиту", затверджені постановою Правління НБУ № 168 від 10.05.2007 р.Аетально інформацію для громадян, які вирішили отримати кредит, викладено в "Пам'ятці позичальника банку за споживчим кредитом", що розміщена на інтернет-сторінці НБУ, а також у "Пам'ятці позичальнику, що має заборгованість перед банком за споживчим кредитом і потрапив у скрутне становище", яка спрямована на захист прав кредиторів і має превентивний характер для зниження ризиків кредитування [5].

Сьогодні дуже мало уваги приділяється внутрішнім і національним стандартам діяльності фінансових інституцій, у тому числі і банків, хоча саме вони являються уніфікованими мінімальними вимогами, що використовують регулятори і саморегулюючі організації (національні стандарти) та фінансові інститути (внутрішні стандарти). Значення національних стандартів зводиться до об'єднання й уніфікації внутрішніх стандартів окремих інституцій (банків), а також до гармонізації діяльності національних інститутів із зовнішнім середовищем. Національні стандарти аналізуються міжнародними організаціями, визначаються кращі 3 них, що в свою чергу, далі враховуються у розробленні міжнародних стандартів і розповсюджуються як найкраща практика [4].

Серед вагомих причин необхідності розвитку національних стандартів якості банківської діяльності, в тому числі в сфери кредитування є зміна зовнішнього середовища функціонування банків, зміна нормативної бази регулювання, різні форми конкуренції з іноземними банками. Але серед найважливіших виділяється саме встановлення довіри між різними суб'єктами економічних зв'язків банків: між банками, між банками та їх клієнтами, між банками та регулятором. Наявність стандартів значно оптимізує комунікаційні та бізнес-процеси банків. Основна логіка використання стандартів у забезпеченні ефективного функціонування ринку надання кредитних послуг та ринку банківських споживчих кредитів, зокрема, полягає в тому, що певний стандарт (група стандартів) 一 це вже чіткий, означений параметр контролю, $є$ контроль - $є$ основа регулювання, $€$ регулювання - $€$ вплив на сегмент загалом і на окремих його учасників. Стандарти кредитування у широкому розумінні аналогічні принципам кредитування; у вузькому - це формальні й неформальні правила, яким має відповідати загальновизнана найкраща практика організації та здійснення кредитного процесу.

Використання стандартів повинно бути притаманне всьому процесу кредитування, тому їх можна диференціювати відповідно до його етапів. Виходячи 3 цього, серед стандартів кредитування доцільно виділяти стандарти інформаційного обслуговування; оцінки кредитоспроможності; оцінки кредитного ризику, що пов'язаний із наданням кредиту; оцінки якості забезпечення кредиту; кредитного договору; процедури видачі кредиту; кредитного моніторингу, в тому числі щодо проблемної заборгованості.

Видача споживчих кредитів такому широкому колу осіб з високою ймовірністю вплине на підвищення рівня простроченої та проблемної заборгованості за цим видом кредиту. Аля роботи із заборгованістю банки використовують послуги колекторських агентств або залучають власний відділ роботи з проблемною заборгованістю. Безнадійна заборгованість підлягає списанню.

Останнім етапом $є$ корегування умов видачі кредиту, а саме: зміна кредитних правил, вікові обмеження, обмеження видачі пенсіонерам, окремим соціальним групам, обмеження щодо суми заробітної плати, · зміни кредитного продукту, ставка, термін, мінімальна/максимальна сума, цільова група. Проте зміна умов може відбуватися не лише для нових продуктів, але й через тривалість періоду, зміни в бізнесі, фази економічного циклу та через інші зовнішні фактори. Якість прийнятих рішень у кредитуванні - це основний фундамент, на якому будується успішний кредитний бізнес. Швидкість 3 якою ухвалюються рішення, а також надійність і прозорість бізнес-процесів стають вирішальними факторами сьогодення. Час видачі кредиту має надважливе значення, тому що є однією із конкурентних переваг, 
адже за невеликих сум видача кредитів має займати не набагато більше часу, ніж купівля товару.

На сьогодні в Україні з боку кредиторів проблема полягає у зниженні здатності позичальників своєчасно погашати кредити, у збільшенні ризику неповернення кредитних коштів, відтак, у зростанні ризику зниження ліквідності кредитних установ, а зі сторони позичальників, проблемами є високі процентні ставки за кредитами. Не менш важливою $є$ проблема низького рівня інформаційної обізнаності населення щодо умов кредитування та низький рівень кваліфікації персоналу банківських установ, які, на жаль, неспроможні надати якісні консультаційні послуги клієнтам.

Після подолання економічної кризи у банківському секторі України, існують значні перспективи розвитку короткострокового кредитування населення для придбання товарів народного споживання. Пояснюється це тим, що за такого виду кредитування ризиковість операцій значно менша, оскільки терміни кредитування невеликі (до одного року), а суми порівняно незначні. Збільшення обсягів довгострокового кредитування населення $€$ ще одним напрямом у концепції становлення споживчого кредитування на вітчизняному ринку банківських послуг. Важливою $є$ інтенсифікація розвитку житлового кредитування фізичних осіб. Цей сегмент ринку сьогодні розвивається недостатніми темпами, хоч йому прогнозують значні перспективи [3]. Також важливу роль в Україні відіграє розвиток іпотечного кредитування. Іпотечний кредит - це особлива форма кредиту, пов'язана 3 наданням позик під заставу нерухомого майна - землі, виробничих або житлових будівель тощо. Іпотечні позики надаються на довгостроковій основі. Іпотечний кредит стає можливим лише за умови приватної власності на землю і нерухомість. Він дозволяє землевласникам фінансувати отримання додаткових ділянок землі, а підприємцям збільшити розміри виробництва.

Іпотека виконує такі функції:

$-\epsilon$ інструментом залучення фінансових коштів в економіку;

- забезпечує повернення позичених коштів.

- стимулює обіг нерухомості, коли інші способи (купівля, продаж тощо) економічно недоцільні або юриАично неможливі.

Перевагами такої форми залучення фінансових ресурсів $€$ те, що процес іпотечного кредитування дозволить вирішити цілий ряд соціально-економічних проблем суспільства. Воно забезпечить розвиток довгострокового житлового будівництва, вирішить проблему кредитування підприємств агропромислового комплексу. Також розвиток іпотечного кредитування сприяє реформуванню економіки держави загалом.

\section{ВИСНОВКИ}

На сьогоднішній день регулювання ринку є досить ліберальним. $\Lambda$ ише незначна кількість банківських установ надає іпотечні кредити. Більшість таких кредитів надаються обсягом до 2 млн грн, а кредитний ризик враховує лише факт прострочки. Це пояснюється тим, що банківські установи до сих пір активно не працюють 3 кредитуванням нерухомості. Така позиція пояснюється браком достатньої інформації про доходи та кредитну історію фізичних осіб.

Світовою практикою встановлено, що осередком економічного і соціального розвитку країни виступає налагоджені взаємозв'язки з ринками перерозподілу фінансових ресурсів, і в тому числі забезпечених заставою нерухомості. Іпотечне кредитування в Україні виступає головним елементом у фінансово-кредитному механізмі забезпечення населення доступним житлом, однак користується не досить великим попитом, що зумовлено раціональним підходом більшості споживачів кредитування, яких не задовольняють умови банківських іпотечних програм та/або відсутність можливості своєчасного погашення платежів і забезпечення достатнього рівня жит- тя родини в цей період, що підкріплюється негативними процесами в політичній та економічній сферах.

Проведене дослідження дозволяє зробити такі висновки:

1. Існують потенційні можливості для розвитку іпотечного кредитування, що зумовлено попитом на житло і відповідно інвестиційною привабливістю ринку нерухомості, 3 одночасною зацікавленістю держави, фізичних та юридичних осіб, за умови адекватності умов програм реаліям та захищеності сторін в умовах зниження інвестиційного ризику.

2. Обов'язкова подальша підтримка держави на покращення фінансування іпотечних програм для різної категорії населення з коригуванням цільових груп надання пільгових кредитів та компенсації відсоткових ставок та стимулювання будівництва доступної житлової нерухомості.

3. Новим кроком у розвитку іпотечного кредитування має стати державно-приватне партнерство в забезпеченні населення власним та орендним житлом 3 використанням кредитних коштів.

4. Поєдання кредитного та накопичувального механізмів забезпечить розвиток кредитування через створення впевненості у змозі виплачувати кредит зі сторони населеняя, чому сприятиме наявність пільгових депозитних програм для накопичення коштів для придбання доступного житла 3 контролем за їх використанням.

Щодо питання розвитоку споживчого кредитування України, то воно залежить від подолання кризових явищ як у країні, так зокрема у банківському секторі це стабільності валютного курсу, зниження інфляційних процесів, покращенні якості активів банківської системи, збільшенні ресурсної бази, покращення інвестиційного клімату та відновленні довіри населення.

\section{\ітература:}

1. Закон України "Про іпотеку" від 05.06.2003 року № 898-IV [Електронний ресурс]. - Режим доступу: http://zakon.rada.gov.ua/laws/show/898-15

2. Васюренко О.В. Банківські операції: навч. посібн. - Вид. 4те, [перероб. та доп.]/ О.В. Васюренко. - К.: Видавництво "Знання", 2011. - 324 с.

3. Шарова С.В. Визначення проблем іпотечного кредитування в період економічної кризи [Електронний ресурс]/ С.В. Шарова,А.О. Мартищенко// Ефективна економіка: зб. наук. пр., 2016. - № 1. - Режим доступу: http://www.economy.nayka.com.ua/?op $=1 \& z=4722$

4. Андрушків Т. Криза іпотечного кредитування в Україні та шляхи їі подолання / Т. Андрушків // Українська наука: минуле, сучасне, майбутнє. - 2012. - № 16. - С. 3-9.

5. Результати діагностики банків станом на 20.07.2017 [Електронний ресурс]/ Національний банк України. - Режим доступу: https://bank.gov.ua/ control/ $\mathrm{uk} /$ publish/article?art_id=43903211\&cat_id=43915442

References:

1. The Verkhovna Rada of Ukraine (2003), The Law of Ukraine "On Mortgage", available at: http://zakon.rada.gov.ua/laws/show/898-15 (Accessed 15 Oct 2018).

2. Vasiurenko, O.V. (2011), Bankivs'ki operatsii: navchal'nyj posibnyk [Banking Transactions: Teach. Manual], Vydavnytstvo "Znannia", Kyiv, Ukraine.

3. Sharova, S. V. (2016), "Definition of mortgage lending problems during the economic crisis", Efektyvna ekonomika: zbirnyk naukovykh prats', [Online], vol. 1, available at: http://www.economy.nayka.com.ua/?op $=1 \& \mathrm{z}=4722$ (Accessed 15 Oct 2018).

4. Andrushkiv, T. (2012), "The crisis of mortgage lending in Ukraine and ways to overcome it", Ukrains'ka nauka: mynule, suchasne, majbutnie, vol. 16, pp. 3-9.

5. National Bank of Ukraine (2017), "Results of diagnostics of banks", available at: https://bank.gov.ua/ control/uk/publish/article?art_id=43903211\&cat_id=43915442 (Accessed 15 Oct 2015).

Стаття надійила до редакиї 25.10.2018 p. 


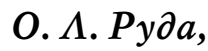
к.е.н., дочент кафедри фінансів, банківськой справи та страхуваннл, Вінницький начіональний аграрний університет, м. Вінниия

К.Г.Маркуш, магістр, кафедри фінансів, банківсъкоӥ справи та страхуваннл, Вінницького начіонального аграрного університету, м. Вінниил

\section{АЕПОЗИТНА ПОЛІТИКА БАНКУ ТА МЕХАНІЗМ IіÏ РЕАЛІЗАЦIÏ}

O. Ruda,

Candidate of economic sciences, associate professor of department of finance banking and insurance, Vinnytsia national agrarian University, Vinnytsya K. Markush, magistr of Department of Finance, Banking and Insurance, Vinnytsia National Agrarian University, Vinnytsya

\section{DEPOSIT POLICY OF THE BANK AND THE MECHANISM OF ITS REALIZATION}

УСтатті висвітлено поняття "вкАад" $і$ "депозит", які ототожнюють, хоча, на думку багатьох економістів, останне поняття є ширшим. Наведено кАасифікаціюдепозитів за різними ознаками. Депозитна політика банку - це сукупність цільових орієнтирів депозитної діяльності банку, що визначають види, умови, обсяги та Структуру депозитних операцій банку, поведінку банку під впливом зовнішніх і внутрішніх факторів, а також вибір найбільш ефективних Способів їх, осягнення, що підпорядковується загальним вимогам щодо діяльності банку, тобто поєднаннюдоходності, Аіквідності й ризикУ.Депозитна політика банку визначає загальну стратегію, положення і обмеження в діядьності банку щодо здійснення депозитних операцій з кАієнтами. Визначення основних СкАадових,депозитної політики може СА Ужити основою для формування методологічних засад ї̈ розроблення Укожному банку, оскільки ці компоненти відображають всі головні аспекти організації,депозитної,діяьності, які мають бути врахованими при здійсненні відповідних операцій.

На практиці у кожному банку така політика повинна охоплювати два такі напрями: по-перше - це формування змісту самої депозитної політики, а по-друге, вона повинна містити конкретні організаційно-управлінські заходи, спрямовані на ї̈ реалізацію. Вихідними моментами для реалізації обидвох напрямів є цілі і завдання депозитної політики, а також ї̈ елементи, визначені відповідно до загальної мети діяльності банку як ринкової фірми, що отримує відображення у належному рівні прибутковості та ліквідності як основних критеріїв функціонування банківської установи.

Аля формування в Україні ефективної ринкової економіки, спроможної на рівних конкурувати з європейськими країнами, потрібна сильна банківська система, яка здатна вирішувати власні питання і Стимулювати розвиток реального сектора економіки. А Аля цього необхідно перейняти європейські стандарти і підходи до роботи. Призначення банківської системи в ринковій економіці полягає в забезпеченні безперервного, збалансованого і стабільного обігу грошей на макро- і мікрорівні відповідно до потреб та інтересів усіх суб'єктів процесу розширеного відтворення. Через регулювання грошового обороту банківська система має змогу ефективно впливати на всі стадї суспільного життя.

This article covers the concept of "deposit" and "deposit" which equates, although, according to many economists, the latter concept is wider. The classification of deposits on various grounds is given. Deposit policy of the bank is a set of target benchmarks of deposit activity of the bank, which determine the types, conditions, volume and structure of deposit operations of the bank, the behavior of the bank under the influence of external and internal factors, as well as the choice of the most effective ways to achieve them, which is subject to the general requirements for the bank's activities, that is, the combination of profitability, liquidity and risk. The 
deposit policy of the bank determines the general strategy, provisions and limitations in the bank's operations on depositary operations with clients. Determining the main components of deposit policy can serve as the basis for the development of methodological principles for its development in each bank, since these components reflect all major aspects of the organization of deposit activity, which should be taken into account in the implementation of the relevant operations.

Ключові слова: депозитна політика, банк, банківські ресурси, залучені кошти, банківські операчії, вклад, ощадні депозити, строкові депозити, прочентна ставка.

Key words: deposit policy, bank, bank resources, funds attracted, banking operations, deposits, savings deposits, term deposits, interest rate. deposit policy, bank, bank resources, funds raised, banking operations, deposits, savings deposits, term deposits, interest rates.

\section{ПОСТАНОВКА ПРОБЛЕМИ У ЗАГАЛЬНОМУ ВИГЛЯДІ ТА ІЇ ЗВ'ЯЗОК ВЗ ВАЖЛИВИМИ НАУКОВИМИ ЧИ ПРАКТИЧНИМИ ЗАВДАННЯМИ}

Питанню формування депозитної політики не приділялося належної уваги. Це було пов'язано з тим, що попит на банківські послуги значно перевищував пропозицію; високий рівень інфляції, наявність дешевих ресурсів, зростання курсу іноземної валюти - усі ці умови забезпечували високу норму прибутку банківських операцій, змінюючи саму природу їх ризику. Виходячи із зазначеного, проблема зумовлена, по-перше, існуючим підвищенням ролі депозитної політики в забезпеченні стійкості комерційного банку, по-друге, необхідністю комплексного дослідження депозитної політики комерційного банку у взаємовідносинах із клієнтами.

\section{АНАЛІЗ ОСТАННІХ ДОСЛІДЖЕНЬ І ПУБЛІКАЦІЙ}

Значний внесок у розробку питань депозитної діяльності банківських установ зробили зарубіжні економісти: Г. Айленбергер, Р. Еллер, П. Роуз, Аж. Сінкі. Серед вітчизняних вчених слід виділити праці О. Васюренка, О. Азюблюка, О. Амітрієва, В. Геєця, А. Герасимовича, О. Гриценка, О. Заруби, А. Кириченка, В. Колеснікова, Т. Коха, $\Lambda$. Кроливецької, А. Мороза, С. Науменкової, $\Lambda$. Примостки, М. Савлука, Т. Смовженко та інших.

\section{ФОРМУЛЮВАННЯ ЦІЛЕЙ СТАТТІ} (ПОСТАНОВКА ЗАВДАННЯ)

Аослідження та аналіз сучасного ринку депозитних послуг, визначення перспектив розвитку депозитних операцій, особливості практичної реалізації.

\section{ВИКЛАД ОСНОВНОГО МАТЕРІАЛУ ДОСЛІДЖЕННЯ}

Наявність достатнього обсягу грошових ресурсів банку, які включають у себе власні кошти і кошти, залучені від інших фізичних та юридичних осіб, - необхідна умова ефективної кредитної діяльності. Від величини і структури джерел формування кредитних ресурсів банків залежить їх фінансова стійкість, надійність, що в свою чергу, є важливим фактором стабільного розвитку банківської системи в цілому.

Аепозити є одним з основних джерел формування ресурсного потенціалу. На сучасному етапі розвитку економіки перед банківськими установами постає проблема залучення коштів населення, що викликана значним відпливом коштів фізичних осіб з банківських рахунків внаслідок падіння довіри до банківської системи України в період кризи.

Переважна частина ресурсів комерційних банків формується за рахунок залучених та позичених коштів, а не власних. Можливості комерційних банків у залученні коштів регулюються НБУ. Так, згідно з показником платоспроможності банку, нормативне значення якого встановлює НБУ, залученні та позиченні кошти не повинні перевищувати розмір власного капіталу більше ніж у 12 разів [1, с. 87$]$.

Банківські установи залучають вільні грошові кошти юридичних та фізичних осіб шляхом виконання депозитних операцій, 3 допомогою яких застосовують різні види банківських рахунків.

Вклад (депозит) — це грошові кошти в національній та іноземній валюті, передані їхнім власником або іншою особою за його дорученням у безготівковій або готівковій формі на рахунок власника для зберігання на певних умовах. Операції, пов'язанні з залученням грошових коштів на вклади, мають назву депозитних.

У деякій літературі поняття "вклад" і "депозит" ототожнюють, хоча, на думку багатьох економістів, останнє поняття є ширшим [2, с. 16]. Зважаючи на наявні формулювання у чинному законодавстві України, терміни "депозит" та "вклад"є тотожними. Так, у Законі України "Про фонд гарантування вкладів фізичних осіб" зазначено, що вклад (депозит) - кошти в готівковій або безготівковій формі у валюті України або в іноземній валюті, які відповідно до законодавства України розміщені вкладником на договірних засадах на визначений строк зберігання або без зазначення такого строку на іменних рахунках у банку - учаснику (тимчасовому учаснику) Фонду гарантування вкладів фізичних осіб чи залучені таким банком у формі випуску (емісії) іменних ощадних (депозитних) сертифікатів і підлягають виплаті вкладнику відповідно до законодавства України та умов договору.

3 метою обліку, аналізу та планування депозитної діяльності банку, депозити класифікуються за багатьма ознаками. В сучасній економічній літературі наводиться досить багато спроб класифікації банківських депозитів, що відрізняються між собою за обсягом інформації, яка надається, ступенем укрупненості та деталізації, які розкривають загальні ознаки цього поняття або мають певну спрямованість. У деяких літературних джерелах $є$ розходження або протиріччя щодо класифікації за тією чи іншою ознакою. Види депозитних рахунків, які використовуються у практиці сучасних банків, $є$ дуже різноманітними, а в результаті появи нових банківських продуктів та різноманітних фінансових нововведень їх кількість протягом останніх років зросла. Таке явище можна пояснити тим, що всі без винятку банки прагнуть максимально задовольнити попит будьяких груп клієнтів на депозитні послуги та залучити їхні заощадження і тимчасово вільні грошові кошти на депозитні рахунки.

Класифікація банківських депозитів повинна визначати відповідні підходи до методів оцінки та аналізу депозитів для прийняття відповідних управлінських рішень щодо здійснення цих операцій, а також ступінь відповідальності за отриманими результатами. Ще однією із цілей класифікації депозитів банків є надання 
Таблиця 1. ТОП-10 рейтингу найбільших банків: депозити фіз. осіб (тис. грн)

\begin{tabular}{|l|l|l|l|}
\hline № & \multicolumn{1}{|c|}{ Банк } & \multicolumn{1}{|c|}{$\begin{array}{c}\text { депозити } \\
\text { фіз. осіб }\end{array}$} & \multicolumn{1}{c|}{$\begin{array}{c}\text { в т.ч. до } \\
\text { запитання }\end{array}$} \\
\hline 1 & Приватбанк & 159561569 & 40457303 \\
\hline 2 & Ощадбанк & 74603999 & 17452423 \\
\hline 3 & Укрексімбанк & 23833267 & 6785572 \\
\hline 4 & Райффайзен Банк Аваль & 18342288 & 12188004 \\
\hline 5 & Альфа-Банк & 17642822 & 3156410 \\
\hline 6 & Укргазбанк & 15603119 & 3688050 \\
\hline 7 & Укрсоцбанк & 15315647 & 4481489 \\
\hline 8 & ПУМБ & 14341302 & 3815535 \\
\hline 9 & Укрсіббанк & 11849687 & 10170287 \\
\hline 10 & ОТП Банк & 9142769 & 6789443 \\
\hline
\end{tabular}

Ажерело: [4].

Таблиця 2. ТОП-10 найбільших банків за депозитами юр. осіб (тис. грн)

\begin{tabular}{|l|l|l|l|}
\hline № & \multicolumn{1}{|c|}{ Банк } & $\begin{array}{c}\text { депозити } \\
\text { юр. осіб }\end{array}$ & \multicolumn{1}{c|}{$\begin{array}{c}\text { в т.ч. до } \\
\text { запитання }\end{array}$} \\
\hline 1 & Ощадбанк & 73932281 & 29167207 \\
\hline 2 & Укрексімбанк & 64568757 & 54224573 \\
\hline 3 & Укргазбанк & 42301361 & 23044684 \\
\hline 4 & Приватбанк & 39875434 & 19827482 \\
\hline 5 & Райффайзен Банк Аваль & 29214610 & 25317936 \\
\hline 6 & Укрсіббанк & 22096360 & 19662901 \\
\hline 7 & Сітібанк & 19071553 & 18537378 \\
\hline 8 & ПУМБ & 18460769 & 12578811 \\
\hline 9 & Креді Агріколь Банк & 18294697 & 10380482 \\
\hline 10 & Альфа-Банк & 13573756 & 5998015 \\
\hline
\end{tabular}

Ажерело: [4].

власнику депозитного рахунку - фізичній чи юридичній особі якнайповнішої інформації з питань зберігання, виплати та отримання процентів за депозитом. Так, наприклад, можна виділити такі види трансакційних депозитів [3, с. 49]:

- строкові вклади на рахунки з автоматичним перерахуванням коштів на поточні рахунки; коштів;

- "ноу" рахунки з випискою наказів про вилучення

- дольові рахунки з випискою переказних векселів.

Класифікація депозитів може бути проведена за різними ознаками. Аепозити розрізняють залежно від строку, умов внеску та вилучення коштів, сплати процентів, можливістю отримання пільг за активними операціями з банком тощо. Найбільш розповсюдженою ознакою класифікації депозитів є їхній поділ у залежності від їх економічного змісту на такі групи:

- депозити до запитання;

- строкові депозити;

- ощадні вклади;

- цінні папери [5, с. 86].

Аепозити до запитання, які у світовій банківській практиці називають трансакційними, - це зобов'язання, які не мають конкретного строку погашення та можуть бути вилучені в будь-який час за першою вимогою вкладника. Ці депозити можуть бути як безпроцентними, так і з виплатою процентів, але, як правило, дуже незначних.

Аепозити на визначений строк (строкові депозити) найтрадиційніший i, як правило, найдохідніший для клієнта вид депозитних послуг. Це грошові кошти, що зараховуються на депозитні рахунки на жорстко обумовлений термін 3 виплатою процентів і можуть бути знятими після закінчення терміну або після попереднього повідомлення банку за встановлений період.

Строкові вклади $є$ джерелом одержання прибутків їх власниками. Вони оформляються угодою між вкладником і банком. Сума, строки та умови оформлення строкових депозитів визначається банком відповідно до його фінансових можливостей за погодженням із вкладником.
У банківській практиці клієнтам пропонуються різноманітні види депозитів: депозити 3 поповненням, які передбачають збільшення суми депозиту в період його зберігання в банку; депозити з пролонгацією, які передбачають продовження строку депозиту; депозити з попереднім повідомленням про вилучення, кошти 3 яких повертаються лише після попереднього повідомлення власника депозитного рахунку у письмовій формі $[6$, c. 140$]$.

Ще одним цікавим депозитним продуктом, який пропонується банками України для фізичних та юридичних осіб є депозитна лінія, при якій сума, строки та процентна ставка при розміщенні конкретних траншів обумовлюються додатково.

Ще одним із найрозповсюдженіших видів банківських депозитів є ощадні депозити. Такі депозити, як правило, розміщуються в банках фізичними особами на тривалі строки. Ощадні депозити - це не чекові вклади, що приносять проценти, які можна терміново вилучати. Основним пріоритетом для власника такого депозиту є заощадження й накопичення коштів та отримання за ними доходів у вигляді сплачених банком процентів.

У квітні - червні 2018 року збереглися високі темпи припливу гривневих коштів населення в банківську систему $(+8,7 \%$ квартал до кварталу $\mathrm{i}+21,4 \%$ рік до року). Аержавні банки продовжували нарощувати обсяги депозитів у валюті, хоча в цілому по системі частка валютних депозитів скорочується. У другому кварталі обсяг коштів населення в банках зросли на 17,2 млрд грн [4].

Аепозити юридичних осіб в банках, після сезонного відтоку на початку року, у другому кварталі збільшилися на 6,4 млрд грн. У цілому, за квітень-червень кошти бізнесу в банках зросли на $0,9 \%$ в гривні і $4,2 \%$ в іноземній валюті в доларовому еквіваленті. При цьому частка коштів НБУ в фондах банків знизилася до історично мінімального значення в $0,9 \%$.

Протягом другого кварталу ставки по гривневих депозитах фізичних осіб і вартість кредитів для населення майже не змінилися, констатували НБУ. Банки слабо диференціюють депозитні ставки в залежності від терміновості: вартість депозитів у гривні на 6, 9 і 12 місяців перебувала на рівні близько $14,1 \%$ річних на кінець кварталу [4].

Вартість 12-місячних депозитів в доларах залишалася на історичному мінімумі - 3,3\% річних. А вартість нових корпоративних кредитів зросла на 0,6 п.п. - до $16,1 \%$ річних.

Проблема формування депозитних ресурсів є дуже важливою в умовах становлення та розвитку банківської системи в Україні, розв'язання якої потребує перегляду чинного механізму депозитної політики для всіх банків без винятку (та його складових - форм і методів), побудови депозитних відносин між банками і клієнтами (суб'єктами господарювання та фізичними особами) відповідно до вимог ринкової економіки, соціально-економічних і політичних цілей розвитку суспільства та сучасної банківської практики (рис. 1).

Разом із тим банки, що акумулюють депозитні ресурси, можуть виступати в ролі учасника депозитного процесу з іншої сторони, розміщуючи кошти на депозити в інших банках та шляхом купівлі депозитних сертифікатів у Національного банку України. Таким чином, у сучасних економічних умовах депозити виконують різні функції, на основі яких формується характер відносин між банками та їх клієнтами з приводу здійснення депозитних операцій.

При здійсненні депозитної діяльності між банком і клієнтами 3 моменту відкриття депозитних рахунків виникають певні взаємовідносини, які перестають діяти лише після закриття рахунку. Взаємовідносини між банком та клієнтами носять добровільний і цільовий характер, не обмежуються сумами та кількістю рахунків у банку. Такі відносини обумовлюються, як правило, в 
депозитній угоді.

Таким чином, відносини, що виникають між банками та їхніми контрагентами з приводу депозитної діяльності, слід розглядати як динамічну, складну економічну категорію, характер якої змінюється під впливом дії суб'єктивних і об'єктивних чинників, а саме: фінансової політики держави, нормативно-законодавчої бази, економічної та політичної ситуації у країні, розвитку фінансово-кредитної інфраструктури, фінансового стану контрагентів, які користуються депозитними послугами банку тощо [8, с. 26].

Успішне функціонування механізму депозитної політики залежить від того, наскільки забезпечується єдність інтересів цих сторін від того, чи мають клієнти тимчасово вільні кошти і чи банки здатні приймати кошти на депозити та повертати їх в кінці обумовленого строку та виплачувати за ними проценти.

Організація депозитної діяльності у кожному банку має свої особливості, що визначаються розмірами, можливостями банку, а також потребами його клієнтів. Аіяльність банків на депозитному ринку повинна передбачати узгоджене функціонування відповідних підрозділів і для його забезпечення в банках створюється спеціальний координаційний орган - Комітет з управління активами і пасивами (КУАП), який у сфері депозитних операцій повинен реалізувати таку мету: формує та розробляє відповідну стратегію та політику; затверджує організаційну структуру процесу роботи з депозитами; встановлює напрями диверсифікації депозитного портфеля банку; знаходження додаткових ресурсів для розширення депозитної діяльності; визначення цінової політики банку за депозитними операціями та послугами банку; аналіз та управління ризикам, що є характерними для операцій банку з депозитами.

Таким чином процес розроблення депозитної політики та практична їі реалізація повинні охоплювати як формування основних напрямів депозитної діяльності банків, так і визначення необхідного ресурсного забезпечення.

\section{ВИСНОВКИ З ПРОВЕДЕНОГО ДОСЛІДЖЕННЯ I ПЕРСПЕКТИВИ ПОДАЛЬШИХ РОЗВІДОК У ЦЬОМУ НАПРЯМІ}

Таким чином, депозитна політика повинна бути взаємопов'язаною із кредитною політикою і забезпечувати реалізацію останньої. Саме такий підхід на сьогодні може забезпечувати ліквідність, фінансову стійкість і одночасно прибутковість банківських установ.

Основними напрямами, що стосуються підвищення ефективності проведення депозитної політики банку є: формування кожним банком власної депозитної політики, виробленої з урахуванням специфіки його діяльності та критеріїв оптимізації цього процесу; розвиток депозитних операцій 3 населенням на основі упровадження нової техніки і технології банківського обслуговування фізичних осіб; забезпечення високої стійкості залучених банком коштів; активне використання процентної політики як методу стимулювання розміщення коштів на різні види депозитів; розширення обсягу термінових депозитів шляхом використання коштів спеціального призначення, які знаходяться на рахунках підприємств; забезпечити захист інтересів вкладників, що дозволить реально підвищити надійність банків та іх здатність виконувати функцію щодо перетворення заощаджень громадян в інвестиції.

Проте істотне підвищення ролі депозитної політики у забезпеченні стійкості і надійності як окремо взятого банку, так і економіки країни зумовлює необхідність подальших комплексних досліджень, особливо механізму взаємодії банківських установ $з$ клієнтами у процесі формування ресурсного потенціалу.
Складові механізму формування та реалізації політики банку

\begin{tabular}{ll}
\hline Організація депозитної діяльності банку \\
\hline Формування депозитних ресурсів банку \\
\hline Методи управління процесом залучення депозитів \\
\hline Моніторинг і контроль \\
\hline Вевіднсини між банками та вкладниками \\
\hline
\end{tabular}

Рис. 1. Складові механізму формування та реалізації депозитної політики банку

\section{$\Lambda$ ітература:}

1. Азаренкова, Г.М. Управління фінансовими ресурсами банку [Текст]: монографія / Г.М. Азаренкова, І.І. Біломістна, В.Г. Сословський. - К.: УБС НБУ, 2012. $-179 \mathrm{c}$.

2. Ковшар А.I. Шляхи удосконалення депозитної політики на сучасному етапі // Фінанси України. - 2009. - № 7. - C. 13-18.

3. Маглаперідзе А. Проблеми та перспективи розвитку депозитного ринку в контексті реалізації депозитної політики комерційними банками // Економіка та держава. - 2008. - № 4. - С. 48-51.

4. Національний Банк України [Електронний ресурс]: офіційний вебсайт - Режим доступу: http:// www.nbu.gov.ua

5. Рисін М.В. Адаптація депозитної політики банків до потреб клієнтів / М.В. Рисін // Вісник університету банківської справи НБУ. - 2009. — № 3 (6). - С. $85-$ 88.

6. Третуб А.В. Тенденції розвитку сучасного ринку депозитів / / Фінанси України. - 2009. - № 10. C. $139-143$.

7. Черкасова С.В. Ринок фінансових послуг [Текст]: навч. посібник / С.В. Черкасова. - $ь$ ьвів: Магнолія 2006, 2011. - $496 \mathrm{c}$.

8. Ярошенко С.П. Управління залученням ресурсів банку з депозитніх джерел [Текст]: монографія / С.П. Ярошенко [та ін.]. - Суми: Університетська книга, 2011. -105 c.

References:

1. Azarenka, G.M. Belomistnaya, I. I. and Sozlovsky, V.G. (2012), Upravlinnia finansovymy resursamy banku [Management of financial resources of the bank], UBS NBU, Kyiv, Ukraine.

2. Kovshar, A.I. (2009), "Ways of improvement of deposit policy at the present stage", Finansy Ukrainy, no 7, pp. 13-18.

3. Magdaliperidze, A. (2008), "Problems and Prospects for the Development of the Deposit Market in the Context of Realization of Deposit Policy by Commercial Banks", Ekonomika ta derzhava, no. 4, pp. 48-51.

4. National Bank of Ukraine (2018), available at: http:/ /www.bank.gov.ua/control/uk/publ ish/category?cat_$\mathrm{id}=57420$ (Accessed 12 October 2018).

5. Risin, M.V. (2009), "Adaptation of deposit policy of banks to customer needs", Visnyk universytetu bankivskoi spravy NBU, no. 3 (6), pp. 85-88.

6. Treutub, D.V. (2009), "Trends in the development of the modern deposit market", Finansy Ukrainy, no. 10, pp. $139-143$

7. Cherkasova, S.V. (2011), Rynok finansovykh posluh [Financial Services Market], Magnolia 2006, Lviv, Ukraine.

8. Yaroshenko, S.P. (2011), Upravlinnia zaluchenniam resursiv banku z depozytnikh dzherel [Management of attraction of bank resources from deposit sources], University's book, Sumy, Ukraine.

Стаття надійила до редакиї 26.10.2018 p. 
A.I. Бровко,

к.е.н., дочент кафедри фінансів, банківської справи та страхуваннл, Аніпровський державний аграрно-економічний університет, м. Аніпро

Ю. В. Сорока, студентка, Аніпровсъкий державний аграрно-економічний університет, м. Аніпро E.I.Бровко, студентка, Аніпровський державний аграрно-економічний університет, м. Аніпро

\title{
АНААІЗ КРЕАИТНОГО ПОРТФЕАЯ КОМЕРЦІЙНИХ БАНКІВ УКРАЇНИ В СУЧАСНИХ УМОВАХ
}

\author{
L. Brovko, \\ PhD in Economics, Associate Professor of the Department of Finance, Banking and Insurance, \\ Dnipro State Agrarian and Economic University, Dnipro \\ Yu. Soroka, \\ student, Dnipro State Agrarian and Economic University, Dnipro \\ Ye. Brovko, \\ student, Dnipro State Agrarian and Economic University, Dnipro
}

\section{ANALYSIS OF THE LOAN PORTFOLIO OF UKRAINIAN COMMERCIAL BANKS IN MODERN CONDITIONS}

\footnotetext{
Кредитування є найважАивішим напрямом здійснюваних банком активних операцій, бо кредитний портфель Становить здебільшого від третини до половини всіх активів банку. УСтруктурі балансу банку кредитний портфель розглядається як єдине ціле та скАадова частина активів банку, що має свій рівень дохідності та ризику. Тому Аля успішного кредитування - забезпечення повернення наданих позичок та підвищення ,охідності кредитних операцій, банки повинні впровадити ефективну та гнучку систему управління кредитним портфелем. Досягнути ж цього можна за допомогою вивчення теоретичних і практичних питань щодо підходів та процесу управління кредитним портфелем комерційного банку.

У роботі було розглянуто теоретичні основи управління кредитним портфелем, зокрема уточнено сутність поняття "кредитний портфель банку" та його роль, враховуючи сучасні ринкові умови, розглянуто підходи до управління кредитним портфелем. Визначено послідовні етапи процесу управління креАитним портфелем комерційного банку. Булодосліджено сутність, функції та етапи розробки кредитної політики банку. Зазначено, що кредитний портфель банку не є простою сумою наданих позичок, а виступає структурованим портфелем активів, що піддається оцінці, сегментації, кАасифікації та управлінню. Проаналізували сучасний стан кредитних портфелів комерційних банків Украйни та визначили фактори, що на них вПливають, також було досліджено динаміку кількості банків в Україні за період 20132017 роки. Обгрунтовано прийоми та заходи захисту від кредитного ризику, які,дають змогу мінімізувати можАиві втрати комерційних банків. Визначили напрями вдосконалення управління кредитним портфелем комерційних банків на основі аналізу сучасного стану банківського кредитування в Україні.
}

Lending is the most important area of active operations carried out by the bank, since the loan portfolio mainly accounts for between a third and a half of all bank assets. In the structure of the bank's balance sheet, the loan portfolio is considered as a whole and a component of assets of the bank, it has its own level of profitability and risk. Therefore, for successful lending - ensuring the repayment of loans provided and increasing the profitability of lending operations, banks must implement an effective and flexible system of loan portfolio management. This can be achieved by studying the theoretical and practical issues of approaches and the process of managing the loan portfolio of a commercial bank.

The paper reviewed the theoretical foundations of credit portfolio management, in particular, clarified the essence of the concept of a bank's loan portfolio and its role, taking into account current market conditions, considered approaches to managing a loan portfolio. The successive stages of the process of managing a credit bank's commercial portfolio were determined. Functions and stages of the development of the credit policy of the bank. It was noted that the loan portfolio of the bank is not a simple sum of granted loans, but rather structurers. 
This portfolio of assets is subject to assessment, segmentation, classification and management. The current state of the loan portfolios of commercial banks in Ukraine has been analyzed and the factors affecting them have been determined, and the dynamics of the number of banks in Ukraine for the period 2013-2017 has been studied. Credit risk to minimize potential losses of commercial banks. Defined ways to improve the management of the loan portfolio of commercial banks based on an analysis of modern state of bank lending in Ukraine.

Ключові слова: банківська діяльність, кредитна діяльність, кредитний портфель комериійного банку, ризик.

Key words: banking, lending, credit portfolio of a commercial bank, risks.

\section{ПОСТАНОВКА ПРОБЛЕМИ У ЗАГАЛЬНОМУ ВИГЛЯДІ ТА ІЇ ЗВ'ЯЗОК ВЗ ВАЖЛИВИМИ НАУКОВИМИ ЧИ ПРАКТИЧНИМИ ЗАВДАННЯМИ}

Економіка України перебуває в умовах фінансовоекономічної нестабільності, тим самим призвела до значних потрясінь у банківській системі та зведення до мінімуму банківського кредитування. В першу чергу це пов'язано з тим, що у зв'язку з нестабільністю законодавчої бази, зниженням довіри населення до банківської системи та багатьма іншими проблемами, банки не можуть балансувати власні витрати на кредитування за рахунок одержаних доходів.

\section{АНАЛІЗ ОСТАННІХ ДОСЛІДЖЕНЬ І ПУБЛІКАЦІЙ}

Аослідженням теоретико-методологічних основ кредитування, аналізу його результатів, а також кредитної політики присвячено багато робіт вітчизняних економістів серед яких: Білик М.А., Вовк В.Я., Жукова Н.К., Зражевська Н.В., Івасіва Б.С., Кузнєцова А.В., Мороз А.П., Савлука М.І., Славюк Р.А., Хмеленко О.В., Юркевич О.М., Шелудько Н.А. та безліч інших.

Проте, незважаючи на велику кількість досліджень, позики повинні постійно аналізуватися в сучасних умовах розвитку країни. Врешті-решт сучасний кредитний аналіз необхідний для управління якістю кредитної діяльності, оскільки кредити $є$ основною частиною активів, також потрібно контролювати стан позики для оцінки економічної ситуації в країні.

\section{ПОСТАНОВКА ЗАВДАННЯ}

Постановка завдання: уточнення сутності, етапів формування, реалізації та аналіз кредитного портфеля комерційних банків в Україні.

\section{ВИКЛАД ОСНОВНОГО МАТЕРІАЛУ ДОСЛІДЖЕННЯ}

Кредитування $€$ найважливішим видом діяльності комерційних банків, оскільки саме від результатів кредитування залежить прибутковість та стійкий фінансовий стан банку. Банківські позики відіграють вагому роль у фінансуванні розвитку ринкової економіки, оскільки вони задовольняють тимчасові потреби деяких підприємств у додаткових фондах через їх тимчасовий надлишок в інших.

Кредитний портфель - це сукупність усіх кредитів, наданих банком для одержання доходів. Обсяг кредитного портфеля оцінюється за балансовою вартістю всіх кредитів банку, у тому числі прострочених, пролонгованих, сумнівних. У структурі банківського балансу кредитний портфель розглядається як складова активів банку, що характеризується показниками дохідності й відповідним рівнем ризику [4].

Управління кредитним портфелем банку було визначено як процес, спрямований на забезпечення раціонального співвідношення дохідності та надійності портфеля. П. Чуб [6] визначає це поняття як процес та поділяє його на п'ять послідовних етапів: вибору кредит- ної політики; аналізу ринку кредитів; формування кредитного портфеля; перегляду кредитного портфеля; оцінки ефективності кредитного портфеля.

Управління кредитним портфелем слід розглядати як процес, що відбувається за такою схемою:

1) формування кредитного портфеля відповідно до існуючих вимог і кредитної політики банку;

2) оцінка сформованого кредитного портфеля щодо дохідності й ризиків, що являє собою не одноразову дію, а постійний моніторинг із виявлення проблемних кредитів та інших недоліків кредитного портфеля;

3) коригування кредитного портфеля, що передбачає підвищення його якості, вирішення питань із проблемними кредитами і включення нових кредитів [3].

Управління кредитним портфелем дає змогу урівноважити і знижувати ризик всього портфеля, контролюючи ризики, властиві певним ринкам, клієнтам, позичковим інструментам, кредитам та умовам роботи.

Аналіз кредитного портфеля вимагає вивчення його структури з точки зору груп ризику, безпеки, структури сектору, власності на позичальників тощо. У сучасних умовах оцінка якості кредитного портфеля комерційного банку залежить від належної оцінки ризику, який банк бере на себе при здійсненні різних операцій. Аля банківського сектору важливо не уникати ризику в цілому, а передбачити та мінімізувати ризик, тобто застосовувати різні методи управління ризиками.

Якісна оцінка кредитного портфеля насамперед спрямована на мінімізацію ризику дефолту за кредитами, що призводить до значних збитків для банків та може призвести до банкрутства.

Аля оцінки його рівня використовуються наступні показники:

— коефіцієнт забезпеченості позики;

- коефіцієнт забезпеченості збитків;

- коефіцієнт захищеності позик від втрат;

- коефіцієнт покриття збитків;

- коефіцієнт покриття позик власним капіталом [1].

Ці показники необхідно аналізувати в динаміці, щоб визначити тенденцію до зміни та причини їх зміни. Розрахунок цих співвідношень дає змогу визначити тенденції фінансового стану та шляхи підвищення економічної ефективності кредитних операцій.

Суть кредитного портфеля також враховується за своїми функціями, у тому числі:

- розподільну та перерозподільну;

- заміщення грошей кредитними операціями;

- об єднання кредитів;

- мінімізації кредитного ризику;

- розширення та диверсифікації дохідної бази банKy.

Основні цілі його утворення походять 3 функцій кредитного портфеля., представлені на рисунку 1 [2].

Якість кредитного портфеля істотно впливає на рівень ризику та надійність банку. У результаті кредитна діяльність регулюється наглядовими органами багатьох країн. Певні обмеження та стандарти, а також пра- 
вила регулювання банківської діяльності відіграють важливу роль у створенні кредитного портфеля.

Залежно від мети банк формує кредитний портфель певного типу. Тип портфеля є характеристика портфеля, яка базується на співвідношенні прибутку та ризику. Основні типи кредитного портфеля наведені на рисунку $2[5]$.

У сучасних умовах трансформації в Україні спостерігається тенденція до зменшення кількості банківських установ. Згідно з офіційними даними Національного банку України, станом на 1 січня 2018 року в Україні зареєстровано 82 банківських установ, що на 14 менше, ніж у попередньому році [7].

У порівнянні з 2013 роком кількість банківських установ зменшилася більш ніж удвічі. Кількість банків з іноземним капіталом та кількість банків з 100\% іноземним капіталом залишається майже на тому ж рівні протягом досліджуваного періоду.

Надання кредитів $є$ найпоширенішою операцією банків. Кредитні операції охоплюють більше 60 \% усіх загальних активів банку (табл. 1).

За останні роки простежується динаміка до збільшення суми наданих кредитів. Але у 2017 році порівняно з 2016 роком збільшення на 4,2\% відбулось лише за рахунок надзвичайного росту обсягу міжбанківських кредитів, оскільки обсяги кредитів фізичним та юридичним особам скоротились.

За даними таблиці 2 видно, що до 2017 року кредити, надані фізичним та юридичним особам, мали тенденцію до збільшення, але за 2017 рік вони зменшились на $11,8 \%$ та $1,9 \%$ відповідно. Це пов'язано з існуючою політичною та економічною ситуацією в Україні.

Платоспроможність українців знизилась, у 2017 році банки вели обережну політику кредитування, ретельніше підбираючи модель оцінки платоспроможності позичальників,що призвело до зменшення обсягів кредитів населенню та суб'єктам господарювання.
Основні цілі формування кредитного портфеля банками

забезпечення максимального рівня дохідності кредитного портфеля та акціонерного капіталу банку за допустимого рівня ризику

забезпечення зваженого та оптимального використання кредитних

досягнення оптимального балансу між зростанням обсягу кредитного портфеля та темпами покращання його якості

розширення клієнтської бази шляхом підвищення якості кредитного обслуговування клієнтів

Рис. 1. Основні цілі формування кредитного портфеля

\begin{tabular}{|c|c|}
\hline \multicolumn{1}{|c|}{ Тип портфеля } & \multicolumn{1}{c|}{ Характеристика } \\
\hline Портфель доходу & $\begin{array}{l}\text { Портфель орієнтовано на кредити, що } \\
\text { забезпечують стабільний дохід, отримання } \\
\text { якого характеризується мінімальними } \\
\text { ризиками та постійною своєчасною } \\
\text { виплатою відсотків }\end{array}$ \\
\hline Портфель ризику & $\begin{array}{l}\text { Портфель складається переважно з кредитів } \\
\text { iз високим рівнем ризику }\end{array}$ \\
\hline 3балансований & $\begin{array}{l}\text { Портфель є раціональним поєднанням } \\
\text { кредитів різного типу як } \\
\text { високоризикованих, так і кредитів } \\
\text { iз низьким рівнем ризику }\end{array}$ \\
\hline
\end{tabular}

\section{Рис. 2. Основні типи кредитного портфеля}

Загальна сума кредитів, наданих комерційними банками збільшилась більш ніж на 23\%, але насправді, якщо враховувати рівень інфляції та зміну валютного курсу за цей період, то ситуація відкривається з іншого боку.

Основні чинники, які впливають на зміну курсу $є$ інфляція, стан платіжного балансу, ступінь використання валюти на міжнародних валютних ринках і в міжна-

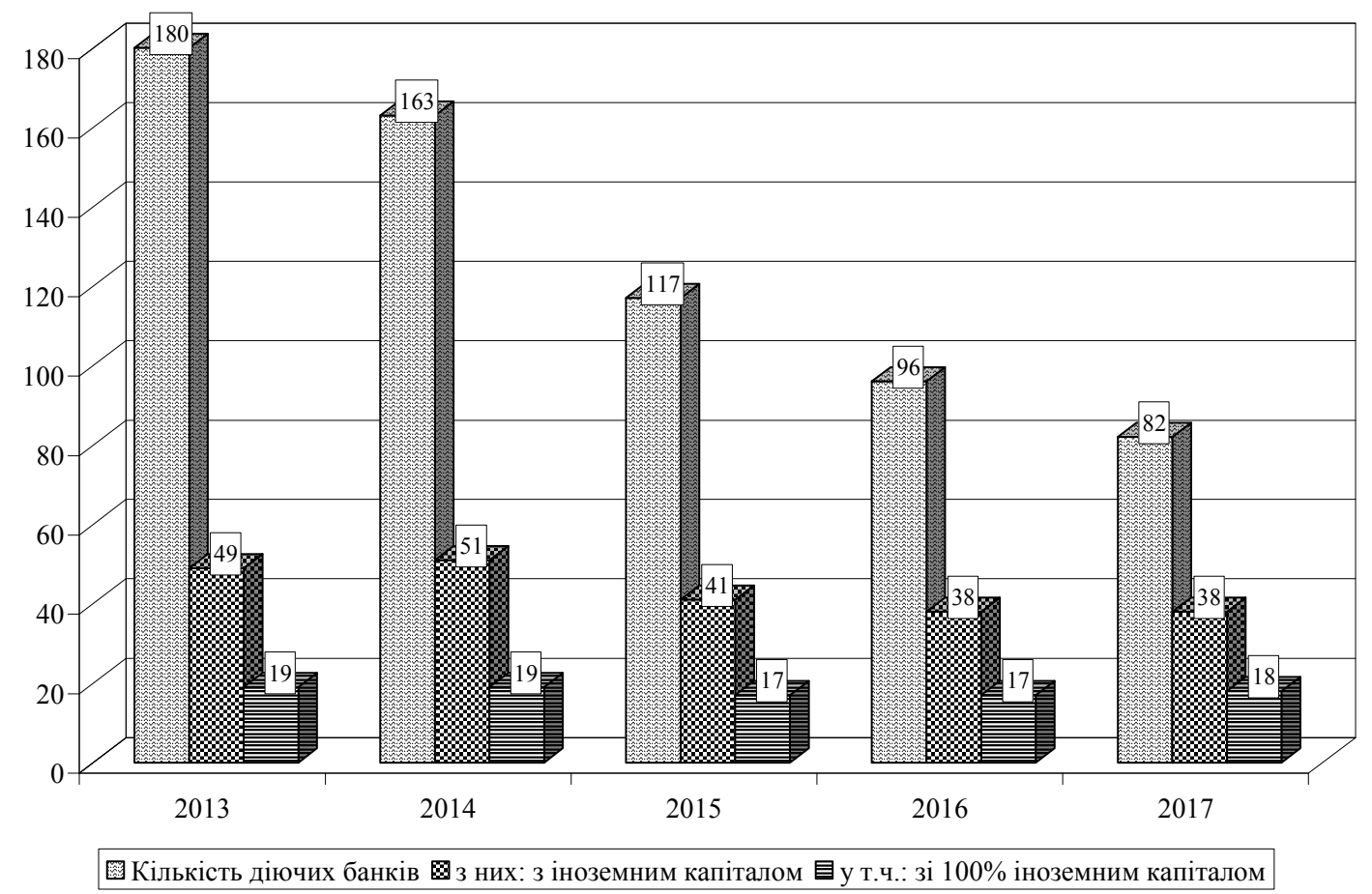

Рис. 3. Динаміка кількості банків в Україні 
Таблиця 1. Частка кредитного портфеля в активах банків України

\begin{tabular}{|l|l|l|l|l|l|}
\hline \multicolumn{1}{|c|}{ Показник } & \multicolumn{1}{c|}{2013 p. } & \multicolumn{1}{c|}{2014 p. } & \multicolumn{1}{c|}{2015 p. } & \multicolumn{1}{c|}{2016 p. } & \multicolumn{1}{c|}{2017 p. } \\
\hline Активи, млн грн & 1278095 & 1316852 & 1254385 & 1256299 & 1336358 \\
\hline Кредитний портфель, млн грн & 911402 & 1006358 & 1009768 & 1005923 & 1042798 \\
\hline $\begin{array}{l}\text { Частка кредитного портфеля в } \\
\text { активах, \% }\end{array}$ & 71,31 & 76,42 & 80,50 & 80,07 & 78,03 \\
\hline
\end{tabular}

Ажерело: розраховано за даними НБУ [7].

родних розрахунках, показники економічного росту країни, валютна політика держави.

Ао 2014 р. валютний курс був стабільним, але вже 3 2014 р. розпочинається стрімке зростання курсу іноземної валюти по відношенню до гривні, і вже станом на початок 2018 р. валютний курс зріс більш ніж на $300 \%$ в порівнянні 32014 р. Рівень інфляції за цей же період склав $13,70 \%$. Тобто зростання вартості виданих кредитів знецінюється.

Реальну тенденцію кредитування характеризують короткострокові кредити, одержані з метою оперативного забезпечення банківської системи ресурсами, дотримання вимог економічних нормативів, підтримки ліквідності, платоспроможності та стабільності функціонування банків. Такий інструмент грошового ринку $€$ найбільш реальною можливістю підтримки ліквідності банківських балансів, поповнення коррахунків і для проведення активних операцій на інших більш дохідних сегментах фінансового ринку. За п'ять років сума міжбанківських кредитів зменшилась майже на третину.

У загальній вартості виданих кредитів, за останні 5

Таблиця 2. Динаміка складу кредитного портфеля комерційних банків України за 2013-2017 pp.

\begin{tabular}{|l|l|l|l|l|l|l|}
\hline \multicolumn{1}{|c|}{ Показники } & 2013 p. & 2014 p. & 2015 p. & 2016 p. & 2017 p. & $\begin{array}{c}2017 \text { p. } \\
\text { y до } \\
2013 \text { p. }\end{array}$ \\
\hline Кредити надані, млрд грн & & & & & & \\
\hline у \% до попереднього року & 815 & 911 & 1006 & 1117 & 1006 & 123,44 \\
\hline Кредити юридичним особам, млрд грн & - & 111,8 & 110,4 & 111,03 & 90,06 & - \\
\hline у\% до попереднього року & - & 540 & 639 & 863 & 847 & 163,19 \\
\hline Кредити фізичним особам, млрд грн & 127 & 104,0 & 118,3 & 135,1 & 98,1 & - \\
\hline у \% до попереднього року & - & 109,4 & 109,4 & 117,1 & 88,2 & - \\
\hline Міжбанківські кредити, млрд грн & 169 & 232 & 215 & 76 & 112 & 66,27 \\
\hline у \% до попереднього року & - & 137,3 & 92,7 & 35,3 & 147,4 & - \\
\hline
\end{tabular}

Ажерело: розраховано за данними НБУ [7]. років значно зменшилась доля міжбанківських кредитів, але спостерігається незначне підвищення у порівнянні 3 попереднім роком. А це вже хороша тенденція

Розглянемо динаміку структури кредитного портфеля на рисунку 4.

За офіційними даними НБУ на 01.03.2018 р., доля проблемних кредитів в обсязі кредитів, наданих юридичним особам, $58 \%$, а в обсязі кредитів, виданих фізичним особам, $55 \%$. Найбільше проблемних кредитів виданих фізичним та юридичним особам у державних банках - близько $72 \%$. Навіть якщо не враховувати АТ КБ "ПриватБанку" в державних банках загалом $58 \%$ проблемних кредитів. Частка таких кредитів у банків з іноземним капіталом $44 \%$, і тільки у банків, де приватні власники з України, доля таких кредитів становить 24\%. Виходить, що українські банки 3 приватним капіталом, виявилися найбільш результативними, на відміну від державних банків, які фактично спонукають банківську систему до краху.Ао початку реформ частка проблемних кредитів не перевищувала $10 \%$, а тепер рівень проблемних кредитів у прямому сенсі критичний і не поспішає знижуватися.

Банківська сфера як жодна інша пов'язана з високою ризиковістю. Оскільки кредити $є$ найприбутковішими банківськими активами, то ризик, особливо кредитний, - це складова частина діяльності комерційних банків.

Кредитування в інших країнах пов'язане із істотним кредитним ризиком, але він вимірюється дещо в інших масштабах. У світовій практиці майбутнє банку, частка прострочених (понад 90 днів) кредитів якого наближається до $7 \%$ від загального обсягу, є досить проблемним. Аля надійних банків цей показник становить близько $3 \%$. Аля вітчизняної банківської системи значення аналогічних показників коливаються в широкому діапазоні: від 2 до $30 \%$.

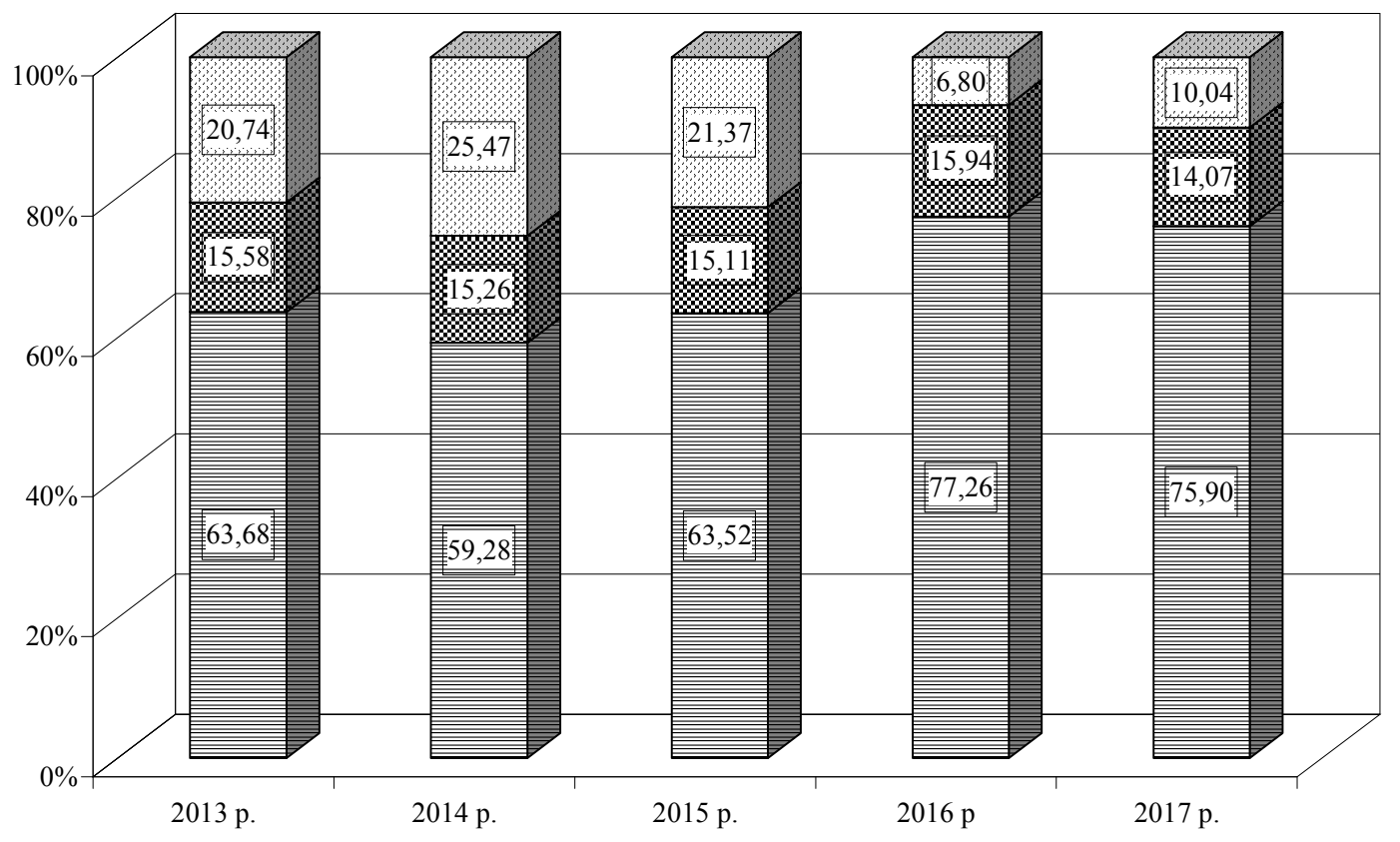

目 Кредити юридичним особам $\mathbf{8}$ Кредити фізичним особам 영 Міжбанківські кредити

Рис. 4. Динаміка структури кредитного портфеля, \% 
У зарубіжній практиці кредитний ризик відноситься до можливого зменшення прибутку банку або втрати власних коштів через неможливість погашення та управління позикою, отриманою позичальником. Іноземні банки використовують спеціальні методи кредитного ризику для оцінки кредитного ризику, що є сукупністю оціночних показників кредитоспроможності позичальника. Вони характеризуються складністю та порівнянністю всіх факторів кредитного ризику.

Англійські клірингові банки здійснюють оцінку потенційного ризику неплатежу по кредиту із використанням методик "PARSEL" і "CÁMPARI".

Методика "PARSEL" включає:

- P (Person) - інформація про персону потенційного позичальника, його репутація;

- A (Amount) - обгрунтування суми затребуваного кредиту;

- R (Repayment) - здатність анулювання;

- S (Security) - оцінка виконання;

- E (Expediensly) - доцільність позики;

- R (Remuneration) - відшкодування відсотків банку за ризик надання кредиту.

Методика "CAMPARI" більш розширена в системі оцінки:

- C (Character) - репутація позичальника;

- A (Ability) - оцінка бізнесу позичальника;

- M (Means) - перевірка необхідності звертання за кредитом;

- P (Pиrpose) - ціль кредиту;

- A (Amount) - обгрунтування мети кредиту;

- R (Repaiment) - cпроможність виплати;

- I (Insurance) - спосіб страхування кредитного ризику.

У практиці американських банків застосовують "правило п'ятьох сі":

- 1 C (customer`s character - характер позичальника) - репутація позичальника, ступінь відповідальності, готовність і бажання сплатити борг;

- 2 C (capacity to pay - фінансові можливості) припускає ретельний аналіз доходів і витрат позичальника і перспективи їхнього розвитку в майбутньому;

- 3 C (capital) - капітал, майно;

- 4 C (collateral) - забезпечення позики, достатність, якість і ступінь реалізовуваної застави у випадку непогашення кредиту;

- 5 C (current business conditions and goodwill - загальні економічні умови) - визначають діловий клімат у країні і впливають на становище банку і позичальника.

Перераховані критерії "сі" іноді доповнюють шостим критерієм - 6 C (control) - моніторинг законодавчих основ діяльності позичальника і відповідність його стандартам банку.

Оптимально використовуючи дані методики, зарубіжні банки мінімізують кредитний ризик, чітко організовують кредитний процес, домагаючись найкращої якості кредитного портфеля.

\section{ВИСНОВКИ}

Незважаючи на загострення ситуації в країні у зв'язку з економічною кризою, підвищенням обмінного курсу національно валюти, зростання інфляції, та у зв'язку з надзвичайними внутрішніми проблемами, банки все одно роблять все можливе для покращення управління кредитним портфелем.

Процес управління кредитним портфелем банку призначений для забезпечення максимального прибутку на певний рівень ризику. При оцінці кредитного ризику доцільно розділити кредитний ризик на рівні транзакції та кредитний ризик на рівні портфеля банку. При управлінні кредитним портфелем, аналіз структури активів є обов'язковою умовою. Зрештою, це залежить від складу кредитного портфеля, його ефективності та прибутковості. Аля покращення якості кредитного портфеля банку необхідно:
— провести розумну кредитну політику України, в якій сума кредитний портфеля не перевищує $35-50 \%$ активів банку;

- постійно контролювати банки, які здійснюють агресивну кредитну політику на банківському ринку, тобто більше $80 \%$ активів знаходиться в кредитному портфелі. На нашу думку, вони знаходяться під загрозою, особливо в періоди нестабільності.

- розробляти та суворо дотримуватися положень основної грошово-кредитної політики з урахуванням зовнішніх та внутрішніх чинників, що впливають на роботу банку;

- забезпечити ефективний моніторинг фінансового стану позичальника для контролю динаміки сумнівних боргів у банку;

- переоцінити кредитний портфель за реальною вартістю (на ринку);

- комерційні банки повинні ретельно підбирати зовнішнього аудитора для запобігання шахрайству та запобігання асоціації аудитора особи з банком.

\section{Мітература:}

1. Аналіз банківської діяльності: підручник / А.М. Герасимович, М.А. Алексеєнко, I.М. Парасій-Вергуненко та ін. / За ред. А.М. Герасимовича. - К.: КНЕУ, 2004. 599 c.

2. Вовк В.Я., Хмеленко О.В. Кредитування і контроль: навч. посіб. / В.Я. Вовк, О.В. Хмеленко. - К.: Знання, 2008. - $463 \mathrm{c}$.

3. Жукова Н.К., Зражевська Н.В. Сучасний стан та проблеми управління кредитним портфелем комерційних банків / Н.К. Жукова, Н.В. Зражевська // Економічний часопис-XXI. - 2013. - № $1-2$ (1). - 71 с.

4. Примостка $\Lambda . О$. Фінансовий менеджмент у банку: підручник / М.О. Примостка. - К.: КНЕУ, 2004. $468 \mathrm{c}$.

5. Степаненко К.Р. Особливості формування кредитного портфеля банку / K.P. Степаненко // Науковий вісник Ужгородського національного університету - 2016. - № 7. - С. 169.

6. Чуб П.М. Нетрадиційний підхід управління кредитним портфелем комерційного банку (практика) / П.М. Чуб // Ринок цінних паперів України.— 2003. № 7-8. - С. 55-61.

7. Грошово-кредитна статистика НБУ// Офіційний сайт Національного банку України [Електронний ресурс]. - Режим доступу: https://bank.gov.ua/control/ $\mathrm{uk} /$ publish/

\section{References:}

1. Herasymovych, A. M. Alekseyenko, M. D. and Parasiy-Verhunenko, I. M. (2004), Analiz bankivs'koyi diyal'nosti [Analysis of banking activity], KNEU, Kyiv, Ukraine.

2. Vovk, V.Ya. and Khmelenko, O.V. (2008), Kredytuvannya i kontrol' [Lending and control], Znannya, Kyiv, Ukraine.

3. Zhukova, N.K. and Zrazhevs'ka, N.V. (2013), "Current state and problems of management of the credit portfolio of commercial banks", Ekonomichnyy chasopysXXI, vol. $1-2(1)$, p. 71.

4. Prymostka, L.O. (2004), Finansovyj menedzhment u banku [Financial management at the bank], 2-nd ed., KNEU, Kyiv, Ukraine.

5. Stepanenko, K. R. (2016), "Features of forming a loan portfolio of the bank", Naukovyy visnyk Uzhhorods'koho natsional'noho universytetu, vol. 7 .

6. Chub, P. M. (2003), " Non-traditional approach to managing a commercial bank's loan portfolio (practice)", Rynok tsinnykh paperiv Ukrainy, vol. 7-8, pp. 55-61.

7. National Bank of Ukraine (2018), "Monetary and credit statistics of the NBU", available at: https:// bank.gov.ua/control/uk/publish/ (Accessed 30 Oct 2018). Стаття надійшла до редакиіï 07.11.2018 p. 
УАК 65.011

E.O.Аіденко,

к.е.н., дочент кафедри менеджменту,

Київсъкий начіональний університет технологій та дизайну, м. Киӥв

А.С.Фесюн,

магістр, Киїьсъкий начіональний університет технологій та дизайну, м. Киїь

DOI: $10.32702 / 2306-6806.2018 .11 .90$

\title{
ТЕОРЕТИКО-МЕТОАИЧНІ ЗАСААИ АНТИКРИЗОВОГО УПРАВЛІННЯ ПІАПРИЕМСТВАМИ
}

\author{
E. Didenko, \\ Ph.D., associate professor of management department, Kyiv National University of Technology and Design, Kyiv \\ A. Fesiun, \\ master's degree, Kyiv National University of Technology and Design, Kyiv
}

\section{THEORETICAL AND METHODOLOGICAL PRINCIPLES OF ANTI-CRISIS MANAGEMENT OF ENTERPRISES}

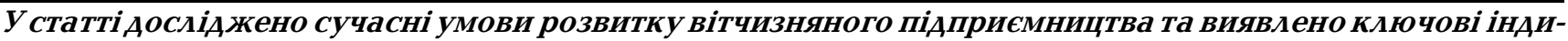
катори загальнонаціонального рівня, що обумовлюють кризові тенденції здійснення підприемСтвами господарської діяльності та розвитку як промисловості зокрема, так і економіки Україні загалом. Задля цього було досліджено динаміку внутрішнього валового продукту країни, розглянуто зміну індексів СПоживчих цін, цін виробників продукції, реальної заробітної платні, обсягів промиСлового виробництва, а також тенденції зміни кількості суб'єктів господарювання за основними видами економічної діяльності, пов'язану 3 цим структурну статистику та тенденції результатів їх функціонування протягом 20122017 років. У роботі вСтановлено основні ознаки кризи як економічного явища, а також виявлено особливості антикризового управління підприємства як специфічної скАадової менеджменту виробничо-комерційної системи. На основі, досліджених теоретико-методичних засад антикризового менеджменту у статті розроблено принципову модель механізму антикризового управління підприємством, що розкриває Сутність кАючових етапів цього процесу, його основні цілі та СкАадові задАя їх, Асягнення. Окрім того, визначено особливу роль в процесі антикризового управління, Сутність якого визначається рівнем кризових проявів, створення конкурентних переваг та забезпечення конкурентоспроможності підприемства, що має Створити потенціал дАя формування рівнів його економічного захисту У майбутньому. Також У роботі з урахуванням з урахуванням доробок у цій сфері управлінської науки сформовано суб'єктовофункціональну схему антикризового управління, яка демонструє особливості діяльності керівництва підприємства в контексті попередження та протидії потенційним та фактичним загрозам його сталому розвитку. Окрім того, вСтановлено принципову Ситуаційність виконання управлінСьких функцій, що залежатиме від типу обраної суб'єктом антикризового управління стратегії та тактики.

In this article the modern conditions of development of domestic business are investigated and the key indicators of the national level are determined, which determine the crisis tendencies of the enterprises of economic activity and development of both industry in particular and the economy of Ukraineas a whole. For this purpose, the dynamics of the gross domestic product of the country was in vestigated, changes in consumer price indices, producer prices, real wages, volumes of industrial production, as well as trends in the number of subjects of management in the main types of economic activity, related structural statistics and trends in the results of their functioning during 2012-2017. The paper identifies the main features of the crisis as an economic phenomenon, as well as identifies the features of the crisis management of the enterprise as a specific component of the management of the production and commercial system. On the basis of the investigated theoretical and methodological principles of anti-crisis management, the article develops the basic model of the mechanism of crisis management of the enterprise, which reveals the essence of the key stages of this process, its main goals and components for their achievement. In addition, a special role in the process of crisis management is determined, the essence of which is determined by the level of crisis manifestations, the creation of competitive advantages and ensuring the competitiveness of the enterprise, which should create the potential for formation of levels of its economic protection in the future. Also in the work, taking into account the achievements in this 
area of management science, a subject-functional scheme of crisis management has been formed that demonstrates the peculiarities of the management's activities in the context of prevention and counteraction to the potential and actual threats to its sustainable development. In addition, the principle situation of the implementation of managerial functions is determined, which will depend on the type of anti-crisis management strategy and tactics chosen by the subject.

Ключові слова: криза, загроза, тендениія, економічна безпека, антикризове управління, стратегія, тактика.

Key words: crisis, threat, trend, economic security, anti-crisis management, strategy, tactics.

\section{ПОСТАНОВКА ПРОБЛЕМИ}

На сьогоднішній день стан економіки України можна охарактеризувати як кризовий, що підтверджує низка тенденцій. Так, не дивлячись на те, що у порівнянні 3 2010 р. у 2017 р. ВВП країни зросло на $175,5 \%$ (рис. 1), тенденція $є$ певною мірою негативною, оскільки у валютному контексті показник на кінець періоду дослідження є істотно нижчим ніж на його початку (рис. 2) [10].

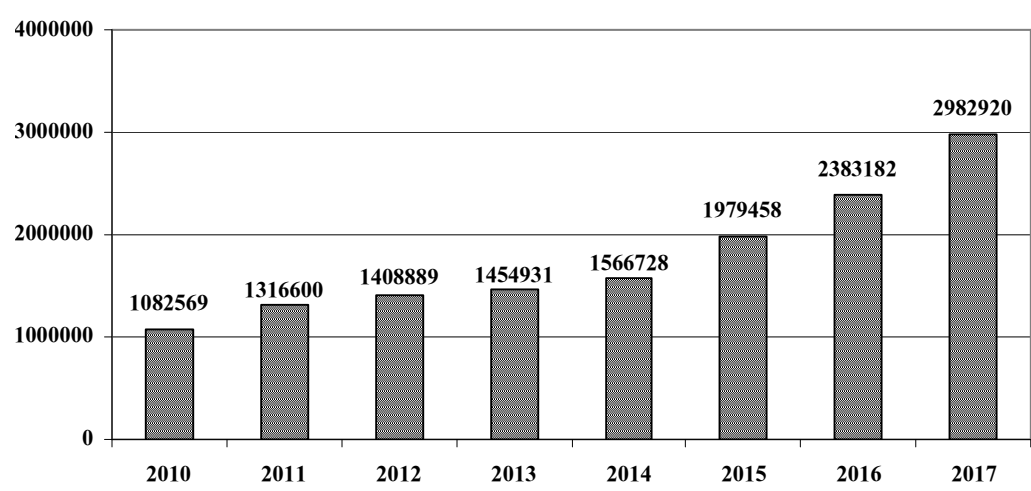

Рис. 1. Динаміка ВВП України за період 2010-2017 рр., млн грн

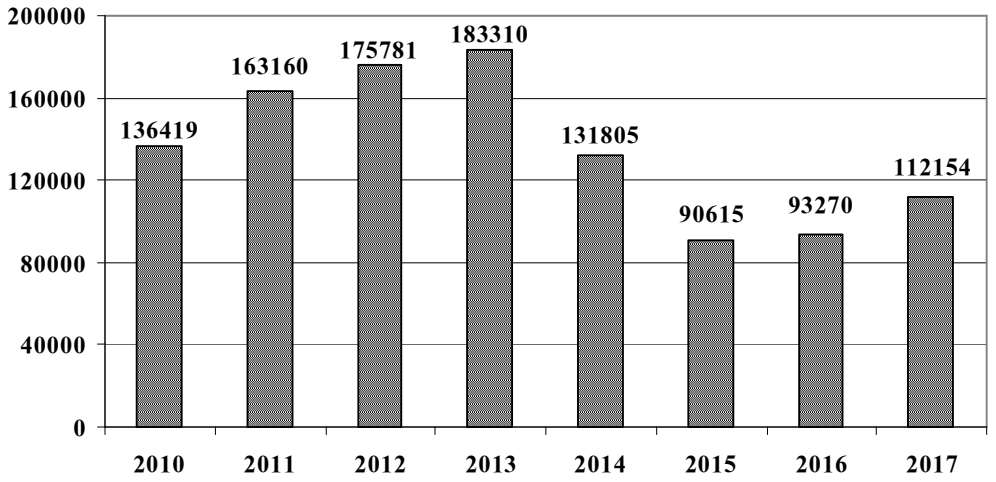

Рис. 2. Динаміка ВВП України за період 2010-2017 рр., млн долл.

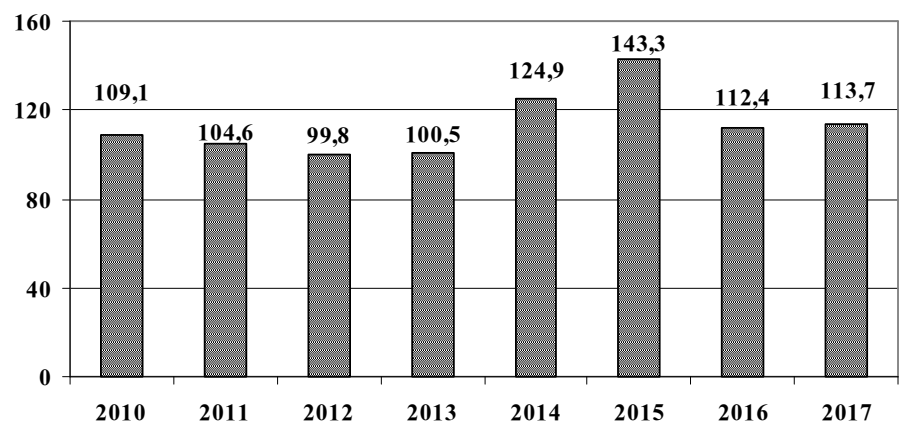

Рис. 3. Динаміка індексу споживчих цін за період 2010-2017 рр., \%
Ключові проблеми, що спричинили падіння національної економіки певною мірою, як відомо, знаходяться у політичній сфері. Але не можна забувати про ключові аспекти, які криються у недостатньому рівні економічної безпеки держави, що формувалися протягом всього періоду незалежності. Загалом це підтверджує динаміка індексу споживчих цін, як ключової характеристики не лише інфляційних процесів, а і певного індикатора низької еластичності економічної безпеки країни (рис. 3) [10].

Окрім того, на увагу заслуговує порівняння індексів цін виробників та реальної заробітної платні, зіставлення яких дозволяє узагальнено охарактеризувати баланс між пропозицією та купівельною спроможністю споживачів. У цьому випадку (рис. 4) [10] динаміку варто відзначити, як деструктивну, оскільки зростання останньої істотною мірою не відповідає вимогам ринків.

Також негативним аспектом, що виступає ознакою кризових тенденцій розвитку України та характеризує загальне погіршення їі економічної безпеки є рівень виробництва (рис. 5) [10], оскільки саме на вітчизняну промисловість припадає ключова роль у формуванні ВВП держави.

У свою чергу, доцільно розглянути динаміку зміни кількості суб'єктів господарювання за видами економічної діяльності, що дозволить зробити висновок про загальну сприятливість умов ведення бізнесу та спроможність бізнесу до виживання в наявних умовах (табл. 1) $[10]$.

Як бачимо, протягом останніх років, яким притаманні очевидні кризові ознаки, спостерігається невтішна тенденція до зменшення кількість суб'єктів господарювання у порівнянні з 2015 р. Причини цього криються: поперше, у промисловості та торгівлі, де відмічаються скорочення споживчої купівельної спроможності та зростання витратності виробничої діяльності; по-друге, у транспортній сфері та складському господарстві, що істотною мірою залежать від вартості енергетичних носіїв; по-третє, у фінансовій та, як наслідок, науково-технічній діяльності, що пов'язано 3 погіршенням інвестиційного клімату, відтоком іноземного капіталу та збільшенням розриву між підприємницьким на науковим секторами тощо.

Поглянувши на показники структурної статистики (табл. 2) [10], очевидним є скорочення кількості великих та середніх підприємств, що $є$ основою формування економіки розвинених країн, а також посилення подрібненість вітчизняного підприємництва. Такі зміни спричинили зменшення частки обсягів доходності великих та певне збільшення долі малих підприємств у загальній структурі. 


\section{ЕКОНОМІЧНА НАУКА}

Однією з головних ознак кризовості національ- 160 ної економіки окрім скорочення кількості суб'єктів господарювання на ринках виступають результати їх функціонування (табл. 3) [10].

Наведені вище матеріали надають можливість констатувати збитковість низки видів економічної діяльності, що не могло не вплинути на рівень економічної безпеки країни загалом.

Все це дозволяє повною мірою стверджувати про наявність кризових тенденцій розвитку держави та констатувати необхідність акцентування уваги на актуальності антикризового управління як на рівні економіки України загалом, так і за окремо взятими підприємствами зокрема.

\section{АНАЛІЗ ОСНОВНИХ ДОСЛІДЖЕНЬ І ПУБЛІКАЦІЙ}

Розробці наукових засад у сфері антикризового управління присвячені роботи великої кількості вітчизняних і закордонних вчених, серед яких А. Балашов, С. Бєляєва, І. Бланк, В. Василенко, О. Вишневська, О. Глушко, А. Гончарук, А. Градов, Т. Гринько, А. Грязнова, О. Єлець, С. Ільїн, $\Lambda$. Каліна, В. Коваленко, $\Lambda$. Коротков, Е. Короткова, В. Кошкіна, І. Кривов'язюк, О. Крухмаль, $\Lambda$. Аігоненко, А. Маринюк, Е. Мінаєв, В. Панагушин, С. Рамазанов, $\Lambda$. Ситник, О. Скібіцький, $\Lambda$. Ситник, О. Терещенко, М. Федотова, А. Чернявський, 3. Шершньова, А. Штангрет та ін. Однак існують дискусійні питання щодо реалізації механізму антикризового управління підприємства та особливостей пов'язаних 3 цим дій менеджменту суб'єкту господарювання, що і обумовлює актуальність теми.

\section{ПОСТАНОВКА ЗАВДАННЯ}

Мета дослідження полягає у розробці комплексу заходів щодо розвитку теоретико-методичних засад 3 антикризового управління вітчизняним підприємством в сучасних умовах.

ВИКЛАД ОСНОВНОГО МАТЕРІАЛУ

Як відомо, термін "криза" застосовується в різних науках, зокрема політиці, економіці тощо. При цьому у процесі розвитку наукових досліджень дане поняття набувало більш глибокого змістовного значення та розповсюдження.

Представимо матеріали щодо трактування деякими 3 науковців сутності терміну "криза" (табл. 4).

Аналізуючи наведені визначення, варто зауважити, що криза є переломною подією, для якої характерна зміна параметрів системи, що викликається як зовнішніми, так і внутрішніми факторами. Ці зміни зазвичай мають негативний характер, несуть загрозу існування суб'єкту ринку і $є$ складно контрольованими, але можуть виступати і ознакою переходу підприємства до нового етапу розвитку. Відповідно, до цього варто виділити два основних результату прояву кризи - оптимізація у разі здатності системи до адаптації або її руйнація у протилежному випадку.

Аискусійним же, на наш погляд, залишається раптовість кризи. Так, дійсно, темпи проявів окремих кризових явищ є різними, але їх симптоматика може бути відстежена за допомогою використання різного методичного інструментарію антикризового управління, що дозволить встановити негативні тенденції розвитку.

Таблиця 1. Результати визначення індексу кількість суб'єктів господарювання за видами економічної діяльності за період 2012-2017 рp.

\begin{tabular}{|c|c|c|c|c|c|c|}
\hline \multirow{2}{*}{ Вид економічної діяльності } & \multicolumn{6}{|c|}{ Роки } \\
\hline & 2012 & 2013 & 2014 & 2015 & 2016 & 2017 \\
\hline \multirow[t]{2}{*}{ Загалом } & 1600127 & 1722070 & 1932161 & 1974439 & 1865631 & 1805144 \\
\hline & & 107,6 & 112,2 & 102,2 & 94,5 & 96,8 \\
\hline \multirow{2}{*}{$\begin{array}{l}\text { - сільське, лісове та рибне } \\
\text { господарство }\end{array}$} & 68497 & 71058 & 75660 & 79284 & 74620 & 76593 \\
\hline & & 103,7 & 106,5 & 104,8 & 94,1 & 102,6 \\
\hline \multirow[t]{2}{*}{ - промисловість } & 114028 & 121244 & 131491 & 135149 & 127069 & 123876 \\
\hline & - & 106,3 & 108,5 & 102,8 & 94,0 & 97,5 \\
\hline \multirow[t]{2}{*}{ - будівництво } & 50830 & 52982 & 52189 & 55128 & 50208 & 50261 \\
\hline & - & 104,2 & 98,5 & 105,6 & 91,1 & 100,1 \\
\hline \multirow{2}{*}{$\begin{array}{l}\text { - оптова та роздрібна } \\
\text { торгівля }\end{array}$} & 843075 & 890658 & 988694 & 989064 & 910413 & 837797 \\
\hline & - & 105,6 & 111,0 & 100,0 & 92,0 & 92,0 \\
\hline \multirow{2}{*}{$\begin{array}{l}\text { - транспорт, складське } \\
\text { господарство, поштова та } \\
\text { кур'єрська діяльність }\end{array}$} & 87252 & 92366 & 111807 & 119037 & 109334 & 95815 \\
\hline & - & 105,9 & 121,0 & 106,5 & 91,8 & 87,6 \\
\hline \multirow{2}{*}{$\begin{array}{l}\text { - тимчасове розміщування й } \\
\text { організація харчування }\end{array}$} & 44085 & 52077 & 57553 & 58436 & 57696 & 57578 \\
\hline & - & 118,1 & 110,5 & 101,5 & 98,7 & 99,8 \\
\hline \multirow{2}{*}{$\begin{array}{l}\text { - інформація та } \\
\text { телекомунікації }\end{array}$} & 66568 & 86377 & 114355 & 116136 & 129704 & 146909 \\
\hline & - & 129,8 & 132,4 & 101,6 & 111,7 & 113,3 \\
\hline \multirow{2}{*}{$\begin{array}{l}\text { - фінансова та страхова } \\
\text { діяльність }\end{array}$} & 10342 & 11069 & 11888 & 12381 & 11865 & 10290 \\
\hline & - & 107,0 & 107,4 & 104,1 & 95,8 & 86,7 \\
\hline \multirow{2}{*}{$\begin{array}{l}\text { - операції з нерухомим } \\
\text { майном }\end{array}$} & 81726 & 92013 & 97794 & 94077 & 90921 & 90553 \\
\hline & & 112,6 & 106,3 & 96,2 & 96,6 & 99,6 \\
\hline \multirow{2}{*}{$\begin{array}{l}\text { - професійна, наукова та } \\
\text { технічна діяльність }\end{array}$} & 87431 & 97052 & 115123 & 131035 & 125133 & 121546 \\
\hline & & 111,0 & 118,6 & 113,8 & 95,5 & 97,1 \\
\hline \multirow{2}{*}{$\begin{array}{l}\text { - діяльність у сфері } \\
\text { адміністративного та } \\
\text { допоміжного } \\
\text { обслуговування }\end{array}$} & 38769 & 40191 & 44144 & 47361 & 45988 & 46553 \\
\hline & & 103,7 & 109,8 & 107,3 & 97,1 & 101,2 \\
\hline \multirow[t]{2}{*}{ - освіта } & 7317 & 8467 & 10117 & 10873 & 11077 & 11656 \\
\hline & - & 115,7 & 119,5 & 107,5 & 101,9 & 105,2 \\
\hline \multirow{2}{*}{$\begin{array}{l}\text { - охорона здоров'я та } \\
\text { надання соціальної } \\
\text { допомоги }\end{array}$} & 16479 & 18048 & 21114 & 21683 & 21583 & 22085 \\
\hline & - & 109,5 & 117,0 & 102,7 & 99,5 & 102,3 \\
\hline \multirow{2}{*}{$\begin{array}{l}\text { - мистецтво, спорт, розваги } \\
\text { та відпочинок }\end{array}$} & 9238 & 11620 & 13523 & 14887 & 13873 & 13045 \\
\hline & & 125,8 & 116,4 & 110,1 & 93,2 & 94,0 \\
\hline \multirow{2}{*}{$\begin{array}{l}\text { - надання інших видів } \\
\text { послуг }\end{array}$} & 74490 & 76847 & 86709 & 89908 & 86147 & 100587 \\
\hline & & 103,2 & 112,8 & 103,7 & 95,8 & 116,8 \\
\hline
\end{tabular}


Таблиця 2. Показники структурної статистики по суб'єктах господарювання з розподілом за їх розмірами за період 2012-2017 рр.

\begin{tabular}{|c|c|c|c|c|c|c|c|c|}
\hline \multirow[b]{3}{*}{ Роки } & \multirow[b]{3}{*}{ Усього } & \multicolumn{7}{|c|}{ У тому числі } \\
\hline & & \multicolumn{4}{|c|}{ Підприємства } & \multicolumn{3}{|c|}{ Фізичні особи-підприємці } \\
\hline & & Усього & Великі & Середні & Малі & Усього & $\begin{array}{c}\text { Суб’єкти } \\
\text { середнього } \\
\text { підприєм- } \\
\text { ництва } \\
\end{array}$ & $\begin{array}{c}\text { Суб'єкти } \\
\text { малого } \\
\text { підприєм- } \\
\text { ництва } \\
\end{array}$ \\
\hline \multicolumn{9}{|c|}{ Кількість суб'єктів господарювання, одиниць } \\
\hline 2012 & 1600127 & 364935 & 698 & 20189 & 344048 & 1235192 & 361 & 1234831 \\
\hline 2013 & 1722070 & 393327 & 659 & 18859 & 373809 & 1328743 & 351 & 1328392 \\
\hline 2014 & 1932161 & 341001 & 497 & 15906 & 324598 & 1591160 & 712 & 1590448 \\
\hline 2015 & 1974318 & 343440 & 423 & 15203 & 327814 & 1630878 & 307 & 1630571 \\
\hline 2016 & 1865530 & 306369 & 383 & 14832 & 291154 & 1559161 & 281 & 1558880 \\
\hline 2017 & 1805059 & 338256 & 399 & 14937 & 322920 & 1466803 & 317 & 1466486 \\
\hline \multicolumn{9}{|c|}{ Кількість зайнятих працівників, тис. осіб } \\
\hline 2012 & 9957,6 & 7679,7 & 2484,2 & 3144,2 & 2051,3 & 2277,9 & 44,0 & 2233,9 \\
\hline 2013 & 9729,1 & 7406,5 & 2383,7 & 3012,1 & 2010,7 & 2322,6 & 42,1 & 2280,5 \\
\hline 2014 & 8796,7 & 6298,5 & 1915,1 & 2696,5 & 1686,9 & 2498,2 & 69,9 & 2428,3 \\
\hline 2015 & 8180,0 & 5889,7 & 1708,6 & 2604,7 & 1576,4 & 2290,3 & 28,0 & 2262,3 \\
\hline 2016 & 8108,3 & 5801,1 & 1586,6 & 2622,8 & 1591,7 & 2307,2 & 27,1 & 2280,1 \\
\hline 2017 & 8141,0 & 5812,9 & 1560,9 & 2593,1 & 1658,9 & 2328,1 & 30,7 & 2297,4 \\
\hline \multicolumn{9}{|c|}{ Обсяг реалізованої продукції, (товарів, послуг), млн грн } \\
\hline 2012 & 4459818,8 & 4203169,6 & 1761086,0 & 1769430,2 & 672653,4 & 256649,2 & 13015,4 & 243633,8 \\
\hline 2013 & 4334453,1 & 4050215,0 & 1717391,3 & 1662565,2 & 670258,5 & 284238,1 & 20778,9 & 263459,2 \\
\hline 2014 & 4459702,2 & 4170659,9 & 1742507,9 & 1723151,5 & 705000,5 & 289042,3 & 12742,7 & 276299,6 \\
\hline 2015 & 5556540,4 & 5159067,1 & 2053189,5 & 2168764,8 & 937112,8 & 397473,3 & 15612,0 & 381861,3 \\
\hline 2016 & 6726739,8 & 6237535,2 & 2391454,3 & 2668695,7 & 1177385,2 & 489204,6 & 14607,8 & 474596,8 \\
\hline 2017 & 8312271,9 & 7707935,2 & 2929516,6 & 3296417,9 & 1482001 & 604336,7 & 18538,2 & 585798,5 \\
\hline
\end{tabular}

Проаналізувавши наявні трактування, можна відзначити, що антикризове управління, суб'єктом господарювання яке є процесом, що полягає у використанні комплексу спеціальних методів та прийомів задля забезпечення сталих та економічно безпечних умов розвитку, передбачає:

- по-перше, пріоритетне попередження кризових явищ в ході функціонування підприємства;

- по-друге, зниження рівня проявів криз у разі їх реалізації в процесі господарювання суб'єкта ринку;

- по-третє, недопущення банкрутства підприємства та стабілізацію його становища у випадку настання глибокої кризи;

- по-четверте, запобігання повторення кризи на основі впровадження комплексу превентивних дій.

таблиця 3. Чистий прибуток (збиток) підприємств за видами економічної діяльності за період 2012-2017 pp.

\begin{tabular}{|c|c|c|c|c|c|c|}
\hline \multirow{2}{*}{ Вид економічної діяльності } & \multicolumn{6}{|c|}{ Роки } \\
\hline & 2012 & 2013 & 2014 & 2015 & 2016 & 2017 \\
\hline Загалом & 35067,3 & $-22839,7$ & $-590066,9$ & $-373516,0$ & 28583,4 & 168752,8 \\
\hline $\begin{array}{l}\text { - сільське, лісове та рибне } \\
\text { господарство }\end{array}$ & 26787,2 & 14984,5 & 21481,3 & 102849,1 & 90160,4 & 68858,5 \\
\hline - промисловість & 2592,4 & $-4181,1$ & $-178730,9$ & $-188267,9$ & $-29096,1$ & 56124,0 \\
\hline - будівництво & $-1012,7$ & $-5893,2$ & $-27948,8$ & $-25861,9$ & $-10179,6$ & $-5014,3$ \\
\hline - оптова та роздрібна торгівля & 210,6 & $-13248,5$ & $-133219,4$ & $-88161,0$ & $-4750,7$ & 25874,2 \\
\hline $\begin{array}{l}\text { - транспорт, складське } \\
\text { господарство, поштова та } \\
\text { кур'єрська діяльність }\end{array}$ & 3127,7 & $-1423,4$ & $-22591,6$ & $-17847,8$ & 7007,3 & $-16796,7$ \\
\hline $\begin{array}{l}\text { - тимчасове розміщування й } \\
\text { організація харчування }\end{array}$ & $-984,3$ & $-1416,7$ & $-6641,9$ & $-6874,9$ & $-1896,0$ & 1773,5 \\
\hline - інформація та телекомунікації & 3739,1 & 4881,5 & $-17137,1$ & $-12590,2$ & 1785,9 & 12029,3 \\
\hline $\begin{array}{l}\text { - фінансова та страхова } \\
\text { діяльність }\end{array}$ & 10769,4 & 5157,1 & $-5550,3$ & $-9573,5$ & $-788,6$ & 16806,6 \\
\hline - операції з нерухомим майном & $-9338,0$ & $-10192,2$ & $-105425,7$ & $-64369,0$ & $-41200,6$ & $-17551,2$ \\
\hline $\begin{array}{l}\text { - професійна, наукова та } \\
\text { технічна діяльність }\end{array}$ & $-1820,2$ & $-8390,3$ & $-100347,2$ & $-48656,0$ & 25036,8 & 32356,1 \\
\hline $\begin{array}{l}- \text { - діяльність у сфері } \\
\text { адміністративного та } \\
\text { допоміжного обслуговування }\end{array}$ & 3576,4 & $-1555,2$ & $-9543,2$ & $-9860,6$ & $-6528,7$ & $-3624,2$ \\
\hline - освіта & 112,8 & 119,0 & 62,5 & 80,7 & 85,6 & 96,1 \\
\hline $\begin{array}{l}\text { - охорона здоров'я та надання } \\
\text { соціальної допомоги }\end{array}$ & $-77,3$ & $-149,7$ & $-1185,3$ & $-1042,3$ & 33,5 & 145,0 \\
\hline $\begin{array}{l}\text { - мистецтво, спорт, розваги та } \\
\text { відпочинок }\end{array}$ & $-2547,6$ & $-1495,2$ & $-3244,0$ & $-3566,3$ & $-1301,3$ & $-2300,4$ \\
\hline - надання інших видів послуг & $-68,2$ & $-36,6$ & $-45,3$ & 225,6 & 215,5 & $-23,7$ \\
\hline
\end{tabular}

Відповідно до зазначеного, розглядаючи антикризове управління у часі, як і безпечний розвиток, його можна умовно поділити на два ключові етапи [5]. Перший етап у даному випадку полягає у стабілізації становища підприємства та виведення його 3 кризового стану.

У свою чергу, друга стадія передбачає забезпечення економічно безпечного становища задля створення передумови більш якісного та своєчасного реагування на прояви факторів загроз і попередження криз у майбутньому.

Але процес протидії та подолання криз не може носити хаотичний характер, він має бути ретельно структурованим, що дозволить оптимізувати наскільки це можливо використання ресурсів у певною мірою обмежені ресурси. За для цього суб'єктом антикризового управління розробляється антикризова стратегія, виробляється тактика, здійснюється співставлення потенціалу підприємства передбаченим заходам $[1 ; 4 ; 12 ; 16]$. Базисом у цьому випадку виступає дослідження умов функціонування та внутрішнього середовища підприємства, яке передбачає встановлення пріоритетів через брак ресурсів та часу на здійснення антикризового управління підприємством.

На основі зазначеного можна сформувати принципову модель механізму антикризового управління підприємством (рис. 6).

У цьому контексті на особливу увагу заслуговує питання антикризової тактики. На сьоГоднішній день 3 точки зору ситуативності прийняття рішень та комплексного характеру обмежень умов прийняття рішень виділяють дві найпоширеніші 3 них [1; 9; 12]: 
1. Захисна (заснована на заходах скорочення діяльності та, як правило, застосовується при значній несприятливості для підприємства зовнішнього оточення).

2. Наступальна (застосовується активний маркетинг, здійснюється завоювання часток на нових ринках збуту, здійснюється оновлення виробництва, впроваджуються перспективні технології, оновлюється номенклатура продукції тощо).

Вибір однієї із тактик має бути ретельно обгрунтованим, адже, від цього залежатиме здатність виходу підприємства 3 кризової ситуації, що істотною мірою визначатиметься професіоналізмом та кваліфікацією суб'єкта антикризового управління, що реалізовуватиме ключові функції.

Серед функцій антикризового управління, як і менеджменту загалом, зазвичай виокремлюють:

1. Планування (процес визначення цілей та їх змін, стратегій і програм антикризової стабілізації, ресурсів для їх досягнення).

2. Організація (формування оптимальної структури й обсягу використовуваних коштів, апарату управління і кадрів для ефективного використання основних ресурсів).

3. Мотивація (система заохочень і санкцій, що створює зацікавленість усього колективу і кожного працівника у зростанні ефективності діяльності підприємства 3 метою найшвидшого виходу з кризи).

4. Контроль (прогнозування відхилень від намічених цілей для своєчасного оперативного внесення змін, спрямованих на підвищення ефективності антикризових заходів).

Враховуючи існуючі підходи до виокремлення стратегій [16], ключових суб'єктів [8; 12] та сутності функцій менеджменту [1; 5; 9], представимо суб'єктово-функціональну схему антикризового управління підприємством (рис. 7).
Таблиця 4. Трактування визначення поняття "криза"

\begin{tabular}{|c|c|c|}
\hline Джерело & Визначення поняття & Джерело \\
\hline Сибіряков В. & $\begin{array}{l}\text { Будь-яка зміна якихось параметрів системи як позитивна, так і } \\
\text { негативна призводить до протилежної зміни інших параметрів } \\
\text { системи }\end{array}$ & [1] \\
\hline Крутько В. & $\begin{array}{l}\text { Раптовість, високий рівень загрози життево важливим інтересам і } \\
\text { гостра нестача часу для прийняття відповідних мір }\end{array}$ & {$[1]$} \\
\hline Дацюк I. & $\begin{array}{l}\text { Об'єктивний процес, що призводить до оптимізації системи або до їі } \\
\text { знищення у разі неспроможності адаптуватися до нових умов, адже } \\
\text { це ставлення грунтуєься на діалектичній єдності тенденцій в } \\
\text { існуванні системи: сталого функціонування та розвитку, що } \\
\text { поступово змінюють одна одну }\end{array}$ & {$[1]$} \\
\hline $\begin{array}{l}\text { Ткаченко А., } \\
\text { Єлець О. }\end{array}$ & $\begin{array}{l}\text { Широкомасштабна, непередбачена, переломна подія, яка призводить } \\
\text { як до негативних (що зумовлюють розбалансування системи } \\
\text { підприємства), так і позитивних наслідків у господарській } \\
\text { діяльності, які підвищують ефективність діяльності суб'єкта } \\
\text { господарювання, приводячи в дію трансформаційні сили, сприяючі } \\
\text { його еволюції }\end{array}$ & {$[7 ; 14]$} \\
\hline Грін П. & Втрата контролю над ситуацією & {$[2]$} \\
\hline Бартон Л. & $\begin{array}{l}\text { Широкомасштабна, непередбачена подія, яка веде до потенційно } \\
\text { негативних результатів, а також може завдавати серйозної шкоди } \\
\text { усій організації: працівникам, продукції, зв’язкам, фінансам та } \\
\text { репутації }\end{array}$ & [8] \\
\hline Галушко О. & $\begin{array}{l}\text { Об'єктивний процес, що призводить до оптимізації системи або до їі } \\
\text { знищення у разі неспроможності адаптуватися до нових умов та } \\
\text { розвиватися }\end{array}$ & [3] \\
\hline Чернявський О. & $\begin{array}{l}\text { Ситуативна характеристика функціонування будь-якого суб'єкта, що } \\
\epsilon \text { наслідком невизначеності в його зовнішньому та внутрішньому } \\
\text { середовищі }\end{array}$ & {$[15]$} \\
\hline Гренц Т. & $\begin{array}{l}\text { Незапланований та небажаний, обмежений в часі процес, який може } \\
\text { суттєво заважати і навіть зробити неможливим функціонування } \\
\text { підприємства }\end{array}$ & {$[1]$} \\
\hline $\begin{array}{l}\text { Розенталь Ю., } \\
\text { Піджненбург Б. }\end{array}$ & $\begin{array}{l}\text { Ситуація, позначена високою небезпекою, станом невпевненості, } \\
\text { відчуттям невідкладності тощо }\end{array}$ & [14] \\
\hline Крутик А. & $\begin{array}{l}\text { Будь-яка якісна зміна процесу, перехід від існуючого положення до } \\
\text { iншого, істотно відмінного за основними параметрами }\end{array}$ & {$[14]$} \\
\hline
\end{tabular}

Як бачимо, розробка та реалізація дієвого механізму антикризового управління має надати змогу підприємствам гнучко реагувати на загрозливі зміни в умовах функціонування, краще адаптовуватись, активно втручатися у хід ключових господарських процесів, сприяти зменшенню наслідків реалізації певних ризиків тощо. Усе це надасть можливість створити систему ефективного менеджменту, що забезпечить безперервний і планомірний процес сталого розвитку.

Ао перспектив подальших розробок у цьому напрямі має стати дослідження особливостей реалізації меха-

Таблиця 5. Визначення поняття "антикризове управління"

\begin{tabular}{|c|c|c|}
\hline Джерело & Визначення поняття & Джерело \\
\hline Грязнова А. & $\begin{array}{l}\text { Це така система управління підприємством, котра має комплексний, системний характер } \\
\text { та спрямована на передбачення або усунення несприятливих для бізнесу явищ за } \\
\text { допомогою використання всього потенціалу сучасного менеджменту }\end{array}$ & {$[11]$} \\
\hline Терещенко О. & $\begin{array}{l}\text { Це застосування специфічних методів та прийомів управління фінансами, які дають змогу } \\
\text { забезпечити безперервну діяльність підприємств на основі управління зовнішніми та } \\
\text { внутрішніми ризиками профілактики та нейтралізації фінансової кризи }\end{array}$ & {$[13]$} \\
\hline Коротков Е. & $\begin{array}{l}\text { Це управління, в якому поставлено певним чином передбачення небезпеки кризи, аналіз іiї } \\
\text { симптомів, заходів для зниження негативних наслідків кризи і використання іï факторів } \\
\text { для подальшого стійкого розвитку організації }\end{array}$ & [9] \\
\hline Василенко В. & $\begin{array}{l}\text { Це управління, в якому передбачена небезпека кризи, аналіз її симптомів, заходів щодо } \\
\text { зниження негативних наслідків кризи та використання її факторів для позитивного } \\
\text { розвитку }\end{array}$ & {$[1]$} \\
\hline Лігоненко Л. & $\begin{array}{l}\text { Це спеціальне, постійно організоване управління, націлене на найбільш оперативне } \\
\text { виявлення ознак кризового стану та створення відповідних передумов для його } \\
\text { своєчасного подолання з метою забезпечення відновлення життєздатності окремого } \\
\text { підприємства, недопущення виникнення ситуації його банкрутства }\end{array}$ & [9] \\
\hline Ситник Л. & $\begin{array}{l}\text { Це управління, що спрямоване на розв’язання задач інтенсивного розвитку підприємства } \\
\text { завдяки мобілізації та інтенсифікації всіх ресурсів на противагу екстенсивному розвитку }\end{array}$ & {$[12]$} \\
\hline $\begin{array}{l}\text { Мінаєв Е., } \\
\text { Панагушин В. }\end{array}$ & $\begin{array}{l}\text { Це не тільки управління, орієнтоване на виведення підприємства зі стану кризи, а й } \\
\text { управління, яке має заздалегідь спрогнозувати та запобігти неплатоспроможності } \\
\text { підприємства згідно з виробленою стратегічною програмою підвищення конкурентних } \\
\text { переваг та фінансового оздоровлення }\end{array}$ & {$[13]$} \\
\hline $\begin{array}{l}\text { Федотова М., } \\
\text { Маринюк А. }\end{array}$ & $\begin{array}{l}\text { Це управління підприємством, що має комплексний, системний характер та спрямоване } \\
\text { на запобігання або усунення несприятливих для бізнесу явищ за допомогою використання } \\
\text { всього потенціалу сучасного менеджменту, розроблення та реалізації на підприємстві } \\
\text { спеціальної програми, що має стратегічний характер і дає змогу усунути тимчасові } \\
\text { труднощі, зберегти та покращити ринкові позиції підприємства за будь-яких обставин, } \\
\text { використовуючи переважно власні ресурси }\end{array}$ & {$[7]$} \\
\hline
\end{tabular}




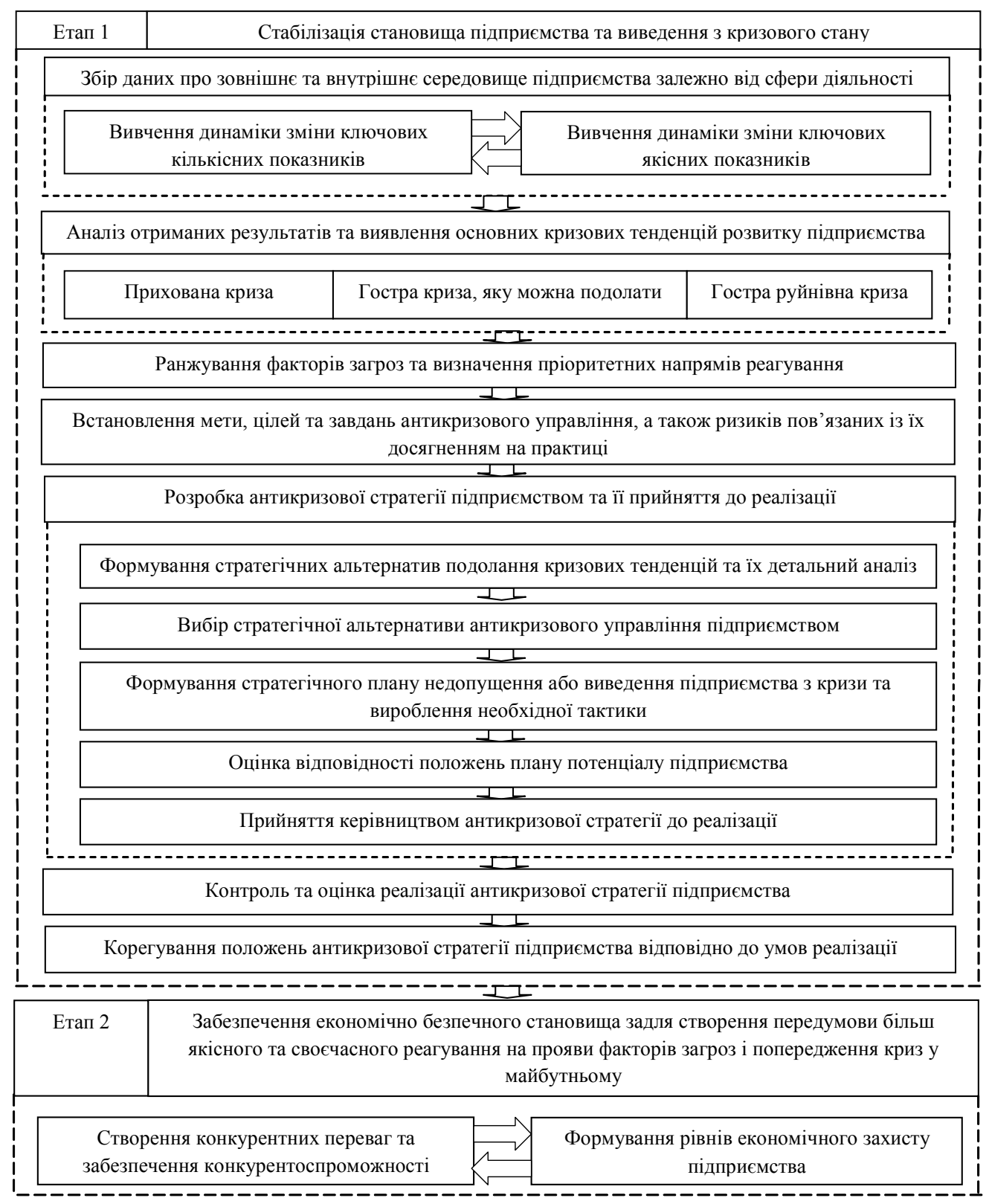

Рис. 6. Принципова модель механізму антикризового управління підприємством

нізму антикризового управління підприємствами у різних сферах вітчизняної економіки, а також пошук шляхів його удосконалення.

\section{$\Lambda$ ітература:}

1. Василенко В.О. Антикризове управління підприємством: навч. посібник / В.О. Василенко. - К.: ЦУ , 2003. -504 c.

2. Вишневская О.В. Механизмы антикризисного управления предприятием / О.В. Вишневская // Менеджмент в России и за рубежом. - 2007. - № 3. - С. $105-$ 113.

3. Галушко О.I.// Проблемы эффективного функционирования предприятий в современных условиях / O.I. Глушко // Материалы Всеукраинской научно-практич. конференции. - Севастополь: СевНТУ. - 2003.[Електронний ресурс]. - Режим доступу: http:// sevntu.com.ua/cgi-bin/irbis64r_72/cgiirbis_64.exe

4. Гринько Т. Стратегія як інструмент антикризового управління на підприємстві / Т. Гринько // Економіст. 2013. - № 8. - C. 51-53.

5. Аіденко Є.О. Особливості формування інноваційної безпеки підприємства / Є .О.Аіденко, Ю.С. Моторна// Електронне наукове фахове видання "Ефектив- на економіка". — Аніпропетровськ: АААЕУ, 2018. — № 1. - Режим доступу: http://www.economy.nayka.com.ua/ pdf/1_2018/46.pdf

6. Аіденко Є.О. Модель антикризового управління підприємством / Є.О. Аіденко // Вісник Київського національного університету технологій та дизайну. - 2015. - № 3 (87): Серія "Економічні науки". - С. 53-58.

7. Єлець О.П. Система антикризового управління підприємством: іï ознаки та принципи / О.П. Єлець // Вісник Хмельницького національного університету. Економічні науки. - 2007. - Т. 3. - № 6. - С. 316319.

8. Кривов'язюк I.B. Антикризове управління підприємством: навч. посібник / І. В. Кривов'язюк. - К.: Кондор, $2008-374$ с.

9. Аігоненко $\Lambda$. О. Антикризове управління підприє-

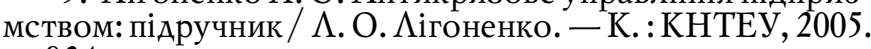
$-824 \mathrm{c}$.

10. Офіційний сайт Аержавної служби статистики України [Електронний ресурс]. - Режим доступу: http:/ /www.ukrstat.gov.ua

11. Рамазанов С.К. Технології антикризового управління / С.К. Рамазанов, О.П. Степаненко, А.А. Тимашова. - Куганськ: СНУ, 2004. - 191 с. 


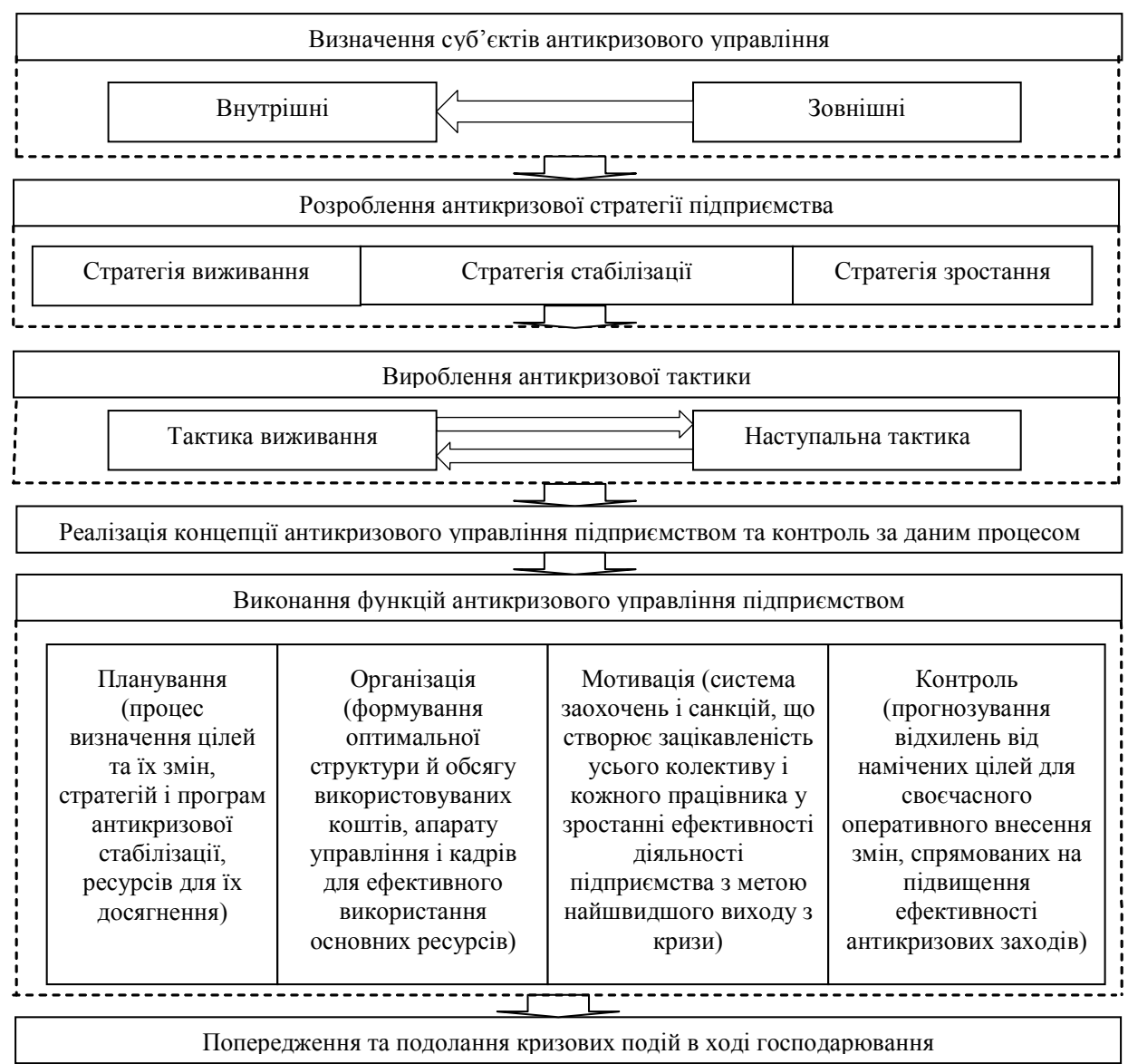

Рис. 7. Суб'єктово-функціональна схема антикризового управління підприємством

12. Скібіцький О.М. Антикризовий менеджмент: навч. посібник / О.М. Скібіцький. - К.: Центр учбової літератури, $2009-568$ с.

13. Терещенко О.О. Антикризове фінансове управління на підприємстві: навч. посіб. / О.О. Терещенко. K.: KHEУ, 2004. - 560 c.

14. Ткаченко А.М. Сучасний підхід до антикризового управління машинобудівним підприємством: монографія / А.М. Ткаченко, О.П. Єлець. - Запоріжжя: Видавництво Запорізької державної інженерної академії, 2010. $-277 \mathrm{c}$.

15. Чернявский А.А. Антикризисное управление: учеб. пособие/ А.А. Чернявський. - К.: МАУП, 2000. - 208 с.

16. Юрик Н.Є. Особенности выбора антикризисной стратегии на основе структурно-морфологического анализ / Н.Є. Юрик // Економічний часопис-XXI. 2011. - № 1-2. - C. 62-65.

\section{References:}

1. Vasylenko, V.O. (2003), Antykryzove upravlinnia pidpryiemstvom [Anticrisis management of the enterprise], TsUL, Kyiv, Ukraine.

2. Vishnevskaja, O. V. (2007), "Mechanisms of anti-crisis management of the enterprise", Menedzhment v Rossii i za rubezhom, vol. 3, pp. 105-113.

3. Galushko, O. I. (2003), "Problems of effective functioning of enterprises in modern conditions", Materialy Vseukrainskoj nauchno-praktich. Konferencii, [Online], available at: http://sevntu.com.ua/cgi-bin/irbis64r_72/ cgiirbis 64.exe (Accessed 1 Oct 2018).

4. Hryn'ko, T. (2013), "Strategy as an instrument of crisis management at the enterprise", Ekonomist, vol. 8, pp. 51-53.

5. Didenko, E. O. and Motorna, Yu. S. (2018), "Features of the formation of enterprise innovation security", Efektyvna ekonomika, [Online], vol. 1, available at: http:// www.economy.nayka.com.ua/pdf/1_2018/46.pdf (Accessed 1 Oct 2018).
6. Didenko, E. O. (2015), "Model of crisis management enterprise", Visnyk Kyivs'koho natsional'noho universytetu tekhnolohij ta dyzajnu, vol. 3 (87), pp. 53-58.

7. Yelets', O. P. (2007), "System of crisis management of the enterprise: its features and principles", Visnyk Khmel'nyts'koho natsional'noho universytetu. Ekonomichni nauky, vol. 6 (87), pp. $316-319$.

8. Kryvov'iaziuk, I. V. (2008), Antykryzove upravlinnia pidpryiemstvom [Anticrisis management of the enterprise], Kondor, Kyiv, Ukraine.

9. Lihonenko, L. O. (2005), Antykryzove upravlinnia pidpryiemstvom [Anticrisis management of the enterprise], KNTEU, Kyiv, Ukraine.

10. Official site of the State Statistics Service of Ukraine (2018), available at: http://www.ukrstat.gov.ua (Accessed 1 Oct 2018).

11. Ramazanov, S. K. Stepanenko, O. P. and Tymashova, L. A. (2004), Tekhnolohii antykryzovoho upravlinnia [Anticrisis management technologies], SNU, Luhans'k, Ukraine

12. Skibits'kyj, O. M. (2009), Antykryzovyj menedzhment [Anticrisis management], Tsentr uchbovoi literatury, Kyiv, Ukraine.

13. Tereschenko, O. O. (2010), Antykryzove finansove upravlinnia na pidpryiemstvi [Anticrisis financial management at the enterprise], KNTEU, Kyiv, Ukraine.

14. Tkachenko, A. M. and Yelets', O. P. (2010), Suchasnyj pidkhid do antykryzovoho upravlinnia mashynobudivnym pidpryiemstvom [Modern approach to crisis management machine-building enterprise], Vydavnytstvo Zaporiz'koi derzhavnoi inzhenernoi akademii, Zaporizhzhia, Ukraine.

15. Cherniavskyj, A. D. (2000), Antykryzove upravlinnia [Anticrisis management], MAUP, Kyiv, Ukraine.

16. Yuryk, N. Ye. (2011), "Features of the choice of anticrisis strategy based on structural and morphological analysis", Ekonomichnyj chasopys-XXI, vol. 1-2, pp. 62-65. Статта надійила до редакиії 04.11.2018 p. 
К.В.Гребеник, аспірант кафедри фінансів, Київсьий начіональний торговельно-економічний університет, м. Київ

\title{
РОЗВИТОК СИСТЕМИ БЮАЖЕТНОГО РЕГУАЮВАННЯ ЕКОНОМІКИ
}

\author{
K. Hrebenyk, \\ postgraduate student, Kyiv National University of Trade and Economics, Kyiv
}

DEVELOPMENT OF THE BUDGETARY REGULATION OF THE ECONOMY

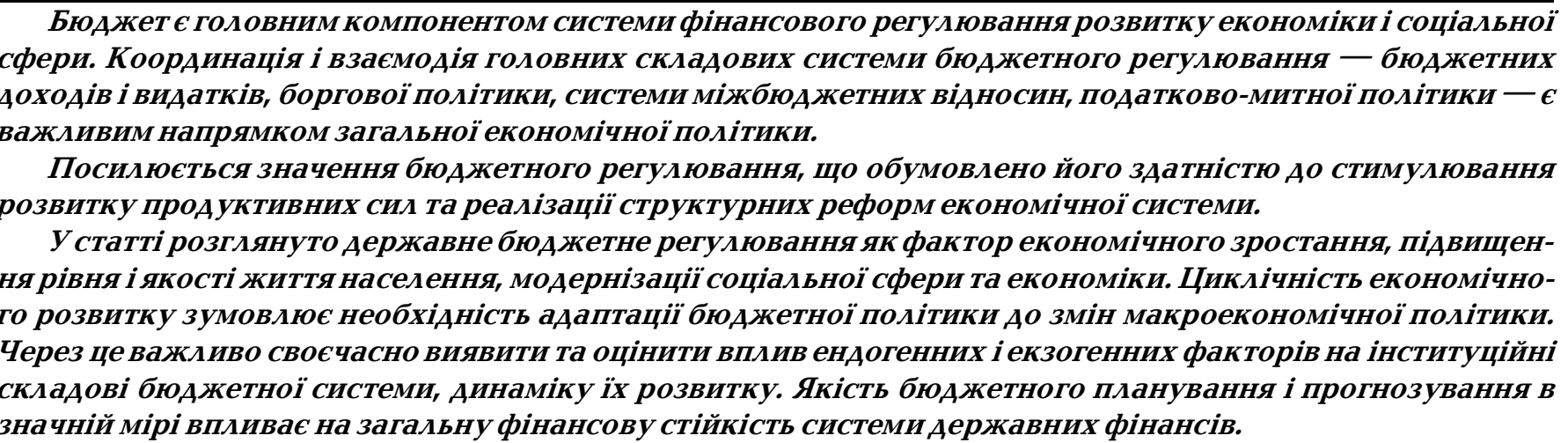

Бюджетне регулювання визначає обсяги первинного розподіАу ВВП, здійснює вПлив на Структуру зающаджень та динаміку боргових зобов'язань, забезпечує вирішення основних завдань суспільного розвитку та виступає інструментом реалізації внутрішнього потенціалу економічного зростання.

У роботі доведено важАивість науково-обгрунтованого визначення показників із урахуванням прогнозних тенденцій основних макроекономічних індикаторів національної економіки Аля Створення передумов Аля забезпечення сталого економічного розвитку У довгостроковій перспективі. Бюджетне регулювання соціального-економічного розвитку на базі,довгострокових Планів і прогнозів бюджету надає змогу: обгрунтовувати структурудоходів бюджету та визначати чіткі пріоритети У сфері видатків; Удосконалювати розподіл фінансових ресурсів дАя досягнення стратегічних цілей економічного розвитку; підвищувати відповідальність учасників бюджетного процесу; проводити ефективний фінансовий контроль убюджетному процесі.

The budget is a major component of the financial regulation system for economic and social development. Coordination and interaction of the main components of the system of budgetary regulation - budget revenues and expenditures, debt policy, intergovernmental fiscal relations, tax and customs policies - are an important area of overall economic policy.

The importance of budgetary regulation is increasing due to its ability to stimulate the development of productive forces and the implementation of structural reforms in the economic system.

The article considers state budget regulation as a factor of economic growth, raising the level and quality of life of the population, modernizing the social sphere and economy. The cyclical nature of economic development necessitates the adaptation of fiscal policy to changes in macroeconomic policy. Because of this, it is important to timely identify and assess the impact of endogenous and exogenous factors on the institutional components of the budget system and the dynamics of their development. The quality of budget planning and forecasting greatly affects the overall financial sustainability of the public finance system.

Budgetary regulation determines the volume of primary distribution of GDP, influences the structure of savings and the dynamics of debt obligations, provides for the solution of the main tasks of social development and acts as an instrument for realizing the internal potential of economic growth. 
The importance of the scientifically-based determination of indicators with the account of the forecast trends of the main macroeconomic indicators of the national economy for the creation of prerequisites for ensuring sustainable economic development in the long-term perspective is proved in the paper. Budgetary regulation of social and economic development on the basis of long-term plans and forecasts of the budget provides: to justify the structure of budget revenues and to determine clear priorities in the field of expenditures; improve the distribution of financial resources to achieve strategic goals of economic development; increase the responsibility of the participants in the budget process; to carry out effective financial control in the budget process.

Ключові слова: бюджет, бюджетна система, державні рінанси, бюджетне регулювання, економіка, доходи бюджету, видатки бюджету.

Key words: budget, budget system, state of finance, budgetary regulation, economy, budget revenues, budget expenditures.

\section{ПОСТАНОВКА ПРОБЛЕМИ}

В умовах ринкової економіки бюджет виступає головним компонентом системи фінансового регулювання економічного зростання. Результативність бюджетного регулювання залежить від рівня наукової обгрунтованості ролі бюджету в розвитку суспільних відносин, моделі соціально-економічного розвитку держави. Бюджет як фінансовий план держави і органів місцевого самоврядування виступає головним інструментом реалізації бюджетно-податкової політики держави в межах всієї країни в умовах інституційних перетворень.

Бюджетна політика є дієвим інструментом впливу держави на забезпечення якісного рівня соціально-економічного розвитку країни. Важливим є забезпечення координації та взаємодії головних складових системи бюджетного регулювання - доходів і видатків бюджету, боргової політики, системи міжбюджетних відносин, податково-митної політики, внутрішніх і зовнішніх факторів економічного середовища та ін. Посилення ролі бюджетного регулювання обумовлено його здатністю до стимулювання розвитку продуктивних сил та реалізації структурних реформ економічної системи.

Бюджетне регулювання економіки має бути спрямоване на реалізацію економічних перетворень, створення належних умов для підвищення ефективності та конкурентоспроможності фінансової системи, стимулювання економічного розвитку і покращення інвестиційного середовища.

\section{АНАЛІЗ ОСТАННІХ ДОСЛІДЖЕНЬ І ПУБЛІКАЦІЙ}

Система бюджетного регулювання економіки $є$ важливим питанням в економічній теорії. Питання бюджетування та податкового регулювання отримали наукове обгрунтування в працях В. Петті, А. Смітта, А. Рікардо та їх співвітчизників. Надалі питання фінансово-бюджетного регулювання були розглянуті у працях А. Маршала та Аж. Кейнса. Також вагомими дослідженнями теоретико-методологічних засад формування бюджетної політики є праці П. Кругмана, П. Самуельсона, Аж. Стігліца, В. Танзі та ін.

Розвиток системи бюджетного регулювання досліджували у своїх працях вітчизняні науковці: $\Lambda$. $\Lambda$ исяк, I. \ютий, А. Мазаракі, А. Максюта, В. Федосов, І. Чугунов, С. Юрій та ін. Проте існує потреба у подальшому вивченні теоретичних та практичних засад розвитку системи бюджетного регулювання як рушія економічних перетворень.

\section{ПОСТАНОВКА ЗАВДАННЯ}

Метою дослідження є теоретичне обгрунтування ролі бюджету в структурі державного регулювання еко- номічного розвитку, дослідження сучасних тенденцій розвитку системи бюджетного регулювання економіки, аналіз причинно-наслідкового зв'язку в бюджетному регулюванні.

\section{ВИКЛАД ОСНОВНОГО МАТЕРІАЛУ}

Аіяльність людей у процесі їх взаємодії, що спрямована на виробництво, обмін, розподіл і споживання товарів та послуг, сукупність заходів щодо регулювання економічної діяльності суспільства утворюють економічну систему. Бюджет як план доходів і видатків характеризує економічні відносини, що виникають під час акумулювання частини ВВП на користь держави з метою його подальшого перерозподілу відповідно до пріоритетів соціально-економічного розвитку. Бюджет формується на реалістичних показниках соціально-економічного розвитку держави, а також на прогнозних розрахунках надходжень і витрат бюджету. Бюджетна система як сукупність державного і місцевих бюджетів $€$ дієвим інструментом забезпечення макроекономічної стабілізації та стимулювання соціально-економічного розвитку. Економічне зростання є основним показником розвитку будь-якої країни. Бюджетна політика використовується як ефективний механізм впливу на макроекономічні процеси [5]. Аержавні фінанси виступають головним інструментом перерозподілу валового продукту країни та впливу на економічний розвиток країни. Бюджет є чітким вираженням економічної політики держави.

Економічна діяльність здійснюється в межах відповідної інституційної моделі, що представлена сукупністю взаємопов'язаних фінансових інститутів. I тому ефективна модель бюджетної політики будується на основі інституційного середовища суспільства - системи основних економічних, соціальних, політичних, правових положень, що, в свою чергу, визначаються історією, традиціями, культурою країні та ін. [5].

Метою бюджетного регулювання є створення відповідного суспільного середовища для стійкого економічного зростання та формування дієвих інституційних взаємовідносин щодо визначення пріоритетів проведення бюджетно-податкової політики, вдосконалення методологічних засад фінансово-бюджетного планування і прогнозування, розподілу та перерозподілу наявних фінансових ресурсів, ефективного фінансового контролю та використання бюджетних коштів, досягнення основних цілей соціально-економічного розвитку держави [6].

Бюджетне регулювання на сучасному етапі розвитку включає комплекс науково-обгрунтованих заходів держави щодо зміцнення і збільшення дохідної части- 
ни державного бюджету, посилення соціальної спрямованості бюджетних видатків, забезпечення макроекономічної стабілізації. Система бюджетного регулювання включає такі складові: податкова політика, доходи і видатки бюджету, дефіцит (профіцит) бюджету, державний борг, міжбюджетна політика, стан економічного розвитку у поточному періоді, загальна соціально-економічна політика уряду. На кожній стадії бюджетного процесу усі його учасники - під час складання, виконання, звітування про виконання бюджету - намагаються максимально досягнути запланованих цілей, залучаючи при цьому мінімальний обсяг бюджетних коштів при досягненні максимального фінансового результату.

Важливу роль у соціально-економічному розвитку країни займають доходи бюджету. Акумулювання фінансових ресурсів у державному та місцевих бюджетах забезпечує проведення злагодженої єдиної фінансової політики в соціально-економічній системі держави.

Загалом бюджетна політика включає в себе інституційні складові бюджетного середовища, цілі, заходи і завдання бюджетного регулювання щодо стимулювання економічно-соціального розвитку країни. Інституційний підхід передбачає розгляд бюджетного регулювання як динамічної системи, що постійно розвивається, вдосконалюється та адаптується до основних завдань соціально-економічного розвитку [5].

Стан фінансової системи України в значній мірі залежить від тенденцій розвитку світової економічної системи, через це останніми роками бюджетна система України орієнтована на іноземну фінансову допомогу [2]. Формування бюджету будується на рекомендаціях міжнародних фінансових інституцій; як наслідок - виникає недофінансування статей видатків, що могли б стимулювати економічний розвиток держави. Крім того, має місце скорочення бюджетних зобов'язань по соціальним статтям видатків бюджету - охорона здоров'я, освіта, культура, наука, соціальний захист [2].

Аосліджуючи стан системи державних фінансів та іiі вплив на загальний соціально-економічний розвиток, науковці визначали, що кредитні програми від міжнародних фінансових інституцій не стимулюють розвиток національної економіки. Кошти, що залучаються від кредиторів, не використовуються на проведення нової індустріалізації та модернізації сфери суспільних послуг. Також економісти за основу дослідження брали постулати, що саме внутрішня фінансова система країни $є$ потужним фактором соціально-економічного зростання.

Американські науковці дотримуються думки, що кожна держава повинна розвивати свою економіку незалежно від Міжнародного Валютного Фонду та Світового банку, розвивати і підтримувати власне виробництво, забезпечувати сталий розвиток бюджетно-податкової системи. Тільки за таких умов фінансова система буде збалансованою.

У значній мірі результативність бюджетного регулювання залежить від рівня наукової обгрунтованості його ролі в розвитку суспільних відносин, моделі соціально-економічного розвитку держави тощо [5].

При розробці заходів бюджетного регулювання бюджетна стратегія визначається з урахуванням циклічності економічного розвитку, стану системи державних фінансів і запасу фінансової стійкості бюджетної системи.

У структурі доходів державного бюджету найбільшу частку займають податкові надходження. Питома вага податкових надходжень державного бюджету до ВВП за період 2010 - 2017 фінансові роки коливається в межах 16,6\% - 21,0\% ВВП. Така тенденція свідчить про зростання ролі податкової політики у системі бю-
Ажетного регулювання. Вітчизняна статистика свідчить, що низький рівень податкового навантаження на економіку призводить до виникнення дисбалансів в економічній системі, зокрема - недофінансування бюджетних програм, програм соціального і економічного розвитку, збільшення розвитку між доходами і видатками тощо. Проте такі країни, як Німеччина, Франція, Швейцарія, Японія, Китай, Індія та ін. знижують рівень податкового навантаження на підприємства і населення 3 метою економічного стимулювання.

Бюджет є головною складовою ринкової економіки. Актуальним є вивчення досвіду побудови і реалізації фінансової політики розвинутих країн, а також можливостей його застосування у вітчизняній економічній системі. Наприклад, значна кількість розвинутих країн світу в напрямку податкового регулювання використовує, в першу чергу, механізми прямого податкового регулювання, а вже потім - непрямого. В цих країнах увага зосереджена на прибутковому оподаткуванні, яке $є$ соціально справедливим.

Актуальними напрямами реалізації бюджетної політики є забезпечення збалансованості економічного розвитку; зниження рівня інфляції та утримання цього показника на сталому рівні; забезпечення структурної перебудови економіки; застосування податкових інструментів щодо стимулювання розвитку вітчизняних товаровиробників, збільшення обсягу валового внутрішнього продукту, зменшення податкового навантаження на вітчизняних економічних суб'єктів; проведення ефективних структурних реформ в напрямку соціально-економічного зростання; продовження процесу бюджетної децентралізації і забезпечення самостійності місцевих бюджетів; оптимізація рівня бюджетного дефіциту і державного боргу та ін.

Бюджет є головним фінансовим інструментом впливу на економіку. У бюджеті зосереджується значна частина фінансових ресурсів, що спрямовуються на фінансування пріоритетних напрямів економічного розвитку, реалізацію єдиної соціально-економічної політики. Стійкість і збалансованість бюджетної системи досягається за рахунок дотримання основних прогнозних індикаторів соціально-економічної політики. Повноваження на здійснення витрат бюджету мають в повному обсязі відповідати обсягу надходжень до бюджету відповідного рівня на відповідний бюджетний період.

У бюджетній політиці важливе місце займають довгострокові завдання бюджетного регулювання стимулювання економічного зростання; підвищення соціального забезпечення населення країни; підвищення ефективності використання фінансового потенціалу країни в цілому та її адміністративно-територіальних одиниць. Бюджет 2018 р. розрахований на базі Основних напрямів бюджетної політики на 2018-2020 рр. у рамках переходу до середньострокового бюджетного планування відповідно до Стратегії реформування системи управління фінансами на 2017-2020 роки. Так, одним 3 головних інструментів державного регулювання соціально-економічного зростання є перспективне бюджетне планування, призначення якого реалізується у розробці основних напрямів формування і використання коштів бюджету на середньо- та довгостроковий період відповідно до державної політики.

Видатки бюджету за своєю економічною природою $€$ інструментом досягнення вищого критерію справедливості та корисності для кожного члена суспільства. У видатках бюджету чітко прослідковується фінансова політика держави щодо державного регулювання і стимулювання виробництва, фінансового забезпечення соціального захисту населення, розвитку науково-технічного прогресу, міжнародної діяльності. Раціональна структура видатків бюджету забезпечує надійне функціонування держави та сприяє економічному зростанню. 
Одним з основних завдань бюджетного регулювання є упорядкування кількості бюджетних програм, складання головними розпорядниками бюджетних коштів плану діяльності на наступні бюджетні періоди відповідно до пріоритетів соціально-економічного розвитку [5].

Формування оптимального складу і структури видатків є пріоритетним напрямком дослідження і розвитку, оскільки саме видатки є ресурсною базою органів влади у проведенні бюджетної політики, реалізації соціальних та економічних реформ, що за загальну мету мають зміцнення фінансової системи країни.

Актуальним є вдосконалення системи державного управління в напрямку підвищення результативності використання бюджетних видатків щодо обгрунтування пріоритетів при розподілі коштів бюджету; застосування принципів перспективного бюджетного планування і прогнозування; оптимізації бюджетних програм 3 урахуванням загальнодержавних пріоритетів та удосконалення методології оцінки їх результативності; підвищення ефективності і результативності контролю за цільовим використанням фінансових ресурсів; вдосконалення моніторингу діяльності розпорядників бюджетних коштів тощо.

Аосвід передових країн світу свідчить, що підтримка галузей економіки, в першу чергу сільського господарства та будівництва, через пряме фінансування $€$ ефективним інструментом стимулювання їх розвитку. Такі заходи, як надання цільових дотацій із бюджету, компенсація процентних ставок за кредитами, механізми державно-приватного партнерства дозволяють підтримувати і забезпечувати стабільний і стійкий розвиток всієї економіки.

Важливе значення в умовах фінансової глобалізації приділяється якості та обсягу людського капіталу. У європейських країнах держава фінансує значну частину витрат на відтворення людського капіталу, здійснює вплив на підвищення якості людського капіталу, збільшення висококваліфікованих кадрів та на використання їх потенціалу, стимулюючи при цьому попит на наукові знання та примножуючи можливості країни у забезпеченні економічного зростання.

Видатки бюджету на інвестування та інноваційний розвиток у довгостроковій перспективні забезпечують реалізацію цілей економічного і соціального розвитку країни. Аля стимулювання розвитку інноваційної складової економіки, уряди країн у свою фінансову політику закладають надання державних гарантій під високотехнологічні інвестиційні проекти. Наприклад, економіка Китаю побудована на інноваційній моделі; наука в країні виступає каталізатором розвитку фінансової системи, підтримується державою на загальнодержавному рівні і у довгостроковій перспективі; фінансується одразу на трьох рівнях: державному, регіональному і муніципальному. Загалом, бюджетні видатки активно сприяють економічному зростанню за рахунок пріоритетного фінансування наукових досліджень, підтримки найважливіших галузей економіки, вирівнювання регіональних диспропорцій.

Бюджетним видаткам притаманна соціальна спрямованість у напрямі задоволення суспільних потреб у сфері охорони здоров'я, підтримки малозабезпечених верств населення, забезпечення соціального захисту і соціального забезпечення громадян, через це має місце необхідність удосконалення соціальної політики держави як складової загальної фінансової. Соціальна функція держави реалізовується у програмах соціального розвитку та спрямовується на забезпечення реалізації основних завдань соціально-економічного розвитку країни, стабілізацію та розвиток соціальних відносин у суспільстві. Фінансування суспільних потреб грунтується на основі оптимізації видатків бюджету з урахуванням критеріїв підвищення показників ефективності функціонування організацій соціального забезпечення і дотримання принципу цільового надання соціальної допомоги.

Перевищення видатків над доходами бюджету зумовлює появу бюджетного дефіциту. Оптимальним критерієм для дефіциту бюджету згідно з Маастрихтським договором визнано 3\% ВВП. За період 2010 - 2017 рр. показник зведеного бюджету до ВВП знаходиться в межах 6,0\% ВВП (2010 р.) - 1,4\% ВВП (2017 р.). На 2019 р. урядом закладається граничний обсяг дефіциту державного бюджету на рівні 2,2\% ВВП, а обсяг самого валового внутрішнього продукту на рівні 3 733,9 млрд грн.

Бюджетному дефіциту притаманна регулююча функція - під час спаду виробництва допускається перевищення видатків над доходами, в період економічного піднесення доходи перевищують видатки. Розмір бюджету (особливо його дефіциту), методи і напрями податкової політики, структура видатків бюджету визначають темпи економічного зростання, процентні ставки, рівень зайнятості населення, цінову політику та інші макроекономічні показники, що відображують стан розвитку економіки держави.

Питання збалансування бюджетної системи вирішуються за рахунок обгрунтованого вибору джерел його покриття - додаткова емісія готівкових грошей, продаж державних цінних паперів, державні позики, збільшення податкового навантаження на економічних суб'єктів. Світова практика свідчить, що ресурси, за рахунок яких покривається дефіцит, необхідно спрямовувати на інвестування в реальний сектор економіки, що забезпечує соціально-економічне зростання на довгостроковій перспективі. Рівень інвестицій із державного бюджету має перевищувати або бути рівним бюджетному дефіциту.

Основною метою бюджетної системи є підвищення рівня та якості життя населення, що забезпечується через досягнення високих темпів економічного та фінансового зростання за рахунок створення нових робочих місць, підвищення доходів громадян та розширення фінансових можливостей країни [2]. Аосягається зазначене в першу чергу через макроекономічну стабільність та розвиток реального сектору економіки.

При формуванні засад бюджетного регулювання щодо забезпечення економічного зростання та сталого розвитку соціальної сфери уряд враховує сучасні пріоритетні сфери використання бюджетних коштів, напрями бюджетно-податкової політики у середньостроковій перспективі. Бюджетна політика економічного зростання враховує збалансованість державного бюджету у середньостроковій перспективі, послідовність бюджетної політики та передбачуваність розподілу обмеженого фінансового ресурсу. Сучасна бюджетна політика спрямована на збалансований розвиток економічної системи, забезпечення збалансованої структури державного бюджету, розвиток міжбюджетної політики, забезпечення якісного механізму обслуговування державного дефіциту і державного боргу.

Головними стратегічними завданнями бюджетного регулювання економічного зростання є: подальше використання перспективного бюджетного планування і прогнозування на державному і місцевих рівнях; посилення обгрунтованості і ефективності використання коштів бюджету; забезпечення збалансованості та реальності бюджету; підвищення прозорості та ефективності міжбюджетної політики; реалізація бюджетної політики відповідно до вимог вітчизняного та європейського законодавства, зокрема чітке дотримання принципів бюджетної системи; забезпечення ефективного і дієвого фінансового контролю на кожному етапі бюджетного процесу.

Фінансова політика країни на даний час побудована на основі довгострокового програмно-цільового бюджетування і спрямована на зменшення суми дотацій до бюджетів рецесивних територій, а також на розвиток 
фінансової політики в напрямі децентралізації бюджетних відносин. Міжбюджетна політика щодо розподілу видів видатків між державним і місцевими бюджетами, та між місцевими бюджетами здійснюється відповідно до норм вітчизняного законодавства та грунтується на принципі "субсидіарності" - максимально можливому наближенні надання суспільних послуг до їх безпосереднього споживача.

Проведення структурних змін в економічному середовищі передбачає застосування збалансованого підходу до функціонування бюджетної системи [6].

За свою економічною сутністю видатки є інструментом досягнення вищого критерію справедливості і корисності для кожного члена суспільства. У видатках бюджету чітко прослідковується роль держави у регулюванні макроекономічних процесів, економічному зростанні та належному соціальному забезпеченні суспільства тощо. Головне призначення видатків - фінансове забезпечення реалізації функцій держави щодо задоволення потреб суспільства у економічному та соціальному розвитку, державного управління, оборони, забезпечення громадського порядку, безпеки держави тощо. Аержава використовує видатки як дієвий інструмент впливу на соціально-економічний розвиток держави. Економічна ефективність видатків у системі економічного розвитку виражена у сукупності досягнутих результативних показників, які відповідають головним цілям та пріоритетним завданням бюджетних призначень 3 урахуванням обсягу здійснених видатків, дієвості інституційних перетворень розвитку суспільства.

Від якості бюджетного планування і прогнозування залежить фінансова стійкість системи державних фінансів.

Підвищення ефективності бюджетних видатків забезпечується через узгодження цілей бюджетних програм та пріоритетів соціально-економічного розвитку держави та адміністративно-територіальних одиниць.

Бюджетне регулювання визначає обсяги первинного розподілу ВВП, здійснює вплив на структуру заощаджень та динаміку боргових зобов'язань, забезпечує вирішення основних завдань суспільного розвитку та $€$ фінансовим інструментом реалізації внутрішнього потенціалу економічного зростання [6].

Важливим $є$ забезпечення передбачуваності бюджетно-податкової політики у середньостроковій перспективі, а також адаптація фінансової політики до тенденцій циклічного розвитку економіки за рахунок: формування сучасних фінансових інститутів, збалансування фіскального навантаження, досягнення індикативних граничних значень державного боргу да дефіциту бюджету тощо. Формування бюджетної політики здійснюється з урахуванням принципів стабільності, передбачуваності податкової політики, ефективного управління державним зовнішнім і внутрішнім боргом, обгрунтованого прогнозування основних фінансово-економічних і соціальних показників тощо.

Перспективне бюджетне планування і прогнозування [5] як один з основних інструментів державного регулювання соціально-економічного розвитку включає в себе розробку основних напрямів формування і використання коштів бюджету на середньо- та довгостроковий період, враховуючи при цьому необхідність виконання завдань, що виникають перед суспільством на певному етапі його розвитку.

Аовгострокове бюджетне планування і прогнозування лежить в основі збалансованості бюджетної системи. Планування бюджету на довгостроковій основі гарантує стійкий розвиток бюджетної системи; дозволяє оцінити їі потенціал та виокремити пріоритетні завдання економічного розвитку; визначити галузі господарства, що потребують збільшення фінансування для іх підтримки і розвитку; дослідити статті доходів та витрат, їх вплив на фінансову стійкість держави; ефективність національного виробництва [2].

\section{ВИСНОВКИ ІПЕРСПЕКТИВИ ПОДАЛЬШИХ ДОСЛІДЖЕНЬ}

Бюджетне регулювання є одним із дієвих інструментів забезпечення макроекономічної стабілізації та активізації соціально-економічного зростання. Економічне призначення бюджету реалізується у забезпеченні формування конкурентного ринкового середовища, стимулюванні структурної перебудови економіки, фінансовій підтримці перспективних і важливих галузей національного виробництва, стимулюванні розвитку вітчизняних товаровиробників та сприянні експорту вітчизняної продукції на світові ринки, формуванні і реалізації боргової політики тощо. Бюджетна політика фінансового регулювання є одним із дієвих інструментів забезпечення макроекономічної стабілізації та подальшої активізації економічного зростання.

Сутність бюджетного регулювання економіки полягає у взаємодії інституційних та економічних компонентів бюджетної системи, а також складових фінансової архітектоніки, що забезпечує розробку і реалізацію напрямів бюджетної політики щодо досягнення тактичних і стратегічних цілей соціально-економічного розвитку країни [6].

Позитивний вплив на макроекономічну збалансованість бюджетної системи країни здійснює довгострокове бюджетне планування, оскільки в значній мірі стримує необгрунтоване підвищення витрат бюджету. Бюджетна стратегія забезпечує довгостроковий соціальноекономічний розвиток держави та їі адміністративнотериторіальних одиниць. Бюджетне регулювання фінансової системи відповідає довгостроковим цілям розвитку економічної системи та забезпечення досягнення соціальних норм.

\section{$\Lambda$ ітература:}

1. Боголіб Т.М. Бюджетна система України: нова реальність та глобальні виклики // Економічний часопис. - XXI. - 2016. - № $1-2$. - C. 41-43.

2. Аержавне фінансове регулювання економічних перетворень: монографія / I.Я. Чугунов, А.В. Павелко, Т.В. Канєва, та ін.; за заг. ред. А.А. Мазаракі. - К.: Київ. нац. торг.-екон. ун-т, 2015. - 376 с.

3. Ерроу К.Аж. Нарис з історії поведінки в умовах ринку. - К., 2014. - 372 с.

4. Чугунов I.Я. Бюджетні відносини в системі соціально-економічного розвитку країни // Казна Україна. - 2014. - № 6. - C. $25-28$.

5. Чугунов I.Я., Ігнатюк I.M. Формування видатків бюджету у системі соціально-економічного розвитку країни // Економічний вісник університету. ПереяславХмельницький державний університет імені Григорія Сковороди. - 2016. - № 28/1. - С. 217-226.

\section{References:}

1. Boholib, T. M. (2016), "The Budget System of Ukraine: New Reality and Global Challenges", Ekonomichnyj chasopys - XXI, vol. $1-2$, pp. $41-43$.

2. Chugunov, I.Ya. Pavelko, A.V. and Kanieva, T.V. (2015), Derzhavne finansove rehuliuvannia ekonomichnykh peretvoren' [State Financial Regulation of Economic Transformations], Kyiv. nats. torh.-ekon. un-t, Kyiv, Ukraine.

3. Arrow, K. J. (2014), Narys z istorii povedinky v umovakh rynku [An Essay on the History of Behavior in Market Conditions], Kyiv, Ukraine.

4. Chugunov, I. Ya, (2014), "Budget relations in the system of socio-economic development of the country", Kazna Ukraine, vol. 6, pp. 25-28.

5. Chugunov, I. Ya. and Ihnatiuk, I. M. (2016), "Formation of budget expenditures in the system of socio-economic development of the country", Ekonomichnyj visnyk universytetu. Pereiaslav-Khmel'nyts'kyj derzhavnyj universytet imeni Hryhoriia Skovorody, vol. 28 \1, pp. 217226.

Стаття надійшла до редакиї 22.10.2018 p. 


\title{
ЕКОНОМІЧНА НАУКА
}

\section{УАK 332.6}

К.В.Загребельна, аспірант кафедри начіональної економіки та публічного управління, Киїьський начіональний економічний університет імені Вадима Гетьмана, м. Киїъ

\section{АИНАМІКА КОН'ЮНКТУРИ РИНКУ HEPУХOMOCTI В УКРАЇ̈I}

\author{
K. Zahrebelna, \\ postgraduate student at the Department of National Economy and Public Administration, \\ SHEE "Kyiv National Economic University named after Vadym Hetman"
}

\section{THE DYNAMICS OF THE REAL ESTATE MARKET CONDITIONS IN UKRAINE}

У Статті виокремлено та здійснено макроекономічний аналіз кон'юнктури ринку нерухомості в Україні за останне десятиліття. Сформульовано головні чинники, які будуть обумовлювати подальші персПективи його розвитку. Обгрунтовано взаємодію чинників, що визначають особливості динаміки співвідношення попиту та пропозиції на житло в Україні.

Проведено аналіз сучасного стану формування ринку нерухомості України, його основних сегментів: первинного і вторинного ринку житлової нерухомості. Аналіз кон'юнктури ринку нерухомості міста Києва показує, що під впливом несприятливої ринкової кон'юнктури пропозиції істотно перевищують попит. Після Підвищення реальних, дохдів основної маси покупців можна очікувати зростання цін, але він не може бути в істотних розмірах.

Проаналізовано фактори, які впливають на прийняття рішень і визначають якість середовища, що вПливають на суб'єкти ринку. На основі проведеного аналізу встановлено основні загрози, можливості, Сицьні та САабкі Сторони розвитку ринку нерухомості в Украӥни, які прямо чи опосередковано вПливають на інструменти фінансування та в цілому Стимулювання сфери діяльності. 3 точки означеного, доСлідження динаміки кон'юнктури ринку нерухомості в Україні є актуальною та має практичну значимість Аля обгрунтування політики забезпечення житлом громадян Украйни, які потребують допомоги з боку держави. Відповідно до вищезазначеного, слід виокремити низку можАивих перспективних напрямів удосконалення житлової політики держави з метою поліпшення становища уцій сфері.

The article represents the macroeconomic analysis of the real estate of the market conditions in Ukraine has been made for the last decade. The main factors that will determine the future prospects of its development are formulated. The interaction of factors that determine the peculiarities of the dynamics of the ratio of supply and demand for housing in Ukraine is substantiated.

An analysis of the current state of the Ukrainian real estate market is conducted. Its main segments: the primary and secondary residential real estate market. The analysis of the market situation of the Kiev real estate market shows that under the influence of unfavorable market conditions the supply substantially exceeds demand. After rising real incomes, most buyers may expect price increases, but this can't be substantial.

The factors that influence the decision making and determine the quality of the environment affecting the market actors are analyzed. Based on the analysis, the main threats were identified. Strengths and weaknesses of the real estate market in Ukraine. Which directly or indirectly affects the financing instruments and, in general, the stimulation of the field of activity.

The heads of the staff are formed, they will be charged with the perspectives of their development. From the point of view, the study of the dynamics of the real estate market situation in Ukraine is relevant and has practical significance to justify the policy of providing housing for Ukrainian citizens in need of state assistance. In line with the foregoing, a number of possible prospective directions of improvement of the housing policy of the state 
should be singled out in order to improve the situation in this area. According to the results of the study, we can conclude that the problem of providing the population of Ukraine with social housing has become very acute. The role of the state is precisely to in troduce the tools of the real estate market activation through the use of the financial mechanism.

Ключові слова: попит, пропозичія, ринок нерухомості, кон'юнктура, динаміка, первинний $і$ вторинний ринок житлової нерухомості.

Key words: supply, demand, the real estate market, market conditions, dynamics, primary and secondary market of the real estate.

\section{ПОСТАНОВКА ПРОБЛЕМИ}

Основною метою статті є виявлення чинників, що впливають 3 одного боку на структурні зміни платоспроможного попиту на різні види нерухомості, а 3 другого - на визначення сукупної пропозиції нерухомості в економіці України. Розглянуто умови, при яких забезпечується найбільша потреба населення в товарах даного виду і, відповідно, формуються передумови для ефективної реалізації такого специфічного товару, як нерухомість. Відправною теоретико-методологічною засадою нашого дослідження послужили теорії кон'юнктури ринку, які викладені в працях вчених В. Зомбарта (Німеччина), Г. Касселя (Швеція), В. Репке (Швейцарія), А. Афтальона (Франція), А. Пігу, А. Робертсона (Великобританія). Проблемам формування ринку нерухомості присвячено праці вітчизняних вчених, а саме: I. Геллера, О. Гриценка, В. Вороніна, А. Галагана, В. Йлкіна, А. Монченкова, Н. Олійник, $\Lambda$. Паламарчука та ін., в яких розглядаються питання категоріальної матриці визначення нерухомості як специфічного товару та кон'юнктура ринку. Відповідно до цього першочерговим завданням, на наш погляд, виявився аналіз тенденцій та змін поточного співвідношення попиту та пропозиції, тобто динаміки кон'юнктури ринку нерухомості в Україні. Такий підхід дозволяє виявити причинну коливання кон'юнктури, формуючи аналітичну базу для ухвалення адекватної та результативної політики регулювання національної економіки. Верифікація теоретичної спадщини з означеної тематики та проблеми цінової нестабільності на житло в часовому періоді в $\mathrm{У}_{\text {к- }}$ раїні дозволяють зробити висновок про актуальність дослідження динаміки кон'юнктури з точки зору впливу таких макроекономічних факторів як інфляція, зайнятість, платоспроможний попит, інвестиційний клімат, державна соціальна політика тощо. Теоретичні положення, що викладені в даній статті, можуть бути використані при розробці стратегії муніципального управління Києва та інших міст України.

\section{АНАЛІЗ ОСТАННІХ ДОСЛІДЖЕНЬ}

Нерухомість - це складова національного багатства держави, тобто сукупність матеріальних благ та об'єктів, накопичених в країні в результаті праці людей та інвестиційного використання заощаджень (житло, будівлі культурного та виробничого призначення тощо), а також частина природних ресурсів (земельні, водні, лісові та інші ресурси), які придатні для економічного і соціального використання. В ринкових умовах функціонування економічної системи означені матеріальні блага та ресурси набувають форми товару.

Призначенням ринку нерухомості є торгівля землею, виробничими і невиробничими об'єктами, що на ній збудовані, в тому числі житловими будинками, квартирами [1, с. 17]. Суб'єктами цього сектору ринку виступають фізичні та юридичні особи, які можуть купувати об'єкти нерухомості як для особистого (будинок, квартира), так і виробничого споживання (будівлі, приміщення для організації виробничого процесу, земельні ділянки для сільськогосподарської і несільськогосподарської діяльності, приміщення для офісів, комерційної діяльності та ін.).

Кон'юнктура ринку нерухомості являє собою форму прояву на інвестиційному ринку у цілому чи на окремих його сегментах системи факторів (умов), що визначають співвідношення попиту, пропозиції, цін і рівня конкуренції.
Аослідження кон'юнктури передбачає її системний аналіз, який повинен охоплювати уточнення термінології, виокремлення та розгляд впливу на динаміку попиту та пропозиції на ринку нерухомості факторів макроекономічного інституційного та мікроекономічного характеру.

3 точки зору сутності, кон'юнктура (від лат. conjunctura — пов'язувати, з'єднувати) - сукупність певних умов, збіг обставин, стан речей, здатний впливати на вирішення, розв'язання якої-небудь справи, питання тощо. Уперше термін "кон'юнктура" використав у літературі в середині XIX ст. Ф. Аассаль, який визначав її як "...ланцюг, який всі існуючі, невідомі обставини пов'язує між собою..." [2]. То була перша спроба економістів визначити й пояснити вплив різноманітних факторів на ринок та на підприємства, що функціонують на цьому ринку.

Важливі дослідження теорії кон'юнктури належать також до 60-х років XX ст. Слід відзначити вченого Ф.Г. Піскоппеля, який визначив поняття кон'юнктури як конкретний процес відтворення капіталістичного господарства, що розглядається в безпосередньому ринковому відображенні, у щоденних коливаннях та змінах, у всіх зв'язках та опосередкованостях [3]. За С. Мочерним: "Кон'юнктура - найважливіші ознаки, риси, показники, які характеризують поточний і перспективний стан ринку, відображає економічну ситуацію, яка складається на ньому, характеризується рівнями попиту, пропозиції, динаміки цін" [4].

Основна мета аналізу динаміки випливає із самого визначення кон'юнктури - виявлення та моделювання тенденцій та закономірностей розвитку ринку. Аля її досягнення необхідно послідовно вирішувати такі завдання:

— визначити об'єкт аналізу;

- зібрати та опрацювати інформацію про об'єкт дослідження і пов'язані з ним економічні процеси;

— оцінити особливості стану досліджуваного ринку, виявити поведінку суб'єктів, що діють на ринку;

- оцінити й проаналізувати потенціал та основні пропорції ринку;

— виявити основні тенденції розвитку ринку, його коливання, сезонність, циклічність.

Загалом етапи аналізу динаміки кон'юнктури можна поділити на два рівні реалізації. На першому етапі здійснюється аналіз ринкової кон'юнктури, що повинен охарактеризувати масштаби й типологію ринку, його головні пропорції, вектор і швидкість зміни основних параметрів, рівень стабільності розвитку. На другому етапі - здійснюється спроба побудувати модель ринкових взаємозв'язків і спрогнозувати ринкову ситуацію.

Учені трактували й розвивали вчення про кон'юнктуру в рамках теорії криз і циклічних коливань, і довгий час теорія була найголовнішою, тобто відбувалася заміна теорії криз теорією кон'юнктури. Швейцарський економіст В. Репке писав, що кон'юнктура $є$ співвідношення попиту та пропозиції на ринку, тобто співвідношення, яке неможливо визначити й яке схильне до постійних змін [5]. Важливо зазначити, що теоретичному обгрунтуванню економічної кон'юнктури присвячено праці М.I. Туган-Барановського, який запровадив загальне поняття економічної кон'юнктури, пояснив її суть та значимість для дослідження динаміки народного господарства в цілому. Послідовник теорії Тугана-Барановського М.А. Конаратьєв розробив вчення про вплив оборотних та необоротних коштів на коливання кон'юнктури, маючи на увазі, що "Під економічною кон'юнктурою кожного да- 
Таблиця 1. Основні особливості ринку нерухомості, характерні для економіки України на сучасному етапі розвитку

\begin{tabular}{|c|c|c|c|}
\hline $\begin{array}{l}\text { Напрям } \\
\text { аналізу }\end{array}$ & $\begin{array}{c}\text { Особливості ринку } \\
\text { нерухомості }\end{array}$ & Причини & Наслідки \\
\hline Правовий & $\begin{array}{l}\text { Регіональна } \\
\text { різноманітність }\end{array}$ & $\begin{array}{l}\text { - на регіональному рівні } \\
\text { відносини недостатньо } \\
\text { врегульовані }\end{array}$ & $\begin{array}{l}\text { - різниця в інвестиційній } \\
\text { привабливості об'єктів } \\
\text { нерухомості в різних } \\
\text { регіонах }\end{array}$ \\
\hline Структурний & $\begin{array}{l}\text { Структурна } \\
\text { неоднорідність }\end{array}$ & $\begin{array}{l}\text { - надвисока ціна об’єктів } \\
\text { первинного ринку } \\
\text { нерухомості }\end{array}$ & $\begin{array}{l}\text { - ринок землі практично } \\
\text { нерозвинений; } \\
\text { - розвиток ринку } \\
\text { промислової нерухомості } \\
\text { відбувається повільно }\end{array}$ \\
\hline Економічний & $\begin{array}{l}\text { Невідповідність } \\
\text { вартості нерухомості } \\
\text { фінансовим } \\
\text { можливостям } \\
\text { більшості населення }\end{array}$ & $\begin{array}{l}\text { - повільне зростання } \\
\text { реальних доходів } \\
\text { населення; } \\
\text { - недостатній розвиток } \\
\text { іпотечного } \\
\text { кредитування; } \\
\text { - завищення цін на деякі } \\
\text { види нерухомості }\end{array}$ & $\begin{array}{l}\text { - обмеженість інвестиційних } \\
\text { ресурсів на ринку; } \\
\text { - перенасичення первинного } \\
\text { ринку нерухомості }\end{array}$ \\
\hline Ефективність & $\begin{array}{l}\text { Неефективне } \\
\text { використання } \\
\text { основної частини } \\
\text { землі та будівель }\end{array}$ & $\begin{array}{l}\text { - будівництво більшості } \\
\text { об'єктів без урахування } \\
\text { сучасних ринкових } \\
\text { потреб }\end{array}$ & $\begin{array}{l}\text { - необхідність масштабної } \\
\text { реконструкції будівель і } \\
\text { споруд }\end{array}$ \\
\hline
\end{tabular}

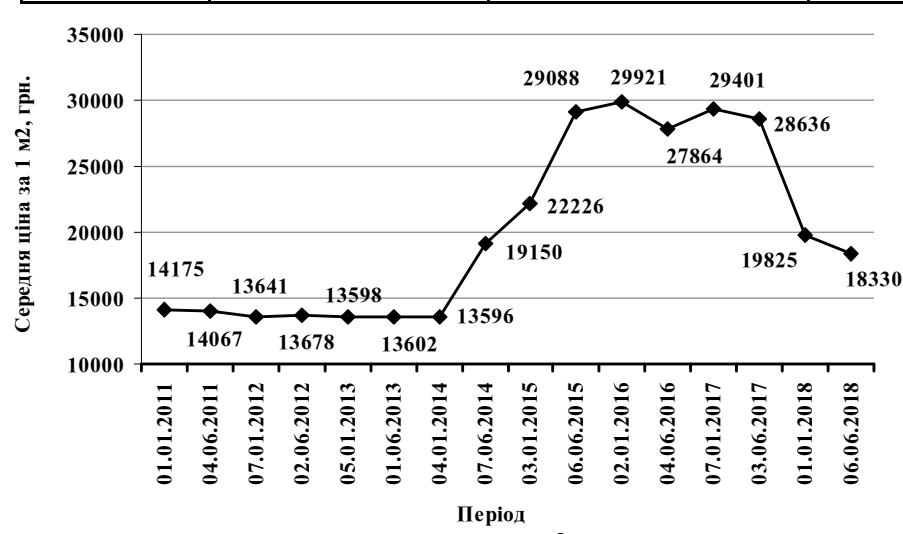

Рис. 1. Тенденція середньої ціни 1 м² нерухомості у м. Києві, 2011-2018 pp.

Ажерело: складено автором на основі офіційного сайту нерухомості в Україні. [Електронний ресурс]. — Режим доступу: http:// www.domik.ua

Таблиця 2. Середні ціни виставлених на продаж квартир за розташуванням і кількістю кімнат, вересень 2018 р.

\begin{tabular}{|c|c|c|c|c|c|c|c|c|c|}
\hline $\begin{array}{c}\text { Розта- } \\
\text { шування }\end{array}$ & $\begin{array}{l}\text { К-сть } \\
\text { кімнат }\end{array}$ & $\begin{array}{c}\text { К-сть } \\
\text { квартир }\end{array}$ & $\begin{array}{c}\text { Сер. заг } \\
\text { пл., кв. м }\end{array}$ & $\begin{array}{l}\text { Сер. ціна, } \\
\text { грн }\end{array}$ & $\begin{array}{l}\text { Сер. ціна, } \\
\text { грн/кв. м }\end{array}$ & $\begin{array}{c}\text { Зміни } \\
\text { в \% }\end{array}$ & $\begin{array}{l}\text { Cер. } \\
\text { ціна, \$ }\end{array}$ & $\begin{array}{c}\text { Cер. } \\
\text { ціна, } \\
\$ / \text { кв. м }\end{array}$ & $\begin{array}{c}\text { 3міни } \\
\text { в \% }\end{array}$ \\
\hline \multicolumn{2}{|c|}{ Загалом по Києву } & 18060 & 71 & 2610432 & 34852 & 0,4 & 92733 & 1238 & $-0,1$ \\
\hline \multicolumn{2}{|c|}{ Лівий берег } & 5604 & 67 & 1808357 & 27162 & 0,5 & 64240 & 965 & 0,0 \\
\hline & 1-кімн. & 1612 & 42 & 1205457 & 28637 & 0,5 & 42823 & 1017 & 0,0 \\
\hline & 2-кімн. & 1697 & 62 & 1731870 & 27730 & 0,7 & 61523 & 985 & 0,1 \\
\hline & 3-кімн. & 1919 & 84 & 2200092 & 25785 & 0,5 & 78156 & 916 & 0,0 \\
\hline & 4-кімн. & 376 & 106 & 2739037 & 25311 & 0,4 & 97301 & 899 & $-0,1$ \\
\hline \multicolumn{2}{|c|}{ Правий берег } & 8938 & 68 & 2263444 & 31864 & 0,8 & 80407 & 1132 & 0,3 \\
\hline & 1-кімн. & 2400 & 41 & 1321168 & 31582 & 1,3 & 46933 & 1122 & 0,7 \\
\hline & 2-кімн. & 2940 & 62 & 2052217 & 32047 & 1,1 & 72903 & 1138 & 0,6 \\
\hline & 3-кімн. & 3007 & 86 & 2862370 & 31662 & 0,2 & 101683 & 1125 & $-0,4$ \\
\hline & 4-кімн. & 591 & 117 & 4093397 & 33133 & 0,3 & 145414 & 1177 & $-0,2$ \\
\hline \multicolumn{2}{|l|}{ Центр } & 3518 & 86 & 4769673 & 54694 & 1,2 & 169438 & 1943 & 0,6 \\
\hline & 1-кімн. & 662 & 48 & 2511588 & 52159 & $-0,4$ & 89222 & 1853 & $-1,0$ \\
\hline & 2-кімн. & 1226 & 71 & 4009218 & 55884 & 1,8 & 142423 & 1985 & 1,2 \\
\hline & 3-кімн. & 1272 & 104 & 5826778 & 55009 & 1,1 & 206990 & 1954 & 0,6 \\
\hline & 4-кімн. & 358 & 144 & 7793508 & 54186 & 1,5 & 276856 & 1925 & 1,0 \\
\hline
\end{tabular}

Ажерело: [11]. ного моменту слід розуміти напрям і ступінь зміни сукупності елементів народногосподарського життя порівняно $з$ попереднім моментом" [6].

Ринок нерухомості в Україні перебуває на початкових етапах формування. В структурі ринку нерухомості за числом проведених операцій купівлі-продажу на сьогодні можна виділити такі групи об'єктів нерухомості: житлова нерухомість, нежитлова (комерційна) нерухомість; земельні ділянки несільськогосподарського використання. У секторі ринку житлової нерухомості найбільш масовими є операції з оцінки і купівлі-продажу квартир, будинків, котеджів, дач. У секторі нежитлової (комерційної) нерухомості - офіси, торговельні обєкти, склади, об'єкти малого бізнесу. Ринок земельних ділянок несільськогосподарського використання функціонує як база для подальшого формування об'єктів як житлової, так і нежитлової нерухомості. На сьогодні в структурі ринку нерухомості можна також виділити ринок об'єктів незавершеного будівництва, значна частина яких була розпочата ще за радянських часів. Окремий сектор становить ринок виробничих об'єктів, цілісних майнових комплексів, на яких здійснюється підприємницька діяльність і формуються господарські та фінансові результати [7].

Процеси функціонування ринку нерухомості постійно перебувають у центрі уваги науковців, які досліджують різноманітні аспекти проблеми, пов'язані з управлінням комерційною нерухомістю, визначенням їі вартості, аналізом інвестиційних особливостей окремих ринкових сегментів [8, с. 40-43]. Вивчення кон'юнктури ринку нерухомості вимагає дослідження чинників, що визначають динаміку платоспроможного попиту та пропозиції. Тобто глибокий і всебічний аналіз кон'юнктури ринку нерухомості стає важливим елементом системи управління.

Аналіз особливостей, притаманних ринку нерухомості $\mathrm{V}_{\mathrm{K}}$ раїни, дозволяє представити їх сутність, причини та наслідки у вигляді таблиці [9, с. 15-17].

Аналіз даних табл. 1 дозволяє зробити висновок, що ринок нерухомості в Україні є вкрай неоднорідним. В його структурі основними об'єктами угод, пов'язаних 3 операціями купівліпродажу, оренди тощо, є квартири та земельні ділянки. Тому основний інтерес для дослідження ринку нерухомості України представляє саме ринок житлової нерухомості (квартир) та ринок земель, організацією та забезпеченням функціонування якого опікується законодавець.

Ціна на нерухомість, як кон'юнктурний показник $є$ одним із багатьох індикаторів національної економіки, що характеризують стан та динаміку економічних процесів, які відбуваються у різних сегментах внутрішнього ринку України. Однією із вагомих соціально значимих складових $є$ ринок житлової нерухомості 
(РЖН). При дослідженні ринку житлової нерухомості основну увагу приділяють макроекономічним факторам, які є визначальними в процесі ціноутворення, оскільки кінцева ринкова ціна формується саме ринком, а не фахівцем-оцінювачем $[10$, с. 3]. Ао постійно діючих макроекономічних факторів, що безпосередньо впливають на рівень платоспроможного попиту, а отже, і на формування ціни на РЖН, є доходи населення. При цьому дія цієї складової за територіальною ознакою проявляє себе як на національному, так і на регіональному та локальному РЖНН.

Цінова тенденція на ринку нерухомості за період 2011-2018 рр. (рис. 1).

Аналіз рисунку свідчить про наступну цінову тенденцію на нерухомість: зростання ціни з червня 2014 по січень 2016 рр., стрімкий спад - у червні 2016 р., який уповільнився в 2016-2018 роках. Але незважаючи на спад, ціни залишаються надто великими по відношенню до платоспроможності населення України. Коливання валютного курсу призвів до неоднозначності ціни на нерухомість в гривнях та доларах. Аинаміка середньої ціни пропозиції квартир на ринку житла в Києва з січня 2018 року зменшилися в гривнях на $2,1 \%$, а в доларах збільшилась на $0,5 \%$. Порівняно з серпнем, середня ціна пропозиції 20\% квартир як низького цінового сегменту так і високого зросла - на 0,7\%, до 19874 грн /кв. м і на 0,4\%, до 60607 грн / кв. м відповідно. У доларовому еквіваленті ціни на квартири збільшилися у "дешевому" сегменті на 0,1\% до 706 дол. США/ кв. м та зменшилися у "дорогому" сегменті на $0,1 \%$ до 2153 дол. / кв. м відповідно. Вартість 1 кв. м "дешевого" і "дорогого" житла на вторинному ринку житлової нерухомості в Києві за рік зменшилися у "дорогому" сегменті житла на $6,1 \%$, а в "дешевому" - на 7,1\%. У доларовому еквіваленті ціни на квартири знизилися у "дорогому" сегменті на 7,4\%, у "дешевому" - на 8,3\%.

За минулий місяць у національній валюті зафіксовано зростання середніх цін у всіх адміністративних районах Києва - від $0,1 \%$ у Аніпровському до $2 \%$ у Солом'янському районах.

У доларовому еквіваленті середня ціна зменшилася в Аніпровському - на $0,4 \%$, в інших районах виросла: від $0,1 \%$ до $1,4 \%$.

Загальна ситуація на вторинному ринку житла. Кількість виставлених на продаж квартир у вересні збільшилася на $1,5 \%$, порівняно з серпнем, і склала 18060 квартир. Обсяг пропозиції збільшився у загальній площі — на $0,8 \%$, у доларовому вираженні - на $0,6 \%$.

Пропозиція квартир, порівняно з вереснем 2017 року, зменшилася на 10,7\%. Індекс росту склав 0,89 .

Частка квартир, вперше виставлених на продаж, у звітному місяці склала 10,2\% від усього обсягу пропозиції. Середня ціна пропозиції "нових" квартир у Києві на 3,5\% нижча за середню ціну серпня і становить 33492 грн/кв. м. У доларовому еквіваленті - нижча на 4\%, 1290 дол. США/кв. м.

Медіанна ціна квадратного метру житла зросла за місяць на 0,7\%, до 1068 дол. США/кв. м, а порівняно з січнем 2018 року - на $1,4 \%$, за рік зменшилась - на $0,3 \%$.

У структурі пропозиції житлової нерухомості переважають квартири, розташовані на Правому березі - 50\%. Квартири, розташовані на $\Lambda$ івому березі складають $31 \%$ від загальної кількості, в Центрі Києва - 19\%.

Збільшення кількості квартир спостерігалося на $\Lambda$ івому березі - на $0,4 \%$, на Правому березі на $3,7 \%$. Зменшення в Центрі Києва — на 2,1\%.
Таблиця 3. Середні ціни виставлених на продаж квартир на вторинному ринку житлової нерухомості Києва, вересень 2018 р.

\begin{tabular}{|c|c|c|c|c|c|c|c|c|c|}
\hline Район & $\begin{array}{c}\text { К-сть } \\
\text { кімнат }\end{array}$ & $\begin{array}{c}\text { К-сть } \\
\text { квартир }\end{array}$ & $\begin{array}{l}\text { Сер. заг. } \\
\text { пл., кв. м }\end{array}$ & $\begin{array}{c}\text { Сер. ціна, } \\
\text { грн }\end{array}$ & $\begin{array}{c}\text { Cер. } \\
\text { ціна, } \\
\text { грн/кв. м }\end{array}$ & Зміни & $\begin{array}{c}\text { Cер. } \\
\text { ціна, \$ }\end{array}$ & $\begin{array}{l}\text { Cер. } \\
\text { ціна, } \\
\$ / \text { кв. м }\end{array}$ & $\begin{array}{l}\text { Зміни } \\
\text { в \% }\end{array}$ \\
\hline \multicolumn{2}{|c|}{ Загалом по Києву } & 18060 & 71 & 2610432 & 34852 & 0,4 & 92733 & 1238 & $-0,1$ \\
\hline & 1-кімн. & 4674 & 42 & 1449865 & 33481 & $-0,1$ & 51505 & 1189 & $-0,7$ \\
\hline & 2-кімн. & 5863 & 64 & 2368720 & 35782 & 0,9 & 84146 & 1271 & 0,4 \\
\hline & 3-кімн. & 6198 & 89 & 3265696 & 34634 & 0,5 & 116011 & 1230 & 0,0 \\
\hline & 4-кімн. & 1325 & 121 & 4708793 & 36602 & $-0,3$ & 167275 & 1300 & $-0,8$ \\
\hline \multicolumn{2}{|c|}{ Голосіївський } & 2467 & 72 & 2533174 & 34063 & 0,7 & 89988 & 1210 & 0,1 \\
\hline & 1-кімн. & 700 & 42 & 1372423 & 32000 & 0,6 & 48754 & 1137 & 0,0 \\
\hline & 2-кімн. & 803 & 65 & 2316571 & 34863 & 0,9 & 82294 & 1238 & 0,3 \\
\hline & 3-кімн. & 814 & 92 & 3315665 & 34700 & 0,5 & 117786 & 1233 & 0,0 \\
\hline & 4-кімн. & 150 & 129 & 4863246 & 35949 & 0,6 & 172762 & 1277 & 0,0 \\
\hline \multicolumn{2}{|c|}{ Дарницький } & 2631 & 71 & 2002038 & 28270 & 0,9 & 71120 & 1004 & 0,4 \\
\hline & 1-кімн. & 748 & 43 & 1274452 & 29596 & 0,9 & 45274 & 1051 & 0,3 \\
\hline & 2-кімн. & 774 & 66 & 1937916 & 29161 & 1,6 & 68842 & 1036 & 1,1 \\
\hline & 3-кімн. & 924 & 90 & 2454555 & 26943 & 0,7 & 87196 & 957 & 0,2 \\
\hline & 4-кімн. & 185 & 113 & 2951982 & 25807 & $-0,2$ & 104866 & 917 & $-0,7$ \\
\hline \multicolumn{2}{|c|}{ Деснянський } & 991 & 64 & 1472942 & 23271 & 0,9 & 52325 & 827 & 0,4 \\
\hline & 1-кімн. & 237 & 39 & 963748 & 24974 & 0,9 & 34236 & 887 & 0,3 \\
\hline & 2-кімн. & 273 & 58 & 1430413 & 24607 & 0,7 & 50814 & 874 & 0,2 \\
\hline & 3-кімн. & 399 & 78 & 1716096 & 21889 & 1,0 & 60963 & 778 & 0,5 \\
\hline & 4-кімн. & 82 & 92 & 1903077 & 20629 & 1,3 & 67605 & 733 & 0,7 \\
\hline \multicolumn{2}{|c|}{ Дніпровський } & 1982 & 62 & 1718964 & 27638 & 0,1 & 61064 & 982 & $-0,4$ \\
\hline & 1-кімн. & 627 & 42 & 1214511 & 28878 & 0,3 & 43144 & 1026 & $-0,2$ \\
\hline & 2-кімн. & 650 & 59 & 1613129 & 27338 & $-0,4$ & 57305 & 971 & $-1,0$ \\
\hline & 3-кімн. & 596 & 78 & 2129606 & 26595 & 0,1 & 75652 & 945 & $-0,4$ \\
\hline & 4-кімн. & 109 & 105 & 3006505 & 27992 & 2,7 & 106803 & 994 & 2,1 \\
\hline \multicolumn{2}{|c|}{ Оболонський } & 1184 & 68 & 2484858 & 34628 & 0,6 & 88272 & 1230 & 0,1 \\
\hline & 1-кімн. & 287 & 41 & 1452926 & 34839 & $-0,2$ & 51614 & 1238 & $-0,8$ \\
\hline & 2-кімн. & 346 & 61 & 2161868 & 34658 & 1,6 & 76798 & 1231 & 1,1 \\
\hline & 3-кімн. & 460 & 82 & 2963995 & 33818 & 0,7 & 105293 & 1201 & 0,1 \\
\hline & 4-кімн. & 91 & 112 & 4545472 & 37946 & $-0,7$ & 161473 & 1348 & $-1,2$ \\
\hline \multicolumn{2}{|c|}{ Печерський } & 2371 & 85 & 4844602 & 55689 & 0,6 & 172100 & 1978 & 0,1 \\
\hline & 1-кімн. & 491 & 49 & 2596361 & 52649 & $-0,5$ & 92233 & 1870 & $-1,0$ \\
\hline & 2-кімн. & 869 & 73 & 4175778 & 56312 & 0,3 & 148340 & 2000 & $-0,3$ \\
\hline & 3-кімн. & 817 & 106 & 6148983 & 56892 & 1,1 & 218436 & 2021 & 0,5 \\
\hline & 4-кімн. & 194 & 145 & 8037458 & 55528 & 1,5 & 285523 & 1973 & 0,9 \\
\hline \multicolumn{2}{|c|}{ Подільський } & 1099 & 65 & 2108648 & 31168 & 1,3 & 74908 & 1107 & 0,8 \\
\hline & 1-кімн. & 310 & 40 & 1210216 & 30242 & 1,8 & 42992 & 1074 & 1,3 \\
\hline & 2-кімн. & 361 & 62 & 2042255 & 32057 & 2,4 & 72549 & 1139 & 1,9 \\
\hline & 3-кімн. & 363 & 82 & 2607760 & 30786 & 0,0 & 92638 & 1094 & $-0,5$ \\
\hline & 4-кімн. & 65 & 115 & 3974860 & 32769 & 0,3 & 141203 & 1164 & $-0,2$ \\
\hline \multicolumn{2}{|c|}{ Святошинський } & 1339 & 64 & 1677452 & 26110 & 1,3 & 59590 & 928 & 0,7 \\
\hline & 1-кімн. & 354 & 39 & 1051340 & 27081 & 0,1 & 37348 & 962 & $-0,5$ \\
\hline & 2-кімн. & 407 & 60 & 1560715 & 25810 & 2,2 & 55443 & 917 & 1,7 \\
\hline & 3-кімн. & 469 & 78 & 2046988 & 25818 & 1,4 & 72717 & 917 & 0,8 \\
\hline & 4-кімн. & 109 & 98 & 2556743 & 25332 & 2,0 & 90826 & 900 & 1,5 \\
\hline \multicolumn{2}{|c|}{ Солом'янський } & 1728 & 69 & 2268121 & 31640 & 2,0 & 80573 & 1124 & 1,4 \\
\hline & 1-кімн. & 455 & 43 & 1421030 & 32573 & 3,3 & 50481 & 1157 & 2,8 \\
\hline & 2-кімн. & 583 & 60 & 1975705 & 31696 & 1,5 & 70185 & 1126 & 0,9 \\
\hline & 3-кімн. & 568 & 89 & 2863562 & 30803 & 1,6 & 101725 & 1094 & 1,1 \\
\hline & 4-кімн. & 122 & 123 & 4052501 & 31792 & 1,0 & 143961 & 1129 & 0,4 \\
\hline \multicolumn{2}{|c|}{ Шевченківський } & 2268 & 77 & 3461017 & 42441 & 0,9 & 122949 & 1508 & 0,4 \\
\hline & 1-кімн. & 465 & 42 & 1692612 & 39343 & 1,3 & 60128 & 1398 & 0,8 \\
\hline & 2-кімн. & 797 & 64 & 2744737 & 41724 & 1,3 & 97504 & 1482 & 0,7 \\
\hline & 3-кіімн. & 788 & 96 & 4314140 & 43294 & 0,7 & 153255 & 1538 & 0,1 \\
\hline & 4-кімн. & 218 & 137 & 6768007 & 48590 & 1,7 & 240427 & 1726 & 1,1 \\
\hline
\end{tabular}

Ажерело: [11] 
Аналіз пропозиції з розподілом за кількістю кімнат по Києву показує, що в загальному обсязі однокімнатні квартири займають $26 \%$, двокімнатні - 33\%, трикімнатні - 34\% і 4-кімнатні - 7\%.

Порівняно 3 попереднім місяцем збільшилася кількість однокімнатних квартир - на 0,7\%, двокімнатних - на 2\%, трикімнатних - на 2,2\%, чотирикімнатних зменшилась - на $1,3 \%$.

Найбільша кількість квартир пропонувалася у Аарницькому районі - 15\%. У Голосіївському - 14\%, Печерському та Шевченківському - по 13\%, в Аніпровському $-11 \%$, і Солом'янському $-10 \%$. Найменша частка виставлених на продаж квартир: в Святошинському - 7\%, Оболонському та Подільському — по 6\%, у Аеснянському $-5 \%$.

Зменшення пропозиції спостерігалося в Аарницькому - на $0,1 \%$, Аніпровському - на $1,1 \%$ та в Печерському - на 4,4\%. В інших районах зростання кількості квартир склало: від 0,6\% в Солом'янському, до 8,6\% у Голосіївському районі.

У структурі пропозиції, за повними цінами за об'єкт, переважають квартири у ціновій категорії від 50 до 100 тис. дол. США - 43\%. Ао 50 тис. дол. США - 28\%. У ціновій категорії від 100 до 150 тис. дол. США - 14\%, від 150 до 250 тис. дол. США - $10 \%$ і від 250 тис. дол. США - 5\%.

Перевищення пропозиції на первинному ринку житла Києва над попитом існує, але говорити про обвал цін на ринку нерухомості немає підстав. Зростання пропозиції над попитом безумовно є, але результат масової забудови і повної відсутності контролю з боку міста та покарання недобросовісних забудовників приводить до неякісного будівництва. Сьогодні на продаж пропонуються квартири, які будуть введені в експлуатацію не раніше кінця 2018 початку 2019 років. Сьогодні на ринку житла в Україні поступово вимальовується досить суперечлива ситуація. Більшість покупців не має достатньо грошей для купівлі великих квартир, вартість яких $є$ досить високою. Таким чином, зростає попит на квартири-студії, смарт-житло і нерухомість маленької площі. У забудовників, які готують свої будинки для здачі в експлуатацію, вже немає можливості змінити проекти і запропонувати покупцям менше і, відповідно, дешевше жкитло. Головна проблема, яка існує зараз на ринку нерухомості, полягає у значному перевищенні сукупної пропозиції в порівнянні з сукупним платоспроможним попит населення України.

\section{ВИСНОВоК}

Ринок нерухомості - це важлива складова будьякого національної ринку та світового в цілому. Важливе значення вітчизняного ринку нерухомості як сегменту національного ринку України підтверджується, в першу чергу, високою його вартісною часткою в структурі національного багатства. Вивчення кон'юнктури ринку нерухомості дозволяє визначитись $з$ тенденціями щодо руху фінансових ресурсів між покупцями та продавцями, між орендаторами та власниками нерухомості, між споживанням та інвестиціями на макроекономічному рівні. Можна спрогнозувати надходження у вигляді податків та зборів - до бюджету; надходження до бюджету від первинного продажу об'єктів, здачі в оренду державної та комунальної нерухомості (зокрема землі); кількість робочих місць, створених у ході становлення та розвитку ринку нерухомості.

За результатами дослідження можемо зробити висновок, що дуже загострилась проблема забезпечення населення України соціальним житлом. В умовах, коли пропозиція перевищує платоспроможний попит на ринку нерухомості, ціни не змінюються відповідним чином, що засвідчує недосконалість самого ринкового механізму й невідповідність кон'юнктури пропозиції до потреб населення. Роль держави якраз й полягає в тому, щоб запровадити інструменти активізації ринку нерухомості через використання фінансового механізму.
Мітература:

1. Асаул A.M. Ринок нерухомості: навч. посіб./ A.M. Асаул, B.I. Павлов, I.I. Пилипенко, та ін. - К., 2004. - C. 17.

2. Борисов А.Б. Большой энциклопедический словарь / А.Б. Борисов (авт.-сост.). - М.: Книжный мир, 1999. -896 c.

3. Пископпель Ф.Г. Основы изучения конъюнктуры капиталистического хозяйства / Ф.Г. Пископпель. М.: Иза-во ИМО, 1960. - 302 с.

4. Мочерний С.В. Економічна енциклопедія: У трьох томах. - Т. 2. / Ред. кол.: С.В. Мочерний (відп. ред.) та ін. - К.: Видавничий центр "Академія", 2000. - 864 с.

5. Репке В. Конъюнктура / Под ред. А.А. Вайнштейна.- М.: Финанс.изд. НКФ СССР, 1927. - 171 с.

6. Кондратьев Н.А. Большие циклы конъюнктуры. Избранные сочинения / Ред. колл. А.И. Абалкин и др. М.: Экономика, 1993. - 526 с.

7. Асаул А.М. Економіка нерухомості: підручник / A.M. Асаул, I.А. Брижань, В.Я. Чевганова. - К.: Аібра, 2004. - 304 c.

8. Завора Т. Ринок нерухомості та особливості його функціонування / Т. Завора // Економіст. - 2006. № 10 . - C. $40-43$.

9. Манн Р.В. Особливості діагностування стану і перспектив розвитку ринку нерухомості/ Р.В. Манн // Економіка та держава: наук.-практ. журнал. - 2011. № 9. - С. $15-17$.

10. Рейкін В.С. Інформація аналітичного центру газети / В.С. Рейкін // Волинський спеціалізований рекламно-інформаційний тижневик "Експрес нерухомість". -2009 . - № 4 (328). - С. 3.

11. Столична нерухомість: 100realty.ua. Аналіз цін вторинного ринку житлової нерухомості Києва / На основі даних від АН "Благовіст" і АН ParkLane. - 2018 р. [Електронний ресурс]. - Режим доступу: https:// 100realty.ua/uk/analytics/ 47166

References:

1. Asaul, A. M. Bryzhan', I. A. and Chevhanova, V. Ya., (2004), Ekonomika nerukhomosti: pidruchnyk [Real Estate Economics: Textbook], Libra, Kyiv, Ukraine.

2. Asaul, A.M. Pavlov, V. I. and Pylypenko, I. I. (2004), Rynok nerukhomosti: navch. posib. [Real estate market], Kyiv, Ukraine.

3. Borysov, A.B. (1999), Bol'shoj entsyklopedycheskyj slovar' [Big Encyclopedic Dictionary], Knyzhnyj myr, Moscow, Russia.

4. Kondrat'ev, N.D. (1993), Bol'shye tsykly kon'iunktury. Yzbrannye sochynenyia [Big cycles of conjuncture. Selected writings], Ekonomyka, Moscow, Russia.

5. Mochernyj, S.V. (2000), Ekonomichna entsyklopediia: U tr'okh tomakh. T. 2. [Economic Encyclopedia: In three volumes. T. 2], Vydavnychyj tsentr "Akademiia", Kyiv, Ukraine.

6. Pyskoppel', F.H. (1960), Osnovy yzuchenyia kon'iunktury kapytalystycheskoho khoziajstva [Fundamentals of studying the conjuncture of the capitalist economy], YMO, Moscow, Russia.

7. Repke, V. (1927), Kon'iunktura [Conjuncture], Fynans.yzd. NKF SSSR, Moscow, Russia.

8. Mann, R.V. (2011), "Features of diagnosing the state and prospects of the real estate market", Ekonomika ta derzhava, vol. 9, pp. 15-17.

9. Rejkin, V.S. (2009), "Information of the analytical center of the newspaper", Ekspres nerukhomist', vol. 4, pp. 3.

10. Zavora, T. (2006), "Real estate market and features of its functioning", Ekonomist, vol. 10, pp. 40-43.

11. Stolychna nerukhomist': 100realty.ua. (2018), "Analysis of prices of the secondary market of residential real estate in Kiev", available at: https://100realty.ua/uk/ analytitss/ 47166 (Accessed 20 September 2018).

Стаття надійила до редакиї 09.11.2018 p. 
O. A. Пempyx, аспірант кафедри менеджменту, Аъвівсъкий начіональний університет імені Івана Франка, м. Аъвів

DOI: $10.32702 / 2306-6806.2018 .11 .107$

\section{ІННОВАЦІЙНИЙ РОЗВИТОК СФЕРИ ОХОРОНИ ЗАОРОВ'Я УКРАЇНИ}

O. Petruch,

PhD Student, Ivan Franko Lviv national university

\section{INNOVATIVE DEVELOPMENT OF UKRAINE'S HEALTHCARE SECTOR}

Устатті запропоновано кАасифікацію інновацій у сфері охорони здоров'я України за такими категоріями, як напрям спрямування, рівень прояву чи спроможності, до поширення, ступінь трансформації новизни, рівень системи заходів, що спрямовані на охорону здоров'я, підгрунтя виникнення, ступінь розвитку сфери охорони здоров'я. Виокремиено суб'єкти сфери охорони здоров'я України та основні сектори, які ця важАива сфера охопиює. Виділено структурно-функціональні характеристики інноваційного розвитку сфери охорони здоров'я за такими критеріями: елементи соціальної функції та ознаки інноваційної діяльності сфери охорони здоров'я. Запропоновано властивості та форми інноваційної діяльності у сфері охорони здоров'я та напрями інноваційної діяльності для підвищення ефективності використання інноваційного потенціалу у сфері охорони здоров'я України.

In thearticle, the classification of innovations in the Ukraine's healthcare sector has been proposed. Classification includes the following categories: direction (foodstuff, process, consumer, market), level of manifestation orability to spread (international (mega level), national (macro level), tenitorial, regional, local (micro level, level of business entities, market segment), point (level of person, consumer), degree of novelty transformation (whole, relative, conditional, subjective), level of the measures system aimed at healthcare (organizational and technical, economic, therapeutic and prophylactic, sanitary and hygienic), basis for the emergence (international, strategic, complex, topical), degree of healthcare development (due to scientific and technological progress, due to the needs of the population, consumers, market). Definition of the concepts "healthcare", "healthcare innovations" and "innovative development of healthcare" have been proposed. The subjects of the Ukrainian healthcare sector and the main sectors that cover this important area have been singled out. The healthcare covers: sectors of activity; sectors of science; subjects providing affordable medical care for the population; entities regulating the activities of institutions, enterprises, organizations of healthcare (stateauthoritiesand local self-government bodies); subjects of innovative activity engaged in $R \& D$, production, sales of goods and medical supplies. Structuraland functionalcharacteristics of innovative development of the healthcare sector have been highlighted. These characteristics include the following criteria: elements of social function and signs of innovation in the healthcare sector. The allocation of structural and functional characteristics of the innovative development of healthcare is a key task for a general understanding of the peculiarities of innovative healthcare development in Ukraine. The features and forms of innovative activity in healthcare and directions of innovation activities aimed at increasing the efficiency of the use of innovative potential in the Ukraine's healthcare sector have been proposed.

Ключові слова: інновачї, інновачійний розвиток, срера охорони здоров' я, інновачійна діяльність, класифікація, суб'єкти.

Key words: innovation, innovation development, bealtbcare, innovation, classification, subjects.

\section{ПОСТАНОВКА ПРОБЛЕМИ}

Україна все ще суттєво відстає від своїх європейських сусідів за показником тривалість життя. Невпинно зростає й смертність посеред населення працездатного віку. Аержава витрачає значну частину ВВП на послуги охорони здоров'я, проте рівень ВВП на душу населення в Україні є нижчим, ніж у більшості європейських країн. Багатьом країнам все ж вдається досягати досить хороших показників тривалості життя та смертності, маючи зіставні витрати на охорону здоров'я та активно розвиваючи інноваційну діяльність у цій сфері.

\section{АНАЛІЗ ОСТАННІХ ДОСЛІДЖЕНЬ} І ПУБЛІКАЦІЙ

Проблеми інноваційних перетворень системи охорони здоров'я та результати їх розв'язання наведені у працях таких мислителів: А. Абрамешина, В. Баранчєєва, I. Борисенко, А. Бронштейна, А. Вишневського, А. Вялкова, Н. Герасименко, Н. Грищенко, А. Жаліло [1], В. Жарікова, С. Ільдеменова, Ф. Кадирова, Е. Кужель, О. Корнійчук [2], М. Мартинюк [1], Т. Овчиннікової, Ю. Салікова, $\Lambda$. Слєсарєва, А. Стігліц, В. Шевського та ін. Аналіз різнобічних питань державного регу- лювання інноваційної діяльності у системі охорони здоров'я був у об'єктиві вивчення багатьох економістів, зокрема, необхідно виділити таких: О. Амоша, Н. Артамова, I. Гладун,А. Карамишев, Р. Ааріна, В. Москаленко, В. Пашков, Г. Слабкий, І. Солоненко, 3. Юринець [5-7] та інші.

\section{ВИДІЛЕННЯ НЕ ВИРІШЕНИХ РАНІШЕ ЧАСТИН ЗАГАЛЬНОÏ ПРОБЛЕМИ}

У науковій літературі ще не належним чином висвітлено питання розроблення класифікації інновацій у сфері охорони здоров'я, виділення характерних рис інноваційної діяльності й інноваційного розвитку сфери охорони здоров'я, рекомендацій для підвищення ефективності використання інноваційного потенціалу у сфері охорони здоров'я.

\section{ФОРМУЛЮВАННЯ ЦІЛЕЙ СТАТТІ \\ (ПОСТАНОВКА ЗАВДАННЯ)}

Основною ціллю статті є розроблення класифікації інновацій у сфері охорони здоров'я, виокремлення структурно-функціональних характеристик інноваційного розвитку сфери охорони здоров'я, властивостей і форм інноваційної діяльності у сфері охорони здоро- 
Таблиця 1. Класифікація інновацій у сфері охорони здоров'я

\begin{tabular}{|c|c|c|}
\hline $\begin{array}{l}\text { № } \\
\text { ח/ח }\end{array}$ & Ознака & Тип \\
\hline 1 & $\begin{array}{l}\text { Напрям } \\
\text { спрямування }\end{array}$ & $\begin{array}{l}\text { - } \\
\text { продуктові (нові матеріали, вироби медичного } \\
\text { призначення лікарські засоби, препарати); } \\
\text { - процесні (нові медичні технології, техніки, } \\
\text { обладнання, програми, методи лікування, } \\
\text { діагностики та лікування); } \\
\text { - споживчі (нові медичні послуги, задоволення потреб } \\
\text { населення); } \\
\text { - }\end{array}$ \\
\hline 2 & $\begin{array}{l}\text { Рівень прояву чи } \\
\text { спроможності } \\
\text { до поширення }\end{array}$ & $\begin{array}{l}\text { - } \text { міжнаціональні (мегарівень); } \\
\text { - } \text { національні (макрорівень, рівень країни); } \\
\text { - } \text { територіальні, регіональні (мезорівень); } \\
\text { - } \text { локальні (мікрорівень, рівень суб'єктів } \\
\quad \text { господарювання, сегменту ринку); } \\
\text { - } \quad \text { точкові (рівень людини, споживача, нанорівень) }\end{array}$ \\
\hline 3 & $\begin{array}{l}\text { Ступінь } \\
\text { трансформації } \\
\text { новизни }\end{array}$ & $\begin{array}{l}\text { - } \text { цілковита (абсолютно нові ідеї); } \\
\text { - } \text { релятивна (відносна новизна, поліпшення інновацій, } \\
\text { рекомбінація елементів); } \\
\text { - умовна (нове сполучення елементів); } \\
\text { - суб'єктивна (новизна для споживачів, перше } \\
\text { ознайомлення з ним) }\end{array}$ \\
\hline 4 & $\begin{array}{l}\text { Рівень системи } \\
\text { заходів, що } \\
\text { спрямовані на } \\
\text { охорону здоров'я }\end{array}$ & $\begin{array}{l}\text { - організаційно-технічні; } \\
\text { - економічні, } \\
\text { - лікувально-профілактичні; } \\
\text { - санітарно-гігієнічні }\end{array}$ \\
\hline 5 & $\begin{array}{l}\text { Ступінь розвитку } \\
\text { сфери охорони } \\
\text { здоров'я }\end{array}$ & $\begin{array}{ll}\text { - } & \text { інтернаціональні; } \\
\text { - } & \text { стратегічні; } \\
\text { - } & \text { комплексні; } \\
\text { - } & \text { топічні (локальні) } \\
\end{array}$ \\
\hline 6 & $\begin{array}{l}\text { Підгрунтя } \\
\text { виникнення }\end{array}$ & $\begin{array}{ll}\text { - } & \text { внаслідок НТП; } \\
\text { - } & \text { внаслідок розвитку потреб населення, споживачів, ринку }\end{array}$ \\
\hline
\end{tabular}

Ажерело: укладено автором.

в'я, напрямів інноваційної діяльності для підвищення ефективності використання інноваційного потенціалу у сфері охорони здоров'я.

\section{ВИКЛАД ОСНОВНОГО МАТЕРІАЛУ ДОСЛІДЖЕННЯ}

Сфера охорони здоров'я - це сукупність установ, організацій, підприємств, управлінських органів усіх ієрархічних рівнів, що залучені до організації та забезпечення доступного медичного обслуговування населення, виробників товарів, предметів медичного призначення, для надання медичних послуг не залежно від форм власності використовуваних об'єктів.

Суб'єкти сфери охорони здоров'я: органи державної влади та місцевого самоврядування, заклади охорони здоров'я, підприємства-виробники товарів і предметів медичного призначення, науково-дослідні установи, освітні установи, інші підприємства й організації.

Сфера охорони здоров'я охоплює:

- сектори діяльності: медичний, біологічний та фармацевтичний;

- сектори науки: вузівський (медичні університети, коледжі тощо), академічний (академії медичних наук, науково-дослідні інститути тощо), відомчий (галузевий) і заводський;

- суб'єкти, що забезпечують доступне медичне обслуговування населення (заклади охорони здоров'я); суб'єкти, що регулюють діяльність закладів, підприємств, організацій у сфері охорони здоров'я (органи державної влади та органи місцевого самоврядування); суб'єкти інноваційної діяльності, що займаються НААКР, виробництвом, збутом товарів і предметів медичного призначення.

Безпосередньо питаннями охорони здоров'я громадян займаються лікувально-профілактичні, санітарнопрофілактичні, санаторно-курортні, аптечні, фізкультурно-оздоровчі, науково-медичні заклади охорони здоров'я тощо.

Інновації у сфері охорони здоров'я - це процес створення, одержання та комерціалізації результатів, який спонукає до матеріалізованих змін у сфері.

Пропонуємо виділяти соціальні інновації за економічними сферами і, таким чином, систематизувати інно- вації у сфері охорони здоров'я за різними ознаками (табл. 1).

Отже, інновації у сфері охорони здоров'я це результат інноваційної діяльності, що реалізується у вигляді забезпечення модернізації матеріально-технічної бази, впровадження новітніх прогресивних засобів і методів лікування, медичних технологій, виробів медичного призначення і лікарських засобів, удосконалення існуючих методів діагностики та лікування (медичні інновації), розробленні програмних засобів опрацювання інформації, створення нових моделей функціонування сфери охорони здоров'я і розвитку персоналу; має вплив на покращення здоров'я населення та економічних показників суб'єктів господарювання сфери охорони здоров'я.

Розкриття поняття інновації зумовлене практичним застосуванням у контексті здійснення інноваційного розвитку.

Інноваційний розвиток сфери охорони здоров'я доцільно охарактеризувати як нову модель організації та забезпечення доступного медичного обслуговування населення, що грунтується на інноваціях, характеризується ухваленням стратегічних рішень в інноваційній діяльності на всіх ієрархічних рівнях національної економіки.

Інноваційний розвиток сфери охорони здоров'я - динамічний процес структурного удосконалення сфери завдяки втіленню новітніх знань задля покращення якості надання медичних послуг, підвищення конкурентоспроможності суб'єктів господарювання сфери охорони здоров' я 3 орієнтацію на інноваційні перетворення.

Інноваційний розвиток сфери охорони здоров'я — це вагома та витратна для держави справа, яка потребує постійного удосконалення з метою поліпшення її функціонування та забезпечення виконання своїх соціальних функцій, що можливо за рахунок впровадження низки загальнонаціональних заходів та програм [183, с. 236]. Структурно-функціональні характеристики інноваційного розвитку сфери охорони здоров'я наведені у таблиці 2.

Узагальнюючи правові й економічні характеристики інноваційної діяльності, розглядаючи більш детально класифікації інноваційної діяльності в межах чинного законодавства України, можна виділити такі властивості та форми інноваційної діяльності у сфері охорони здоров'я (табл. 3).

Питання трансформації економічних засад інноваційного розвитку сфери охорони здоров'я мають бути спрямовані на формування зрозумілих фінансово-економічних механізмів цільового накопичення та адресного використання коштів, необхідних для реалізації в повному обсязі конституційних прав громадян на охорону здоров'я, медичну допомогу та медичне страхування $[1,7]$. Важливим у цьому напрямі є вирішення проблем кадрової політики удосконалення інноваційної політики з метою підвищення ефективності використання інноваційного потенціалу у сфері охорони здоров'я, розгляд і реалізацію напрямів інноваційної діяльності (рис. 1).

Основні напрями:

- Оптимізація і реструктуризація мережі, структури та основних напрямів діяльності науково-дослідних установ.

- Посилення ролі національної академії медичних наук України у провадженні пріоритетних фундаментальних і прикладних досліджень.

- Забезпечення розв'язання науково-практичних проблем охорони здоров'я шляхом формування відповідних державних, галузевих, міжгалузевих, регіональних програм.

- Запровадження багатоканальності фінансування медичної науки за рахунок бюджетних та позабюджетних коштів, забезпечення їх раціонального використання для першочергового фінансування конкурентоспро- 
Таблиця 2. Структурно-функціональні характеристики інноваційного розвитку сфери охорони здоров'я

\begin{tabular}{|c|c|c|}
\hline $\begin{array}{c}\text { № } \\
\Pi / \Pi\end{array}$ & Критерії & Характеристика \\
\hline 1 & $\begin{array}{l}\text { Елементи } \\
\text { соціальної } \\
\text { функції }\end{array}$ & $\begin{array}{l}\text { - створення системи стратегічного управління інноваційним } \\
\text { розвитком сфери охорони здоров'я України; } \\
\text { - збільшення обсягу наукових розробок за рахунок коштів } \\
\text { комерційних структур; } \\
\text { - проведення соціологічних та статистичних досліджень з метою оцінки } \\
\text { потреб суспільства в інноваціях, зокрема лікарських засобах; } \\
\text { - державний контроль щодо забезпечення необхідними якісними } \\
\text { медичними послугами усього населення; } \\
\text { - визначення законодавчо чіткого переліку медичної допомоги, що } \\
\text { повинна надаватися у державних закладах охорони здоров'я } \\
\text { безкоштовно та за відповідного фінансування цих закладів; } \\
\text { - створення зв'язків між фінансуванням державних закладів охорони } \\
\text { здоров'я і кінцевими результатами їх роботи; } \\
\text { - підвищення рівня фінансування сфери за рахунок розроблення та } \\
\text { реалізації механізму державно-приватного партнерства; } \\
\text { - нормативна розробка українських медичних стандартів згідно з } \\
\text { міжнародними стандартами якості надання медичних послуг; } \\
\text { - впровадження обов'язкового медичного страхування громадян; } \\
\text { - повернення наукового потенціалу України на вітчизняні терени }\end{array}$ \\
\hline 2 & $\begin{array}{l}\text { Ознаки } \\
\text { інноваційної } \\
\text { діяльності } \\
\text { сфери } \\
\text { охорони } \\
\text { здоров'я }\end{array}$ & $\begin{array}{l}\text { - основним предметом є впровадження, використання та } \\
\text { комерціалізація результатів наукових досліджень і розробок у } \\
\text { виробництві та соціальній сфері; } \\
\text { - об'єктом виступають нематеріальні блага - результати } \\
\text { інтелектуальної діяльності, які доводяться до стану інноваційного } \\
\text { продукту та впроваджуються як інновації; } \\
\text { - результати мають довгостроковий характер; } \\
\text { - властивий високий ступінь непередбачуваності наслідків та } \\
\text { результатів, що свідчить про її ризиковий характер; } \\
\text { - передбачає фінансування робіт із реалізації інноваційного проекту } \\
\text { щодо впровадження та використання результатів наукових досліджень і } \\
\text { розробок, тобто супроводжується інвестуванням грошових коштів у } \\
\text { нематеріальні об'єкти, що фактично становить інший елемент предмета } \\
\text { інноваційної діяльності; } \\
\text { - викликає позитивні соціально-економічні зміни; } \\
\text { - одним із результатів її здійснення є підвищення } \\
\text { конкурентоспроможності суб'єктів господарювання сфери охорони } \\
\text { здоров’я та продукції чи медичних послуг, що ними випускається чи } \\
\text { надається на основі реалізації інновацій }\end{array}$ \\
\hline
\end{tabular}

Таблиця 3. Властивості та форми інноваційної діяльності у сфері охорони здоров'я

\begin{tabular}{|c|c|}
\hline Критерії & $\begin{array}{c}\text { Характеристика властивостей і форм інноваційної діяльності у сфері } \\
\text { охорони здоров'я }\end{array}$ \\
\hline $\begin{array}{l}\text { Основні } \\
\text { властивості } \\
\text { здійснення } \\
\text { інноваційної } \\
\text { діяльності }\end{array}$ & $\begin{array}{l}\text { - основний предмет діяльності полягає в організації та здійсненні робіт з } \\
\text { доведення НДДКР, результатів інтелектуальної діяльності у сфері } \\
\text { охорони здоров'я до стану практичного використання, їх комерціалізація } \\
\text { та впровадження у виробництво й соціальну сферу; } \\
\text { - другорядним видом діяльності є інвестиційна діяльність, оскільки } \\
\text { необхідною умовою розроблення та реалізації нових результатів } \\
\text { інтелектуальної діяльності є фінансування реалізації інноваційного } \\
\text { проекту у сфери охорони здоров'я з їх впровадження та використання, } \\
\text { інвестування грошових коштів у нематеріальні об'єкти; } \\
\text { - об'єктом є нематеріальні блага - результати інтелектуальної діяльності } \\
\text { (результати НДДКР), які впроваджуються як інновації у сфері охорони } \\
\text { здоров'я; } \\
\text { - один із результатів їі здійснення полягає у підвищенні } \\
\text { конкурентоспроможності суб'єктів господарювання та інновацій у сфері } \\
\text { охорони здоров'я; } \\
\text { - наслідком здійснення інноваційної діяльності у сфері охорони здоров’я } \\
\text { є позитивні соціально-економічні зрушення, підвищення якості охорони } \\
\text { здоров'я, життя населення }\end{array}$ \\
\hline $\begin{array}{l}\text { Форми } \\
\text { здійснення } \\
\text { інноваційної } \\
\text { діяльності }\end{array}$ & $\begin{array}{l}\text { - державне (комунальне) здійснення інноваційної діяльності у сфері } \\
\text { охорони здоров'я, що здійснюється органами державної влади або } \\
\text { органами місцевого самоврядування за рахунок бюджетних коштів та } \\
\text { інших коштів відповідно до закону; } \\
\text { - комерційне здійснення інноваційної діяльності у сфері охорони } \\
\text { здоров'я, що здійснюється суб’єктами господарювання за рахунок } \\
\text { власних або позичкових коштів з метою розвитку бази підприємництва; } \\
\text { - соціальне здійснення інноваційної діяльності у сфері охорони здоров’я, } \\
\text { що здійснюється в об'єкти соціальної сфери та інших невиробничих } \\
\text { сфер; } \\
\text { - іноземне здійснення інноваційної діяльності у сфері охорони здоров’я, } \\
\text { що здійснюється іноземними юридичними особами або іноземцями, а } \\
\text { також іншими державами; } \\
\text { - спільне здійснення інноваційної діяльності у сфері охорони здоров'я, } \\
\text { що здійснюється суб'єктами України разом з іноземними юридичними } \\
\text { особами чи іноземцями }\end{array}$ \\
\hline
\end{tabular}

можних наукових розробок фундаментального та прикладного характеру.

- Планування наукових досліджень на конкурентних засадах та спрямування їх на отримання конкретних результатів, впровадження принципів незалежної експертизи наукових проектів та їх результатів, виділення спеціальних грантів під реалізацію проектів переможців конкурсу.

- Забезпечення підтримки визнаних вітчизняних наукових шкіл, підвищення вимог до підготовки наукових кадрів, раціональне використання науково-інформаційних ресурсів.

- Активізація роботи, спрямованої на забезпечення розвитку міжнародного науково-технічного співробітництва, яке сприятиме підвищенню авторитету вітчизняної медичної науки та ії інтеграції у світову спільноту.

- Реформування кадрової політики в сфері охорони здоров'я має бути спрямовано на: удосконалення системи кадрового забезпечення цієї сфери з урахуванням сучасних соціально-економічних умов та реальних потреб.

- Запровадження в установленому порядку укладання трудового договору на умовах контракту з керівниками закладів охорони здоров'я, а в подальшому - 3 усіма медичними працівниками; реорганізацію системи планування і розподілу кадрового потенціалу у співвідношенні "лікар - медичний працівник середньої ланки" шляхом збільшення кількості працівників середньої ланки.

- Реформування ступеневої медичної і фармацевтичної освіти.

- Здійснення підготовки фахівців за новими спеціальностями: медичний психолог, клінічний фармацевт, економіст охорони здоров'я, спеціаліст з інформатики охорони здоров'я, спеціаліст з експлуатації медичної техніки, менеджер охорони здоров'я.

- Розширення підготовки сімейних лікарів - лікарів загальної практики.

- Розроблення нових державних стандартів вищої медичної та фармацевтичної освіти, освітньо-кваліфікаційних характеристик фахівців, освітньо-професійних програм та засобів уніфікованої оцінки рівня знань медичних і фармацевтичних працівників.

- Удосконалення системи підготовки медичних сестер, розроблення та реалізація програми розвитку сестринства, розширення функцій медичних сестер відповідно до світового досвіду, що знизить потребу в лікарях у державі. 3 метою досягнення належного рівня здоров'я населення держава повинна забезпечити контроль за механізмами покращення обсягу та якості медичної допомоги, які поступово повинні збільшуватися за рахунок бюджетного фінансування та залучення додаткових джерел фінансування.

Таким чином, існуюча система охорони здоров'я потребує інноваційних перетворень, що торкаються усіх сфер діяльності, здатних підняти її на якісно новий рівень функціонування та розвитку. Тому на сьогоднішній час важливим для вирішення постає удосконалення системи державного регулювання інноваційного розвитку, програмно-цільового управління інноваційним розвитком сфери, фінансування охорони здоров'я в Україні. 


\section{ВИСНОВКИ}

Аля реалізації напрямів інноваційного розвитку сфери охорони здоров'я України потрібно застосувати класифікацію інновацій у сфері охорони здоров'я України, яку доцільно типізувати за такими категоріями, як напрям спрямування, рівень прояву чи спроможності до поширення, ступінь трансформації новизни, рівень системи заходів, що спрямовані на охорону здоров'я, підгрунтя виникнення, ступінь розвитку сфери охорони здоров'я. Ключовим завданням для загального розуміння особливостей інноваційного розвитку охорони здоров'я в Україні є виділення структурно-функціональних характеристик інноваційного розвитку сфери охорони здоров'я, які доцільно поділяти за такими критеріями, як елементи соціальної функції та ознаки інноваційної діяльності сфери охорони здоров'я. Запропоновані властивості, форми, напрями інноваційної діяльності у сфері охорони здоров'я сприятимуть підвищенню ефективності використання інноваційного потенціалу у сфері охорони здоров'я України, втіленню пріоритетних орієнтирів інноваційного розвитку цієї сфери.

\section{$\Lambda$ ітература:}

1. Жаліло М.І. Стратегї̈ змін у сфері охорони здоров'я в умовах соціально-економічних реформ в Україні / М.I. Жаліло, M.I. Мартинюк [Електронний ресурс]. - Режим доступу: http://www.academy.gov.ua/ej/ ej14/ txts/Zhalilo.pdf

2. Корнійчук О. Стратегія побудови сучасної української системи охорони здоров'я / О. Корнійчук // Вільне слово. - 2017 [Електронний ресурс]. - Режим доступу: https:// vilneslovo.com

3. Основи законодавства України про охорону здоров'я: Закон України від 19.11.1992 № 2801-XII [Електронний ресурс]. URL: http://zakon3.rada.gov.ua/laws/show/2801-12

4. Юринець 3.В., Круглякова В.В. Нейромережеве моделювання як інструмент прогнозування інноваційного розвитку економіки України // Актуальні проблеми економіки. - 2016. - № 6. - С. $425-432$.

5. Юринець 3.В. Формування інноваційних стратегій: теорія, методологія, практика: монографія. СПО $А$ OM, 2016. - 412 c.

6. Yurynets Z., Bayda B., Petruch O. Country's economic competitiveness increasing within innovation component. Economic Annals - XXI. - 2015. - № 910. - P. 32-35.

7. Yurynets Z. Forecasting model and assessment of the innovative and scientific-technical policy of Ukraine in the sphere of innovative economy formation. Investment $\mathrm{Ma}$ nagement and Financial Innovations. - 2016. - Vol. 13. № 2. - P. 16-23.

\section{References:}

1. Zhalilo, L. I. \& Martyniuk, M. I. "Strategies for healthcare change in conditions of social and economic reforms in Ukraine", available at: http://www.academy.gov.ua/ej/ej14/txts/Zhalilo.pdf[in Ukrainian]. працівників. $\rightarrow$ Оптимізація і реструктуризація мережі, структури та основних напрямів

$\rightarrow$ Посилення ролі національної академії медичних наук України у провадженні регіональних програм.

бюджетних та позабюджетних коштів, забезпечення їх раціонального укових розробок фундаментального та прикладного характеру.

отримання конкретних результатів, впровадження принципів незалежної

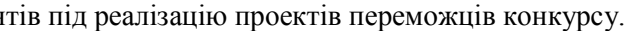
інформаційних ресурсів.

位

Запровадження в установленому порядку укладання трудового договору на

мовах контракту з керівниками закладів охорони здоров'я, а в подальшому - 3

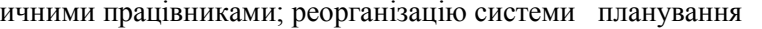

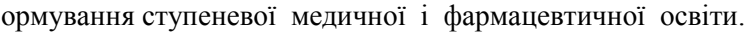
源 еджер охорони здоров'я. програм та засобів уніфікованої оцінки рівня знань медичних і фармацевтичних

програми розвитку сестринства, розширення функцій медичних сестер повідно до світового досвіду, що знизить потребу в лікарях у державі. 3 забезпечити контроль за механізмами покращення обсягу та якості медичної допомоги, які поступово повинні збільшуватися за рахунок бюджетного

\section{Рис. 1. Напрями інноваційної діяльності для підвищення ефективності} використання інноваційного потенціалу у сфері охорони здоров'я

Ажерело: укладено автором на основі $[1 ; 3 ; 5-7]$.

2. Korniychuk, O. (2017), "The strategy of building a modern Ukrainian healthcare system". Vilne slovo [Free word], available at: https://vilneslovo.com [in Ukrainian].

3. Fundamentals of Ukrainian legislation on healthcare: Law of Ukraine dated 19.11.1992 № 2801-XII, available at: http://zakon3.rada.gov.ua/laws/show/2801 (Accessed 3 October 2018).

4. Yurynets, Z. V. Krugliakova, V. V. (2016), Neural network modeling as a forecasting tool for innovative development of Ukraine's economy]. Aktualni problemy ekonomiky [Current problems of the economy]. №6. pp. 425-432. [in Ukrainian].

5. Yurynets, Z. (2016), Formation of innovative strategies: theory, methodology, practice: monograph. Lviv: SPOLOM. [in Ukrainian].

6. Yurynets, Z. Bayda, B. Petruch, O. (2015), Country's economic competitiveness increasing within innovation component. Economic Annals - XXI. № 9-10, pp. 32-35.

7. Yurynets, Z. (2016), Forecasting model and assessment of the innovative and scientific-technical policy of Ukraine in the sphere of innovative economy formation. Investment Management and Financial Innovations. Vol. 13. № 2, pp. 16-23.

Стаття надійила до редакиї 31.10.2018 p. 
I. С. Корженко, магістр кафедри міжнародних економічних відносин, Київський начіональний торговельно-економічний університет, м. Київ

\title{
ЗБУТОВА АІЯАЬНІСТЬ ПІАПРИЕМСТВА-ІМПОРТЕРА
}

\author{
I. Korzhenko,
}

Master of the International Economic Relations Department in Kyiv National University of Trade and Economics, Kiev

\section{SALES ACTIVITY OF THE IMPORTING COMPANY}

У статті досліджено сутність поняття "збутова діяльність" та визначено їі місце і роль у підвищенні ефективності,діяльості ПідприемСтв, що здійснюють зовнішньоекономічнУ,іяльність. РозГлянуто принципи формування збутової діяльності підприемства-суб'єкта зовнішньоекономічної діяльності: економічності, пАановості, синергізму, прибутковості, результативності, ефективності, системності, комплексності, соціальної відповідальності та стратегічної гнучкості. Розглянуто сутність кожного з вищенаведених принципів, Здійснено їх узагальнення. Проаналізовано функції збутової діяльності підприємствасуб'єкта міжнародного бізнесу (організування інформаційного забезпечення про стан ринку, проведення маркетингових досліджень і скАадання прогнозів збуту; підписання договорів на постачання продукціі; вибір форм і методів збуту, організування системи розподілу; створення комунікації та організування правового забезпечення; організування сервісного та післяпродажного обслуговування). Аосліджено переваги та недоліки існуючих підходів до формування збутової,іядьності підприємства. Визначено цілі процесу збуту продукції на підприємстві. Проаналізовано способи оптимізації процесу збуту на підприемстві.

The article explores the essence of the concept of "sales activity" and defines its place and role in improving the efficiency of enterprises engaged in foreign economic activity. The principles of forming the sales activity of the enterprise-subject of foreign economic activity: economics, planning, synergy, profitability, efficiency, efficiency, systemicity, complexity, social responsibility and strategic flexibility are considered. The essence of each of the above-mentioned principles is considered, their generalization is carried out. The functions of sales activity of the enterprise - the subject of in ternational business (organization of information provision on the state of the market, marketing research and forecasting of sales, signing of contracts for the supply of products, the choice of forms and methods of sales, the organization of distribution system, the creation of communication and the organization of legal support; organization of service and after-sales service). Goals of optimization of the sales process at the enterprise are determined (strengthening of positions in the existing market, creation of an effective system of stimulation of sales, development of an commodity or corporate brand, creation of internal competitive advantages, access to new markets, leadership in the existing market, increase profitability of sales, preservation of positions). Methods of optimization of the sales process are analyzed (development of methods of stimulation the consumer, reinvestment of profits into the production sphere of the enterprise, promotion of sales managers, active marketing, reinvestment of profits into brand development, promotion of middle management, mass marketing, opening of new shopping centers, search for new dealers, active marketing, rational use of active working capital, investments in the development of new technologies). The advantages and disadvantages of existing approaches to the formation of sales activity of the enterprise are explored. The objectives of the sales process of the enterprise are determined. The methods of optimization of sales process at the enterprise are analyzed.

Ключові слова: збут, збутова діяльність, принципи збутової діяльності, функиій збутової діяльності, uiлi npouecy збуmy.

Key words: sales, sales activity, sales activity principles, functions of sales activities, goals of the sales process.

\section{ПОСТАНОВКА ПРОБЛЕМИ}

На нинішньому етапі розвитку світового господарства, коли якість продукції є обов'язковою, але не достатньою умовою ринкового успіху, особливого значення набуває збут. Саме від зовнішньо логістики залежить сьогодні успішність компанії на ринку, оскільки формат доставки товару до споживача формує імідж поста- чальника в очах клієнта, що, в свою чергу, впливає на бажання останнього продовжувати співпрацю в майбутньому. 3 огляду на це, проблема розробки збутової діяльності перетворюється сьогодні на одну 3 ключових для підприємства, оскільки у процесі вибору оптимальних каналів розподілу продукції, компанія повинна максимально знизити витрати та якнайповніше за- 
довольнити потреби споживачів, підвищивши тим самим рівень конкурентоспроможності як на внутрішньому, так і на зовнішньому ринках. 3 огляду на це, актуальним $є$ дослідження особливостей розробки та реалізації збутової діяльності як одного з основних інструментів підвищення ефективності роботи підприємств, що $є$ учасниками міжнародних економічних відносин.

\section{АНАЛІЗ ОСТАННІХ ДОСЛІДЖЕНЬ І ПУБЛІКАЦІЙ}

Проблеми формування та реалізації збутової діяльності досліджували у своїх роботах Г.Г. Абрамішвілі, Б. Берман, Ю.П. Васильєв, В.Г. Виноградов А.М. Гвішіані, В.Г. Герасимчук I.M. Герчикова, Є.П. Голубков C.I. Гончарук, П. Кінгстон, Ф. Котлер, Ж.Ж. Аамбен, О.Е. Кузьміним, В.Я. Кардашем, Б. Міллером, А.Ф. Павленко, В.С. Пономаренком, П.Г. Перервою, I.А. Решетниковою, I.В. Семеняк, Х. Швальбе, Аж.Р. Евансом та ін. Проте особливості формування збутової діяльності підприємств-суб'єктів зовнішньоекономічної діяльності $\epsilon$ недостатньо дослідженими, що і обумовило вибір теми статті.

\section{ФОРМУЛЮВАННЯ ЦІЛЕЙ СТАТТІ} (ПОСТАНОВКА ЗАВДАННЯ)

Метою даної статті $€$ дослідження особливостей збутової діяльності підприємства - імпортера.

Завданнями виступають:

- визначення сутності поняття "збутова діяльнісь";

- дослідження принципів розробки збутової діяльності підприємства, що здійснює зовнішньоекономічну діяльність;

- аналіз існуючих підходів до формування збутової діяльності підприємства.

\section{ВИКЛАД ОСНОВНОГО МАТЕРІАЛУ} ДОСЛІДЖЕННЯ

Значна увага, яка протягом останніх років приділяється в науковій літературі проблемам ефективного збуту, обумовила існування значної кількості тлумачень таких понять, як "збут", "збутова діяльність". Правомірним вважаємо визначення Коноплева В.Т., який трактує збут як систему відносин у сфері товарно-грошового обміну між економічно та юридично незалежними суб'єктами ринку, що мають комерційні інтереси. Збутову діяльність автор визначає як цілісний процес, що охоплює планування обсягу реалізації товарів із урахуванням рівня прибутку, що очікується, пошук і обрання найкращого партнера, проведення торгів, включаючи встановлення ціни відповідно до якості товару та інтенсивності попиту, виявлення й активне використання факторів, здатних прискорити збут продукції та збільшити прибуток від реалізації [1].

Майбогіна М.В. вважає, що збут - це розподіл товарів, який являє собою передачу права власності на товар у процесі його переміщення від виробника до споживача. Збутова діяльність у даному контексті розглядається як сукупність заходів щодо дослідження й аналізу кон'юнктури ринку, визначення обсягів збуту, вибору та управління каналами розподілу, організації транспортування, складування, управління запасами та обслуговування замовлень, що здійснюється 3 метою досягнення економічних результатів від реалізації продукції споживачам та створення позитивного іміджу підприємства на ринку [2].

Узагальнюючи представлені підходи, можна зробити висновок, що збут доцільно трактувати суто як процес передачі товару від виробника до кінцевого споживача.

Збутова діяльність підприємства базується на комбінуванні внутрішніх (збутові підрозділи фірми; служба сервісу; фірмові магазини) та зовнішніх (фірми, що забезпечують перевезення; посередники та іх склади) елементів. Основними функціями системи товароруху $є$ оброблення замовлень покупця, технічний контроль виробів, одержаних від постачальників, формування партій товарів на замовлення покупців, зберігання продукції, формування оптимальних транспортних партій, пакування продукції відповідно до вимог транспортних і складських служб, оформлення митних документів і страхування, відвантаження і контроль за рухом вантажів, обслуговування в процесі експлуатації. Ефективність збутової діяльності, в свою чергу, визначається швидкістю виконання замовлення, можливістю термінової поставки товарів на спеціальне замовлення, готовністю прийняти поставлений товар при виявленні дефектів і заміна у найкоротші строки якісним, забезпеченням різних за величиною партій відвантаження на бажання покупців, наявністю ефективних транспортних засобів, служби сервісу, складської мережі, достатній рівень запасів та гнучкість цін. На досягнення підприємства ефективності за кожним з визначених критеріїв, необхідним $€$ врахування факторів внутрішнього та зовнішнього середовища підприємства та адаптація процесів управління збутом до вимог ринку.

Зважаючи на те, що успішність збутової діяльності визначають одночасно фактори внутрішнього та зовнішнього середовища, у процесі тї формування необхідно враховувати низку принципів, основними серед яких $€$ принцип економічності, плановості, синергізму, системності та комплексності, соціальної відповідальності, стратегічної гнучкості та ефективності.

Принцип економічності передбачає формування збутової діяльності з найменшими витратами ресурсів, проте не в збиток його раціональності і результативності. Зіставлення різних варіантів результатів і витрат на управління дає відповідь про його економічність.

Принцип плановості акцентує увагу на тому, що зміни повинні бути підготовлені, керовані і направлені на досягнення поставленої мети. Принцип розуміє під собою встановлення на певні періоди напрямів і кількісних показників діяльності. План розглядається як комплекс економічних і соціальних завдань, які належить вирішити в майбутньому.

Принцип синергізму означає, що номенклатура товарів, що випускаються, і послуг повинна бути внутрішньо зв'язана і окремі товари і види послуг повинні доповнювати один одного. Цей принцип забезпечує широку економію на масштабах діяльності підприємства за рахунок взаємної підтримки різних товарних груп або сфер господарської діяльності.

Принцип системності та комплексності означає необхідність використання системного аналізу. У формуванні збутової діяльності помилкове рішення може звести нанівець всю діяльність збутової системи, привести до їі руйнування. Комплексність означає необхідність усестороннього охоплення всієї збутової системи, облік всіх напрямів, всіх сторін діяльності, всіх особливостей.

Принцип соціальної відповідальності. Як відомо, соціальна відповідальність формується за рахунок суспільних очікувань. Останнім часом суспільні очікування, адресовані бізнесу, значно змінилися, нині суспільству стало не байдуже, як компанія веде свою діяльність, чим вона при цьому керується і як вона розпоряджається своїми доходами. Організація вельми активно і відкрито повинна діяти в таких сферах, як охорона місця існування, охорона праці, охорона здоров'я, захист прав громадян і споживачів. Тобто частину своїх доходів повинна обертати в благо громадян і суспільства, i робити це відкрито, системно, масштабно і в актуальних напрямах. Така громадська думка безпосередньо впливає на репутацію, імідж і на конкурентні переваги й інвестиційну привабливість промислових підприємств. Відповідно збутової діяльності соціальна відповідальність передбачає побудову всіх процедур збутової діяльності, задовольняючих існуючим соціальним цілям, соціальним стандартам і формуючих позитивний імідж по відношенню до досліджуваного підприємства.

Принцип стратегічної гнучкості передбачає пристосування до спеціальних побажань клієнтів, що є мінли- 
вими та диверсифікованими у часі та просторі. Принцип стратегічної гнучкості передбачає, що збутова діяльність має адаптуватися до ринку та часу збуту, а стратегія збуту має мати кілька альтернативних варіантів.

Принцип ефективності - вимога до обраної збутової діяльності забезпечувати високу результативність (прибутковість) функціонування підприємства. Його кількісна визначеність може виражатися через показники результативності діяльності.

Узагальнення наведених вище принципів дає підстави стверджувати, що за умови їх врахування, збутову діяльність підприємства-суб'єкта зовнішньоекономічної діяльності можна охарактеризувати як сукупність управлінських і виробничих дій, спрямованих на організацію і здійснення комплексу збутових операцій по доведенню готової продукції споживачам відповідно до їх вимог.

Необхідність формування ефективної збутової діяльності пов'язана з бажанням продавців перерозподілити існуючи ризики 3ЕА. Виводячи збут за межі ринку тільки однієї країни, виробник має можливість звести до мінімуму коливання попиту, оскільки цикли ділової активності країн перебувають у різних фазах, а одні й ті ж самі товари перебувають на різних етапах життєвого циклу. Ще один фактор розподілу ризику за допомогою експорту полягає у тому, що виробник може знайти більше клієнтів, зменшуючи свою вразливість при втраті якого-небудь одного або кількох клієнтів. Таким чином, збутова діяльність підприємства-суб'єкта зовнішньоекономічної діяльності охоплює на сьогодні наступні функції:

1) організування інформаційного забезпечення про стан ринку, проведення маркетингових досліджень складання прогнозів збуту;

2) підписання договорів на постачання продукції;

3) вибір форм і методів збуту, організування системи розподілу;

4) створення комунікації та організування правового забезпечення;

5) організування сервісного та післяпродажного обслуговування.

У збутовій діяльності часто виникають проблеми, які можна поділити на загальні та специфічні. Ао загальних проблем відносять: недосконалість організаційної структури підприємства, відсутність кооперативних відносин між підрозділами і відсутність підприємницького свідомості у співробітників. Ао специфічним відносять такі проблеми: невідповідність структури збуту реальним вимогам ринку і критеріям стабільної діяльності, ізольованість діяльності служби збуту, перекладення обов'язків інших служб на відділ збуту, відсутність мотивації у співробітників служби збуту на вдосконалення і розвиток своєї діяльності, відсутність технології роботи з клієнтами.

Аля оптимізації процесу збуту може бути використана модель стратегічної оптимізації збуту, яка заснована на структурному дослідженні збутової діяльності підприємства і виявлення тенденцій розвитку системи збуту. Аослідження збутової діяльності підприємства проводиться на основі наступних показників: географія збуту виступає як показник масштабу охоплення каналів збуту, доступності товарів для споживачів; рентабельність продажів відношення чистого прибутку до чистого обсягом продажів, вираженого в грошових коштах.

Існує кілька цілей оптимізації процесу збуту на підприємстві:

- зміцнення позицій на існуючому ринку; ббуту;

- створення ефективної системи стимулювання

- розвиток товарного або корпоративного бренду;

- створення внутрішніх конкурентних переваг;

- вихід на нові ринки збуту;

- лідерство на існуючому ринку;

- збільшення рентабельності продажів;

- збереження позиції.
Виходячи з наведених вище цілей, можна виділити способи оптимізації процесу збуту:

- розробка методів стимулювання споживача, які будуть знижувати рентабельність продажів по мінімуму;

- реінвестиції прибутку в виробничу сферу підприємства з метою поліпшення якості продукції та технології виробництва;

- стимулювання менеджерів 3 продажу;

- активний маркетинг, спрямований на регіональних споживачів;

- реінвестування прибутку в розвиток бренду;

- стимулювання середнього менеджменту;

- максимізація прибутку за рахунок стимулювання середнього менеджменту і збільшення продажів;

- масовий маркетинг;

- максимізація прибутку за рахунок стимулювання середнього менеджменту і збільшення продажів;

- реінвестування прибутку у відкриття нових торгових центрів і представництв;

- пошук нових дистриб'юторів і дилерів;

- інвестиції в розробку нових технологій, які допоможуть знизити виробничі витрати;

- активний маркетинг, спрямований на залучення нових споживачів;

- раціональне використання наявних оборотних коштів;

- пошук найбільш вигідних партнерів, постачальників сировини;

- інвестиції в розробку нових технологій, які допоможуть знизити виробничі витрати;

- досягнення максимально ефективного положення і контроль основних показників [7].

Зарубіжна практика виробила значну кількість рекомендацій відносно того, як повинна бути побудована збутова діяльність на підприємстві. Проте методи, які використовуються в країнах із розвиненою ринковою економікою, вимагають певної адаптації до вітчизняних умов, оскільки збутова діяльність підприємства значною мірою визначається сукупністю зовнішніх та внутрішніх умов функціонування підприємства.

На сьогодні збутова діяльність досить часто розробляється на підприємствах, зокрема у економічно розвинених країнах, на основі принципів маркетингового підходу. Прийняття концепції маркетингу на підприємстві змінює методи, за допомогою яких досягаються цілі виробництва і збуту продукції. За рахунок інтеграції функції маркетингу у систему управління підприємством здійснюється більш глибоке і ефективне поєднання збуту із дослідженням ринкової ситуації, плануванням асортименту продукції, змінюється характер роботи, пов'язаної з реалізацією продукції. На перший план висуваються потреби та вимоги споживачів, а не виробника товару, виробник стає активним учасником збуту продукції завдяки глибокій взаємодії 3 працівниками торгівельних організацій, включається в перепідготовку персоналу відділу маркетингу.

3 іншого боку, працівники збутозабезпечуючих служб, завдяки тісній взаємодії з іншими підрозділами відділу маркетингу мають доступ до більш глибокої інформації про своїх клієнтів, що підвищує ефективність комерційних комунікацій в системі управління.

На сьогодні, в умовах загострення конкуренції, збутова діяльність повинна відповідати головним напрямкам господарської діяльності підприємства, забезпечувати такий зміст виробничої, збутової, складської, транспортної та іншої діяльності, при якій вчасно реалізовується продукція споживачеві. 3 огляду на це, вважаємо за доцільне розглянути і логістичний підхід до організування процесу збуту на підприємстві, бо логістика керується принципами раціонального управління товарно-матеріальним потоком, то необхідно створювати такі організаційні системи, які б відображали цей потік.

Інтеграція принципів логістики та маркетингу в організаційну структуру управління підприємством пе- 
редбачає зосередження функцій, пов'язаних із збутом виготовленої продукції у відділі маркетингу і логістики. Така структура створює широкі можливості логістичної оптимізації матеріального потоку на етапах дослідження ринкової ситуації, постачання матеріалів, сировини, а також на етапах розподілу, реалізації продукції споживачам та післяпродажного обслуговування. Побудова відділу маркетингу з використанням принципів логістики, на відміну від традиційних організаційних структур відділу маркетингу, дасть змогу забезпечити: підпорядкування процесу управління матеріальним і інформаційним потоком цілям і задачам маркетингу, системний взаємозв'язок процесу збуту з процесом постачання (в плані управління матеріальним потоком), системний зв'язок всіх функцій всередині відділу маркетингу і логістики.

Важливим елементом процесу реалізації збутової діяльності на підприємстві $є$ економічне оцінювання, що передбачає вирішення комплексу питань, пов'язаних 3 вибором і обгрунтуванням стратегічного напрямку збутової діяльності, визначенням показників для контролювання збутової діяльності, оцінюванням впливу факторів мікросередовища на дієвість системи управління збутовою діяльністю. Аомінантними факторами мікросередовища, які чинять вплив на збутову діяльність підприємств, є ставлення споживачів до торгової марки підприємства-виробника, майбутні наміри щодо купівлі, мотивація та поведінка під час купівлі (кількість, частота, з якої нагоди здійснюється купівля), ринок досліджуваного товару - місткість, насиченість, тенденції змін на ринку, товари-замінники та конкуренти.

Забезпечення реалістичності економічного оцінювання, пов'язаного з обгрунтуванням стратегічного напрямку збутової діяльності, а також визначення показників контролювання збутової діяльності значною мірою залежать від формування збутових витрат. У нових умовах господарювання виробники повинні дотримуватися найважливішого управлінського принципу керувати через витрати, натомість керувати витратами.

Ситуація, яка складається на вітчизняному ринку, вимагає від його учасників прийняття гнучких рішень щодо економічного оцінювання процесу розподілу та реалізації, а також всіх маркетингових операцій, які забезпечують збут. Розуміючи, що без розрахунку коштів на збут неможливо отримати прихильності до своєї марки у споживачів, виробникам продукції необхідно переглянути підходи до економічного оцінювання витрат збутової діяльності. Важливим моментом у визначенні теоретико-прикладних засад елементів системи управління збутовою діяльністю є дослідження інструментарію інформаційного та аналітичного забезпечення збутової діяльності.

\section{ВИСНОВКИ}

Таким чином, здійснене дослідження дало підстави стверджувати, що в умовах загострення конкуренції та стрімкого розвитку ринку збутова діяльність перетворюється на ключовий елемент ефективного функціо- нування підприємства на ринку. На сьогодні не існує однозначного трактування збутової діяльності, проте більшість дослідників погоджуються, що її доцільно визначати як комплекс заходів з організації та здійснення збуту на підприємстві. На сьогодні збутова діяльність на підприємстві $€$ частково інтегрованою з маркетинговими та логістичними процесами, на яких вона базується. Це дозволяє мінімізувати витрати підприємства та, на основі врахування побажань споживачів, підвищити рівень конкурентоспроможності продукції. Залежно від сфери діяльності та стадії розвитку підприємствам доцільно обирати той чи інший підхід до збутової діяльності.

\section{\ітература:}

1. Коноплев В.Т. Международный маркетинг. Аонецк: Юго-Восток, 2008. - 319 с.

2. Майбогіна Н.В. Організація і методика аналізу збутової діяльності промислового підприємства: дис. ... канд. екон. наук: 08.00.09-К.,2009-23 с.

3. Кредісов A.I. Березовенко С.М., Волошин В.В., Биков Г.М., Мазуренко В.П. Управління зовнішньоекономічною діяльністю: навч. посіб. для студ. екон. вузів і ф-тів. - K.: BIPA-P, 2002. - 544 с.

4. Маштабей В. Я. Экспортный маркетинг. - К.: Хвиля-Прес, 2005. - 220 с.

5. Огерчук Ю. В. Організування збутової діяльності підприємств: дис... канд. екон. наук: 08.06.01/ Національний ун-т "Аьвівська політехніка". - $\Lambda ., 2004$.

6. Пелішенко В.П. Маркетинговий менеджмент: навч. посібник. - К.: Центр навчальної літератури, 2003. - 200 с.

7. Кислий В.М., Біловодська О.А., Олефіренко О.М., Смоляник О.М. Цогістика: Теорія та практика: навч. посіб. - К.: Центр учбової літератури, 2010. - 360 с.

References:

1. Konoplev, V.T. (2008), Mezhdunarodnyiy marketing [International marketing], Yuho-Vostok, Donetsk, Ukraine.

2. Maibogina, N.V.(2009), Organization and method of analysis of sales activity of an industrial enterprise, Abstract of Ph.D. dissertation, Economy, Kyiv, Ukraine.

3. Kredisov, A.I. Berezovenko, S.M. Voloshin, V.V. Bykov, G.M. and Mazurenko, V.P. (2002), Upravlinnya zovnishnoekonomichnoyu diyalnistyu [Management of foreign economic activity], VIRA-R, Kyiv, Ukraine.

4. Mashtabey, V.Yu. (2005), Ekspoptnyy mapketynh [Export marketing], Khvylia-Ppes, Kyiv, Ukraine.

5. Ogerchuk, Y.V. (2004), "Organizing sales activity of the enterprises", Abstract of Ph.D. dissertation, Economy, Natsional'nyj un-t "L'vivs'ka politekhnika", Lviv, Ukraine.

6. Pelishenko, V.P. (2003), Marketynhovyy menedzhment [Marketing Management], Tsentr navchal'noi literatury, Kyiv, Ukraine.

7. Kisliy, V. M. Belovodskaya, O. A. Olefirenko, O. M. and Smoljanik, O. M. (2010), Lohistyka: Teoriya ta praktyka [Logistics: Theory and Practice], Tsentr navchal'noi literatury, Kyiv, Ukraine.

Стаття надійила до редакцї 01.11.2018 p.

\section{ПЕРЕАП ААТА}

\section{ВИААННЯ МОЖНА ПЕРЕАПААТИТИ З БУАЬ-ЯКОГО М ІСЯЦЯ!}

- ЧЕРЕЗ РЕААКЦІЮ (ТЕ. . 458-10-73);

- ЧЕРЕЗ АП "ПРЕСА"

(У КАТАИОЗІ ВИААНЬ УКРАЇНИ);

— ЧЕРЕЗ ПЕРЕАП ААТНI АГЕНТСТВА 